\author{
UNIVERSIDADE DE SÃO PAULO \\ FACULDADE DE FILOSOFIA, LETRAS E CIÊNCIAS HUMANAS \\ DEPARTAMENTO DE GEOGRAFIA \\ PROGRAMA DE PÓS-GRADUAÇÃO EM GEOGRAFIA FÍSICA
}

VIVIAN CRISTINA DIAS

PARÂMETROS MORFOMÉTRICOS E CORRIDAS DE DETRITOS: ÍNDICE DE SUSCETIBILIDADE E MAGNITUDE PARA BACIAS HIDROGRÁFICAS NA SERRA DO MAR

Tese de Doutorado

Versão Corrigida

São Paulo

Dezembro, 2021 


\author{
UNIVERSIDADE DE SÃO PAULO \\ FACULDADE DE FILOSOFIA, LETRAS E CIÊNCIAS HUMANAS \\ DEPARTAMENTO DE GEOGRAFIA \\ PROGRAMA DE PÓS-GRADUAÇÃO EM GEOGRAFIA FÍSICA
}

VIVIAN CRISTINA DIAS

\begin{abstract}
PARÂMETROS MORFOMÉTRICOS E CORRIDAS DE DETRITOS: ÍNDICE DE SUSCETIBILIDADE E MAGNITUDE PARA BACIAS HIDROGRÁFICAS NA SERRA DO MAR
\end{abstract}

Tese de doutorado apresentada ao Programa de PósGraduação em Geografia Física, do Departamento de Geografia da Faculdade de Filosofia, Letras e Ciências Humanas da Universidade de São Paulo como requisito para obtenção do título de Doutora em Ciências.

Área de concentração: Geografia Física.

Linha de Pesquisa: Estudos Interdisciplinares em Pedologia e Geomorfologia.

Agência de fomento: Fundação de Amparo à Pesquisa do Estado de São Paulo (FAPESP). Processos \#2018/08402-4 e \#2019/11223-7.

Orientadora: Profa. Dra. Bianca Carvalho Vieira. Supervisor no Estágio de Pesquisa no Exterior: Prof. Dr. Scott McDougall

\footnotetext{
Versão Corrigida

São Paulo

Dezembro, 2021
} 
Autorizo a reprodução e divulgação total ou parcial deste trabalho, por qualquer meio convencional ou eletrônico, para fins de estudo e pesquisa, desde que citada a fonte.

Catalogação na Publicação

Serviço de Biblioteca e Documentação

Faculdade de Filosofia, Letras e Ciências Humanas da Universidade de São Paulo

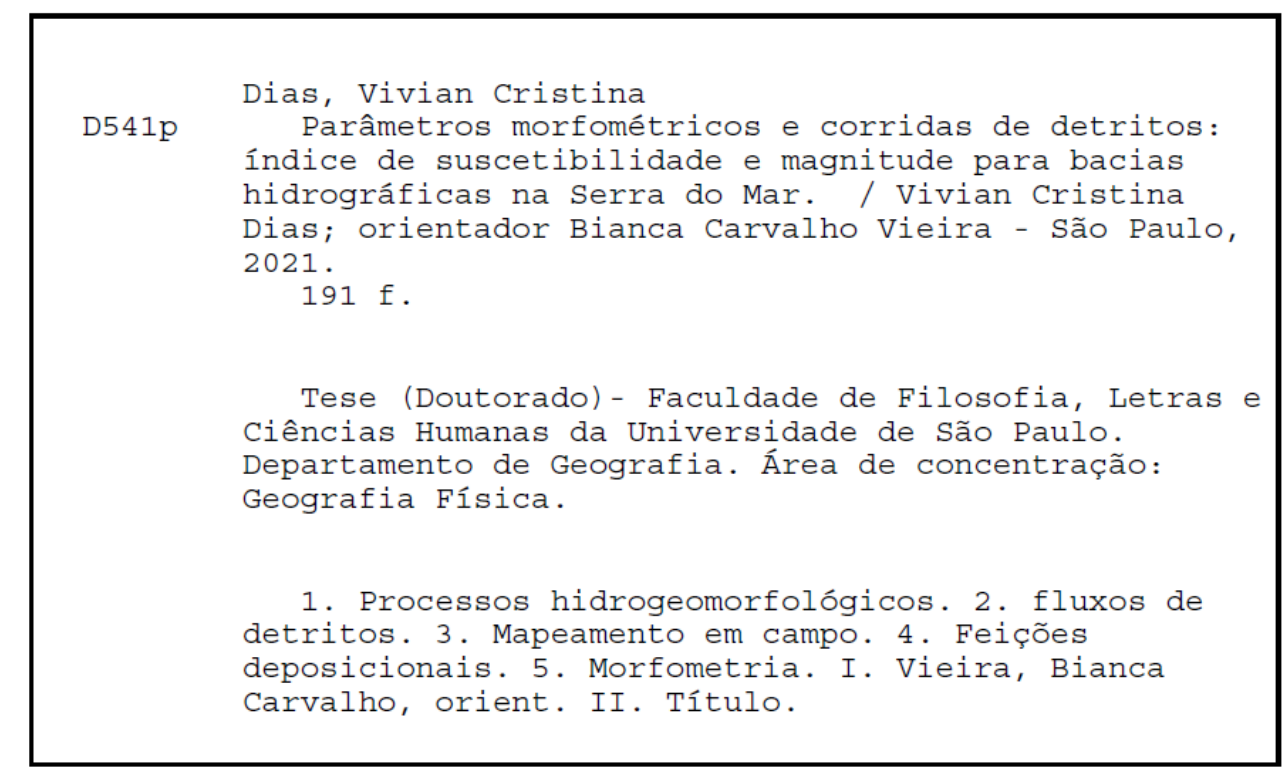




\section{ENTREGA DO EXEMPLAR CORRIGIDO DA DISSERTAÇÃO/TESE}

\section{Termo de Anuência do (a) orientador (a)}

Nome do (a) aluno (a): Vivian Cristina Dias

Data da defesa: 10/11/2021

Nome do Prof. (a) orientador (a): Bianca Carvalho Vieira

Nos termos da legislação vigente, declaro ESTAR CIENTE do conteúdo deste EXEMPLAR CORRIGIDO elaborado em atenção às sugestões dos membros da comissão Julgadora na sessão de defesa do trabalho, manifestando-me plenamente favorável ao seu encaminhamento e publicação no Portal Digital de Teses da USP.

São Paulo, 09/12/2021

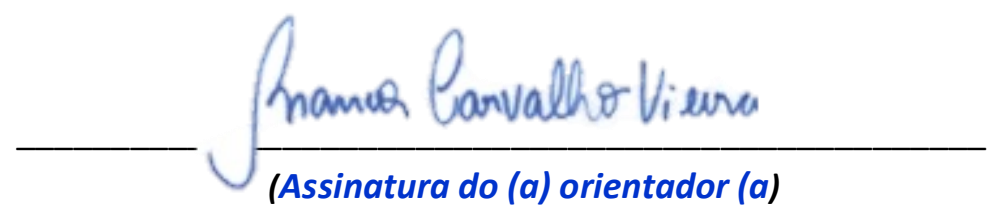




\title{
PARÂMETROS MORFOMÉTRICOS E CORRIDAS DE DETRITOS: ÍNDICE DE SUSCETIBILIDADE E MAGNITUDE PARA BACIAS HIDROGRÁFICAS NA SERRA DO MAR
}

\begin{abstract}
Tese de doutorado apresentada ao Programa de PósGraduação em Geografia Física, do Departamento de Geografia da Faculdade de Filosofia, Letras e Ciências Humanas da Universidade de São Paulo como requisito para obtenção do título de Doutora em Ciências.
\end{abstract}

Banca Examinadora

Profa. Dra. Bianca Carvalho Vieira (Orientadora)

Departamento de Geografia - Universidade de São Paulo

Prof. Dr. Claudinei Taborda da Silveira

Departamento de Geografia - Universidade Federal do Paraná

Prof. Dr. Fábio Augusto Gomes Vieira Reis

Instituto de Geociências e Ciências Exatas - Universidade Estadual do Estado de São Paulo

Profa. Dra. Maria Carolina Villaça Gomes

Departamento de Geografia - Universidade do Estado de Santa Catarina 
ḋ minha familia, $e$ aos pesquisadores brasileiros, que seguem fazendo muito com tão pouco... 


\section{AGRADECIMENTOS}

À minha orientadora, Bianca Carvalho Vieira, por todo o apoio, incentivo, ensinamentos, compreensão, carinho e amizade durante a realização desta pesquisa, que remontam desde a minha graduação.

À Fundação de Amparo à Pesquisa do Estado de São Paulo (FAPESP), pelo auxílio financeiro para a realização desta pesquisa, incluindo o estágio de pesquisa no exterior.

À Universidade de São Paulo, o Programa de Pós-Graduação em Geografia Física (PPGF) e à Comissão de Pós-Graduação da FFLCH, pelo auxílio para apresentação dos resultados parciais desta pesquisa em eventos científicos e suporte técnico.

To Alexandra Elbakyan, for providing free access to scientific journals, making communication more open and efficient, specially for students from developing countries like me.

Aos professores Claudinei Taborda da Silveira e Maria Carolina Villaça Gomes, pelos ensinamentos e ajuda em campo, e ao Professor Tiago Damas Martins, pelo aprendizado e suporte.

Ao amigo e parceiro no estudo das corridas de detritos Marcelo Fischer Gramani, pelos ensinamentos, amizade, contribuição e por ser uma referência ética e honesta.

I also would like to acknowledge Professor Scott McDougall, for accepted me as a visiting student in his research group, and all the colleagues of the Geohazards Research Team, highlighting Andrew Mitchel and Sophia Zubrycky, for kindly taken me to their study sites and helping me to improved my research. I must say that this thesis would never been made without your support. The monthly and weekly meetings of the Geohazards Team helped me a lot to develop this research, to see what was missing, and what I needed to improve to minimally correctly study debris flows with the limited data that I had. From the bottom of my heart, thank you for all. I know that this research is not much compared to what you do and are used to do, but know that for my reality of developing country, this research is very important, and I hope will help in the advance of the studies about debris flow in Brazil.

À minha família, que sempre esteve ao meu lado, me apoiando e me incentivando. Meus pais, Valter e Cristina, por me colocarem na escolinha quando eu pedi (tinha o que, 3 anos na época?) e sempre valorizarem meus estudos. Minha irmã Helen, pela amizade e amor incondicional, sempre me dando força e me fazendo sorrir nos momentos mais difíceis, mas também por puxar minha orelha quando necessário. Meu marido Fernando, pelo seu amor, carinho e paciência, especialmente nos momentos dificeis, e por sempre acreditar em mim quando eu mesma não acreditava mais. E meus filhos, Kylo e Valente, por seu amor puro, companheirismo e carinho.

Às amigas e companheiras científicas Rebeca, Ritinha e Camila, por tornarem a pós-graduação mais leve e descontraída para mim, sempre dispostas a me apoiar e me animar nos momentos de dificuldades.

Às amigas, Jessica e Thais, pela amizade e por sempre torcerem por mim ao longo desses mais de 10 anos de companheirismo e amizade que nasceu durante a graduação.

Também agradeço a todos os colegas que de alguma forma contribuíram para a realização desta pesquisa e que fizeram parte da minha vida durante este período de pouco mais de quatro anos.

A todos vocês, sou muito grata e compartilho aqui a importância de todos desde o processo seletivo para entrada no programa de pós-graduação até a conclusão desta etapa, deixando claro que, sem vocês, esta pesquisa não teria sido realizada, e que, portanto, ela também é de vocês.

E a você, que eventualmente esteja lendo este trabalho. Espero que ele contribua de alguma forma na realização do seu trabalho/pesquisa.

Muito obrigada a todos!!!

Que a Força esteja com vocês, sempre. 
"I don't know what happens next. I do not know what I am going to be or what I am going to learn but what I do know is this: life, all life, is about asking questions, not about knowing answers. It is yearning to see what is over the next hill that keeps all going. We must keep asking questions, yearning to understand. Even when we know we will never find the answers, we must keep on asking the questions".

Allie, Taken 
DIAS, V. C. (2021) Parâmetros morfométricos e corridas de detritos: índice de suscetibilidade e magnitude para bacias hidrográficas na Serra do Mar. Tese de doutorado. Programa de Pós-Graduação em Geografia Física, Universidade de São Paulo, 191p.

\section{RESUMO}

As corridas de detritos estão entre os movimentos de massa mais destrutivos, sobretudo, devido ao potencial de transporte por longas distâncias de grandes blocos e materiais diversos. Vários são os fatores condicionantes das corridas de detritos, com destaque a dinâmica das bacias hidrográficas e suas características morfométricas. No Brasil, são importantes os estudos a respeito das corridas de detritos devido tanto à recorrência do processo quanto ao número elevado de mortos e desabrigados e de perdas econômicas. Conforme o exposto, esta pesquisa teve como objetivo central a avaliação e validação de um índice de suscetibilidade e magnitude à ocorrência de corridas de detritos em bacias hidrográficas no Brasil. Para alcançar tal objetivo, as seguintes etapas foram definidas e cumpridas: (a) avaliar a ocorrência de corridas de detritos em diferentes áreas; (b) avaliar características predominantes dos depósitos oriundos de corridas de detritos, tais como localização, características dos materiais transportados e depositados etc.; (c) avaliar a relação entre morfometria e magnitude na definição da suscetibilidade das bacias às corridas de detritos. A pesquisa foi embasada na hipótese de que o índice suscetibilidade e magnitude a ocorrência de corridas de detritos proposto a partir da avaliação da ocorrência de corridas de detritos em Caraguatatuba/SP pode ser aplicado em diferentes áreas do país, podendo ser uma alternativa mais acessível para os municípios e órgãos gestores para a determinação de áreas suscetíveis. Os resultados da avaliação das ocorrências de corridas de detritos mostraram que o processo de arrastamento é parte fundamental da produção de sedimentos e no volume total produzido pela corrida de detritos. Da mesma forma, os depósitos avaliados em duas áreas distintas apresentaram similaridades, indicando um padrão de ocorrência do processo de corrida de detritos no Brasil. A avaliação das características morfométricas indicou parâmetros que podem ter contribuído para as diferenças entre as áreas avaliadas. Por fim, o índice de suscetibilidade e magnitude original criado a partir dos resultados em Caraguatatuba se mostrou ineficiente em classificar as bacias, sendo, então, recalibrado e alterado de acordo com os resultados obtidos nesta tese. Conforme o exposto, esta pesquisa contribuiu para o melhor entendimento da dinâmica das corridas de detritos no âmbito da geomorfologia e contribuir para os trabalhos de prevenção de desastres naturais em âmbito nacional a partir da avaliação morfométrica e classificação de áreas suscetíveis às corridas de detritos.

Palavras-chave: processos hidrogeomorfológicos, fluxos de detritos, morfometria, mapeamento em campo, feições deposicionais. 
DIAS, V. C. (2021) Morphometric parameters and debris flow: susceptibility and magnitude index to watersheds in Serra do Mar. Ph.D. Dissertation. Graduate Program in Physical Geography, University of São Paulo, 191p.

\begin{abstract}
Debris flows are one of the most destructive types of mass movement due to the transport potential in long distances of large boulders and other materials. Several conditioning factors are related to the occurrence of debris flows, highlighting the watershed's dynamics and their morphometric characteristics. In Brazil, the studies about debris flow are important due to the recurrence of the process and the high number of deaths and homeless, and economic losses. As explained above, the main goal of this research was the evaluation and validation of the index of magnitude potential and susceptibility to the occurrence of debris flow in watersheds in Brazil. To achieve this goal, it was established and accomplished the following methodological steps: (a) the evaluation of debris-flows occurrence in different areas; (b) the evaluation of main fan morphology characteristics; and (c) the evaluation of the relation between morphometric characteristics and magnitude in the definition of the susceptibility of the watersheds to debris flows The research is based in the hypothesis that the index of magnitude potential and susceptibility to the occurrence of debris flow proposed from the evaluation of debris-flow occurrence in Caraguatatuba/SP can be applied in different areas all over the country and can be an accessible alternative to the governments and managers to the determination of susceptible areas. The results of the evaluation of the past occurrences indicated the entrainment process as a fundamental part of the production of sediments and in the total volume produced by a debris flow. Furthermore, fan morphology in the different areas was similar, which can indicate a pattern in the occurrence of debris flows in Brazil. The analysis of the morphometric characteristics indicated parameters that could have influenced in the differences observed between the watersheds with and without recent occurrences of debris flows, but also in the similarities related to the magnitude of the processes in the affected areas. Lastly, the magnitude and susceptibility index created from the Caraguatatuba results did not present a good classification of the watersheds. As a result. As a result, the index was recalibrated and modified considering the new results obtained in this research. This research contributes to a better understanding of the debris-flow dynamics related to the geomorphology and future prevention actions to natural hazards in the country.
\end{abstract}

Keywords: hydrogeomorphological processes, debris flows, morphometry, field mapping, fan morphology. 


\section{LISTA DE FIGURAS}

Figura 2.1: Tipos de iniciação de corridas de detritos, segundo Takahashi (2007). .7

Figura 2.2: Esquema ilustrativo da deflagração de corridas de detritos conforme principais mecanismos observados no Brasil.

Figura 2.3: Diagrama esquemático ilustrando a distinção entre uma fração fina, que se mantém suspensa exclusivamente pelas forças de viscosidade e que, portanto, atua como parte do fluído (grão A) e uma fração grosseira que requer interação com outros grãos para se manter suspensa (grão B).

Figura 2.4: Perfil esquemático de uma corrida de detritos.

Figura 2.5: Inversão granulométrica em depósitos de corridas de detritos na Serra da Prata, Paraná (a) e em Caraguatatuba, São Paulo (b). 11

Figura 2.6: Depósito de corridas de detritos com marcação nas árvores, em Lillooet, no Canadá.

Figura 2.7: Representação das feições deposicionais de uma corrida de detritos (a e b) e depósitos de corridas de detritos observados em campo, no Paraná (c) e em São Paulo (d)...12

Figura 2.8: Localização da Serra do Mar e principais ocorrências (a) e perdas (b) relacionadas à ocorrência de movimentos de massa.

Figura 2.9: Ocorrência na Serra das Araras, em 1967. Escorregamentos deflagrados nas encostas (a); Destruição de rodovia Rio-São Paulo (b).

Figura 2.10: Desastre ocorrido em 1967, na cidade de Caraguatatuba/SP. Depósito de corridas de detritos (a); infraestruturas destruídas no centro urbano da cidade (b). 17

Figura 2.11: Principais ocorrências de corridas de detritos em Cubatão/SP, em 1985 (a e b); 1994 (c e d); e 2013 (e e f). (a): Destaque para os depósitos de corridas de detritos, no fundo dos vales; (b): Vista lateral, mostrando a grande quantidade de escorregamentos; (c): Região atingida pelos escorregamentos e corridas de detritos. Detalhe para as cicatrizes das corridas de detritos, que antingiram a refinaria no sopé da encosta; (d): Depósito de corridas de detritos localizado no Rio das Pedras; (e): Área atingida por corridas de detritos nas instalações da SABESP; (f): Carros arrastados pela corrida de detritos na Rodovia dos Imigrantes na ocasião do processo.

Figura 2.12: Movimentos de massa e enchentes ocorridos em 2008, no Vale do Itajaí. ........20

Figura 2.13: Desastre ocorrido em 2011, na Região Serrana do Rio de Janeiro. Depósito de corridas de detritos, em Teresópolis/RJ (a); Destaque para percurso realizado por corrida de detritos, na bacia do Rio Vieira, em Teresópolis/RJ (b).

Figura 2.14: Ocorrência na região da Serra da Prata. (a): Visão geral do depósito de corridas de detritos; (b): Detalhe para o tamanho dos blocos comparados à escala humana (círculo) e aos sedimentos finos depositados sobre os blocos (setas).

Figura 2.15: Ocorrência no município de Itaoca/SP, em 2014. (a): Residência destruída em porção central do município; (b): Depósito de corridas de detritos. 22 
Figura 2.16: Esquema explicativo da análise dendrocronológica. Os troncos das árvores atingidas pelas corridas de detritos sofrem alterações em seu interior, impactando o crescimento dos anéis internos do mesmo.

Figura 2.17: Árvores semi soterradas por corridas de detritos em Lillooet, Canadá. (a): árvore com troco enterrado e possivelmente com sinais de inclinação nos discos do tronco; (b): sequência de árvores enterradas por corridas de detritos.

Figura 2.18: Mapa derivado de medição por meio de radar para três eventos deflagradores de corridas de detritos, destacando a localização dos processos (círculos) e a localização dos medidores (triângulos).

Figura 2.19: Relação entre média anual de acumulação de sedimentos e o parâmetro Relação de relevo, para o rio Chenney, em Dakota do Sul, Estado Unidos

Figura 2.20: Relação entre índice de circularidade e magnitude de corridas de detritos em quatro bacias, em Caraguatatuba, São Paulo. O coeficiente de correlação obtido foi 0 ..........35

Figura 2.21: Relação entre Q x V de corridas de detritos. .....................................................36

Figura 2.22: Visualização da magnitude segundo segundo fator "volume". ..........................38

Figura 2.23: Classificação dos depósitos em quatro categorias: S, M, L e XL.......................38

Figura 3.1: Gráfico da relação entre acumulado de chuva $(\mathrm{mm})$ e tempo (horas), estipulando uma curva de limite crítico exponencial (em vermelho) para a determinação do volume de chuva necessário para a deflagração de eventos catastróficos.

Figura 3.2: Localização das áreas de estudo.

Figura 3.3: Localização da bacia Jacareí, de parte da região denominada Serra da Prata, no Estado do Paraná, abarcando os municípios de Morretes e Paranaguá.

Figura 3.4: Esquema da estrutura geológica do relevo do Paraná. 1: sedimentos cenozóicos da Planície Costeira e Plataforma Continental; 2: sedimentos cenozóicos da Bacia de Curitiba; 3: Grupos Bauru e Caiuá (Cretáceo); 4: Bacia de Santos; 5: derrames de basalto da Formação Serra Geral; 6: unidades paleozóicas e mesozóicas da Bacia do Paraná; 7: Formação Furnas; 8: embasamento pré-cambriano. Cidades - PAR: Paranaguá; CTB: Curitiba; PGR: Ponta Grossa; GUA: Guarapuava. Escarpas: SM: Serra do Mar; ED: Escarpa Devoniana; SG: Serra Geral.50

Figura 3.5: Mapa Geológico da Região da Serra da Prata.

Figura 3.6: Mapa Geomorfológico da Região da Serra da Prata. 52

Figura 3.7: Precipitações Médias Mensais na região da Serra da Prata durante o período de 1970-2000. Destaque para os meses de dezembro, janeiro e fevereiro, com os maiores valores.

Figura 3.8: Processo de corridas de detritos na bacia Jacareí. Depósito à jusante, compostos majoritariamente por material lenhoso, causando danos à rodovia (a). Depósito à montante, composto por grandes blocos. Destaque para a localização dos depósitos na bacia (b). .54

Figura 3.9: Escorregamentos deflagrados nas encostas da bacia Jacareí, na Serra da Prata, Paraná.

Figura 3.10: Depósito de corrida de detritos com blocos gigantes, na bacia do rio Tingindor. 
Figura 3.11: Deposição de materiais mais finos (a) e blocos menores (b), na planície da bacia.

Figura 3.12: Moradia atingida pelas corridas de detritos, com deposição de materiais finos e lenhosos (a); ponte sobre o rio Jacareí parcialmente destruída em Rodovia que liga Curitiba ao litoral (b)

Figura 3.13: Bacia Tingidor, sub-bacia da Jacareí, localizada na região da Serra da Prata, Paraná.

Figura 3.14: Escorregamentos nas encostas (a) que deflagraram as corridas de detritos (b) na bacia Tingidor.

Figura 3.15: Característica das corridas de detritos na bacia Tingidor, segundo setorização de Martins et al. (2012). Setor 1 (a), iniciação do processo; Setor 2 (b), deposição inicial com blocos gigantes; Setor 3 (c), deposição dos blocos menores em leque; e Setor 4 (d), deposição final com sedimentos finos e matéria orgânica.

Figura 3.16: Mapa de Localização do Município de Itaoca/SP.

Figura 3.17: Geologia simplificado dos encaixes do Maciço Itaoca. 61

Figura 3.18: Mapa Geológico de Itaoca. 61

Figura 3.19: Mapa Geomorfológico de Itaoca/SP

Figura 3.20: Precipitações Médias Mensais em Itaoca durante o período de 1970-2000. Destaque para os meses de dezembro, janeiro e fevereiro, com os maiores valores.

Figura 3.21: Processo de corridas de detritos em Itaoca. Escorregamentos deflagrados nas altas encostas deflagraram corridas de detritos nas drenagens, já saturadas pela chuva (a). Os detritos compostos por troncos e lama atingiram as porções mais baixas do relevo, causando dano à área urbana do município (b).

Figura 3.22: Matéria orgânica composta majoritariamente por troncos de árvores e galharia, que atingiram o centro urbano do município.

Figura 3.23: Bacia Guarda-mão I, no município de Itaoca, Estado de São Paulo. 66

Figura 3.24: Bacia Guarda-mão I. Corridas de detritos deflagradas pelo aporte de escorregamentos nas alta encostas (a). Detalhe para as cicatrizes dos escorregamentos e da erosão provocada pelas corridas de detritos (b).

Figura 3.25: Depósito de corridas de detritos na planície da bacia do Guarda-mão I, em Itaoca/SP.

Figura 3.26: Características das corridas de detritos na bacia Guarda-mão I, segundo setorização de Gramani; Martins (2015). Setor 1 (a), iniciação do processo, transporte inicial e erosão; Setor 2 (b), deposição inicial, com blocos de tamanho "gigante"; Setor 3 (c), deposição final, com sedimentos mais finos e matéria orgânica, e imagem aérea de 2019 da transição entre os setores 2 e 3 (d), com destaque para tamanho do carro, que serve como escala. 68

Figura 3.27: Bacia Gurutuba, localizada na região da Serra do Mar, no município de Itaoca, Estado de São Paulo.

Figura 3.28: Bacia Gurutuba. Grande quantidade de escorregamentos nas encostas (a). Detalhe para o tamanho das cicatrizes de escorregamentos (b). 70 
Figura 3.29: Bacia Guarda-mão II, localizada na região da Serra do Mar, no município de Itaoca, Estado de São Paulo.

Figura 4.1: Mapeamento dos depósitos na bacia Tingidor, na Serra da Prata/Paraná. ...........74

Figura 4.2: Ficha de mapeamento dos depósitos de corridas de detritos. ............................... 74

Figura 4.3: Depósitos de corridas de detritos na bacia Guarda-mão em 2014 (a) e a mesma área quase totalmente coberta pela vegetação em 2017 (b).

Figura 4.4: Mapeamento do "runout" das corridas de detritos e cicatrizes dos escorregamentos (a). No caso das corridas de detritos, foi considerado o trabalho erosivo realizado pelo fluxo ao passar pelo canal e a presença de depósitos ainda visíveis; no caso dos escorregamentos, foram considerados a ausência de vegetação e posição da encosta (b). .76

Figura 4.5: Verificação do volume das corridas de detritos no Japão. .78

Figura 4.6: Espacialização dos processos e relações consideradas para os cálculos de Volume de iniciação $\left(V_{i}\right)$, Volume de arrastamento $\left(V_{a}\right)$, Volume do depósito final $\left(V_{d p}\right)$ e Volume total $\left(\mathrm{V}_{\mathrm{t}}\right)$ das corridas de detritos

Figura 4.7: Comparação da área dos escorregamentos $\left(\mathrm{m}^{2}\right)$ (a). Predomínio de cicatrizes com área inferior a $1.500 \mathrm{~m}^{2}(\mathbf{b})$.

Figura 4.8: Inventário dos escorregamentos e seções mapeadas (a) e "Runout" da corrida de detritos (b) na bacia Tingidor.

Figura 4.9: Inventário dos escorregamentos e seções mapeadas (a) e "Runout" da corrida de detritos (b) na bacia Guarda-mão.

Figura 4.10: Panorama geral das corridas de detritos e feições encontradas nos depósitos na bacia Tingidor.

Figura 4.11: Visão geral dos depósitos das corridas de detritos mapeados na bacia Tingidor (a). Destaque para a deposição principal da corrida (b). .86

Figura 4.12: Feições encontradas no $\mathrm{P} 1$ da bacia Tingidor, na margem direita do canal.......87

Figura 4.13: Feições encontradas no P1 da bacia Tingidor, na margem esquerda do canal...87

Figura 4.14: Feições encontradas no $\mathrm{P} 2$ da bacia Tingidor, na margem direita do canal.......88

Figura 4.15: Feições encontradas no P3 da bacia Tingidor. 88

Figura 4.16: Feições encontradas no $\mathrm{P} 3$ da bacia Tingidor, na margem esquerda do canal...89

Figura 4.17: Feições encontradas no P4 da bacia Tingidor, na margem direita do canal.......89

Figura 4.18: Feições encontradas no P5 da Bacia Tingidor, em ambas as margens.

Figura 4.19: Piscina parcialmente destruída em moradia localizada no alto da encosta, na margem esquerda do rio, no P5. (a): imagem de 2011, logo após o evento, com sedimentos finos ainda presentes, indicando a altura do fluxo. (b): imagem recente da mesma área, já sem sedimentos finos e com canal e vale mais profundo, em comparação à época do evento. ...... 90

Figura 4.20: Feições encontradas no P6 da Bacia Tingidor, na margem direita. 91 
Figura 4.21: Moradia parcialmente destruída pela corrida de detritos na bacia Jacareí, com destaque em vermelho para a altura do fluxo. (a): imagem atual (2019). (b): registro de 2011.

Figura 4.22: Panorama geral das corridas de detritos e feições encontradas nos depósitos na bacia Guarda-mão I.

Figura 4.23: Visão geral dos depósitos de corridas de detritos mapeados na bacia Guarda-mão I (a). Vista aérea da área de deposição principal (b); Visão horizontal da área de deposição principal (c).

Figura 4.24:Feições encontradas no P1 da Bacia Guarda-mão I, com destaque para o barramento natural formado no canal.

Figura 4.25: Feições encontradas no P4 da Bacia Guarda-mão I, com destaque para a ilha de

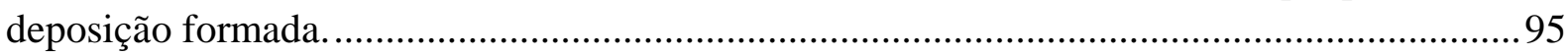

Figura 4.26: Feições encontradas no P2 da Guarda-mão I.................................................95

Figura 4.27: Feições encontradas no P3 da Guarda-mão I..................................................96

Figura 4.28: Espraiamento dos blocos na bacia Guarda-mão em área de abertura do relevo, em imagem de 2014, logo após o evento (a). Em imagem atual, de 2019, os blocos encontram-se parcialmente cobertos por restos de matéria orgânica após queimada realizada na área (b). Vista de jusate para montante. .96

Figura 4.29: Feições identificadas no $P 5$, na bacia Guarda-mão I, na margem esquerda do canal (a). Detalhe para visão frontal do bloco de tamanho muito grande (> 2 metros de diâmetro) (b).

Figura 4.30: Depósitos de corridas de detritos e feições identificadas, logo após o evento, em 2014 (a) e 5 anos depois, em 2019 (b). Apesar de possuírem ângulos diferentes, ambas as imagens foram tiradas no mesmo local, do mesmo depósito. As cores identificam os blocos na imagem de 2014 (sem vegetação) e na imagem de 2019 (com vegetação).

Figura 4.31: Vista aérea do depósito no P6, com destaque para o tamanho dos blocos em comparação ao carro.

Figura 4.32: Feições encontradas no P6 (a), com destaque para os sedimentos fino sobre os blocos $(\mathbf{b})$

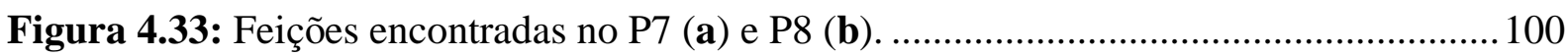

Figura 4.34: Feições encontradas no depósito no P7, na margem esquerda do rio................ 100

Figura 4.35: Veículo depositado no P8, em meio aos blocos e matéria orgânica.................. 100

Figura 4.36: Gráfico de velocidade e pico de vazão da bacia Tingidor............................... 102

Figura 4.37: Gráfico de velocidade e pico de vazão da bacia Guarda-mão I........................ 103

Figura 4.38: Cálculo de volume para as bacias Tingidor e Guarda-mão I........................... 104

Figura 4.39: Característica da chuva nas bacias Tingidor (a) e Guarda-mão I (b) obtidos a partir de estações pluviométricas próximas às duas áreas: 1) Distribuição de chuva multianual; 2) Distribuição de chuva mensal multianual; e 3) Distribuição mensal de chuva para o ano de 2011 
para a bacia Tingidor, com destaque para os volumes máximos de chuva para o mês de março (dados não disponíveis para a bacia Guarda-mão I)

Figura 4.40: Volume pluviométrico com base no Global Precipitation Measurement (GPM) da NASA para as áreas estudas no dia anterior ao evento (a e b) e no dia de deflagração dos processos (c e d). 107

Figura 4.41: Gráfico do volume total acumulado para as áreas de estudos de acordo com Global Precipitation Measurement (GPM) da NASA.

Figura 4.42: Depósitos de corridas de detritos em Montecito, Califórnia (a-c) e em Mocoa, Colômbia $(\mathbf{d}$ - f). 109

Figura 5.1: Sensor PRISM - Modo de observação Triplet. 117

Figura 5.2: Comparação entre drenagens de cartas topográficas (a e b) e drenagem extraída de MDE ALOS Palsar (c).... 118

Figura 5.3: Matrix de correlação entre os parâmetros morfométricos utilizando a correlação de Pearson. Na diagonal, encontra-se a curva de distribuição das variáveis. Na parte de baixo da curva de distribuição na diagonal encontram-se os gráficos de dispersão com linha de tendência. Na parte superior da curva de distribuição na diagonal encontram-se os valores das correlações. As correlações maiores que 0.800 (negativas ou positivas) estão destacadas, hieraquizadas e agrupadas por cores. 122

Figura 5.4: Boxplot dos parâmetros morfométricos considerando bacias com ocorrência e sem ocorrência de corridas de detritos.

Figura 5.5: Resumo da ocorrência de corridas de detritos na bacia Tingidor. 126

Figura 5.6: Resumo da ocorrência de corridas de detritos na bacia Guarda-mão I

Figura 5.7: Boxplot dos parâmetros da Tabela 5.4 categorizado por continente. 130

Figura 5.8: Diferença entre bacias com suprimento limitado (Sistema limitado pelo intemperismo) e ilimitado (Sistema limitado pelo transporte) de sedimentos e relação com ocorrência de corridas de detritos

Figura 6.1: Índice de potencial de magnitude e suscetibilidade 139

Figura 6.2: Índice de potencial de magnitude e suscetibilidade modificado a partir dos resultados obtidos e discutidos no Capítulo 5. 140

Figura 6.3: Classificação da magnitude das corridas de detritos em Caraguatatuba a partir da metodologia de Jakob (2005b). 


\section{LISTA DE TABELAS}

Tabela 2.1: Descrição e características dos principais mecanismos atuantes em uma corrida de detritos.

Tabela 2.2: Principais casos brasileiros, das regiões sul e sudeste, de ocorrência de corridas de detritos.

Tabela 2.3: Utilização de parâmetros morfométricos no estudo de corridas de detritos. 28

Tabela 2.4: Metodologia de classificação de magnitude de corridas de detritos proposta por Jakob (2005b).

Tabela 2.5: Categorias de avaliação de probabilidade de ocorrência de corridas de detritos utilizada na Columbia Britânica, Canadá.

Tabela 2.6: Fatores, classes, pesos (P), atributos e notas parciais (NP) utilizados para avaliação da suscetibilidade de uma área com relação a corridas de detritos.

Tabela 2.7: Intervalos propostos para determinação de suscetibilidade.

Tabela 2.8: Índices adimensionais e respectivos pesos.

Tabela 2.9: Classificação de magnitude de bacias afetadas por corridas de detritos em Caraguatatuba, SP.

Tabela 2.10: Índice de potencial de magnitude e suscetibilidade.

Tabela 2.11: Classificação do índice em 5 níveis

Tabela 2.12: Classificação das bacias segundo o índice de potencial de magnitude e suscetibilidade.

Tabela 2.13: Critérios de classificação de suscetibilidade à movimentos de massa da CPRM.

Tabela 3.1: Caracterização das corridas de detritos na sub-bacia do Rio Tingidor, Região da Serra da Prata..... .58

Tabela 3.2: Caracterização das corridas de detritos na bacia Guarda-mão I, em Itaoca. 68

Tabela 4.1: Identificação de evidências morfológicas de corridas de detritos na paisagem. ..73

Tabela 4.2: Resultados da área dos escorregamentos. 82

Tabela 4.3: Resultados para Pico de vazão (Q) e Velocidade (U) nas bacias Tingidor e Guardamão I.

Tabela 4.4: Resultados de Volume $\left(\mathrm{m}^{3}\right)$ para ambas as bacias. 104

Tabela 4.5: Classificação de magnitude com base em Jakob (2005a). 105

Tabela 4.6: Comparação do volume inicial $\left(\mathrm{m}^{3}\right)$ e final $\left(\mathrm{m}^{3}\right)$ de corridas de detritos em diferentes localidades.

Tabela 5.1: Parâmetros morfométricos mapeados 119

Tabela 5.2: Estatística descritiva geral dos parâmetros morfométricos. 120 
Tabela 5.3: Resultados dos parâmetros morfométricos específicados por bacias com e sem ocorrência de corridas de detritos.

Tabela 5.4: Parâmetros morfométricos mais utilizados para avaliação de áreas afetadas por corridas de detritos em diferentes áreas.

Tabela 6.1: Classificação de magnitude de corridas de detritos considerando apenas corridas de detritos com blocos.

Tabela 6.2: Resultados da aplicação do Índice de potencial de magnitude e suscetibilidade proposto por Dias (2017).

Tabela 6.3: Resultados da aplicação do Índice de potencial de magnitude e suscetibilidade modificado a partir dos resultados obtidos e discutidos no Capítulo 5 143

\section{LISTA DE EQUAÇÕES}

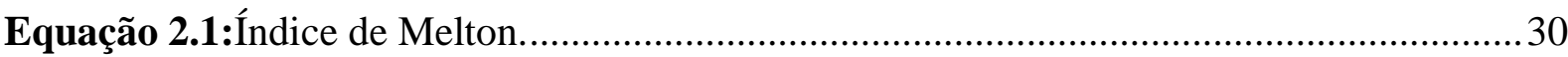

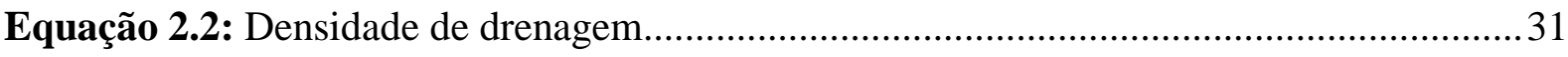

Equação 2.3: Hierarquia de drenagem (Shreve) ................................................................. 31

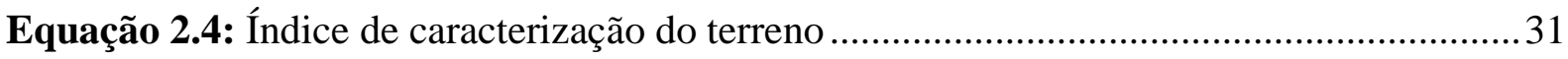

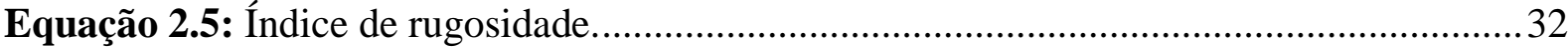

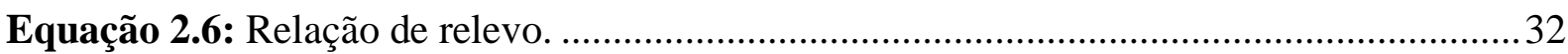

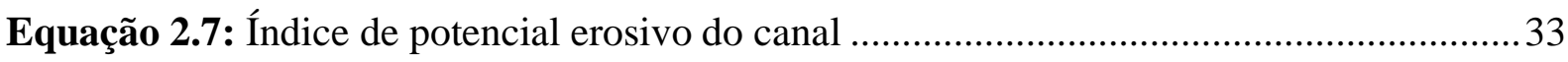

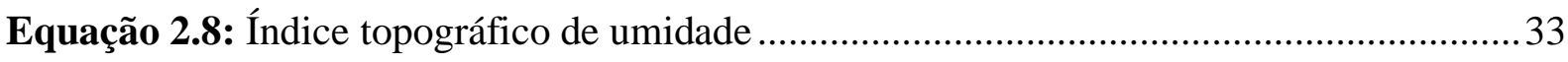

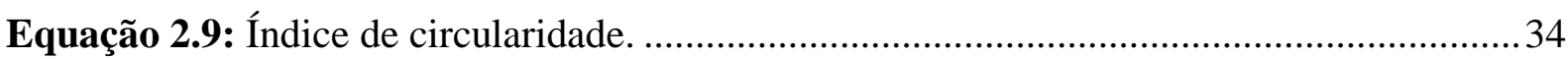

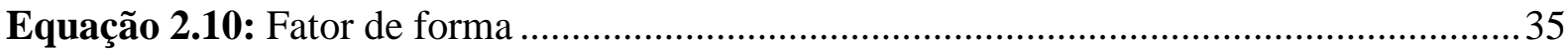

Equação 2.11: Relação empírica entre vazão de pico e volume de corridas de detritos.........36

Equação 4.1: Equação de Manning para cálculo de vazão de pico........................................76

Equação 4.2: Equação de Manning para cálculo da velocidade. ........................................... 76

Equação 4.3: Volume cicatrizes de escorregamentos. ...................................................... 77

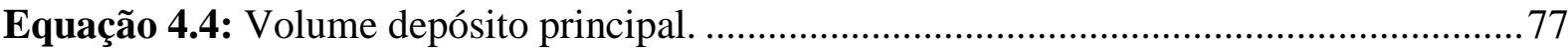

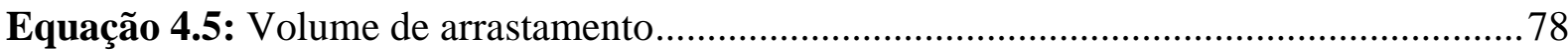




\section{LISTA DE SÍMBOLOS}

$\Delta \boldsymbol{A} \quad$ Amplitude altimétrica

$\Delta \boldsymbol{P l}$ Gradiente altimétrico do perfil longitudinal

A Área da bacia

A25 Área da bacia $>25^{\circ}$

Ac Ângulo do Canal

Cb Comprimento da bacia

Cc Comprimento dos canais

Cfa Clima subtropical úmido, com verão quente

Cfb Clima subtropical mesotérmico com verão ameno

Dd Densidade de drenagem

Hd Hierarquia de drenagem

Ic Índice de circularidade

Ir Índice de rugosidade

M Índice de Melton

PI Perfil Longitudinal

Q Pico de vazão

Rr Relação de relevo

SPI Índice de potencial erosivo

TCI Índice de caracterização do terreno

TWI Índice topográfico de umidade

U Velocidade

V Volume

$V_{\boldsymbol{a}} \quad$ Volume de arrastamento

$V_{\boldsymbol{c}}$ Volume cicatrizes de escorregamento

$V_{d p} \quad$ Volume do depósito principal

$V_{i} \quad$ Volume inicial

$V_{t} \quad$ Volume total 


\section{LISTA DE SIGLAS}

ALOS Advanced Land Observing Satellite

ASF Alaska Sattelite Facility

AVNIR-2 Advanced Visible and Near-Infrared Radiometer type 2

CEMADEN Centro Nacional de Monitoramento e Alerta de Desastres Naturais

COPEBRÁS Companhia Petroquímica Brasileira

CPRM Companhia de Pesquisa de Recursos Minerais

DAEE Departamento de Águas e Energia Elétrica

DAM3D Dynamic Analysis in 3D

DRM Departamento de Recursos Minerais

EMPLASA Empresa Paulista de Planejamento Metropolitano S/A

ESRI Environmental Systems Research Institute

GIS Geographic Information System

GPM Global Precipitation Measurement

GPmorfo Grupo de Pesquisas de Processos Morfodinâmicos e Ambientais

GPR Ground-penetrating radar

IBGE Instituto Brasileiro de Geografia e Estatística

IDHM Índice de Desenvolvimento Humano Municipal

IGc Instituto Geográfico e Cartográfico

IPT Instituto de Pesquisas Tecnológicas do Estado de São Paulo

ITCG Instituto de Terras, Cartografia e Geologia do Paraná

MDE Modelo Digital de Elevação

NASA National Aeronautics and Space Administration

PALSAR Phased Array L-band Synthetic Aperture Radar

PIB Produto Interno Bruto

PRISM Panchromatic Remote-sensing Instrument for Stereo Mapping

RAMMS Rapid Mass Movement Simulations

RPBC Refinaria presidente Bernardes Cubatão

SABESP Companhia de Saneamento Básico do Estado de São Paulo

SIG Sistema de Informação Geográfica 
SRTM Shuttle Radar Topography Mission

USDA United States Department of Agriculture

USGS United States Geological Survey 


\section{SUMÁRIO}

1. INTRODUÇÃO

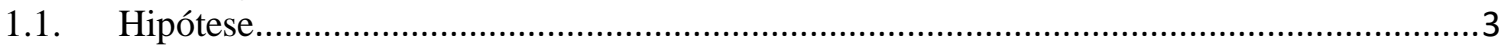

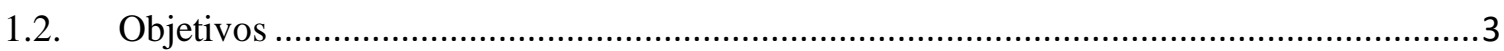

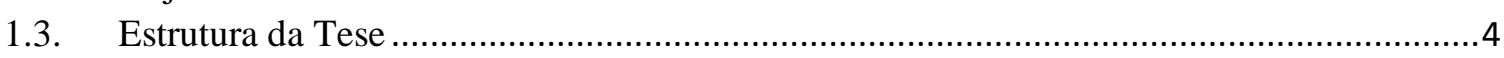

2. REVISÃO TEÓRICA SOBRE CORRIDAS DE DETRITOS.....................................5

2.1. Corridas de detritos: conceitos e fatores condicionantes ...............................................

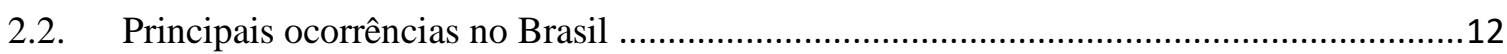

2.3. Métodos de previsão e avaliação de suscetibilidade e frequência ......................................24

2.4. Classificação de magnitude e hierarquização de bacias hidrográficas a partir de parâmetros morfométricos

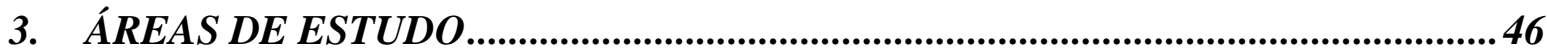

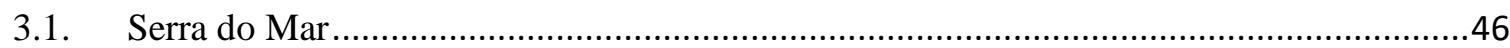

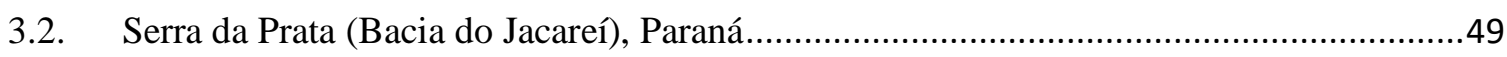

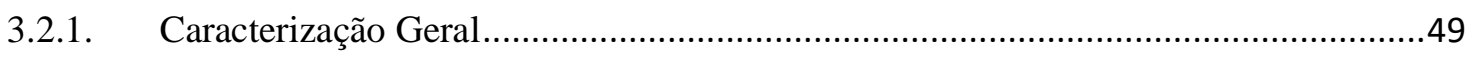

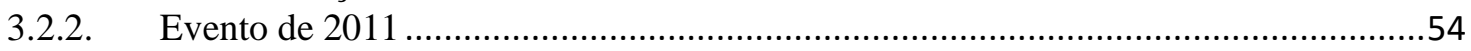

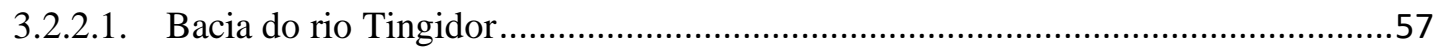

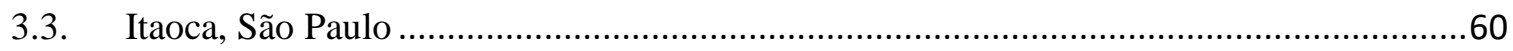

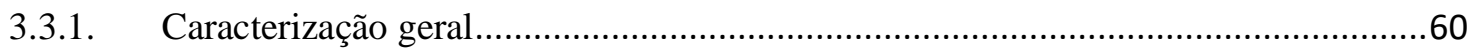

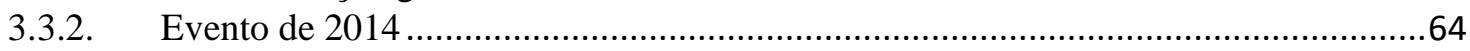

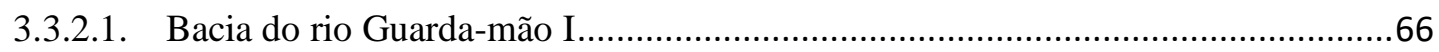

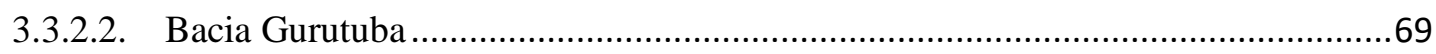

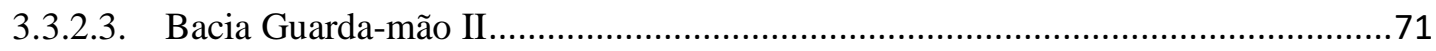

4. CARACTERIZAÇÃO DAS CORRIDAS DE DETRITOS NA SERRA DA PRATA (2011) E EM ITAOCA (2014): MORFOLOGIA DOS DEPÓSITOS E MAGNITUDE...72

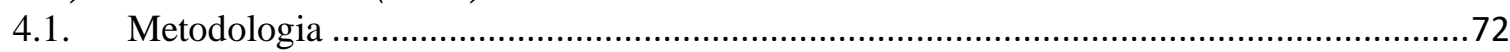

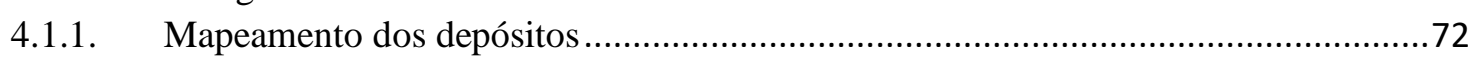

4.1.2. Inventário de corridas de detritos (runout) e escorregamentos (cicatrizes) ................75

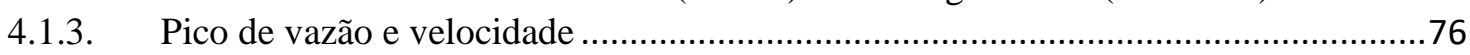

4.1.4. Estimativa de volume e determinação da magnitude ..............................................77

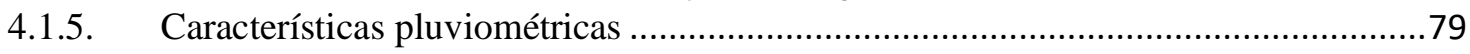

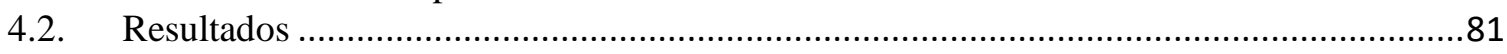

4.2.1. Características das corridas de detritos e dos escorregamentos .................................81

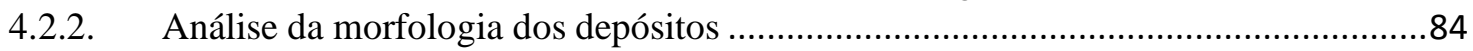

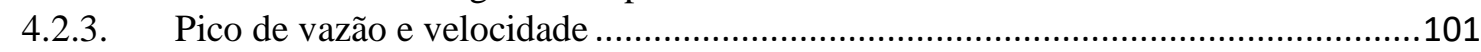

4.2.4. Estimativa de volume de arrastamento e potencial magnitude .................................103

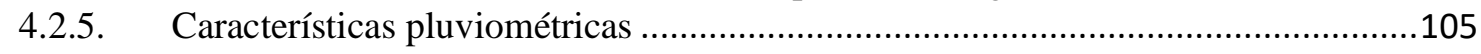

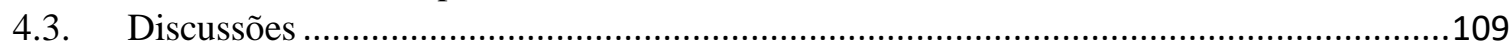

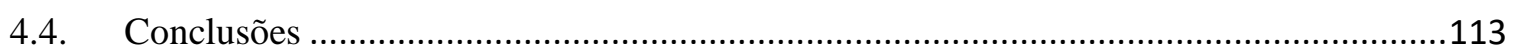



CORRIDAS DE DETRITOS .................................................................................115

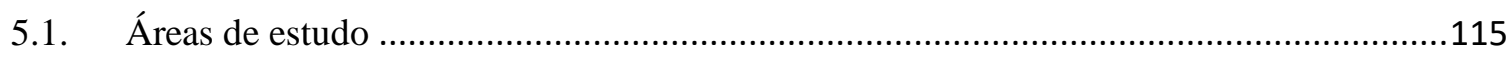

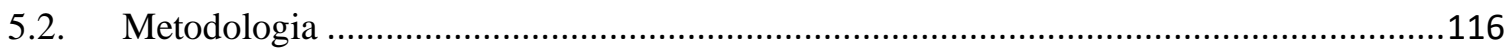

5.2.1. Preparação da base de dados..........................................................................116

5.2.2. Parâmetros morfométricos e análise estatística ......................................................118

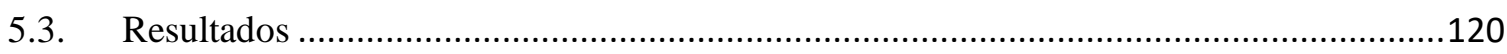

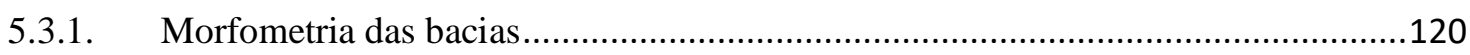

5.3.2. Relação com a ocorrência de corridas de detritos ....................................................123

5.3.3. Relação com a magnitude das ocorrências..............................................................126

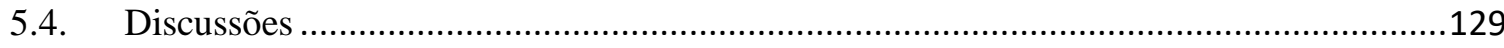

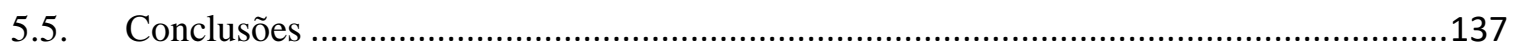

6. ÍNDICE MORFOMÉTRICO DE CLASSIFICAÇ̃̃O DE BACIAS HIDROGRÁFICAS À OCORRÊNCIA DE CORRIDAS DE DETRITOS: AVALIAÇÃO DE APLICABILIDADE EM AÇÕES DE PREVENÇÃO E MITIGAÇÃO ......................138

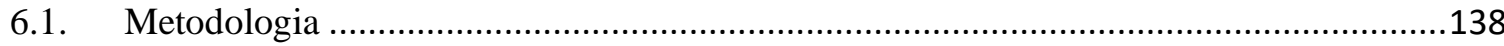

6.1.1. Índice original proposto por Dias (2017) ……………………………………......138

6.1.2. Índice modificado (2021)..............................................................................

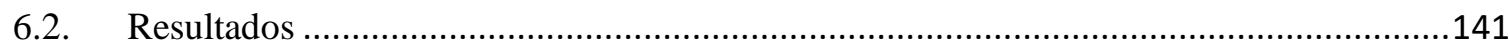

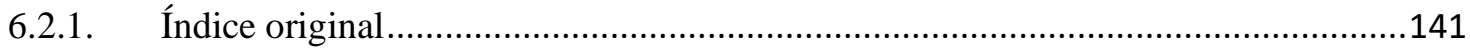

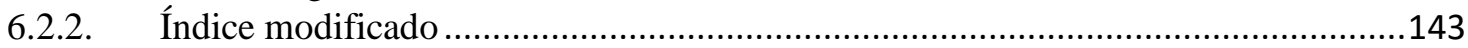

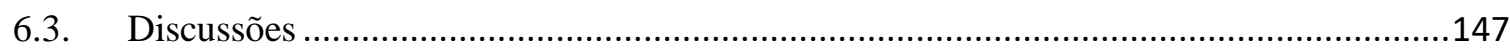

6.4. Conclusões ………………………………………………………………………... 150

7. CONSIDERAÇÕES FINAIS E RECOMENDAÇÕES ……....................................151

7.1. Resumo das principais contribuições da tese ................................................................151

7.2. Implicações para avaliação da suscetibilidade e desafios da pesquisa ............................152

7.3. Recomendações para trabalhos futuros ......................................................................153

REFERENCIAS 


\section{INTRODUÇÃO}

As corridas de detritos estão entre os tipos de movimentos de massa com maior potencial destrutivo, dada à sua capacidade de transporte, por longas distâncias, de sedimentos com grande variação granulométrica, alcançando as áreas mais planas e urbanizadas do relevo (JAKOB; HUNGR, 2005; TAKAHASHI, 2007).

O processo é deflagrado devido ao aporte de água em ambientes com grande disponibilidade de materiais para transporte, onde à perda de atrito interno entre as partículas do solo devido ao excesso de água, gera um fluxo visco-plástico de caráter não-newtoniano ${ }^{1}$, sendo mobilizado, sobretudo, pela gravidade (GUIDICINI; NIEBLE, 1984; SELBY, 1993). Trata-se de um processo de abrangência mundial, não estando restrito à uma determinada faixa climática, e sim, às características geomorfológicas específicas da região atingida, mas sendo comum sua ocorrência em áreas com relevo montanhoso (COSTA, 1984; ZNAMESNSKY, 2001).

Dada às características climáticas, geológicas e geomorfológicas em algumas regiões do Brasil, tais processos são frequentes e de alta magnitude causando danos às infraestruturas urbanas, grande número de mortes e desabrigados, além deperdas econômicas e sociais (KANJI et al., 2017; VIEIRA; GRAMANI, 2015). Dentre as ocorrências nacionais, se destacam o evento em Caraguatatuba (SP) (CRUZ, 1974; DE PLOEY; CRUZ, 1979) e na Serra das Araras (RJ) (JONES, 1973), em 1967; em Cubatão (SP) (JICA, 1991; KANJI; CRUZ; MASSAD, 2008), em 1985; no Rio de Janeiro (RJ) (FERNANDES et al., 2004; GOMES et al., 2013, 2008), em 1996; em Santa Catarina (FARIA et al., 2008; TOMAZZOLI; FLORES; BAUZYS, 2009), em 2008; e na Região Serrana do Rio de Janeiro (AVELAR et al., 2013; LIMA; FERNANDES; VARGAS JUNIOR, 2020) e Serra da Prata, no Paraná (MARTINS et al., 2012; PICANÇO et al., 2016; SILVEIRA et al., 2013; ZAI et al., 2017), em 2011; na Rodovia dos Imigrantes, em na Serra do Mar Paulista (ALTRICHTER; GRAMANI, 2014), em 2013; e recentemente em Itaoca (SP), em 2014 (BROLLO et al., 2015; GRAMANI; MARTINS, 2016; MATOS et al., 2018).

A identificação de áreas suscetíveis à ocorrência de corridas de detritos é uma etapa fundamental para a mitigação de novas ocorrências (JAKOB, 2005a). Destaca-se também que muitas das áreas já atingidas pelos processos possuem indícios de ocorrência de eventos pretéritos, que não são, no entanto, identificados pelo poder público e pela população.

\footnotetext{
${ }^{1}$ De forma simplificada, é aquele que não possui viscosidade bem definida.
} 
Diversas são as ferramentas de prevenção das corridas de detritos, com destaque para a avaliação morfométrica, limiares críticos de chuvas deflagradoras e construção de barreiras físicas, a fim de diminuir o dano potencial e limitar ou reduzir o alcance dos materiais transportados (BORGA et al., 2014; HUEBL; FIEBIGER, 2005; JAKOB; OWEN; SIMPSON, 2012).

No Brasil, o método mais utilizado para a previsão e o monitoramento de áreas suscetíveis é a avaliação dos volumes pluviométricos e dos limites críticos para a deflagração de movimentos de massa, neste caso, corridas de detritos e escorregamentos. No entanto, no caso das corridas de detritos, por se tratar de um processo mais complexo, por envolver características específicas de bacias hidrográficas, com grande extensão desde do seu ponto de deflagração até o seu depósito final, a investigação a partir de limites críticos de chuva pode ser imprecisa, uma vez que a variabilidade espacial da chuva é maior do que a abrangência das redes de monitoramento pluviométrico (BORGA et al., 2014). Além disso, as áreas de interesse para ocorrência do processo no Brasil não possuem uma rede adequada de monitoramento contínuo. Soma-se a isso a indisponibilidade de um registro histórico capaz de indicar os limites críticos de chuvas deflagradoras de corridas de detritos.

Neste âmbito, a avaliação e a definição de áreas suscetíveis por meio da análise morfométrica das bacias, e a identificação de depósitos pretéritos do evento, são opções que vêm ganhando espaço em todo o mundo, tanto por serem de menor custo, quanto por sua praticidade, quando comparadas com outras técnicas.

A partir da avaliação das características morfométricas das bacias, é possível verificar a sua propensão à processos hidrogeomorfológicos, potencial de escoamento, transporte e produção de sedimentos (AUGUSTO FILHO, 1993; CERRI et al., 2018; CHEN; YU, 2011; DE SCALLY; SLAYMAKER; OWENS, 2001; DIAS; VIEIRA; GRAMANI, 2016; GOMES, 2016; ILINCA, 2021; JAKOB, 1996; KOVANEN; SLAYMAKER, 2008; LIMA; FERNANDES; VARGAS JUNIOR, 2020; PICANÇO et al., 2016; PORTILLA; CHEVALIER; HÜRLIMANN, 2010; SIMONI; MAMMOLITI; BERTI, 2011a; VANDINE, 1985; VIEIRA et al., 1997; ZUBRYCKY et al., 2021)

Estas características, quando avaliadas em conjunto com informações sobre as corridas de detritos e seu alcance e magnitude, podem fornecer indicar e sugerir a influência de determinados parâmetros morfométricos na dinâmica destas corridas de detritos. Alguns autores propuseram, inclusive, índices com base na morfometria e ponderação de atributos para a avaliação da suscetibilidade de bacias às corridas de detritos (DIAS, 2017; KANJI; 
GRAMANI, 2001). No entanto, tais metodologias se referem às ocorrências em bacias específicas, não sendo testadas ainda em outras áreas.

\subsection{Hipótese}

A partir da relação entre os parâmetros morfométricos e as corridas de detritos é possível estabelecer particularidades de uma determinada bacia hidrográfica que podem favorecer a ocorrência do processo e estimar o seu alcance e magnitude. Neste sentido, tem-se a hipótese que seja possível aplicar um mesmo índice a partir de parâmetros morfométricos em áreas cujas características gerais (relevo escarpado; abundante fonte de água/volume de chuva) favoreçam a deflagração de corridas de detritos, podendo, a partir de sua classificação, determinar o potencial de magnitude que as ocorrências nestas áreas poderão ter. Neste sentido, a pergunta central deste Projeto é: $\mathbf{E}$ possível definir um índice de suscetibilidade e magnitude à ocorrência de corridas de detritos para a Serra do Mar a partir de parâmetros morfométricos? A partir daí a hipótese da pesquisa baseia-se em uma relação direta entre determinadas características morfométricas de uma bacia e a magnitude de corridas de detritos, sendo possível, portanto, classificá-las quanto ao potencial de magnitude do processo e estimar seu possível potencial destrutivo com base em seu alcance.

\subsection{Objetivos}

O objetivo central desta pesquisa foi a avaliação e a validação de um índice de suscetibilidade e magnitude à ocorrência de corridas de detritos em bacias hidrográficas no Brasil.

Para tal, os seguintes objetivos específicos foram estabelecidos:

- Avaliar a ocorrência de corridas de detritos em diferentes áreas na Serra do Mar, considerando volume $\left(\mathrm{m}^{3}\right)$, pico de vazão $\left(\mathrm{m}^{3} / \mathrm{s}\right)$, velocidade $(\mathrm{m} / \mathrm{s})$, e morfologia;

- Avaliar características predominantes dos depósitos oriundos de corridas de detritos, tais como localização, características dos materiais transportados e depositados etc.;

- Avaliar a relação entre a morfometria e a magnitude na definição da suscetibilidade das bacias às corridas de detritos considerando as bacias afetadas por corridas de detritos recentes e as características do evento, e comparação com as bacias sem ocorrências recentes. 


\subsection{Estrutura da Tese}

A presente tese de doutorado está estruturada em 7 Capítulos principais, nos quais os resultados são apresentados e descritos separadamente, em formato de "artigo", estrutura amplamente utilizada no exterior e com a qual a autora teve contato durante o estágio de pesquisa no exterior, facilitando a escrita e posterior publicação dos resultados da pesquisa, sendo eles: Introdução (1), contendo hipótese e objetivos; Revisão teórica sobre corridas de detritos (2), abordando os principais conceitos a respeito das corridas de detritos e métodos de avaliação de suscetibilidade e frequência; Áreas de estudo (3), onde são apresentadas as áreas selecionadas e descritas as ocorrências de corridas de detritos; Caracterização das corridas de detritos na Serra da Prata (2011) e em Itaoca (2014): morfologia dos depósitos e magnitude (4), onde são descritos os principais procedimentos realizados e resultados referentes à caracterização detalhada das ocorrências; Avaliação da relação entre morfometria e o processo de corridas de detritos (5), onde são descritos os procedimentos realizados para mapeamento dos parâmetros morfométricos, sua análise e resultados; Índice morfométrico de classificação de bacias hidrográficas à ocorrência de corridas de detritos: avaliação de aplicabilidade em ações de prevenção e mitigação (6), que trata da aplicação do índice de potencial de suscetibilidade e magnitude e resultados. Por fim, nas Considerações finais e recomendações (7), são apresentadas as principais contribuições da pesquisa, suas implicações na avaliação da suscetibilidade, principais desafios desta pesquisa e recomendações para trabalhos futuros. 


\section{REVISÃO TEÓRICA SOBRE CORRIDAS DE DETRITOS}

Este capítulo visa proporcionar uma revisão da literatura a respeito das corridas de detritos, destacando suas características fundamentais, formas de deflagração e identificação. Também são aqui descritas as principais ocorrências de corridas de detritos no Brasil, com destaque para os danos sociais e econômicos causados. A avaliação morfométrica é apresentada como um dos principais métodos utilizados pelas literaturas internacional e nacional na avaliação da suscetibilidade e da magnitude de corridas de detritos. Por fim, são evidenciadas formas de classificação da suscetibilidade de áreas afetadas por corridas de detritos utilizando a magnitude e os parâmetros morfométricos.

\subsection{Corridas de detritos: conceitos e fatores condicionantes}

As corridas de detritos são definidas como fluxos de solo, rocha ou matéria orgânica de caráter não-newtoniano e induzidos pela gravidade. Sua ocorrência está relacionada à perda de atrito entre as partículas de solo em presença de excesso de água, podendo ocorrer em encostas e drenagens (COSTA, 1984; SELBY, 1993; TAKAHASHI, 1991). Segundo a classificação de movimentos de massa de Varnes (1978), que utiliza como critério o tipo de movimento e o material transportado, as corridas de detritos estão classificadas em movimentos do tipo "fluxo/corridas" de matérias do tipo "predominantemente grosseiros". Hungr et al. (2001), com enfoque nas diferentes tipologias de fluxos, propôs uma nova classificação unindo as duas anteriores, buscando melhorar a definição dos diferentes tipos de movimentos de massa do tipo "fluxo", além de esclarecer especificidades de cada um, evitando incoerências quanto à identificação dos processos. Por tratar-se de uma classificação abrangente e por se pautar em duas classificações consagradas na literatura, optou-se pela utilização dos critérios propostos por Hungr et al. (2001) no que se refere à definição do processo de corridas de detritos. Os autores compreendem que as corridas são definidas como "um fluxo saturado de detritos com canal estabelecido e com velocidade extremamente rápida".

Considerando o seu ambiente de ocorrência, também é possível classificar as corridas de detritos em dois tipos específicos: Lahars e Tillflows. As corridas de detritos do tipo Lahars ocorrem próximas a zonas de erupção vulcânica, sendo formadas a partir da mobilização de cinzas vulcânicas depositadas nas encostas subjacentes; já as corridas denominadas Tillflows ocorrem em ambiente glacial, geradas a partir do derretimento de geleiras (COSTA, 1984). 
Quando não relacionadas à um destes ambientes específicos, as corridas de detritos apresentam características semelhantes, quanto à mobilização de materiais e formas de ocorrências.

Dentre os tipos de movimentos de massa, as corridas de detritos se destacam devido à elevada velocidade de fluxo, força de impacto e alcance, causando intensa modificação na paisagem e danos severos. Combinado a estes fatores, soma-se à sua baixa previsibilidade, tornando a sua ocorrência potencialmente perigosa para áreas ocupadas (JAKOB; HUNGR, 2005). Ocorrem em diferentes ambientes climáticos, sendo necessária a presença de excesso de água, oriunda de evento pluviométrico extremo (mais comum em ambientes tropicais) ou até mesmo degelo (em ambiente temperado); fonte abundante de material para transporte, provindos de processos correlatos, tais como escorregamentos e queda de blocos, ou presentes no próprio canal de drenagem; e altas declividades $\left(>25^{\circ}\right)$, que induzem o movimento de transporte e arrastamento de detritos por longas distâncias (COSTA, 1984; SAVAGE; BAUM, 2005; SELBY, 1993; TAKAHASHI, 2007; VANDINE, 1996).

Segundo Takahashi (2007), há três formas principais de deflagração de corridas de detritos (Figura 2.1), 1) a partir de um escorregamento nas encostas, que devido ao excesso de água passa por um processo de liquefação, tornando-se um fluxo visco-plástico com percurso estabelecido em forma de canal (iniciação 1); 2) a partir da remobilização de materiais e rompimento de barragens naturais na própria drenagem (iniciação 2); e 3) a partir do aporte de sedimentos e materiais em drenagens saturadas provindos da ocorrência de escorregamentos nas encostas (iniciação 3). Em ambiente temperado, são comuns a iniciação do tipo 1; já em ambientes tropicais, as iniciações do tipo 2 e 3 são mais frequentes, com destaque para a última. No caso das ocorrências no Brasil, todos os casos estão relacionados à ocorrência de escorregamentos, e consequente fornecimento de materiais pelos mesmos, podendo ocorrer também a remobilização de materiais nas drenagens, após o início do processo (iniciação 2).

A sequência de deflagração de corridas de detritos no Brasil ocorre da seguinte forma (Figura 2.2): o material provindo de escorregamentos nas encostas atingem as drenagens, saturando e tornando-se uma massa de alta viscosidade e poder erosivo (1); o fluxo flui em direção a jusante, remobilizando materiais pré-existentes e erodindo as margens do canal, em um movimento denominado "arrastamento" (2); ao atingir porções mais suaves do relevo, ocorre a deposição parcial dos matérias mais grosseiros, localizados na chamada "frente da corrida" ou "nariz/lóbulo"; e por fim, os materiais atingem as porções mais baixas do relevo, em ângulo inferior a $10^{\circ}$, ocorrendo a deposição final, na qual predominam sedimentos finos e matéria orgânica (AUGUSTO FILHO, 1993; COSTA, 1984; GRAMANI, 2015; TAKAHASHI, 2007; VANDINE, 1996). 
Figura 2.1: Tipos de iniciação de corridas de detritos, segundo Takahashi (2007).

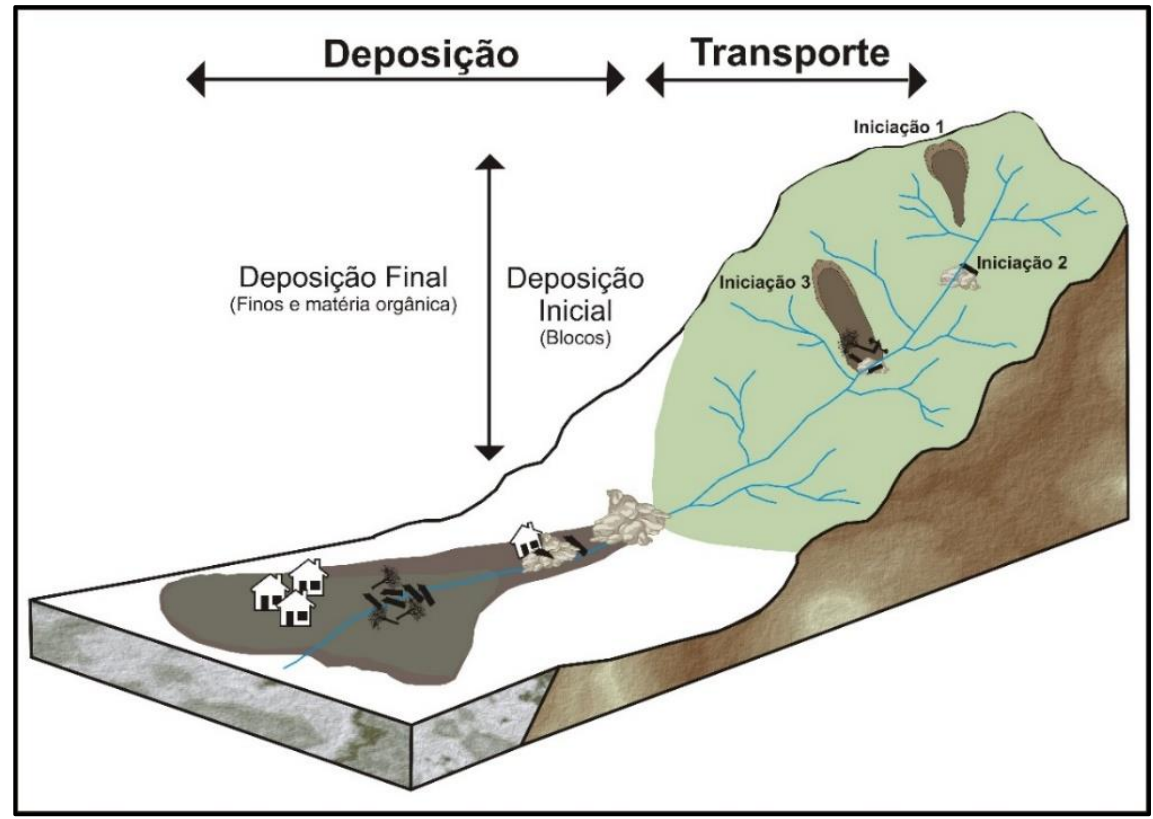

Fonte: Elaborado por Dias, V. C. com base em Jakob (2005b).

Figura 2.2: Esquema ilustrativo da deflagração de corridas de detritos conforme principais mecanismos observados no Brasil.

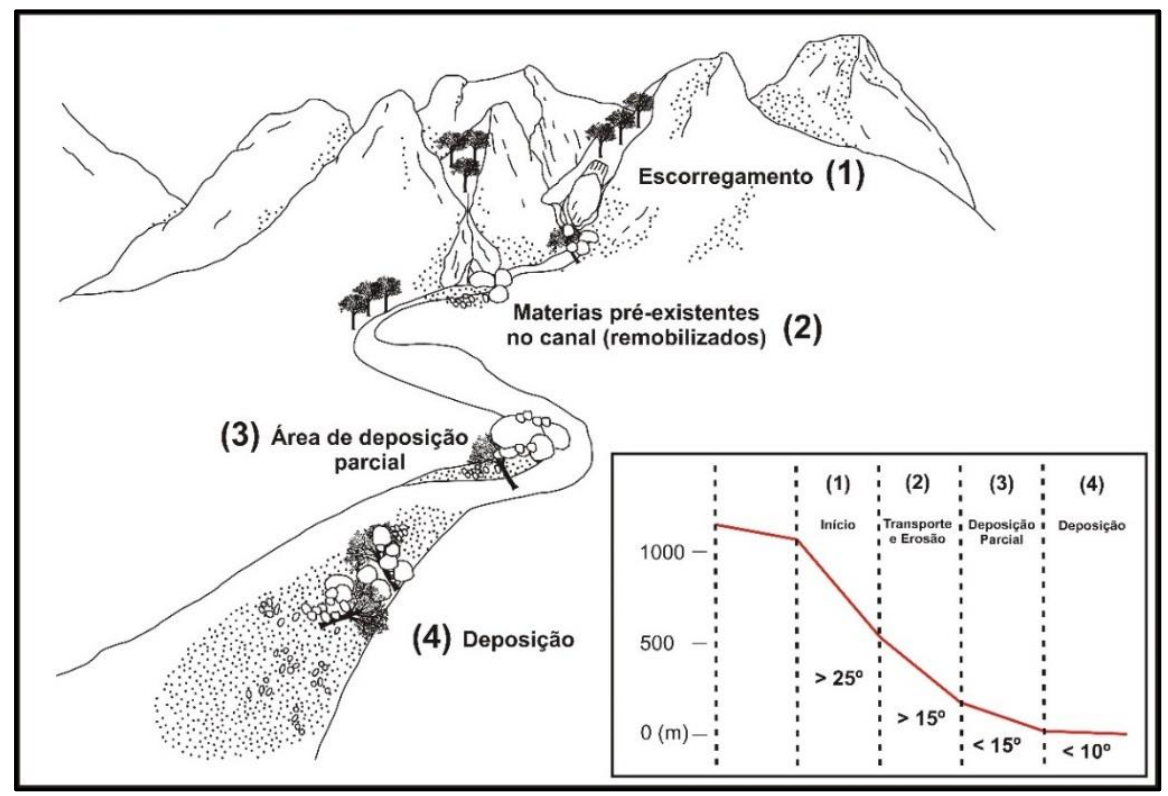

Fonte: Dias (2017) (adaptado de VanDine (1996) e Garcia (2008).

Dada a natureza súbita e devastadora do processo, as corridas de detritos já foram denominadas "Desastre Fantasma", uma vez que os pesquisadores à época não compreendiam como um processo seria capaz de mobilizar blocos gigantescos até as porções mais baixas do relevo (TAKAHASHI, 2007). A partir dos anos 1960, os cientistas começaram a investigar os 
mecanismos das corridas de detritos, buscando compreender como se dava o transporte e a mobilização de materiais (TAKAHASHI, 2007). Costa (1984) e Johnson (1970) identificam cinco mecanismos presentes nas corridas de detritos, que explicam e definem o processo: coesão, flutuabilidade, pressão dispersiva, turbulência e suporte estrutural. De formas e intensidades diferentes, todos os mecanismos influenciam no processo, explicando suas características mais marcantes, como o transporte de blocos gigantescos por longas distâncias, e a forma peculiar de deposição dos mesmos, sempre suspensos por sedimentos mais finos (Tabela 2.1).

Tabela 2.1: Descrição e características dos principais mecanismos atuantes em uma corrida de detritos.

\begin{tabular}{lll}
\hline MECANISMOS DE TRANSPORTE, SUSPENSÃO DE SÓLIDOS E DEPOSIÇÃO EM CORRIDAS DE \\
DETRITOS
\end{tabular}

Fonte: Dias (2017) (adaptado de Costa (1984) e Johnson (1970).

Os materiais que compõe o fluxo podem ter origem e características variadas, sendo desde sedimentos finos, como argila e silte, a materiais mais grosseiros, como blocos e matéria orgânica, sendo a diversidade de frações uma parte fundamental do processo (IVERSON, 1997). Ao analisar a forma como os materiais são transportados, Johnson (1970) observou que o fluxo nas corridas de detritos é basicamente laminar, e que apesar do mecanismo de turbulência estar presente, este não exerce papel fundamental no movimento. $\mathrm{O}$ autor aponta que as corridas lidam suavemente com os materiais transportados, uma vez que os grandes blocos e clastos mais frágeis mantém suas respectivas características durante o transporte, não indicando, portanto, a predominância de um movimento turbulento, comum as enxurradas, por 
exemplo. Dessa forma, a natureza visco-plástica do fluxo faz com que os diferentes materiais boiem, em suspenção (Figura 2.3) (JOHNSON, 1970).

Figura 2.3: Diagrama esquemático ilustrando a distinção entre uma fração fina, que se mantém suspensa exclusivamente pelas forças de viscosidade e que, portanto, atua como parte do fluído (grão A) e uma fração grosseira que requer interação com outros grãos para se manter suspensa (grão B).

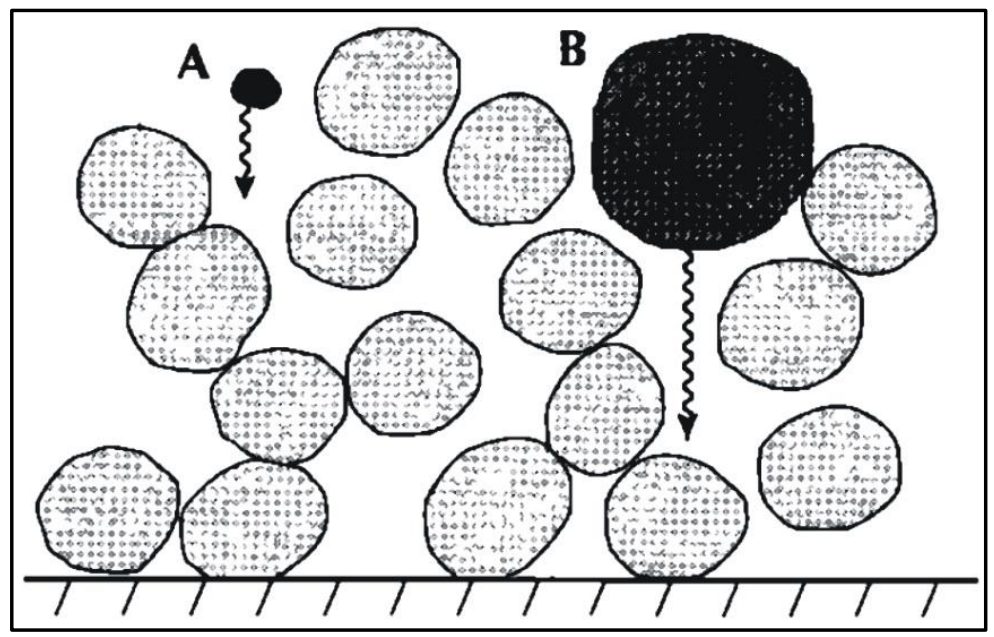

Fonte: modificado de Iverson (1997).

A partir da atuação de cada mecanismo, é possível compreender o processo como um todo, desde o seu transporte até as características morfológicas de sua deposição. A parte principal da corrida é denominada "frente", ou "nariz", e é composta por materiais mais grosseiros, como grandes blocos, que se movimentam em suspenção devido aos mecanismos de "flutuabilidade" (que dá suporte aos materiais), e "pressão dispersiva" (que faz com que materiais mais grosseiros boiem para a superfície). Já na parte final da corrida, denominada "cauda", predominam os materiais finos, sendo estes movidos pelos mecanismos de "coesão" e "turbulência", responsáveis pelo transporte e suporte dos sedimentos (EISBACHER; CLAGUE, 1984; JOHNSON, 1970; UJUETA; MOJICA, 1995) (Figura 2.4). 
Figura 2.4: Perfil esquemático de uma corrida de detritos.

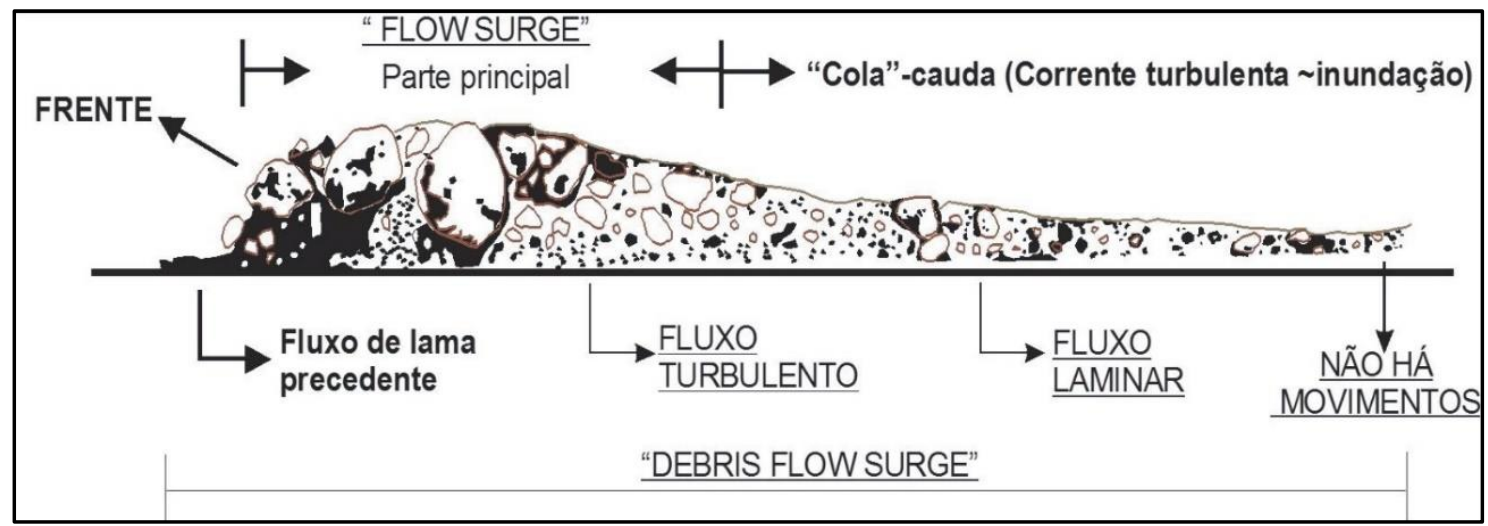

Fonte: modificado de Ujueta; Mojica (1995).

Em sua deposição, as corridas de detritos apresentam elementos bem específicos, mais uma vez, derivados dos mecanismos anteriormente citados, que são vitais para a sua correta identificação em campo. A falta de seleção dos materiais e a inversão granulométrica são duas das principais características a serem verificadas nos depósitos (Figura 2.5). Ambas derivam dos mecanismos de "pressão dispersiva", responsável pela mobilização dos blocos maiores em direção à superfície entre os sedimentos mais finos, não havendo, portanto, uma seleção dos materiais em ação; e o "suporte estrutural", que age apenas na deposição dos materiais, responsável por manter grandes blocos suspensos pelos materiais mais finos, ou seja, a chamada inversão granulométrica. Outra característica apontada por Jakob (2005a) é a presença de blocos muito grandes, uma vez que estes só poderiam ser mobilizados por um fluxo do tipo "não-newtoniano"; a presença de marcas nas árvores logo acima do limite dos canais (principalmente no hemisfério norte) (Figura 2.6); e rastros bem definidos percorridos pela corrida com a formação de "ondas laterais" (Figura 2.7). 
Figura 2.5: Inversão granulométrica em depósitos de corridas de detritos na Serra da Prata, Paraná (a) e em Caraguatatuba, São Paulo (b).

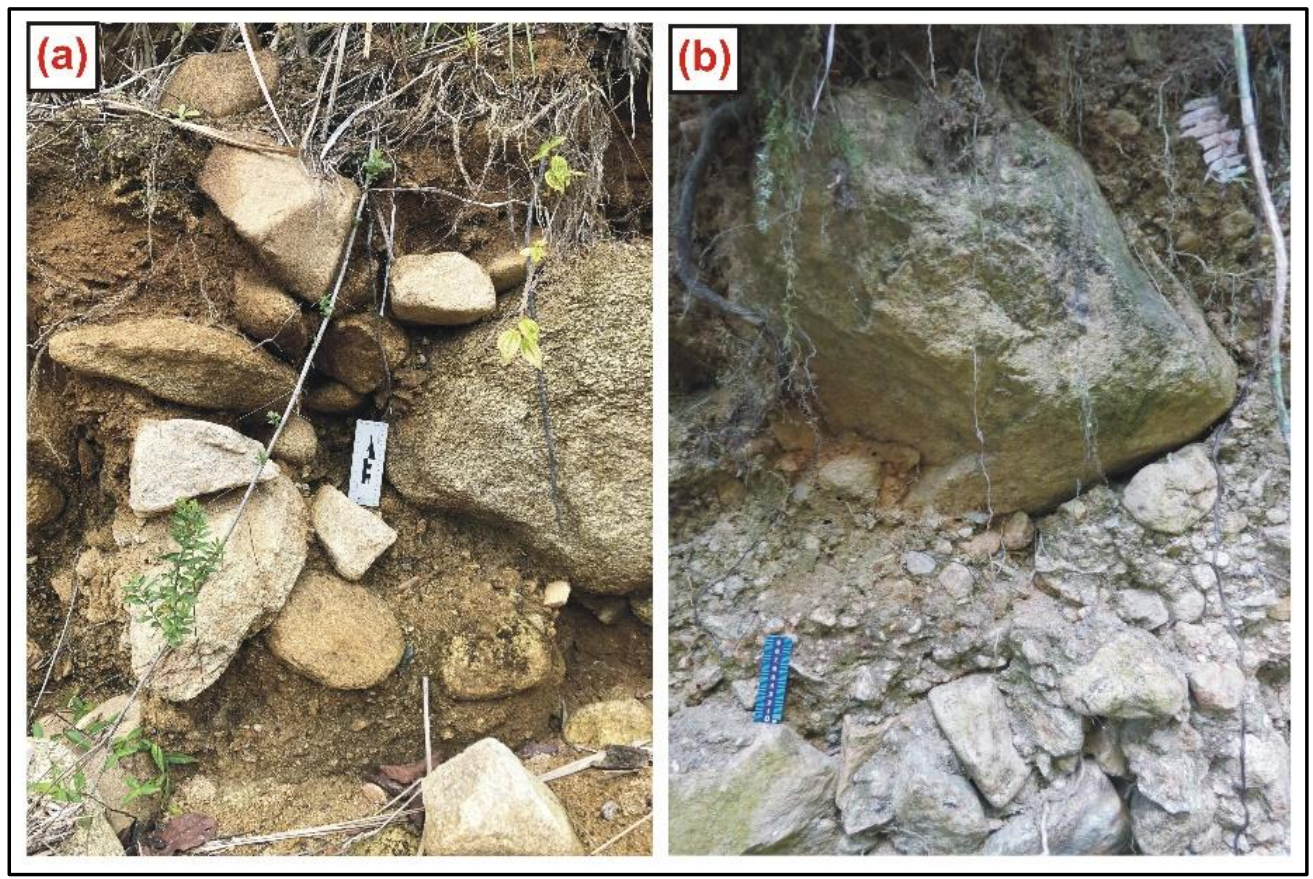

Fonte: Gramani, M. F. (b).

Figura 2.6: Depósito de corridas de detritos com marcação nas árvores, em Lillooet, no Canadá.

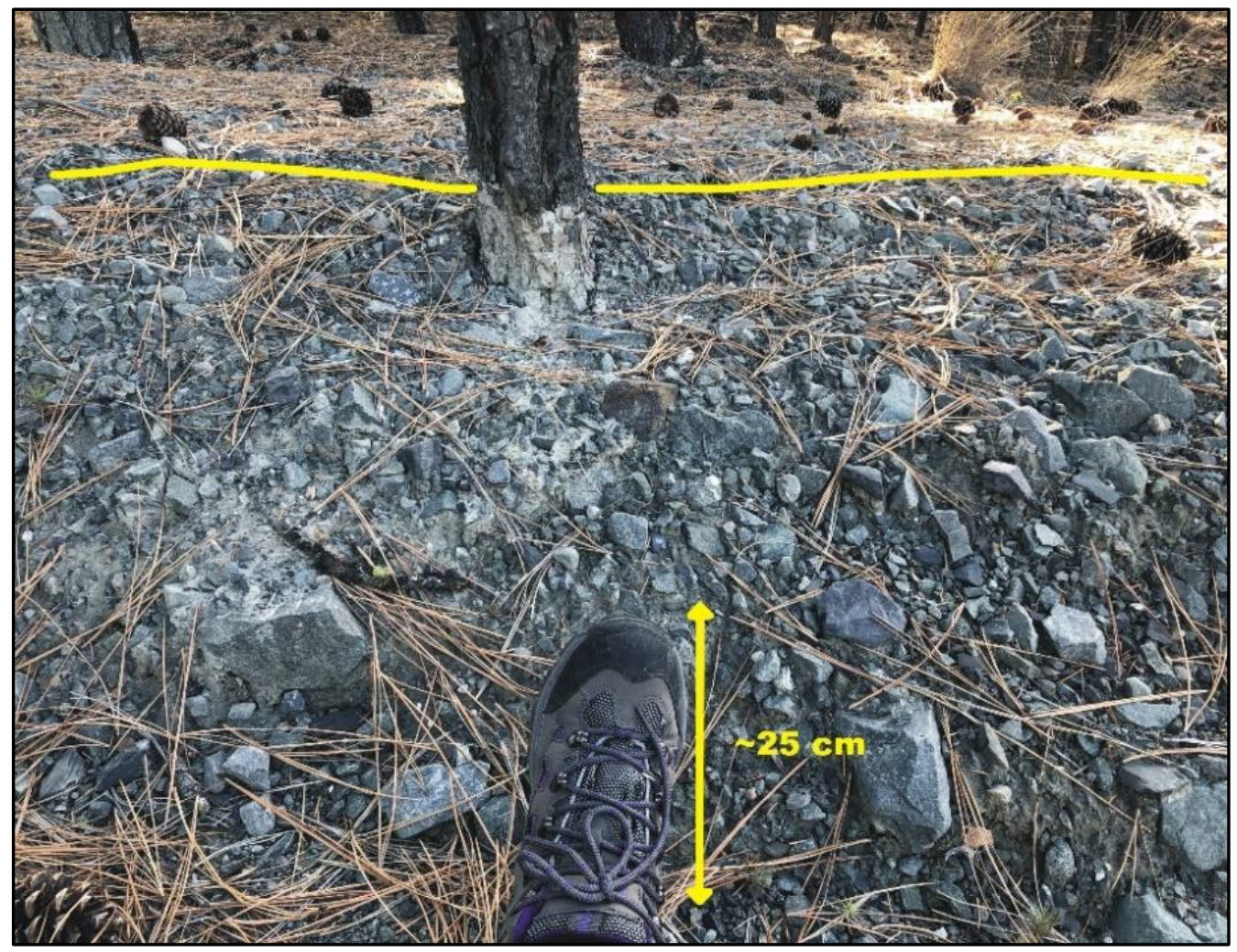


Figura 2.7: Representação das feições deposicionais de uma corrida de detritos (a e b) e depósitos de corridas de detritos observados em campo, no Paraná (c) e em São Paulo (d).

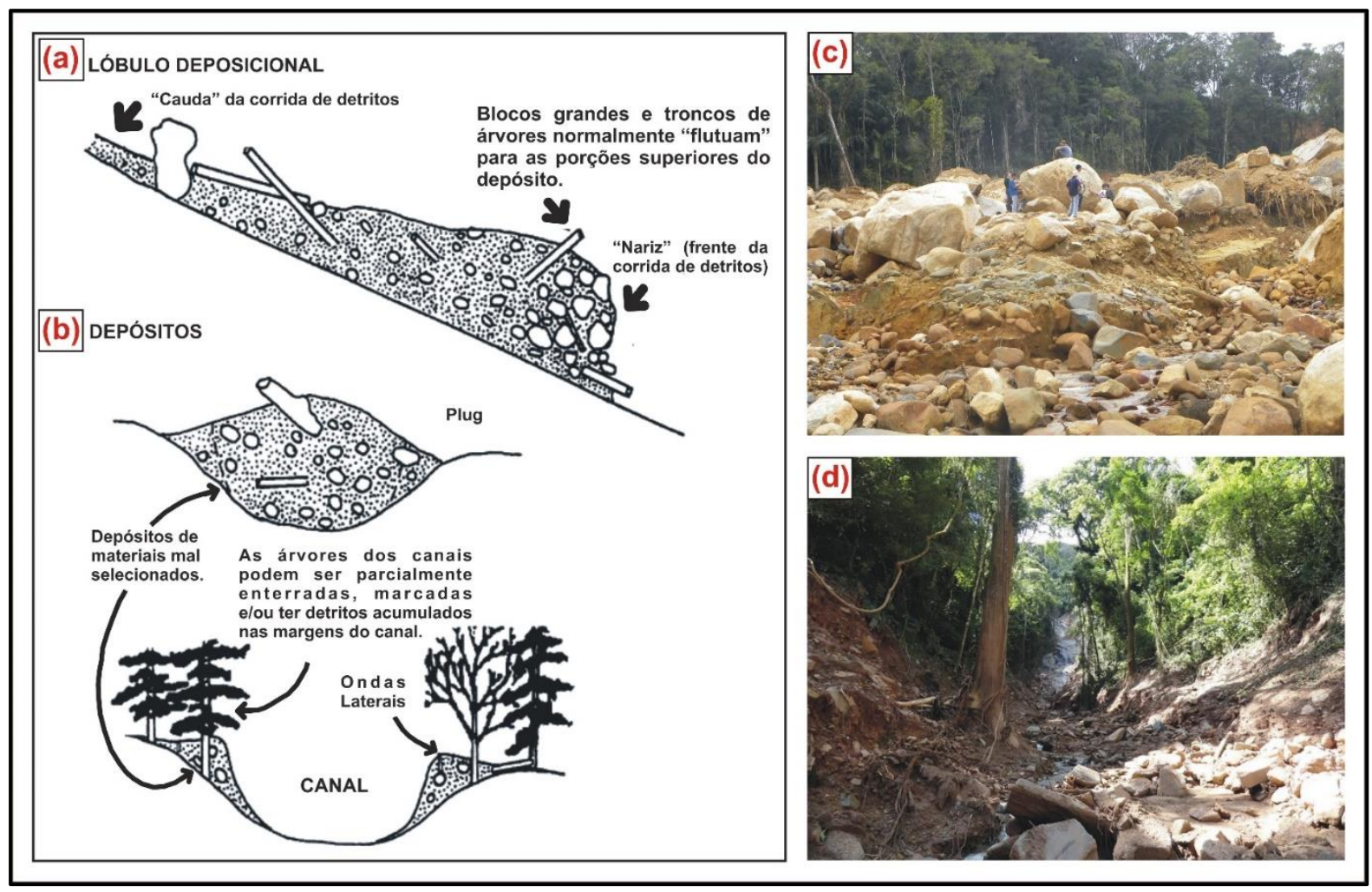

Fonte: modificado de Eisbacher; Clague (1984) (Ilustração); GPmorfo (Foto c) e Instituto Geológico do Estado de São Paulo (Foto d).

\subsection{Principais ocorrências no Brasil}

No Brasil é frequente a ocorrência de corridas de detritos de elevada magnitude e potencial destrutivo, tendo elas causado inúmeras perdas econômicas, sociais e humanas ao longo dos anos. Dada a configuração geológica-geomorfológica e climática da Serra do Mar, as regiões Sul e Sudeste do país apresentam o maior número de ocorrências, com destaque para o litoral dos Estados do Rio de Janeiro, São Paulo e Paraná (Figura 2.8). Segundo relatório do Banco Mundial, apenas nas ocorrência de 2008 e 2011 os custos relacionados à desastres naturais no Brasil foram superiores à \$ 3 bilhões de dólares (WORLD BANK, 2014). Com relação ao desastre de 2011 na região Serrana do Rio de Janeiro, os gastos decorrentes do evento representaram cerca de $36 \%$ do valor total do PIB da região (WORLD BANK, 2014). Somado à economia, as perdas de vidas humanas ultrapassaram os 1.000 mortos, com elevado número de desaparecidos. Segundo avaliações, a maior parte dos danos foi causado por corridas de detritos, dado ao seu elevado potencial de transporte e alcance (AVELAR et al., 2013; COELHO-NETTO et al., 2013). 
Figura 2.8: Localização da Serra do Mar e principais ocorrências (a) e perdas (b) relacionadas à ocorrência de movimentos de massa.

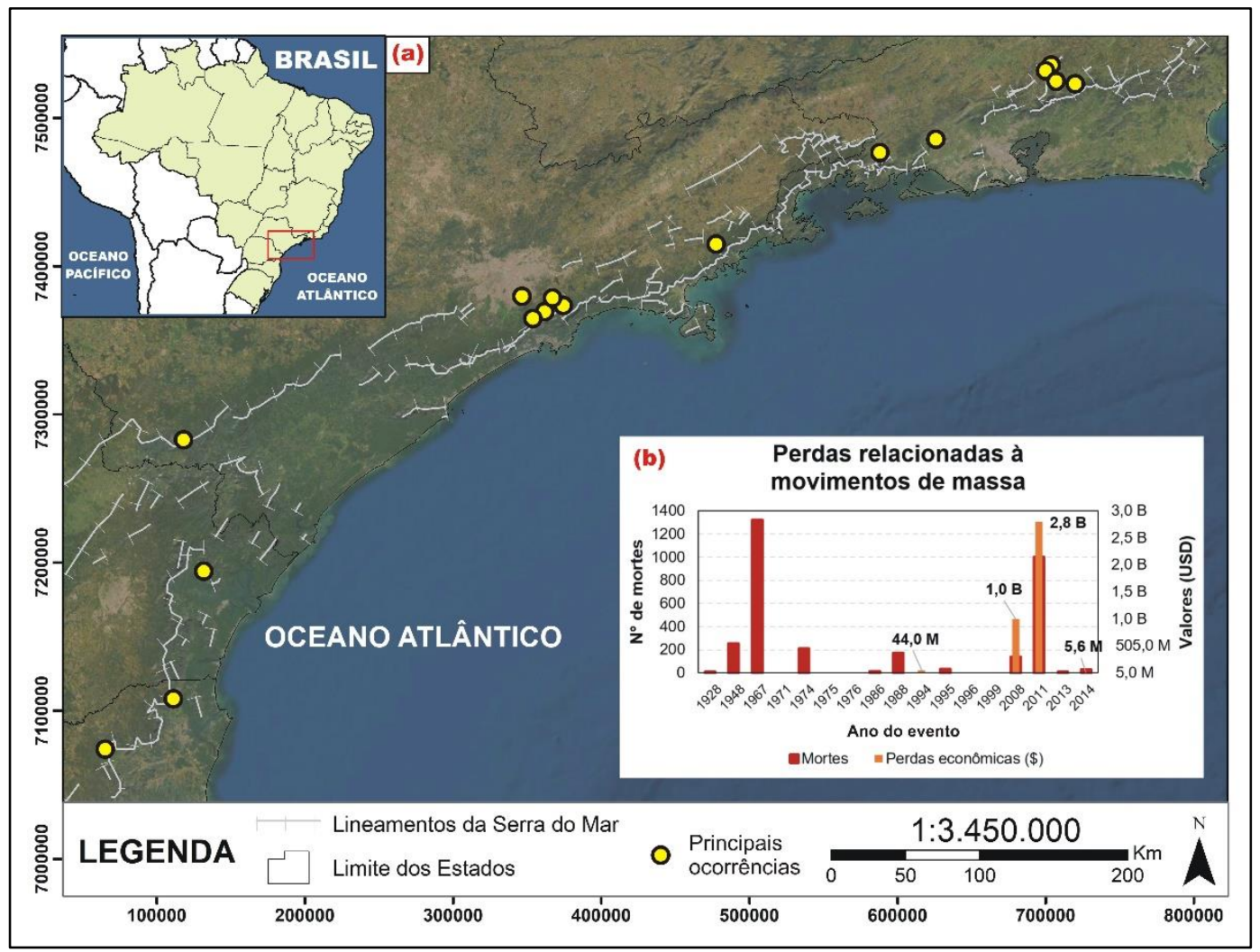

Fonte: Esri, DigitalGlobe, GeoEye, Earthstar Geographics, CNES/Airbus DS, USDA, USGS, AeroGRID, IGN, and the GIS User Community (imagem); KANJI et al. (2017); WORLD BANK (2014) (dados).

A Tabela 2.2 apresenta um compilado das ocorrências de corridas de detritos registradas, que datam desde 1928. No entanto, nem todas as informações a respeito da ocorrência foram observadas e catalogadas. Dados como precipitação, velocidade, volume transportado e área são de vital importância para a elaboração de um banco de dados para posteriores trabalhos de remediação e previsão de novos eventos, e se não forem coletados logo após a ocorrência, perdem-se ao longo da história, uma vez que a própria paisagem se encarrega de ocultar as marcas dos processos de outrora (HUEBL; FIEBIGER, 2005; JAKOB, 2005a).

Dentre as inúmeras ocorrências, algumas se destacam devido tanto aos danos causados e magnitude do processo, quanto por terem sido o motivador de mudanças quanto a forma que o país lida com a previsão e mitigação de desastres. O ano de 1967 se destaca pela ocorrência de dois importantes eventos, na Serra das Araras, no Estado do Rio de Janeiro, e na cidade de Caraguatatuba, no Estado de São Paulo. O evento nas Serra das Araras ocorreu após evento pluviométrico extremo $(275 \mathrm{~mm} / 24 \mathrm{~h})$ que culminou com a deflagração de escorregamentos e corridas de detritos que causaram danos às infraestruturas, como a rodovia Rio-São Paulo, a 
destruição de dezenas de casas e um saldo de 1.200 mortos. Estima-se que um volume maior que 10.000.000 $\mathrm{m}^{3}$ de materiais foram mobilizados pelas corridas de detritos (KANJI et al., 2017; VIEIRA; GRAMANI, 2015) (Figura 2.9).

Figura 2.9: Ocorrência na Serra das Araras, em 1967. Escorregamentos deflagrados nas encostas (a); Destruição de rodovia Rio-São Paulo (b).

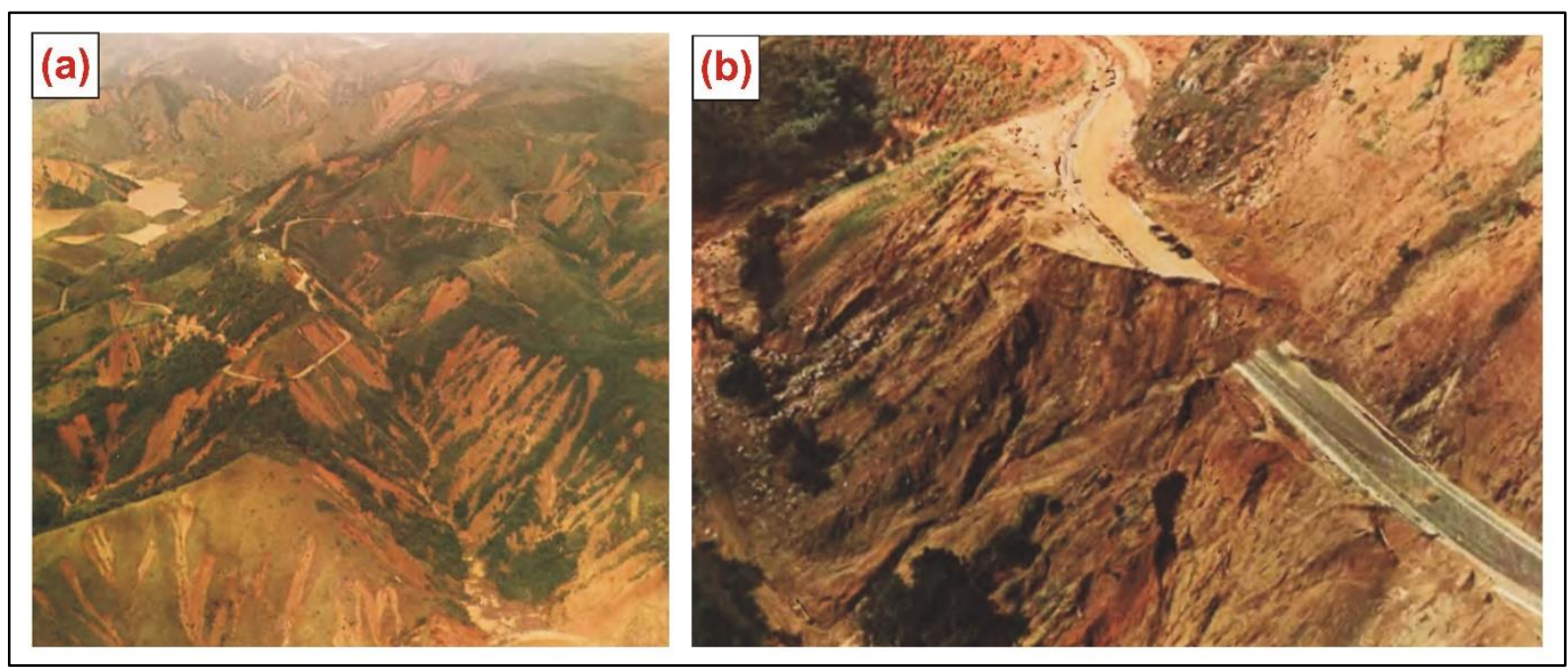

Fonte: Jones (1973).

Tabela 2.2: Principais casos brasileiros, das regiões sul e sudeste, de ocorrência de corridas de detritos.

\begin{tabular}{|c|c|c|c|c|}
\hline OCORRÊNCIA & PRECIPITAÇÃO & VELOCIDADE & VOLUME $\left(\mathbf{M}^{3}\right)$ & PERDAS \\
\hline $\begin{array}{l}\text { Mont Serrat (SP) } \\
-1928\end{array}$ & - & - & Vol: > $1 \times 10^{5}$ & $\begin{array}{l}6 \text { mortos, destruição da } \\
\text { Santa Casa. }\end{array}$ \\
\hline $\begin{array}{l}\text { Vale do Paraíba } \\
\text { (MG/SP) - } \\
\text { 15/12/1948 }\end{array}$ & $180 \mathrm{~mm} / 24$ horas & - & - & 250 mortes \\
\hline $\begin{array}{l}\text { Serra das Araras } \\
(\mathrm{RJ})-\mathbf{2 3 / 0 1 / 1 9 6 7}\end{array}$ & $275 \mathrm{~mm} / 12$ horas & - & $>10 \times 10^{6} \mathrm{~m}^{3}$ & $\begin{array}{l}1200 \text { mortos, > } 100 \\
\text { casas destruídas, danos } \\
\text { a rodovias. }\end{array}$ \\
\hline $\begin{array}{l}\text { Caraguatatuba } \\
\text { (SP) - 18/03/1967 }\end{array}$ & $586 \mathrm{~mm} / 24$ horas & - & $7,6 \times 10^{6} \mathrm{~m}^{3}$ & $\begin{array}{l}120 \text { mortos, } 400 \text { casas } \\
\text { destruídas, em } \\
\text { rodovias. }\end{array}$ \\
\hline $\begin{array}{l}\text { Cubatão (SP) - } \\
\text { 24-27/02/1971 }\end{array}$ & - & - & - & Destruição de ponte. \\
\hline $\begin{array}{l}\text { Viaduto IV da } \\
\text { ferrovia Santos- } \\
\text { Jundiaí (SP) - } \\
1971\end{array}$ & - & - & $\begin{array}{l}1 \times 10^{5} \mathrm{~m}^{3} \\
\text { (estimado) }\end{array}$ & $\begin{array}{l}\text { Viaduto de aço } \\
\text { destruído, o que exigiu } \\
\text { obras de estabilização } \\
\text { de encostas. }\end{array}$ \\
\hline $\begin{array}{l}\text { Tubarão (SC) - } \\
\text { Março de } 1974\end{array}$ & $742 \mathrm{~mm} / 16$ dias & - & - & 199 mortes. \\
\hline $\begin{array}{l}\text { Grota Funda } \\
\text { (SP) - 1975/1976 }\end{array}$ & $381 \mathrm{~mm} / 1$ mês & $30 \mathrm{~km} / \mathrm{h}$ & $1.000 .000 \mathrm{~m}^{3}$ & $\begin{array}{l}\text { Pilares de ponte } \\
\text { ferroviária danificados. }\end{array}$ \\
\hline $\begin{array}{l}\text { COPEBRÁS } \\
\text { (SP) - 27- } \\
\text { 30/02/1976 }\end{array}$ & - & - & $100.000 \mathrm{~m}^{3}$ & $\begin{array}{l}\text { Inundação da } \\
\text { COPEBRÁS. }\end{array}$ \\
\hline $\begin{array}{l}\text { RPBC (SP) - 22- } \\
25 / 02 / 1985\end{array}$ & - & - & - & Inundação da RPBC. \\
\hline
\end{tabular}




\begin{tabular}{|c|c|c|c|c|}
\hline $\begin{array}{l}\text { Lavrinha (SP) - } \\
\text { Dezembro de } \\
1986\end{array}$ & - & $80 \mathrm{~km} / \mathrm{h}$ & $160.000 \mathrm{~m}^{3}$ & 11 mortos \\
\hline $\begin{array}{l}\text { Petrópolis }(\mathbf{R J}) \text { - } \\
\text { Fevereiro de } \\
1988\end{array}$ & $776 \mathrm{~mm} / 24 \mathrm{dias}$ & - & - & 171 mortos \\
\hline $\begin{array}{l}\text { Cubatão (SP) - } \\
\text { 20-22/02/1988 }\end{array}$ & - & - & - & $\begin{array}{l}10 \text { mortes, } 3 \text { pontes e } \\
\text { algumas casas } \\
\text { destruídas. }\end{array}$ \\
\hline $\begin{array}{l}\text { Bacia do Rio das } \\
\text { Pedras (SP) - } \\
\text { 06/02/1994 }\end{array}$ & $280 \mathrm{~mm} / 24$ horas & $10 \mathrm{~m} / \mathrm{s}$ & $300.000 \mathrm{~m}^{3}$ & $\begin{array}{l}\text { Destruição de } 8 \\
\text { barragens de gabião e } \\
\text { prejuízos à Refinaria } \\
\text { Presidente Bernardes. }\end{array}$ \\
\hline $\begin{array}{l}\text { Timbé do Sul } \\
\text { (SC/RS) - } \\
\text { Dezembro de } \\
1995\end{array}$ & $>500 \mathrm{~mm} / 1$ hora & $>5 \mathrm{~m} / \mathrm{s}$ & $\begin{array}{c}3 \times 10^{6} 15 \text { metros de } \\
\text { altura }\end{array}$ & $\begin{array}{l}29 \text { mortos, } 20 \text { casas } \\
\text { destruídas, perdas } \\
\text { (agricultura e gado). }\end{array}$ \\
\hline $\begin{array}{l}\text { Bacia do Rio das } \\
\text { Pedras (SP) - } \\
1996\end{array}$ & - & - & $16.000 \mathrm{~m}^{3}$ & $\begin{array}{l}\text { Apenas trabalho de } \\
\text { limpeza. }\end{array}$ \\
\hline $\begin{array}{l}\text { Rodovia de } \\
\text { Ubatuba (SP) - } \\
1996\end{array}$ & $442 \mathrm{~mm} / 13$ horas. & - & - & $\begin{array}{l}\text { Rodovia foi danificada, } \\
\text { o que exigiu obras de } \\
\text { estabilização da } \\
\text { encosta. }\end{array}$ \\
\hline $\begin{array}{l}\text { Maciço do } \\
\text { Quitite e } \\
\text { Papagaio (RJ) - } \\
\text { Fevereiro de } \\
1996\end{array}$ & $300 \mathrm{~mm} / 48$ horas & $5,3 \mathrm{~m} / \mathrm{s}$ & $\begin{array}{c}100.000 \mathrm{~m}^{3} \text { (Bacia } \\
\text { do Quitite) e } 42.000 \\
\mathrm{~m}^{3} \text { (Bacia do } \\
\text { Papagaio) }\end{array}$ & $\begin{array}{l}1 \text { morte e centenas de } \\
\text { casas destruídas. }\end{array}$ \\
\hline $\begin{array}{l}\text { Rodovia } \\
\text { Anchieta (SP) - } \\
\text { 12/12/1999 }\end{array}$ & $274 \mathrm{~mm} / 72$ horas & - & $300.000 \mathrm{~m}^{3}$ & $\begin{array}{l}200 \mathrm{~m} \text { da área afetada e } \\
\text { tráfego interrompido } \\
\text { por várias semanas }\end{array}$ \\
\hline $\begin{array}{l}\text { Campos do } \\
\text { Jordão (SP) - } \\
\text { Janeiro de } 2000\end{array}$ & $453,2 \mathrm{~mm} / 96$ horas & - & - & $\begin{array}{l}10 \text { mortes e } 300 \\
\text { residências } \\
\text { desocupadas por } \\
\text { situação de risco. }\end{array}$ \\
\hline $\begin{array}{l}\text { Fazenda mato } \\
\text { Quieto (SP) - } \\
\text { Janeiro de } 2000\end{array}$ & $>70 \mathrm{~mm} / 1$ hora & $22 \mathrm{~m} / \mathrm{s}$ & $1,6 \times 10^{6} \mathrm{~m}^{3}$ & $\begin{array}{l}11 \text { mortes, casas e } \\
\text { pontes destruídas. }\end{array}$ \\
\hline $\begin{array}{l}\text { Vale do Itajaí } \\
\text { (SC) Novembro } \\
\text { de } 2008\end{array}$ & $185,8 \mathrm{~mm} / 48$ horas & - & - & $\begin{array}{l}78.000 \text { pessoas } \\
\text { desalojadas, } 135 \\
\text { mortes e } 2 \\
\text { desaparecidos. }\end{array}$ \\
\hline $\begin{array}{l}\text { Região Serrana } \\
\text { do Rio de } \\
\text { Janeiro (RJ) - } \\
\text { Córrego D'antas } \\
\text { e Córrego das } \\
\text { Vieiras - Janeiro } \\
\text { de } 2011\end{array}$ & $266 \mathrm{~mm} / 48$ horas & $8,5 \mathrm{~m} / \mathrm{s}$ & - & $\begin{array}{l}429 \text { mortes, pessoas } \\
\text { desaparecidas, } 3.220 \\
\text { desalojados, } 2.031 \\
\text { desabrigados e } \\
\text { inúmeros } \\
\text { prejuízos }\end{array}$ \\
\hline $\begin{array}{l}\text { Região Serrana } \\
\text { do Rio de } \\
\text { Janeiro (RJ) - } \\
\text { Bairro da Posse - } \\
\text { Janeiro de } 2011\end{array}$ & $270 \mathrm{~mm} / 24$ horas & - & - & $\begin{array}{l}343 \text { mortes, pessoas } \\
\text { desaparecidas, } 9.110 \\
\text { desalojados, } 6.727 \\
\text { desabrigados e } \\
\text { inúmeros } \\
\text { prejuízos }\end{array}$ \\
\hline $\begin{array}{l}\text { Região Serrana } \\
\text { do Rio de } \\
\text { Janeiro (RJ) - } \\
\text { Córrego do }\end{array}$ & - & - & $100.000 \mathrm{~m}^{3}$ & $\begin{array}{l}71 \text { mortes, pessoas } \\
\text { desaparecidas, } 6.223 \\
\text { desalojados, } 191 \\
\text { desabrigados e }\end{array}$ \\
\hline
\end{tabular}




\begin{tabular}{|c|c|c|c|c|}
\hline $\begin{array}{l}\text { Cuiabá - Janeiro } \\
\text { de } 2011\end{array}$ & & & & $\begin{array}{l}\text { inúmeros } \\
\text { prejuízos }\end{array}$ \\
\hline $\begin{array}{l}\text { Serra da Prata } \\
(P R)-11 / 03 / 2011\end{array}$ & $575 \mathrm{~mm} / 72$ horas & - & - & $\begin{array}{l}\text { Prejuízos por } \\
\text { destruição total } \\
\text { ou parcial de casas, } \\
\text { ruas, } \\
\text { estradas, pontes e } \\
\text { lavouras. } \\
21 \text { pessoas feridas e } 1 \\
\text { óbito }\end{array}$ \\
\hline $\begin{array}{l}\text { Ribeirão do } \\
\text { Cágado (SP) - } \\
2013\end{array}$ & $273,6 \mathrm{~mm} / 24$ horas & - & - & $\begin{array}{l}\text { Danos na adutora da } \\
\text { Sabesp. }\end{array}$ \\
\hline $\begin{array}{l}\text { Córrego } \\
\text { Guarda-mão } \\
\text { (SP) - Janeiro de } \\
2014\end{array}$ & $210 \mathrm{~mm} / 2$ horas & - & - & $\begin{array}{l}\text { Destruição de } \\
\text { plantações, } \\
\text { moradias, pontes, } \\
\text { estradas, } \\
25 \text { mortos e } 2 \\
\text { desaparecidos }\end{array}$ \\
\hline
\end{tabular}

Fonte: modificado de Corrêa (2018). Copilado de Dados de: Corrêa, 2018; Corrêa et al., 2015; Gramani, 2001a; JICA, 1991; Kanji et al., 2017; Kanji; Massad; Cruz, 2003; Kobiyama; Michel, 2014; Nery, 2016; Polanco, 2001; Sakai, 2014; Silveira, 2019; Sternberg, 1949; Vieira; Gramani, 2015.

Apesar de ter causado danos menores quando comparada ao evento na Serra das Araras, a ocorrência em Caraguatatuba se destaca devido à grande quantidade de materiais mobilizados pelos processos, cerca de 2 milhões de toneladas de sedimentos (PETRI; SUGUIO, 1971). Após elevado acumulado de chuva nos meses anteriores, nos dias 17 e 18 de março o volume crítico de $586 \mathrm{~mm}$ em apenas 48 horas deflagrou escorregamentos nas encostas e corridas de detritos nas drenagens, destruindo casas, rodovias e deixando 120 mortos (CRUZ, 1974; DE PLOEY; CRUZ, 1979) (Figura 2.10). Acredita-se que a tragédia em Caraguatatuba não tenha sido maior pois a cidade, à época, ainda era pouco povoada. 
Figura 2.10: Desastre ocorrido em 1967, na cidade de Caraguatatuba/SP. Depósito de corridas de detritos (a); infraestruturas destruídas no centro urbano da cidade (b).

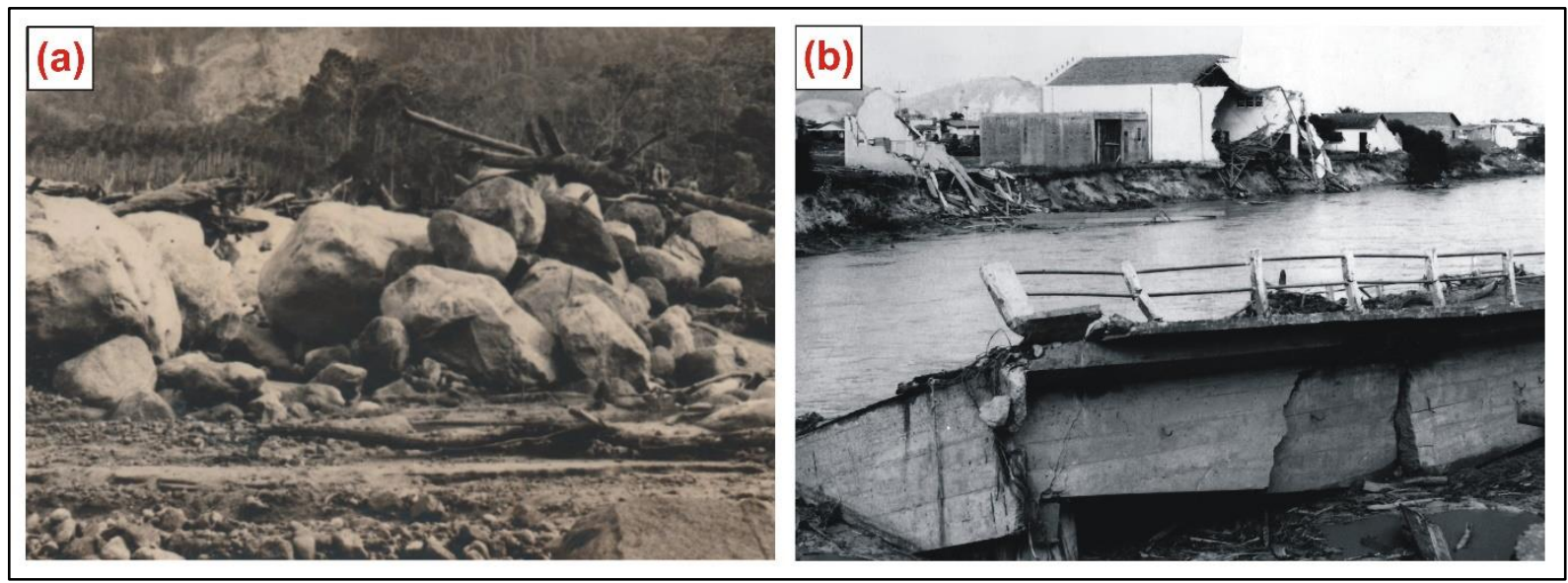

Fonte: Cruz, O. (a) e Arquivo Público de Caraguatatuba (b).

As décadas seguintes foram marcadas por novas ocorrências na região da Serra do Mar, em diferentes localidades, com destaque para o município de Cubatão, na Baixada Santista do Estado de São Paulo, com prejuízos majoritariamente econômicos às indústrias localizadas nos sopés das encostas. No período de menos de 20 anos, Cubatão registou ao menos quatro ocorrências marcantes relacionadas às corridas de detritos. Em janeiro de 1976 corridas de detritos atingiram a COPEBRÁS ${ }^{2}$, gerando um depósito de aprox. $100.000 \mathrm{~m}^{3}$, além de provocar a destruição de duas barragens de terra e alvenaria (JICA, 1991; KANJI et al., 2017). Em 22/23 de janeiro de 1985, evento pluviométrico extremo contribuiu para a deflagração de escorregamentos e corridas de detritos (Figura 2.11a e b), que inundaram a Refinaria Presidente Bernardes (RPBC). Segundo Gramani (2001b), o elevado volume de sedimentos bloqueou diversos cursos d'água, com destaque para o Rio Mogi. Apenas 3 anos depois, em janeiro de 1988, escorregamentos e corridas de detritos foram deflagrados devido ao elevado volume pluviométrico, destruindo 3 pontes, residências e causando a morte de 10 pessoas (JICA, 1991; VIEIRA; GRAMANI, 2015).

Em fevereiro de 1994, uma nova ocorrência causou danos milionários ao atingir as instalações da Refinaria da Petrobrás, que foi inundada com detritos, causando a interrupção das operações (KANJI et al., 1997, 2017; KANJI; CRUZ; MASSAD, 2008). (Figura 2.11c e d). Recentemente, no ano de 2013, em 22 de fevereiro, volumes pluviométricos elevados deflagraram uma nova ocorrência de corridas de detritos, causando danos as instalações da SABESP, além da interdição de viaduto na Rodovia dos Imigrantes (KANJI et al., 2017).

\footnotetext{
${ }^{2}$ Industria de Fosfatados: http://cmocbrasil.com/br/negocios/copebras
} 
Segundo informações da rede pluviométrica instalada na região pelo Departamento de Água e Energia Elétrica (DAEE), o volume de chuvas chegou ao volume total de $272 \mathrm{~mm}$ em 24 horas, no dia da ocorrência (ALTRICHTER; GRAMANI, 2014). As instalações da SABESP, na bacia do Rio Pilões, foram atingidas por elevado volume de materiais, que incluíam blocos, matéria orgânica e lama, que danificaram estruturas e tanques de cloro, além de destruir um escritório e inundar a instalação (Figura 2.11e) (GRAMANI, 2013; KANJI et al., 2017). A ocorrência na Rodovia dos Imigrantes provocou o fechamento da mesma pela primeira vez desde a sua inauguração, em 1976. As corridas de detritos tomaram as pistas da rodovia na entrada do Túnel "TA 10/11", causando o arraste de 24 veículos e a morte de uma pessoa (Figura 2.11f). Vistorias realizadas posteriormente revelaram cerca de 70 locais com deslizamentos no Sistema Anchieta-Imigrantes, sendo o mais grave a ocorrência no Km 52, cujos materiais transportados variaram entre rochas, troncos de árvores e lama (ALTRICHTER; GRAMANI, 2014). 
Figura 2.11: Principais ocorrências de corridas de detritos em Cubatão/SP, em 1985 (a e b); 1994 (c e d); e 2013 (e e f). (a): Destaque para os depósitos de corridas de detritos, no fundo dos vales; (b): Vista lateral, mostrando a grande quantidade de escorregamentos; (c): Região atingida pelos escorregamentos e corridas de detritos. Detalhe para as cicatrizes das corridas de detritos, que antingiram a refinaria no sopé da encosta; (d): Depósito de corridas de detritos localizado no Rio das Pedras; (e): Área atingida por corridas de detritos nas instalações da SABESP; (f): Carros arrastados pela corrida de detritos na Rodovia dos Imigrantes na ocasião do processo.
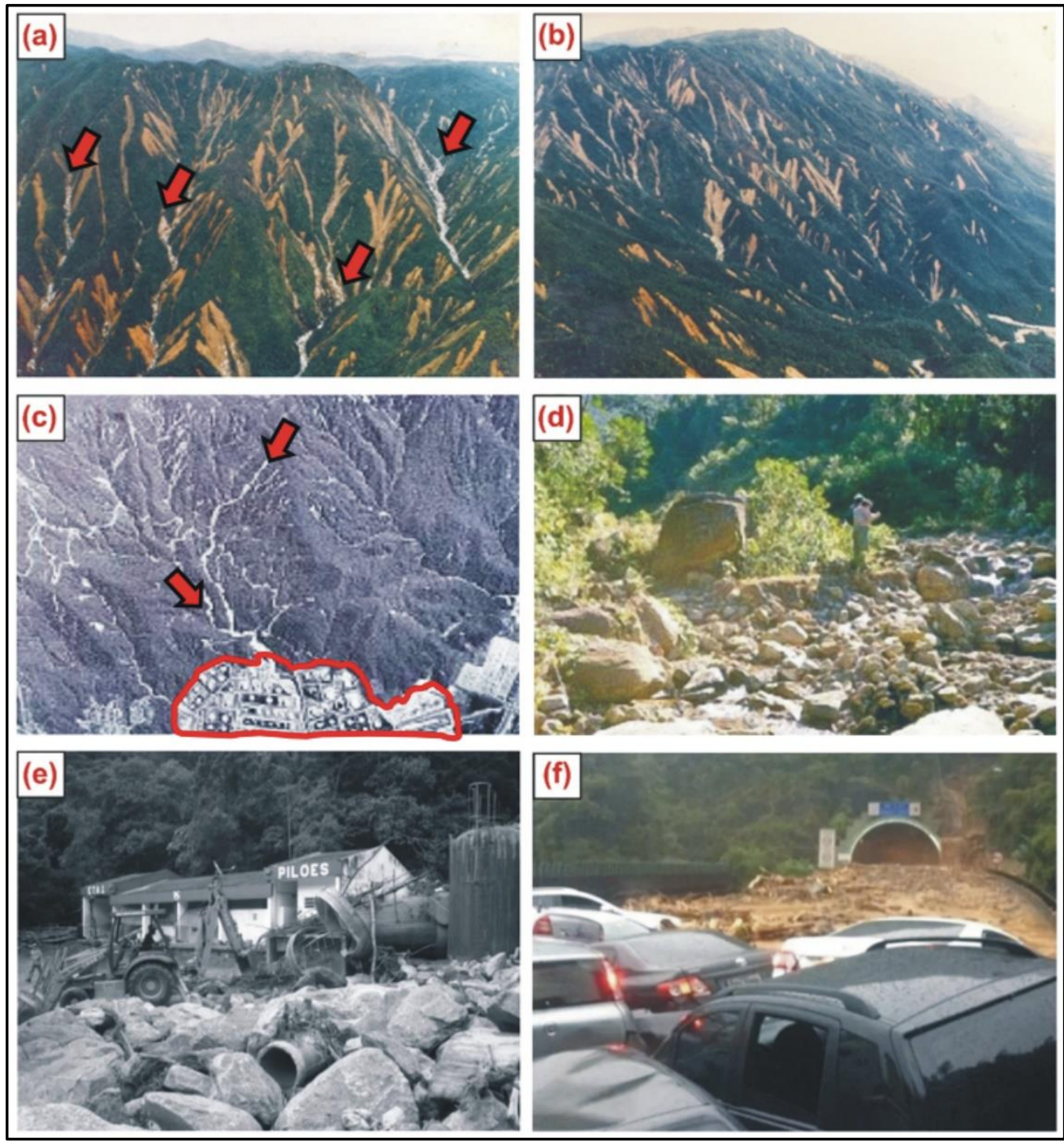

Fontes: IPT (1986) (a e b); Gramani (2001a) (c e d), modificado de Araujo Filho et al. (1998) (c); Gramani (2013) (e); Estadão (2013) (f).

Nos dias 22 e 23 de novembro de 2008, a cidades do Vale do Itajaí, em Santa Catarina, foram atingidas por elevados volumes pluviométricos, com medições que chegaram à $495 \mathrm{~mm}$ em dois dias ${ }^{3}$ (GRAMANI et al., 2009), causando enchentes, inundações e movimentos de massa (FARIA et al., 2008; KANJI et al., 2017; TOMAZZOLI; FLORES; BAUZYS, 2009). Uma das áreas mais atingidas foi o chamado Complexo do Baú, onde ocorreram, além das

\footnotetext{
${ }^{3}$ Dados pluviométricos de Blumenau.
} 
enchentes e inundações, escorregamentos e corridas de detritos, que causaram danos à infraestrutura local, moradias e óbitos (Figura 2.12).

Figura 2.12: Movimentos de massa e enchentes ocorridos em 2008, no Vale do Itajaí.

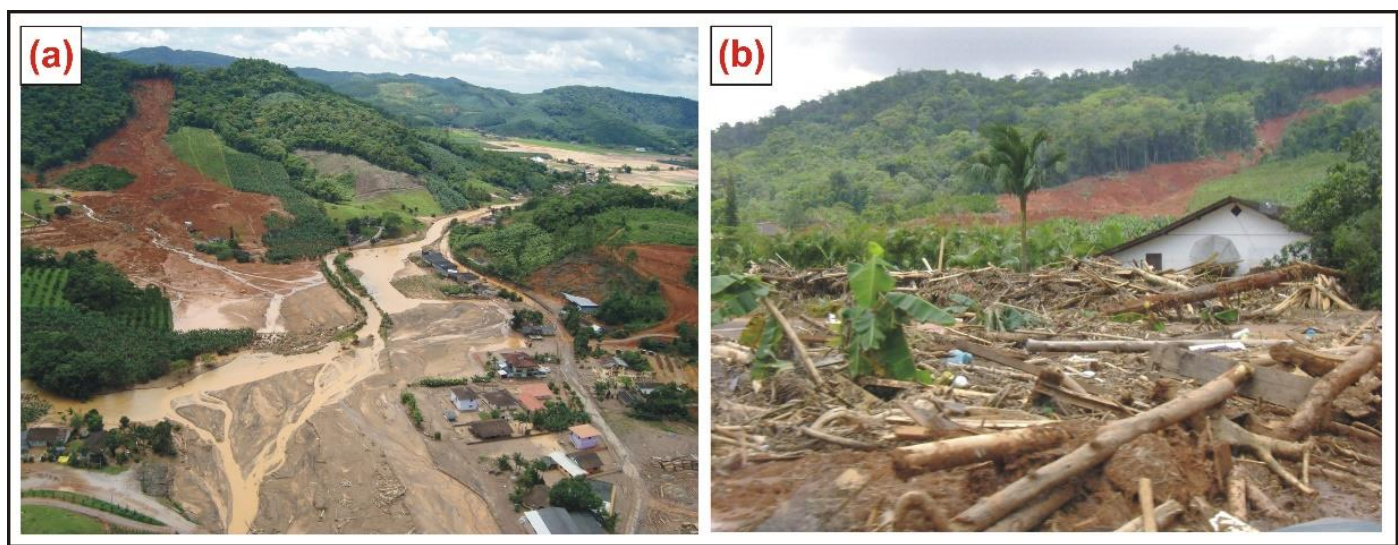

Fonte: Faria et al. (2008) (a) e Gramani, M. F. (b).

Em 2011, novamente na Serra do Mar, porém no Estado do Rio de Janeiro, volumes pluviométricos elevados deflagraram escorregamentos e corridas de detritos em seis municípios, com destaque para Nova Friburgo, Petrópolis e Teresópolis. Forma mais de 1.000 mortos, 15.000 desaparecidos e 20.000 desabrigados, tornando-se até aquele momento o pior evento no Brasil (AVELAR et al., 2013; KANJI et al., 2017; VIEIRA; GRAMANI, 2015) (Figura 2.13).

Figura 2.13: Desastre ocorrido em 2011, na Região Serrana do Rio de Janeiro. Depósito de corridas de detritos, em Teresópolis/RJ (a); Destaque para percurso realizado por corrida de detritos, na bacia do Rio Vieira, em Teresópolis/RJ (b).

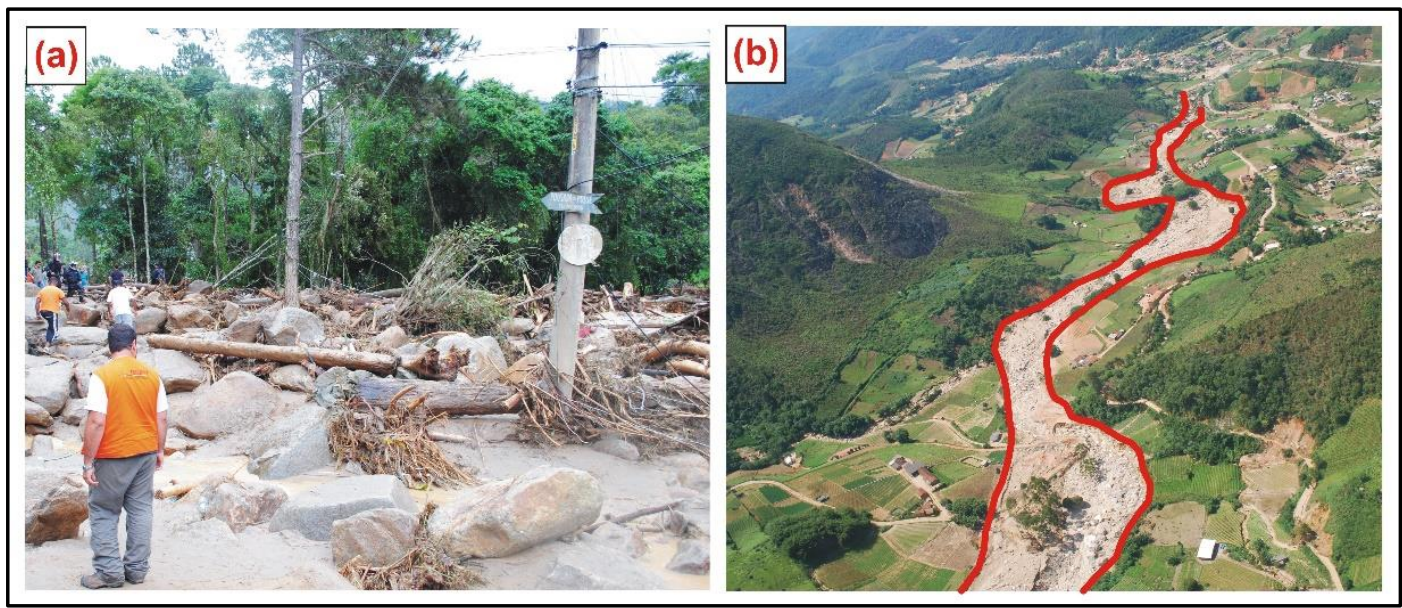

Fonte: DRM (a) GPmorfo (b). 
Também no verão de 2011, a região da Serra da Prata foi atingida por elevados volumes pluviométricos, cerca de $120 \mathrm{~mm}$, que deflagraram escorregamentos e corridas de detritos no dia 11 de março nos municípios de Antonina, Morretes e Paranaguá. Segundo Picanço e Nunes (2013), alguns pluviômetros marcaram $500 \mathrm{~mm}$ de volume acumulado três dias antes do evento, demonstrando que, apesar do volume do evento deflagrador ter sido "menor", as chuvas antecedentes tiveram um papel central na deflagração dos processos. Houve danos às propriedades, destruição parcial ou total de casas, estradas, pontes e lavouras, pessoas feridas, milhares de desabrigados e 4 mortos (KANJI et al., 2017; PICANÇO et al., 2016).

Apesar desta ocorrência não possuir o mesmo nível de devastação e perda de vidas humanas que a tragédia na Região Serrana do Rio de Janeiro, ocorrida no mesmo ano, o evento na Serra da Prata chama a atenção devido ao volume de materiais mobilizado pelas corridas de detritos e pelas características dos depósitos. Segundo Picanço et al. (2016), a maior parte das corridas de detritos ocorreu nas bacias dos rios Jacareí, Santa Cruz e Miranda, onde foram identificados depósitos compostos por blocos com mais de $10 \mathrm{~m}$ que entulharam o leito de rios, causando grande modificação na paisagem local (Figura 2.14).

Figura 2.14: Ocorrência na região da Serra da Prata. (a): Visão geral do depósito de corridas de detritos; (b): Detalhe para o tamanho dos blocos comparados à escala humana (círculo) e aos sedimentos finos depositados sobre os blocos (setas).

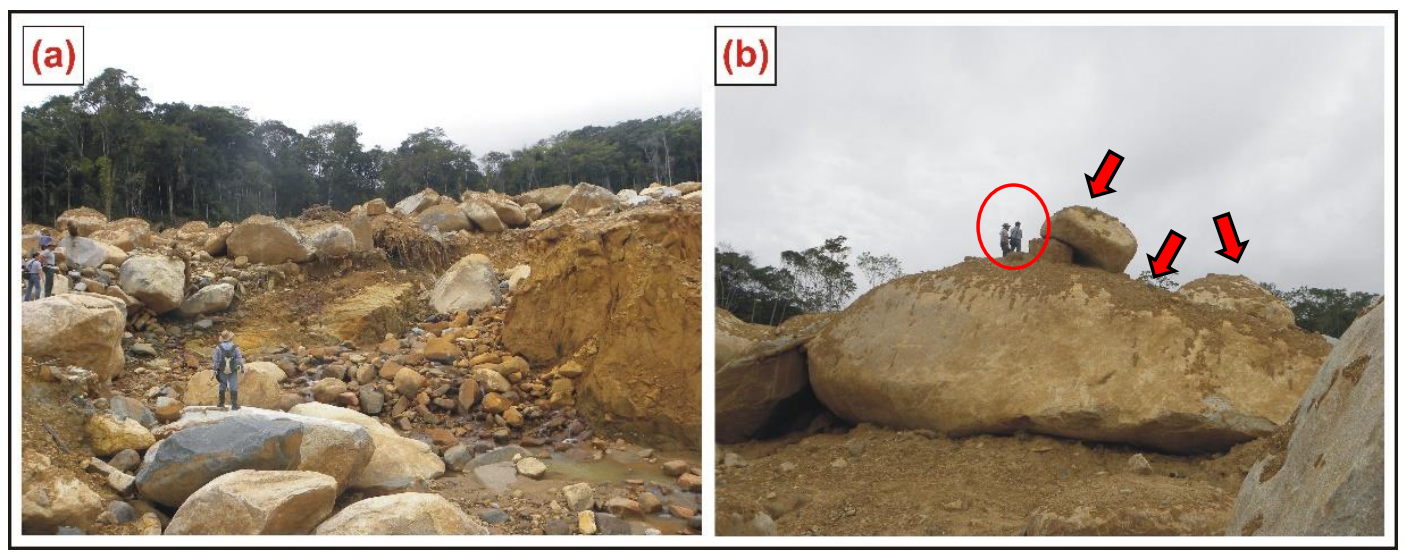

Fonte: GPmorfo.

No dia 13 de janeiro de 2014 o município de Itaoca foi atingido por um elevado volume pluviométrico, que culminou com a deflagração de escorregamentos e corridas de detritos que devastaram o pequeno centro urbano do município (Figura 2.15). Estima-se que o volume total deflagrado em apenas 2 horas tenha sido de aproximadamente 200 mm (GRAMANI; MARTINS, 2016); no entanto, a única estação meteorológica instalada na área central da cidade marcou apenas $18 \mathrm{~mm}$ em 12/01/2014 (BROLLO et al., 2015). Devido aos danos causados, as 
autoridades locais decretaram estado de calamidade pública, com o registro de 25 mortes, 3 desaparecidos e 203 afetados entre desabrigados e desalojados, além dos danos às infraestruturas (interrupção do sistema de energia elétrica, telefone e destruição de estação da SABESP) (GRAMANI, 2015).

Figura 2.15: Ocorrência no município de Itaoca/SP, em 2014. (a): Residência destruída em porção central do município; (b): Depósito de corridas de detritos.

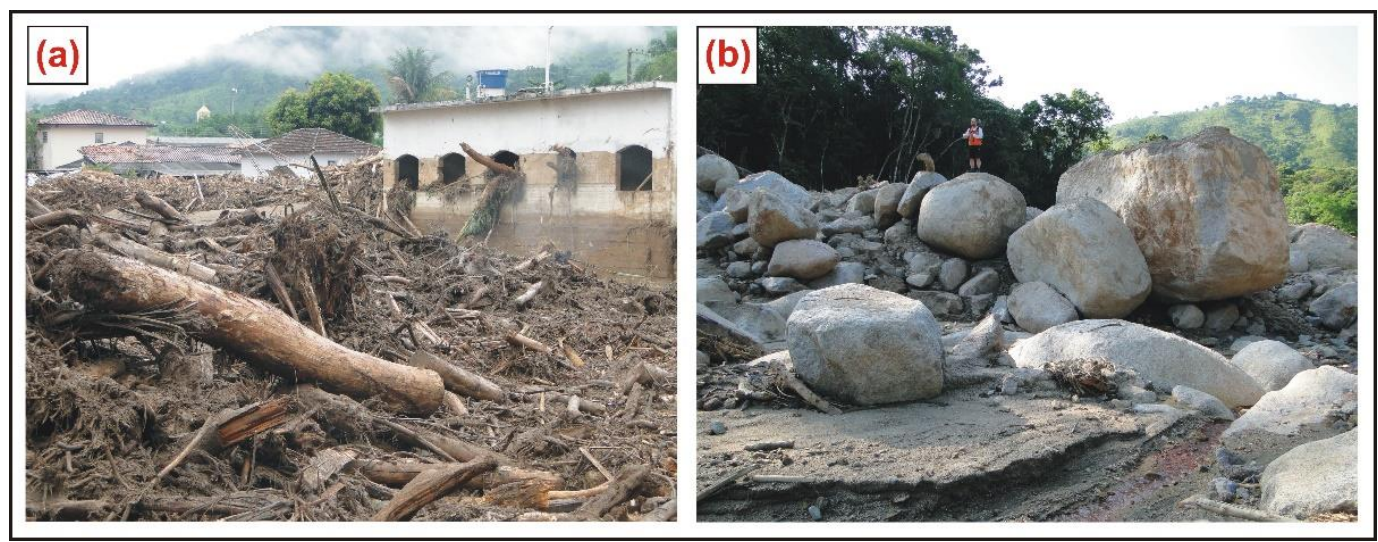

Fonte: Prefeitura Municipal de Itaoca (a); Gramani, M. F. (b).

Dada a proporção do evento na Região Serrana do Rio de Janeiro, as autoridades federais estabeleceram a Política Nacional de Proteção e Defesa Civil na forma da Lei $\mathrm{N}^{\mathrm{O}}$ 12.608 de 10 de abril de 2012, como forma de remediar possíveis novas ocorrências, possuindo como principais diretrizes:

I - Atuação articulada entre a União, os Estados, o Distrito Federal e os Municípios para redução de desastres e apoio às comunidades atingidas;

II - Abordagem sistêmica das ações de prevenção, mitigação, preparação, resposta e recuperação;

III - A prioridade às ações preventivas relacionadas à minimização de desastres;

IV - Adoção da bacia hidrográfica como unidade de análise das ações de prevenção de desastres relacionados a corpos d'água;

V - Planejamento com base em pesquisas e estudos sobre áreas de risco e incidência de desastres no território nacional;

VI - Participação da sociedade civil. ${ }^{4}$

Foram criadas novas instituições como o CEMADEN (Centro Nacional de Monitoramento e Alerta de Desastres Naturais), cujo principal objetivo é o monitoramento climático visando identificar e alertar sobre a possibilidade de ocorrência de desastres em áreas de risco, além do estabelecimento de articulações entre instituições já existentes (IPT, IG,

\footnotetext{
${ }^{4}$ Fonte: http://www.planalto.gov.br/ccivil_03/_Ato2011-2014/2012/Lei/L12608.htm
} 
CPRM, etc.), visando a identificação e mapeamento de áreas de risco não só na região da Serra do Mar, mas também nos municípios de todo o Brasil.

Dessa forma, mapeamentos de suscetibilidade a processos de movimentos de massa, inundações e enxurradas foram elaborados pela CPRM para municípios em todo território nacional. Ao todo, foram elaboradas 526 cartas municipais de suscetibilidade no período de 2012-20215 , com destaque para São Paulo (104) e Rio de Janeiro (92), Estados com o maior número de ocorrências de desastres naturais no país.

Tais medidas proporcionaram uma maior articulação entre governo federal, estados e municípios, além do incentivo à realização e pesquisas nos diversos centros universitários visando a identificação de áreas suscetíveis à ocorrência de diferentes processos, além da ampliação dos conhecimentos a respeito de tipologias ainda difíceis de serem mapeadas, como as corridas de detritos, buscando sempre a ampliação dos conhecimentos a respeito dos diferentes tipos de processos, contribuindo, assim, para a elaboração de planos de prevenção e contenção. À vista disso, com relação à 2011, o país encontra-se mais bem preparado para lidar com possíveis ocorrências de desastres naturais, no entanto, ressalta-se a importância da continuidade de tais estudos e parcerias, almejando o mapeamento da totalidade dos municípios do país, abarcando os diferentes tipos de processos a que eles podem estar sujeitos.

\footnotetext{
${ }^{5}$ Fonte: http://www.cprm.gov.br/publique/Gestao-Territorial/Prevencao-de-Desastres/Produtos-por-Estado--Cartas-de-Suscetibilidade-a-Movimentos-Gravitacionais-de-Massa-e-Inundacoes-5384.html
} 


\subsection{Métodos de previsão e avaliação de suscetibilidade e frequência}

Dada às suas características anteriormente citadas, as corridas de detritos são um dos processos com maior potencial destrutivo quando associado às áreas ocupadas. Diferentes métodos têm sido empregados por pesquisadores de diferentes partes do mundo com o objetivo de prever e remediar ocorrências (BORGA et al., 2014; HUEBL; FIEBIGER, 2005; JAKOB; OWEN; SIMPSON, 2012; LEE; WINTER, 2019; STOFFEL, 2010; WELSH; DAVIES, 2011; WILFORD et al., 2004).

Suscetibilidade é o termo utilizado para definir a possibilidade de ocorrência de determinado processo geológico em uma área, ou seja, uma área é identificada como suscetível se ela apresenta características que evidenciam e viabilizam a possibilidade de ocorrência de determinado processo (CERRI; AMARAL, 1998). No caso das corridas de detritos, por estas se tratarem de um processo hidrodinâmico, as características das bacias hidrográficas, evidenciadas pelos parâmetros morfométricos, assim como a presença de feições características da ocorrência do processo (ex. depósitos; marcações nos troncos das árvores), fornecem indícios da suscetibilidade da bacia à ocorrência do processo (JAKOB, 2005a).

A identificação de áreas suscetíveis pode ser feita primeiramente por meio da verificação das características geológicas e geomorfológicas da bacia, ou seja, se a área possui, por exemplo, encostas íngremes (ângulo acima de $25^{\circ}$ ) e disponibilidade de sedimentos/materiais para transporte, além de fonte abundante de água (ex. elevados índices pluviométricos). Em seguida, deve-se observar evidências da recorrência do processo, que podem ser verificadas pela presença de depósitos característicos.

A análise dendrocronológica, que verifica os anéis de crescimentos dos troncos das árvores, cuja presença de anomalias de crescimentos, combinado a registros climáticos extremos, pode indicar se a árvore em questão sofreu um grande impacto por detritos (Figura 2.16) (JAKOB, 1996; STOFFEL, 2010). Tal método é comumente utilizado no hemisfério norte, onde as corridas de detritos ocorrem majoritariamente nas encostas (deflagradas a partir da transformação dos escorregamentos em corridas de detritos por meio da liquefação). No caso, a magnitude menor das corridas propicia a permanência das árvores, que são marcadas pelo processo (Figura 2.17). Devido à magnitude e à tipologia das corridas no Brasil, é difícil encontrar árvores que possam ser avaliadas por meio de uma análise dendrocronológica, uma vez que elas são arrancadas e mobilizadas pelas corridas. Outro ponto a ser verificado é a ausência de um banco de dados de longo prazo que contenha informações exatas a respeito de eventos climáticos extremos no país. 
Figura 2.16: Esquema explicativo da análise dendrocronológica. Os troncos das árvores atingidas pelas corridas de detritos sofrem alterações em seu interior, impactando o crescimento dos anéis internos do mesmo.

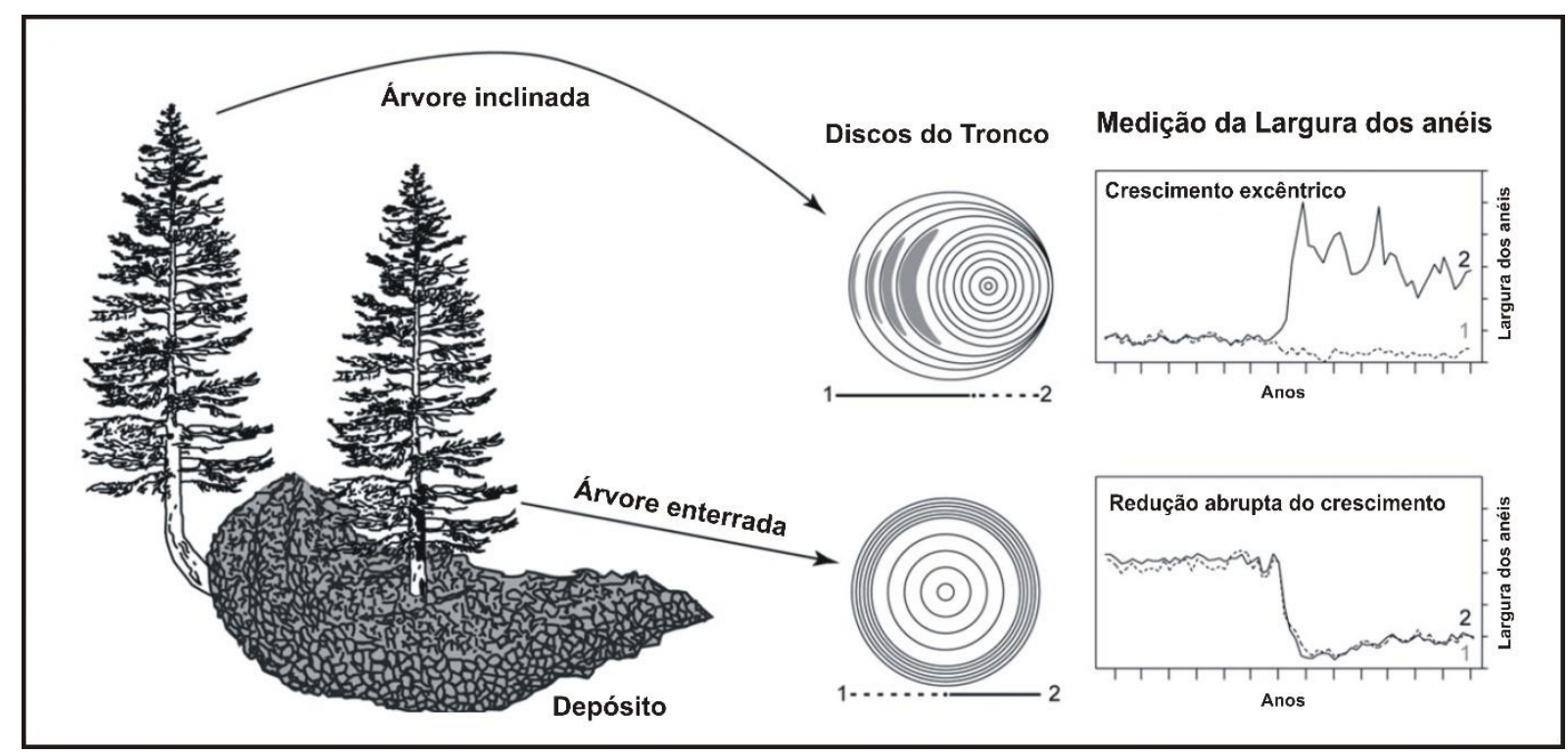

Fonte: adaptado de Stoffel (2010).

Figura 2.17: Árvores semi soterradas por corridas de detritos em Lillooet, Canadá. (a): árvore com troco enterrado e possivelmente com sinais de inclinação nos discos do tronco; (b): sequência de árvores enterradas por corridas de detritos.

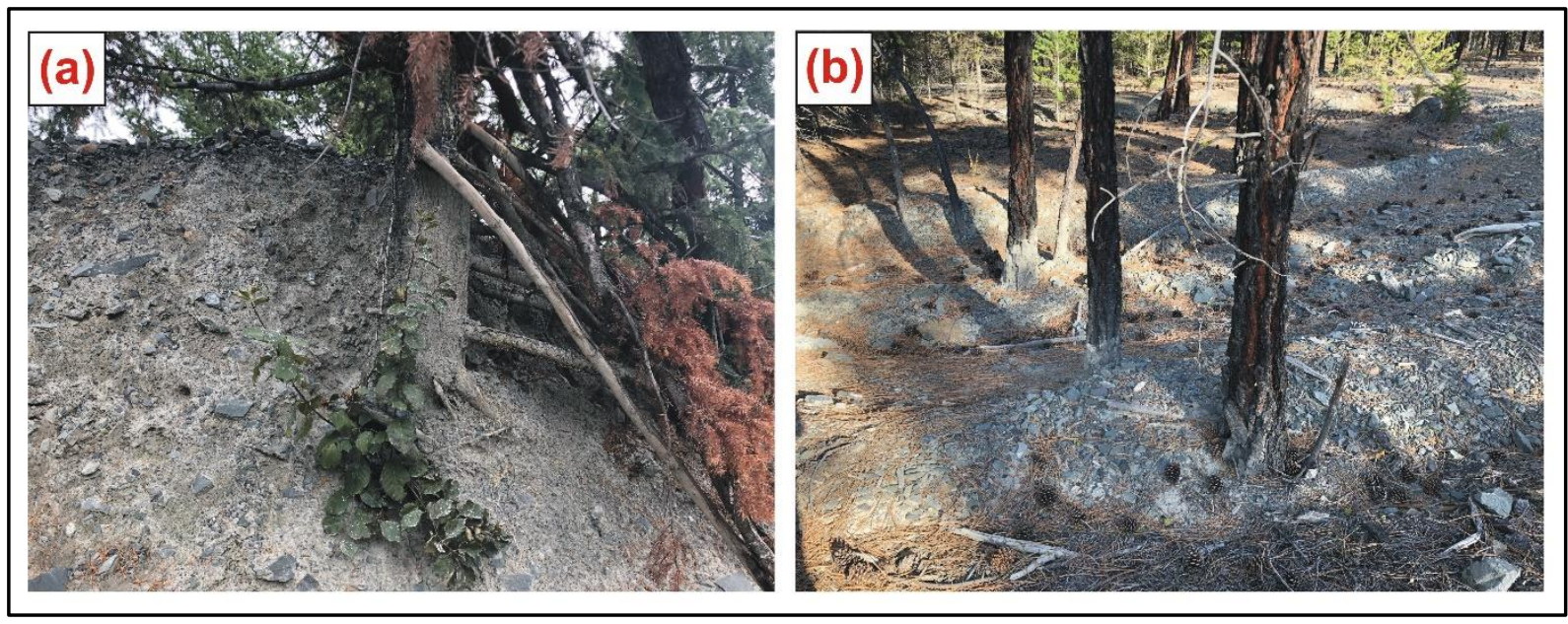

Métodos ligados à previsão de corridas de detritos estão, em sua maioria, relacionados ao volume pluviométrico necessário para deflagrá-lo. Em Vancouver (Canadá) as áreas suscetíveis às corridas de detritos são identificadas após ocorrência de chuvas de grande intensidade, por meio de trabalhos de campo e sobrevoos. Sua ocorrência é verificada a partir dos depósitos e as informações são cadastradas em um banco de dados. Tal procedimento é realizado mesmo não havendo danos às infraestruturas, como medida de prevenção. A cidade 
possui registros de ocorrências de 21 anos, informando as bacias com ocorrência e o volume pluviométrico associado. Tais dados foram trabalhados estatisticamente para determinação de possíveis cenários mais propensos ou não a ocorrência de corridas de detritos, e propiciaram a elaboração de um sistema de alerta para corridas de detritos potenciais em tempo real durante o período chuvoso (JAKOB; OWEN; SIMPSON, 2012).

Borga et al. (2014), no entanto, ressaltam que, além do fator pluviométrico, o processo depende de inúmeras variáveis, dentre elas, características hidrológicas, morfológicas e geotécnicas das encostas, da fonte dos materiais e a disponibilidade de sedimentos. Os autores enfatizam que as corridas de detritos, em geral, iniciam-se em bacias pequenas, no entanto, o transporte e a deposição do processo podem impactar áreas muito maiores. Da mesma forma, com relação à previsão por meio da utilização de limites críticos de chuva, o intervalo entre a ocorrência da precipitação e a deflagração do processo pode variar de acordo com as características específicas da chuva, volume anterior acumulado e a morfometria da bacia afetada.

Sendo um processo que possui como fator determinante relevos íngremes, a previsão e monitoramento são muito difíceis. Para correta medição é necessário um sistema capaz de medir a chuva com alta resolução temporal e espacial, e muitas vezes, as redes de medição da precipitação não são densas o suficiente para reproduzir a variabilidade espacial (BORGA et al., 2014; WIECZOREK; GLADE, 2005). Mesmo em áreas com uma densa rede de medição, como é o caso dos Alpes Europeus, o espaçamento típico entre cada estação de medição é de $10 \mathrm{~km}$, enquanto a distribuição de chuvas possui variação menor do que $10 \mathrm{~km}$. A Figura 2.18 demonstra justamente esta variabilidade ao mostrar as áreas onde as corridas de detritos foram deflagradas e a localização dos medidores, que muitas vezes estão localizados muito longe das zonas deflagradoras, em áreas mais planas e baixas do relevo (BORGA et al., 2014). 
Figura 2.18: Mapa derivado de medição por meio de radar para três eventos deflagradores de corridas de detritos, destacando a localização dos processos (círculos) e a localização dos medidores (triângulos).

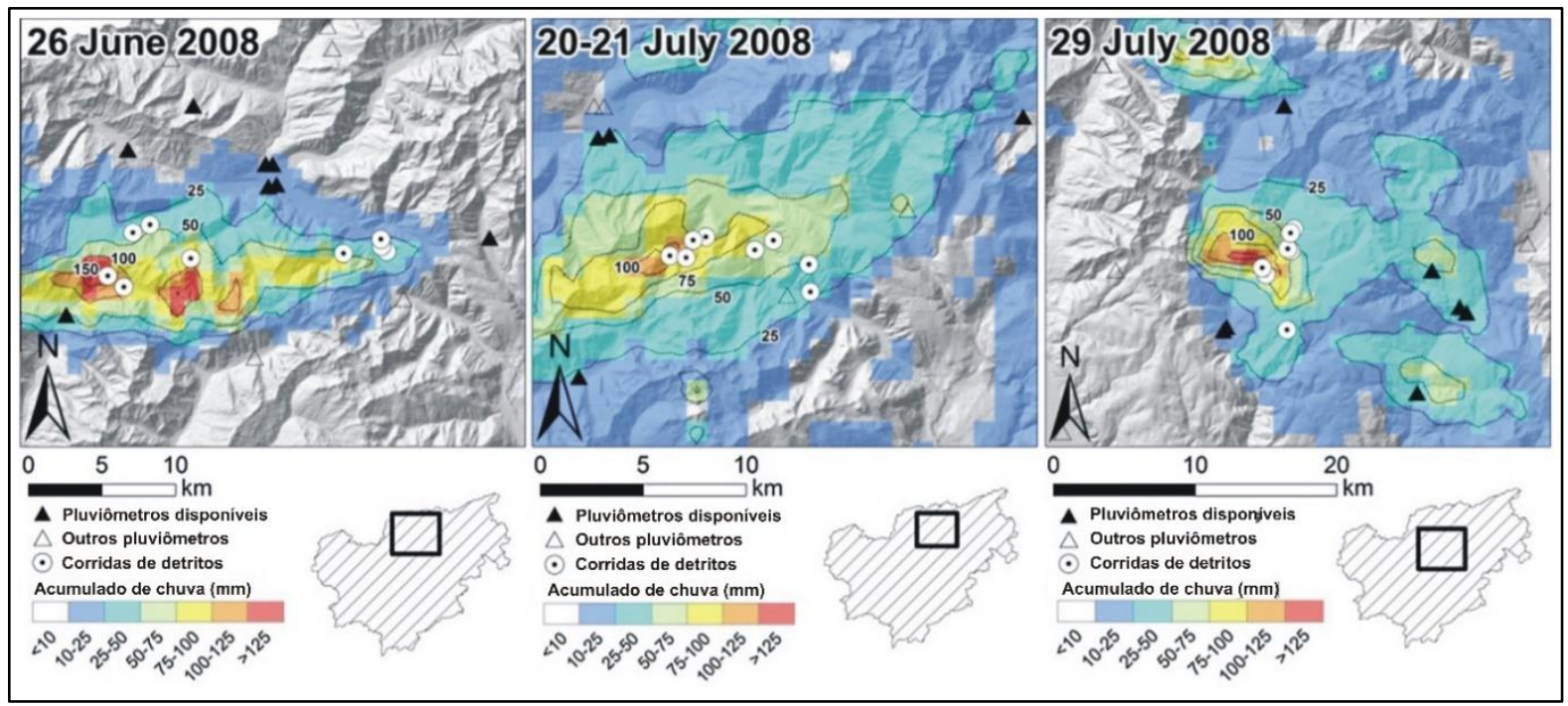

Fonte: modificado de Borga et al. (2014).

Marra et al. (2014) apontam como possível solução o uso de radares meteorológicos (sensoriamento remoto), capazes de fornecer medições de chuva mais extensivas em tempo real, em localidades específicas e em resolução de espaço e tempo que permitiria o monitoramento dos processos. No Brasil, o monitoramento de chuvas se dá majoritariamente por pluviômetros automáticos, uma vez que a cobertura feita por radar meteorológico realizada pelo CEMADEN ainda é muito pouco abrangente. Trata-se também de um método ainda difícil de ser utilizado devido às características do relevo montanhoso, pensando nas corridas de detritos, que ainda possuem um agravante: é necessário verificar nas áreas suscetíveis se há o suprimento de sedimentos ou verificar também a suscetibilidade à escorregamentos, uma vez que, mesmo com um evento climático extremo, se não houver suprimento de material, as corridas de detritos não ocorrerão (BORGA et al., 2014).

Neste sentido, a análise morfométrica de bacias vem sendo utilizada para a avaliação da suscetibilidade de bacias à ocorrência de corridas de detritos em várias escalas, desde a identificação da propensão da bacia à ocorrência do processo, até a avaliação da disponibilidade de sedimentos e magnitude (Tabela 2.3) (ARANGO; ARISTIZÁBAL; GÓMEZ, 2021; AUGUSTO FILHO, 1993; CERRI et al., 2018; CHEN; YU, 2011; DE SCALLY; SLAYMAKER; OWENS, 2001; DIAS; VIEIRA; GRAMANI, 2016; GOMES, 2016; ILINCA, 2021; JACKSON; KOSTASCHUK; MACDONALD, 1987; JAKOB, 1996; KANJI; GRAMANI, 2001; NIKOLOVA; KAMBUROV; RIZOVA, 2020; PICANÇO et al., 2016; VIEIRA et al., 1997; WELSH; DAVIES, 2011; WILFORD et al., 2004; ZHANG et al., 2015). 
Tabela 2.3: Utilização de parâmetros morfométricos no estudo de corridas de detritos.

\begin{tabular}{|c|c|c|}
\hline AUTOR & OBJETIVO & PARÂMETROS UTILIZADOS \\
\hline VanDine (1985) & $\begin{array}{l}\text { Avaliação do processo e } \\
\text { magnitude. }\end{array}$ & Área da bacia. \\
\hline Slaymaker (1990) & Caracterização de bacias & Área da bacia, ângulo do canal. \\
\hline $\begin{array}{l}\text { Johnson; } \\
\text { McCuen; } \\
\text { Hromadka (1991) }\end{array}$ & $\begin{array}{l}\text { Estimativa de magnitude } \\
\text { e frequência. }\end{array}$ & $\begin{array}{l}\text { Hipsometria, relação de relevo, densidade de drenagem, } \\
\text { comprimento total dos canais, bifurcação, relação de } \\
\text { alongamento da bacia. }\end{array}$ \\
\hline $\begin{array}{l}\text { Marchi; Pasuto; } \\
\text { Tecca (1993) }\end{array}$ & $\begin{array}{l}\text { Avaliação do processo e } \\
\text { magnitude. }\end{array}$ & Área e índice de Melton. \\
\hline $\begin{array}{l}\text { Augusto Filho } \\
\text { (1993) }\end{array}$ & $\begin{array}{l}\text { Hierarquização e } \\
\text { avaliação de } \\
\text { potencialidade de } \\
\text { geração de corridas. }\end{array}$ & $\begin{array}{l}\text { Área da bacia, índice de circularidade, densidade de } \\
\text { drenagem. }\end{array}$ \\
\hline Jakob (1996) & $\begin{array}{l}\text { Estimativa de magnitude } \\
\text { e frequência. }\end{array}$ & $\begin{array}{l}\text { Área da bacia, índice de rugosidade, hipsometria, densidade } \\
\text { de drenagem, índice de circularidade. }\end{array}$ \\
\hline Vieira et al. (1997) & Análise de magnitude. & $\begin{array}{l}\text { Assimetria/simetria do canal, perfil longitudinal, } \\
\text { comprimento do canal, hierarquia. }\end{array}$ \\
\hline $\begin{array}{l}\text { Cenderelli; Steven } \\
\text { Kite (1998) }\end{array}$ & $\begin{array}{l}\text { Avaliação do processo e } \\
\text { magnitude. }\end{array}$ & $\begin{array}{l}\text { Área, densidade de drenagem, forma da bacia, amplitude } \\
\text { altimétrica, relação de relevo, comprimento e ângulo. }\end{array}$ \\
\hline $\begin{array}{l}\text { De Scally; } \\
\text { Slaymaker; } \\
\text { Owens }(2001)\end{array}$ & $\begin{array}{l}\text { Análise e identificação } \\
\text { do processo. }\end{array}$ & Área da bacia, amplitude altimétrica, índice de rugosidade. \\
\hline $\begin{array}{l}\text { Marchi; Arattano; } \\
\text { Deganutti (2002) }\end{array}$ & $\begin{array}{l}\text { Avaliação do processo e } \\
\text { magnitude. }\end{array}$ & Área e índice de Melton. \\
\hline $\begin{array}{l}\text { Kanji; Gramani } \\
(2001)\end{array}$ & $\begin{array}{l}\text { Avaliação de } \\
\text { suscetibilidade. }\end{array}$ & Declividade, ângulo. \\
\hline $\begin{array}{l}\text { Wilford et al. } \\
\text { (2004) }\end{array}$ & $\begin{array}{l}\text { Diferenciação de } \\
\text { processos de tipo fluxo. }\end{array}$ & $\begin{array}{l}\text { Área da bacia, comprimento da bacia, formato, } \\
\text { comprimento dos canais, densidade de drenagem, } \\
\text { amplitude altimétrica, ângulo acima de } 30^{\circ}, 35^{\circ} \text { ou } 40^{\circ} \text {, } \\
\text { índice de Melton, relação de relevo. }\end{array}$ \\
\hline $\begin{array}{l}\text { Gabet; Bookter, } \\
(2008)\end{array}$ & $\begin{array}{l}\text { Análise do processo e } \\
\text { magnitude. }\end{array}$ & Área e ângulo. \\
\hline $\begin{array}{l}\text { Kovanen; } \\
\text { Slaymaker (2008) }\end{array}$ & $\begin{array}{l}\text { Análise do processo e } \\
\text { magnitude. }\end{array}$ & Área da bacia, índice de Melton. \\
\hline $\begin{array}{l}\text { De Scally; Owens; } \\
\text { Louis (2010) }\end{array}$ & $\begin{array}{l}\text { Avaliação de } \\
\text { suscetibilidade. }\end{array}$ & $\begin{array}{l}\text { Área, relação de relevo, comprimento da bacia, amplitude } \\
\text { altimétrica e índice de Melton. }\end{array}$ \\
\hline $\begin{array}{l}\text { Portilla; } \\
\text { Chevalier; } \\
\text { Hürlimann (2010) }\end{array}$ & $\begin{array}{l}\text { Avaliação de } \\
\text { suscetibilidade. }\end{array}$ & $\begin{array}{l}\text { Área, ângulo do canal, amplitude altimétrica e índice de } \\
\text { Melton. }\end{array}$ \\
\hline $\begin{array}{l}\text { Welsh; Davies } \\
\text { (2011) }\end{array}$ & $\begin{array}{l}\text { Diferenciação de } \\
\text { processos de tipo fluxo. }\end{array}$ & Comprimento do canal; índice de Melton. \\
\hline Chen; Yu (2011) & $\begin{array}{l}\text { Análise do processo e } \\
\text { magnitude. }\end{array}$ & $\begin{array}{l}\text { Relação de relevo, índice de rugosidade, fator de forma, } \\
\text { ângulo, índice de potencial erosivo do canal, índice de } \\
\text { caracterização do terreno, índice topográfico de umidade. }\end{array}$ \\
\hline $\begin{array}{l}\text { Simoni; } \\
\text { Mammoliti; Berti } \\
\text { (2011) }\end{array}$ & $\begin{array}{l}\text { Avaliação de } \\
\text { suscetibilidade. }\end{array}$ & Área e comprimento da bacia. \\
\hline $\begin{array}{l}\text { Picanço et al. } \\
(2016)\end{array}$ & $\begin{array}{l}\text { Avaliação de } \\
\text { suscetibilidade. }\end{array}$ & Índice de Melton. \\
\hline $\begin{array}{l}\text { Dias; Vieira; } \\
\text { Gramani (2016); } \\
\text { Dias (2017) }\end{array}$ & Avaliação de magnitude. & $\begin{array}{l}\text { Área da bacia, índice de rugosidade, relação de relevo, } \\
\text { densidade de drenagem, índice de circularidade, hierarquia, } \\
\text { curvatura, ângulo. }\end{array}$ \\
\hline Gomes (2016) & Avaliação de magnitude. & $\begin{array}{l}\text { Área, índice de rugosidade, hierarquia de drenagem, índice } \\
\text { de potencial erosivo do canal, índice topográfico de } \\
\text { umidade, relação de relevo, densidade de drenagem, } \\
\text { amplitude altimétrica, declividade média do canal, área } \\
\text { acima de } 30^{\circ} \text { e fator topográfico. }\end{array}$ \\
\hline
\end{tabular}




\begin{tabular}{|c|c|c|}
\hline Cerri et al. (2018) & $\begin{array}{l}\text { Avaliação de } \\
\text { suscetibilidade. }\end{array}$ & $\begin{array}{l}\text { Índice de circularidade, índice de rugosidade, densidade de } \\
\text { drenagem, relação de relevo, índice de Melton. }\end{array}$ \\
\hline $\begin{array}{l}\text { Lima; Fernandes; } \\
\text { Vargas Junior, } \\
\text { (2020) }\end{array}$ & $\begin{array}{l}\text { Avaliação de } \\
\text { suscetibilidade. }\end{array}$ & $\begin{array}{l}\text { Ângulo de encosta, índice topográfico de umidade, índice } \\
\text { de potência unitária de corrente e fator topográfico. }\end{array}$ \\
\hline Zubrycky (2020) & $\begin{array}{l}\text { Avaliação do processo e } \\
\text { magnitude. }\end{array}$ & $\begin{array}{l}\text { Área, ângulo do canal, amplitude altimétrica e índice de } \\
\text { Melton. }\end{array}$ \\
\hline $\begin{array}{l}\text { Nikolova; } \\
\text { Kamburov; } \\
\text { Rizova (2020) }\end{array}$ & $\begin{array}{l}\text { Avaliação de } \\
\text { suscetibilidade. }\end{array}$ & $\begin{array}{l}\text { Área, amplitude altimétrica, relação de relevo, } \\
\text { comprimento da bacia, índice de Melton, ângulo, índice de } \\
\text { potencial erosivo do canal, índice topográfico de umidade. }\end{array}$ \\
\hline $\begin{array}{l}\text { Dotseva; } \\
\text { Gerdjikov (2020) }\end{array}$ & $\begin{array}{l}\text { Avaliação de } \\
\text { suscetibilidade. }\end{array}$ & $\begin{array}{l}\text { Área, densidade de drenagem, relação de relevo, índice de } \\
\text { Melton, fator de forma. }\end{array}$ \\
\hline $\begin{array}{l}\text { Arango; } \\
\text { Aristizábal; } \\
\text { Gómez (2021) }\end{array}$ & $\begin{array}{l}\text { Avaliação de } \\
\text { suscetibilidade. }\end{array}$ & $\begin{array}{l}\text { Ordem do canal principal, número de canais, comprimento } \\
\text { dos canais, comprimento do canal principal, índice de } \\
\text { comprimento de canal, índice de bifurcação, comprimento } \\
\text { da bacia, área, perímetro, fator de forma, índice de } \\
\text { alongamento, índice de circularidade, coeficiente de } \\
\text { capacidade, índice de textura, frequência de canais, } \\
\text { densidade de drenagem, coeficiente de manutenção de } \\
\text { canais, densidade de intensidade, amplitude altimétrica, } \\
\text { ângulo, relação de relevo, índice de rugosidade, índice de } \\
\text { Melton. }\end{array}$ \\
\hline Ilinca (2021) & $\begin{array}{l}\text { Diferenciação de } \\
\text { processos de tipo fluxo. }\end{array}$ & $\begin{array}{l}\text { Área, índice de Melton, relação de relevo, comprimento da } \\
\text { bacia. }\end{array}$ \\
\hline Coe et al. (2021) & $\begin{array}{l}\text { Avaliação de } \\
\text { suscetibilidade. }\end{array}$ & Área, índice de Melton, Área da bacia $>30^{\circ}$. \\
\hline
\end{tabular}

Dentre os diversos parâmetros, alguns se destacam no estudo das corridas de detritos e na representatividade de seus resultados, uma vez que demonstram que características de uma bacia hidrográfica podem influenciar na ocorrência do processo, como maior disponibilidade de materiais/sedimentos, maior escoamento, e potencial de transporte. Outros, no entanto, apresentam resultados genéricos quando utilizados para avaliação específica de corridas de detritos.

Para a identificação de bacias suscetíveis, o Índice de Melton $(M)$ (Equação 2.1) vem sendo utilizado por diferentes autores para a identificação de processos predominantes em bacias hidrográficas, com destaque às corridas de detritos (CERRI et al., 2018; ILINCA, 2021; PICANÇO et al., 2016; WELSH; DAVIES, 2011; WILFORD et al., 2004). Segundo Welsh; Davies (2011), trata-se de um método útil, sobretudo quando as investigações em campo não detectam evidências das corridas de detritos ou até mesmo, quando os investigadores não estão familiarizados com processos geomorfológicos e sua identificação em campo. Ressalta-se ainda que tais evidências tendem a desaparecer da paisagem ao longo do tempo, especialmente devido ao crescimento da vegetação, o que pode contribuir para a errônea classificação de uma área como não suscetível ao processo, uma vez que a ausência de evidências físicas não significa que o processo nunca ocorreu na área em questão. 
Equação 2.1:Índice de Melton.

$$
M=\mathrm{H} / \sqrt{ } A
$$

Na qual:

$H$ : amplitude altimétrica $(\mathrm{km})$;

$A$ : área da bacia $\left(\mathrm{m}^{2}\right)$.

Segundo o valor dado pelo índice, é possível classificar a bacia com geradora ou não de corridas de detritos da seguinte maneira:

- $\mathrm{R}</=0.30$ : processos fluviais predominam na bacia;

- $0.30>\mathrm{R}<$ 0.60: processos do tipo enxurradas predominam na bacia; $\mathrm{e}$

- $\mathrm{R}>$ 0.60: bacias com possibilidade ou predomínio de corridas de detritos.

Apesar de ser um método comprovadamente válido na identificação de bacias suscetíveis, Welsh; Davies (2011) enfatizam que as corridas de detritos são processos complexos que exigem análise de outros fatores controladores como topologia, litologia e clima, não dependendo exclusivamente do Índice de Melton. Tais fatores podem influenciar no resultado do método, sendo recomendado a sua aplicação em áreas que possuam topografia semelhante para avaliação.

Assim como o $M$, a Área da bacia $(A)$ também é utilizada para avaliar a possibilidade de ocorrência de corridas de detritos. No caso, os autores têm como referencial o tamanho da bacia, afirmando que o processo é mais propenso a ocorrer em bacias até $10 \mathrm{Km}^{2}$ (DOTSEVA; GERDJIKOV, 2020; ILINCA, 2021; JOHNSON; MCCUEN; HROMADKA， 1991; SLAYMAKER, 1990; THURBER CONSULTANTS LTD., 1983; VANDINE, 1985). No entanto, é importante diferenciar a bacia onde o processo se inicia de seu atingimento total, uma vez que, apesar de ser mais frequente a sua iniciação em bacias de primeira ordem, as corridas de detritos podem chegar até o canal principal, ou até mesmo se iniciar no canal principal, atingindo uma área muito maior do que $10 \mathrm{~km}^{2}$. Sendo, neste caso, influenciada pelas características morfométricas da bacia e sendo, no caso brasileiro, mais recorrente. Neste sentido, apesar dos bons resultados, em especial no hemisfério norte, a determinação da suscetibilidade a partir destes parâmetros necessita de outros métodos de suporte para maior acurácia, tal como a identificação de ocorrências pretéritas, avaliação de registros históricos e utilização de outros parâmetros em conjunto para melhor caracterização morfométrica da bacia.

Outros parâmetros como Densidade de drenagem $(D d)$ (Equação 2.2), Hierarquia de drenagem $(H d)$ (Equação 2.3) e Comprimento dos canais $(\mathrm{Cc})$ demonstram o potencial de 
escoamento da bacia, fator este que contribui para a maior ou menor magnitude de processos no que diz respeito ao transporte de sedimentos. No caso da $D d$, bacias mais densas terão um escoamento mais rápido, contribuindo para ocorrências de processos hidrodinâmicos, tais como enxurradas e corridas de detritos, e, cheias relampados. Já com relação à $H d$, quanto maior a hierarquia da bacia, maior o número de tributários que contribuirão para o escoamento da bacia, sobretudo no canal principal. O $C c$ diz respeito ao comprimento total dos tributários que compõe a bacia, possuindo um resultado semelhante à $H d$, ou seja, quanto maior o $C c$, maior seria o potencial de escoamento da bacia (CHRISTOFOLETTI, 1980; HORTON, 1945; SHREVE, 1966, 1967). Já o Índice de caracterização do terreno (TCI) (Equação 2.4) busca também demonstrar a capacidade de transporte da bacia, porém, a partir de uma relação entre curvatura e área de contribuição à montante.

Equação 2.2: Densidade de drenagem.

$$
D d=\frac{L_{t}}{A}
$$

Na qual:

$L_{t}$ : comprimento total dos canais (m);

A: área da bacia $\left(\mathrm{Km}^{2}\right)$.

Equação 2.3: Hierarquia de drenagem (Shreve)

$$
H d=\left(u_{1}+u_{1}\right)+u_{3} \ldots u_{5}
$$

Na qual:

$u$ : ligamento/canal.

Equação 2.4: Índice de caracterização do terreno

$$
T C I=k \operatorname{In} A s
$$

Na qual:

As: área de contribuição à montante;

$k$ : curvatura topográfica total.

Os parâmetros Índice de rugosidade (Ir) (Equação 2.5), Relação de relevo (Rr) (Equação 2.6) e Índice de potencial erosivo (SPI) (Equação 2.7) fornecem mais informações 
a respeito da possível disponibilidade e produção de sedimentos na bacia. Sendo uma relação entre a $D d$ e a declividade e comprimento das vertentes, o índice expressa a evolução da bacia no que diz respeito à maior ou menor produção de sedimentos. Bacias mais rugosas, tendem a possuir processos hidrodinâmicos mais intensos, sendo um resultado direto de uma densidade de drenagem elevada e encostas mais íngremes (STRAHLER, 1958). Neste sentido, o Ir elevado revelaria um maior potencial para geração de corridas de detritos, uma vez que a bacia possuiria propensão para processos mais intensos, assim como disponibilidade maior de sedimentos para transporte (DE SCALLY; SLAYMAKER; OWENS, 2001).

A $R r$ trata da relação entre a amplitude altimétrica da bacia e o seu comprimento, ou seja, quanto maior a variação altimétrica da bacia e o seu tamanho, mais intensos tendem a ser os processos hidrodinâmicos na bacia, sobretudo aqueles induzidos pela gravidade, como é o caso das corridas de detritos. Hadley; Schumm (1961) também apontaram a correlação entre a relação de relevo e a média anual de produção de sedimentos em bacias hidrográficas, indicando que quanto maior a produção de sedimentos, maior tende a ser os valores correspondentes à relação de relevo, o que favorece a maior disponibilidade de sedimentos para transporte nas bacias (Figura 2.19).

O SPI é utilizado para descrever o potencial de erosão e processos de evolução da paisagem do canal. Possui estrita relação com a declividade do canal, em resposta à ocorrencia de corridas de detritos, indicando que o fluxo em bacias mais íngrimes tendem a ter um maior poder erosivo para modificar rapidamente a paisagem. Este parâmetro possui alta correlação com o parâmetro Índice topográfico de umidade (TWI) (Equação 2.8), que demonstra as diferenças nos padrões de umidade do solo, sendo utilizado principalmente na avaliação de suscetibilidade à escorregamentos (CHEN; YU, 2011).

Equação 2.5: Índice de rugosidade.

$$
I r=H \cdot D d
$$

Na qual:

$H$ : amplitude altimétrica (m);

$D d$ : densidade de drenagem $(\mathrm{m} / \mathrm{km})$.

Equação 2.6: Relação de relevo.

$$
R r=\frac{H_{m}}{L_{h}}
$$


Na qual:

$H_{m}$ : amplitude altimétrica máxima (m);

$L_{h}$ : comprimento da bacia (m).

Figura 2.19: Relação entre média anual de acumulação de sedimentos e o parâmetro Relação de relevo, para o rio Chenney, em Dakota do Sul, Estado Unidos.

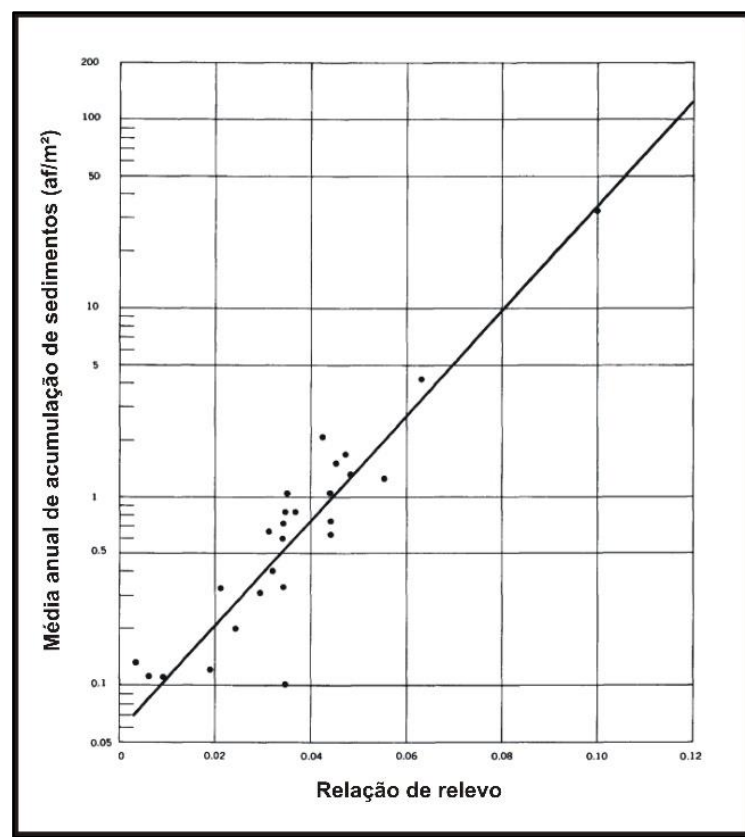

Fonte: modificado de Hadley; Schumm (1961).

Equação 2.7: Índice de potencial erosivo do canal

$$
S P I=\log (A \cdot \tan \beta)
$$

Na qual:

A: área de contribuição;

$\beta$ : declividade.

Equação 2.8: Índice topográfico de umidade

$$
T W I=\operatorname{In}(A s / \tan \beta)
$$

Na qual: 
A: área de contribuição;

$\beta$ : declividade.

O Perfil longitudinal $(P l)$ do rio principal da bacia é obtido a partir da relação entre comprimento do canal e sua topografia, gerando um gráfico que permite a avaliação de características específicas do canal, como rupturas de declives, verificação do gradiente altimétrico $(\Delta P l)$ do canal, ou seja, o quanto a altitude varia em determinada distância, e ângulo do canal. Observa-se que quanto maior o gradiente altimétrico, maior será a variação de altitude, proporcionando maior influência da gravidade no transporte e alcance dos processos na bacia. No caso das corridas de detritos, o gradiente altimétrico e ângulo das áreas de iniciação e transporte do canal exercem maior influência no processo, uma vez que, quanto maior o gradiente e ângulo, maiores são as chances de deflagração. Da mesma forma, o parâmetro Área acima de $25^{\circ}(A 25)$ avalia a porcentagem de área da bacia que se encontra em um ângulo acima de $25^{\circ}$. Quanto maior esta porcentagem, mais íngreme será a bacia, e, portanto, maior será a sua propensão à geração de corridas de detritos com maior alcance. O parâmetro Ângulo do canal (Ac) parte da mesma premissa, sendo mais representativo, no entanto, em bacias de zero ordem.

O Índice de circularidade (Ic) (Equação 2.9) é utilizado por diferentes autores para a indicação de áreas mais suscetíveis às corridas de detritos. Para Crozier (1986), as bacias com formato mais alongado (índice $<0,5$ ) seriam preferenciais para a ocorrência do processo, uma vez que, em relevo escarpado, o alongamento da bacia favoreceria a concentração do fluxo; já para Augusto Filho (1993), seriam as bacias arredondadas (índice > 0,5) as mais propensas à geração de corridas de detritos, onde tal forma favoreceria o maior escoamento nas bacias e a geração de cheias relâmpagos. Em sua avaliação, Dias (2017) não encontrou relação entre a magnitude das corridas de detritos e o parâmetro índice de circularidade (Figura 2.20), concluindo que ambos os formatos (alongado e circular) podem gerar corridas de detritos de maior ou menor magnitude, a depender de outras características morfométricas da bacia a ser estudada.

Equação 2.9: Índice de circularidade.

$$
I c=\frac{A}{A c}
$$

Na qual:

A: área da bacia $\left(\mathrm{m}^{2}\right)$; 
$A_{c}$ : área com perímetro igual ao da bacia $\left(\mathrm{m}^{2}\right)$.

Figura 2.20: Relação entre índice de circularidade e magnitude de corridas de detritos em quatro bacias, em Caraguatatuba, São Paulo. O coeficiente de correlação obtido foi 0.

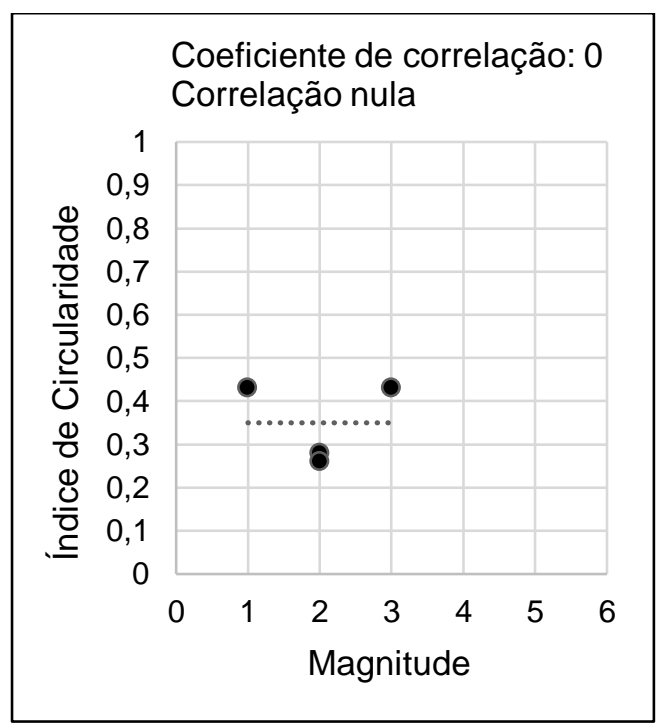

Fonte: modificado de Dias (2017).

Assim como o Ic, o Fator de forma $(F f)$ (Equação 2.10) também trata da feição da bacia, sendo composto pela largura, comprimento e área da bacia. Chen; Yu (2011) utilizaram o parâmetro para avaliação de áreas atingidas por corridas de detritos em bacias hidrográficas de Taiwan, e não encontraram alterações e relação entre o parâmetro e a ocorrência de corridas de detritos.

Equação 2.10: Fator de forma

$$
F f=W / L o=A / L o^{2}
$$

Na qual:

Lo: comprimento do rio (m);

$W$ : média da largura da bacia (m);

$A$ : área da bacia $\left(\mathrm{m}^{2}\right)$. 


\subsection{Classificação de magnitude e hierarquização de bacias hidrográficas a partir de parâmetros morfométricos}

A partir da análise morfométrica de bacias e sua relação com as corridas de detritos, é possível obter um panorama geral das características mais críticas para a ocorrência do processo; da mesma forma, a classificação da magnitude das bacias torna mais evidentes determinados parâmetros. A magnitude de uma corrida de detritos é determinada pelo volume transportado, podendo ser definida como o volume total mobilizado a partir da iniciação até a área de deposição durante um evento. O volume de uma corrida de detritos pode ser estimado a partir de uma aproximação entre a vazão de pico $\left(\mathrm{m}^{3} / \mathrm{s}\right)$, a distância total percorrida, e a distância até o depósito (HUNGR; MCDOUGALL; BOVIS, 2005).

Diversos autores propuseram aproximações empíricas entre vazão de pico $\left(\mathrm{m}^{3}\right)$ e o volume $\left(\mathrm{m}^{3}\right)$, sobretudo para facilitar a estimativa do volume proveniente de uma corrida de detritos visando medidas de mitigação e contenção estrutural (Equação 2.11 e Figura 2.21) (RICKENMANN, 1999). Tal aproximação parte do princípio de que quanto maior a vazão de pico de uma corrida de detritos, maior o seu volume.

Equação 2.11: Relação empírica entre vazão de pico e volume de corridas de detritos.

$$
Q=0.1 V^{5 / 6}=0.1 V^{0.833}
$$

Na qual:

$Q$ : vazão de pico $\left(\mathrm{m}^{3} / \mathrm{s}\right)$;

$V$ : Volume $\left(\mathrm{m}^{3}\right)$;

Figura 2.21: Relação entre Q x V de corridas de detritos.

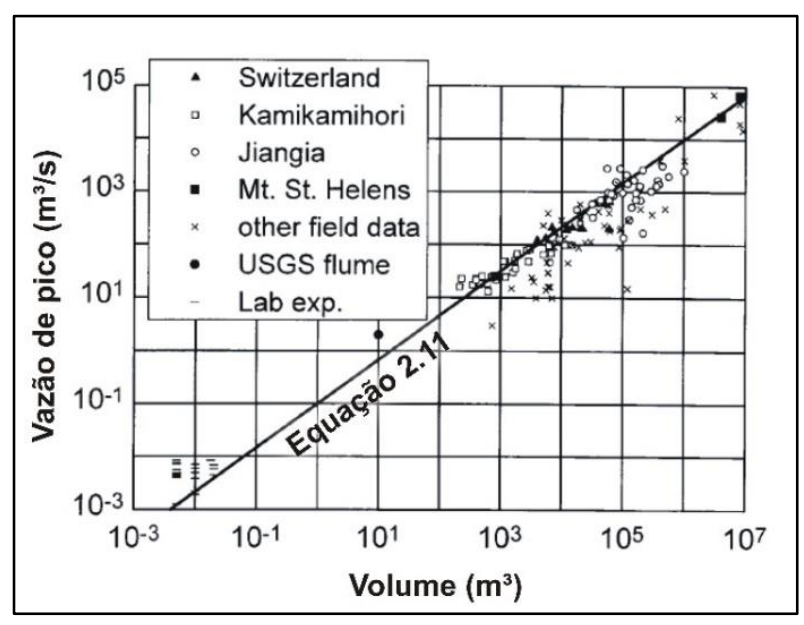

Fonte: modificado de Rickenmann (1999). 
A classificação da magnitude de um evento, por sua vez, pode levar em consideração diversos fatores, desde o atingimento/alcance do evento, até as características dos materiais transportados pelo processo. Com foco nas ocorrências do hemisfério norte, em especial, do Canadá, Jakob (2005b) propôs uma classificação da magnitude a partir de três fatores principais: o volume $\left(\mathrm{m}^{3}\right)$, pico de vazão $\left(\mathrm{m}^{3} / \mathrm{s}\right)$ e área inundada $\left(\mathrm{m}^{2}\right)$ (Tabela 2.4; Figura 2.22). No caso o autor buscou uma classificação que considerasse as diferenças inerentes ao processo, sendo o fator "volume" mais aplicado para a classificação da magnitude de corridas de detritos do tipo "lahars" (vulcânicas), podendo ir até o nível 10 de magnitude; os fatores pico de vazão e área inundada seriam específicos para corridas de detritos com blocos, ou seja, nãovulcânicas, podendo chegar até o nível 6 de magnitude.

Tabela 2.4: Metodologia de classificação de magnitude de corridas de detritos proposta por Jakob (2005b).

\begin{tabular}{|c|c|c|c|c|}
\hline \multicolumn{5}{|c|}{ CLASSIFICAÇÃO DE MAGNITUDE DE CORRIDAS DE DETRITOS } \\
\hline Nível & $\begin{array}{l}\text { Volume } \\
\qquad\left(\mathbf{m}^{3}\right)\end{array}$ & $\begin{array}{c}\text { Pico de } \\
\text { Vazão }\left(\mathbf{m}^{3} / \mathbf{s}\right) \\
\quad *\end{array}$ & $\begin{array}{l}\text { Área inundada } \\
\qquad\left(\mathbf{m}^{2}\right) *\end{array}$ & Consequências Potenciais \\
\hline 1 & $<10^{2}$ & $<5$ & $<4 \times 10^{2}$ & Dano muito localizado em pequenas construções. \\
\hline 2 & $10^{2}-10^{3}$ & $5-30$ & $4 \times 10^{2}-2 \times 10^{3}$ & $\begin{array}{l}\text { Pode enterrar/arrastar carros, destruir pequenas } \\
\text { construções de madeira, derrubar árvores, bloquear } \\
\text { dutos e descarrilar trens. }\end{array}$ \\
\hline 3 & $10^{3}-10^{4}$ & $30-200$ & $2 \times 10^{3}-9 \times 10^{3}$ & $\begin{array}{l}\text { Pode destruir grandes construções, destruir pontes de } \\
\text { concreto, bloquear ou danificar estradas e dutos. }\end{array}$ \\
\hline 4 & $10^{4}-10^{5}$ & $200-1.500$ & $9 \times 10^{3}-4 \times 10^{4}$ & $\begin{array}{l}\text { Pode destruir partes de um vilarejo, destruir parte de } \\
\text { infraestruturas, pontes e bloquear canais. }\end{array}$ \\
\hline 5 & $10^{5}-10^{6}$ & $1.500-12.000$ & $4 \times 10^{4}-2 \times 10^{5}$ & $\begin{array}{l}\text { Pode destruir partes de uma cidade, destruir florestas de } \\
2 \mathrm{~km}^{2} \text { de área, bloquear canais e pequenos rios. }\end{array}$ \\
\hline 6 & $10^{6}-10^{7}$ & N/A & $>2 \times 10^{5}$ & $\begin{array}{l}\text { Pode partes de uma cidade, entulhar vales ou depósitos } \\
\text { de mais de } 10 \mathrm{~km}^{2} \text { de tamanho, criar barragens de } \\
\text { materiais em rios (bloqueio). }\end{array}$ \\
\hline 7 & $10^{7}-10^{8}$ & N/A & N/A & $\begin{array}{l}\text { Pode destruir partes de uma cidade, obstruir vales, com } \\
\text { depósitos de mais de } 10 \mathrm{~km}^{2} \text { em tamanho e criar } \\
\text { barragens de materiais em rios (bloqueio). }\end{array}$ \\
\hline 8 & $10^{8}-10^{9}$ & N/A & N/A & $\begin{array}{l}\text { Pode destruir cidades e inundar grandes vales, com } \\
\text { depósitos maiores de } 100 \mathrm{~km}^{2} \text { de tamanho, criar } \\
\text { barragens de materiais em rios (bloqueio). }\end{array}$ \\
\hline 9 & $10^{9}-10^{10}$ & N/A & N/A & $\begin{array}{l}\text { Destruição vasta e completa por mais de centenas de } \\
\mathrm{km}^{2} \text {. }\end{array}$ \\
\hline 10 & $>10^{10}$ & N/A & N/A & $\begin{array}{l}\text { Destruição vasta e completa por mais de centenas de } \\
\mathrm{km}^{2} \text {. }\end{array}$ \\
\hline
\end{tabular}

*Dados específicos para corridas de detritos com blocos (não vulcânicas). N/A: sem observação destas magnitudes para corridas de detritos com grandes blocos. Fonte: modificado de Jakob (2005b). 
Figura 2.22: Visualização da magnitude segundo segundo fator "volume".

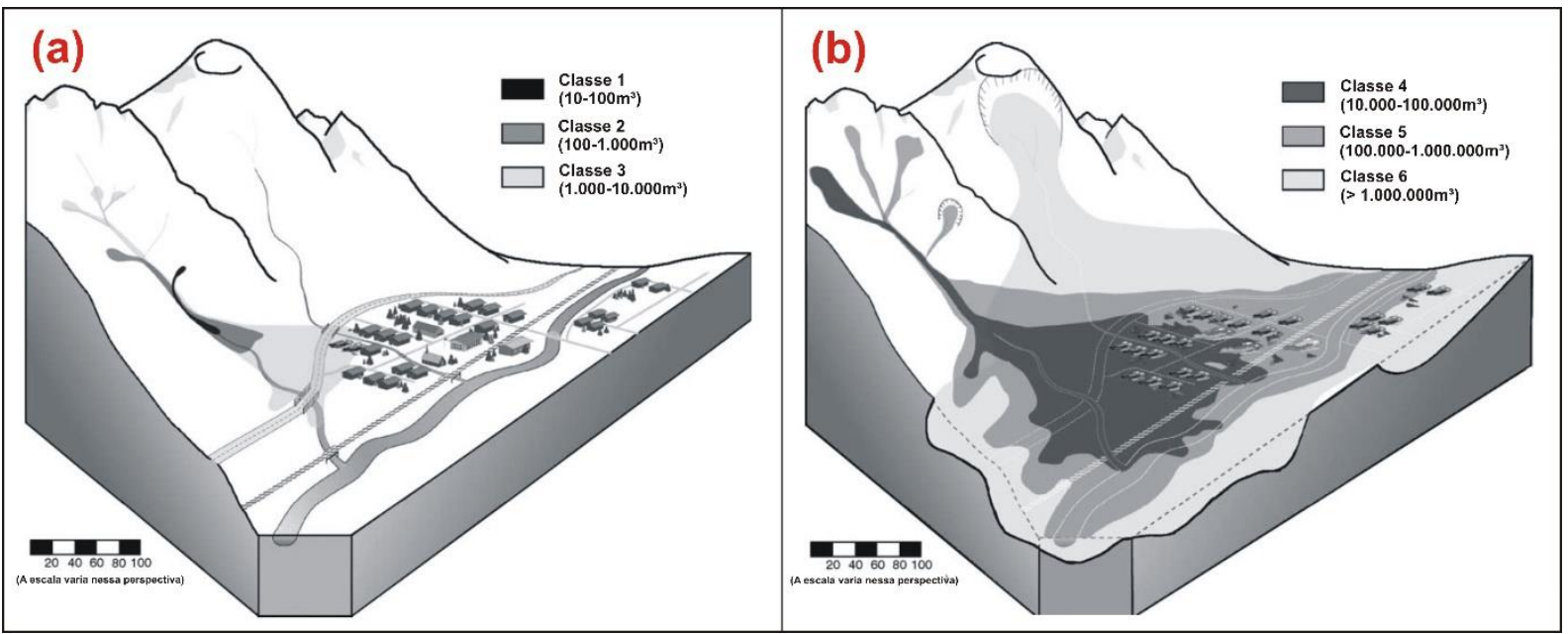

Fonte: modificado de Jakob (2005b).

Outro fator importante a ser levado em consideração ao determinar a magnitude de uma ocorrência são as características morfológicas do fluxo, passiveis de observação em seus depósitos. Quando composto por frações granulométricas mais finas, abrangendo uma grande área, a corrida de detritos tende a possuir um potencial destrutivo menor quando comparada à fluxos com presença de grandes blocos. Neste caso, entende-se que a magnitude de uma ocorrência não se definiria apenas pelo seu alcance ou volume de material transportado, mas também pelas características destes materiais que compõe o fluxo. Neste sentido, ao definir a magnitude das corridas de detritos do evento de 1967 em Caraguatatuba, Dias (2017) propôs a classificação dos blocos que compõe o fluxo em quatro níveis (pequeno, médio, grande, e muito grande) (Figura 2.23).

Figura 2.23: Classificação dos depósitos em quatro categorias: S, M, L e XL.

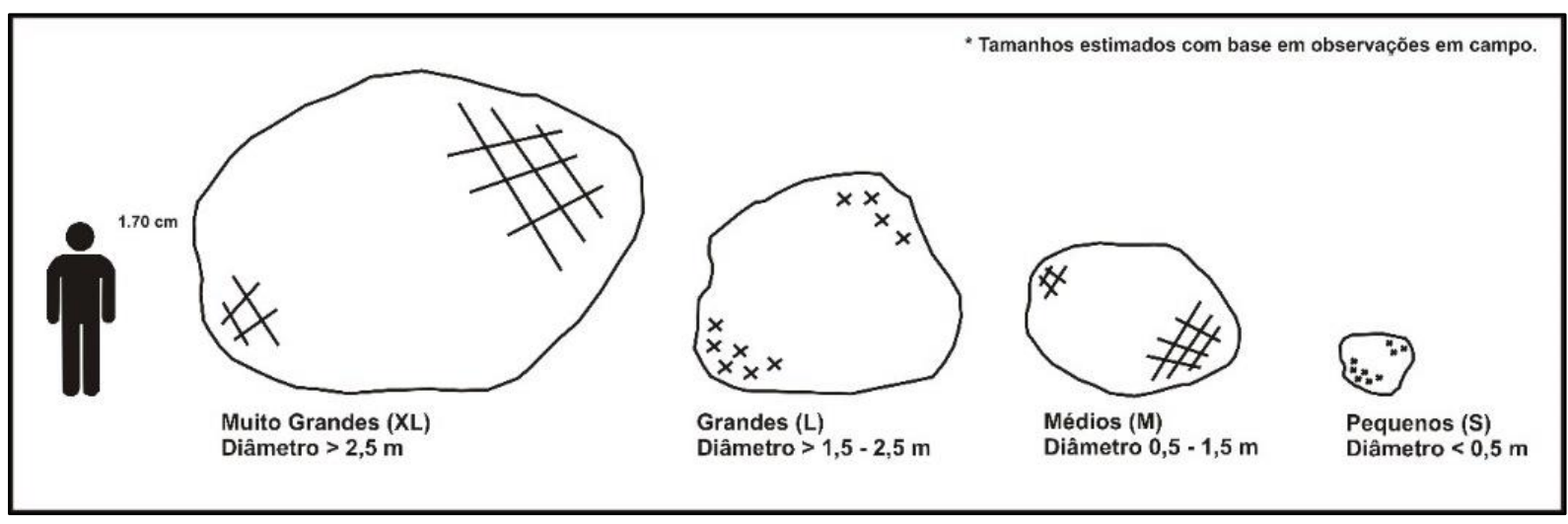

Fonte: Dias (2017). 
Dessa forma, um fluxo composto por blocos de tamanho grande a muito grande possui uma magnitude e possível potencial destrutivo maior do que um fluxo com blocos de tamanho pequeno a médio ou frações granulométricas mais finas. Tais informações contribuem para a caracterização do evento e compreensão de sua dinâmica, sobretudo com relação às características topográficas do relevo, possibilitando o cruzamento de informações.

A combinação das características topográficas/morfométricas e dos eventos pretéritos vem sendo utilizada desde meados dos anos 1980, sobretudo no hemisfério norte, para a classificação, hierarquização e avaliação de probabilidade de novas ocorrências de corridas de detritos. Na região da Columbia Britânica, no Canadá, VanDine (1996) e Slaymaker (1990) utilizaram um manual de classificação de bacias de zero ordem à probabilidade de ocorrências de corridas de detritos. Tal manual leva em consideração fatores como área, ângulo e presença de depósitos de ocorrências pretéritas), podendo classificar a bacia em 4 categorias de probabilidade à ocorrência, indo de muito alta à sem risco (Tabela 2.5).

Tabela 2.5: Categorias de avaliação de probabilidade de ocorrência de corridas de detritos utilizada na Columbia Britânica, Canadá.

\section{CATEGORIA DESCRIÇÃO}

Probabilidade muito alta de ocorrência: indica que corridas de magnitude maior do que a estabelecida pode ocorrer frequentemente em condições de alto escoamento superficial, devendo se assumir a projeção de ocorrência de corridas em curto prazo. É aplicado às bacias que possuem histórico de ocorrência de mais de um evento envolvendo magnitude maior do que $500 \mathrm{~m}^{3}$ de material transportado ou possuindo características físicas compatíveis com bacias com ocorrências de tal magnitude (ex. ângulo $>25^{\circ}$ ).

Probabilidade alta de ocorrência: indica que corridas de magnitude menor vão ocorrer em menor frequência do que na categoria 4 , no entanto, com projeção de ocorrência a curto prazo. É aplicado às bacias com histórico de ocorrência de um único evento. Também é aplicado às bacias sem histórico de ocorrência, porém com características físicas compatíveis às bacias da categoria 4 .

Probabilidade moderadamente alta de ocorrência: indica que a projeção de ocorrência deve ser assumida a ocorrer durante o longo prazo de vida de estruturas físicas (tais como uma ponte ou casa). É aplicado às bacias que possuem características significantes correspondentes aos limites críticos onde a ocorrência de corridas é possível, no entanto, não no intervalo da categoria 4 . Até o presente momento, estas bacias não apresentaram registros históricos de ocorrências, ou de eventos de origem incerta.

Probabilidade baixa de ocorrência: indica potencial baixo de ocorrência de corridas. É aplicado às bacias com características físicas iguais ou semelhantes aos limites críticos onde tais ocorrências são possíveis. Apesar da ocorrência de corrida de detritos seja possível durante o período de vida a longo prazo de estruturas físicas, seria necessária elevada condição de escoamento incomum (e pouco frequente).

Sem risco: indica que não há potencial virtual de ocorrência de corridas de detritos de grande magnitude, porém, pode haver ocorrências locais e de menor magnitude, podendo ocorrer corridas de magnitude variável nos tributários nos cursos superiores. É aplicado às bacias cujas características físicas estão abaixo dos limites críticos onde corridas de detritos são possíveis.

Fonte: Dias (2017), modificado de Thurber Consultants LTD. (1983). 
No Brasil, Kanji e Gramani (2001) propuseram e aplicaram um índice de avaliação de suscetibilidade de bacias às corridas de detritos a partir da ponderação de atributos utilizando parâmetros morfométricos e limiares críticos de chuva. Os autores verificaram a eficácia do índice na determinação da suscetibilidade das bacias ao aplicá-lo para avaliar ocorrências reais de corridas de detritos (Tabelas 2.6 e 2.7).

Tabela 2.6: Fatores, classes, pesos (P), atributos e notas parciais (NP) utilizados para avaliação da suscetibilidade de uma área com relação a corridas de detritos.

\begin{tabular}{|c|c|c|c|c|}
\hline FATORES & CLASSE & $\begin{array}{l}\text { PESO } \\
\text { (P) }\end{array}$ & ATRIBUTOS & $\begin{array}{l}\text { NOTA PARCIAL } \\
\text { (NP) }\end{array}$ \\
\hline \multirow{4}{*}{$\begin{array}{l}\text { Chuva (R) } \\
(\mathrm{mm} / \mathrm{h})\end{array}$} & R1 & \multirow{4}{*}{3} & $>80$ & 10 \\
\hline & $\mathrm{R} 2$ & & $60-80$ & 6,6 \\
\hline & R3 & & $30-60$ & 3,3 \\
\hline & R4 & & $<30$ & 0 \\
\hline \multirow{4}{*}{$\begin{array}{c}\text { Inclinação da Encosta (S) } \\
\left({ }^{\circ}\right)\end{array}$} & S1 & \multirow{4}{*}{2,5} & $>45$ & 10 \\
\hline & S2 & & $45-30$ & 6,6 \\
\hline & S3 & & $15-30$ & 3,3 \\
\hline & S4 & & $<15$ & 0 \\
\hline \multirow{4}{*}{$\begin{array}{l}\text { Declividade do canal (D) } \\
\left(^{\circ}\right)\end{array}$} & D1 & \multirow{4}{*}{0,5} & $>25$ & 10 \\
\hline & D2 & & $15-25$ & 6,6 \\
\hline & D3 & & $10-15$ & 3,3 \\
\hline & D4 & & $<10$ & 0 \\
\hline \multirow{4}{*}{$\begin{array}{c}\text { Área da Bacia (A) } \\
\left(\mathrm{km}^{2}\right)\end{array}$} & A1 & \multirow{4}{*}{1} & $<5$ & 10 \\
\hline & $\mathrm{A} 2$ & & $5-10$ & 6,6 \\
\hline & $\mathrm{A} 3$ & & $10-20$ & 3,3 \\
\hline & A4 & & $>20$ & 0 \\
\hline \multirow{4}{*}{$\begin{array}{c}\text { Altura da Encosta }(\mathrm{H}) \\
(\mathrm{m})\end{array}$} & $\mathrm{H} 1$ & \multirow{4}{*}{1} & $>750$ & 10 \\
\hline & $\mathrm{H} 2$ & & $500-750$ & 6,6 \\
\hline & $\mathrm{H} 3$ & & $200-500$ & 3,3 \\
\hline & $\mathrm{H} 4$ & & $<200$ & 0 \\
\hline \multirow{4}{*}{$\begin{array}{c}\text { Uso e ocupação/vegetação (V) } \\
\text { (\% da área ocupada ou } \\
\text { desmatada) }\end{array}$} & V1 & \multirow{4}{*}{0,5} & $90-100$ & 10 \\
\hline & $\mathrm{V} 2$ & & $50-90$ & 6,6 \\
\hline & V3 & & $30-50$ & 3,3 \\
\hline & V4 & & $<30$ & 0 \\
\hline \multirow{4}{*}{ Aspectos geológicos $(\mathrm{G})$} & G1 & \multirow{4}{*}{1,5} & G1 & 10 \\
\hline & G2 & & $\mathrm{G} 2$ & 6,6 \\
\hline & G3 & & G3 & 3,3 \\
\hline & G4 & & G4 & 0 \\
\hline
\end{tabular}

Fonte: Kanji; Gramani (2001).

Tabela 2.7: Intervalos propostos para determinação de suscetibilidade.

\begin{tabular}{ccc}
\hline Intervalos & & Designações \\
\hline $80-100$ & $\rightarrow$ & Muito alta \\
$60-80$ & $\rightarrow$ & Alta \\
$40-60$ & $\rightarrow$ & Média \\
$20-40$ & $\rightarrow$ & Baixa \\
$0-20$ & $\rightarrow$ & Muito baixa \\
\hline
\end{tabular}

Fonte: Kanji; Gramani (2001). 
Como uma forma simplificada de estabelecer a suscetibilidade de áreas afetadas por corridas de detritos, Gramani et al. (2005) propuseram uma abordagem qualitativa baseada em fatores críticos para a deflagração do processo, ponderados com base em sua importância para o desencadeamento do processo e determinação de suscetibilidade de determinada área (Tabela 2.8).

Tabela 2.8: Índices adimensionais e respectivos pesos.

\begin{tabular}{cc}
\hline FATORES & PESO \\
\hline$\%$ Área total declividade $>30^{\circ}$ & 2,5 \\
\hline Inverso da área total & 0,5 \\
\hline Amplitude da bacia & 1 \\
\hline Declividade da drenagem principal & 0,5 \\
\hline Inverso da circularidade & 0,5
\end{tabular}

Fonte: modificado de Gramani et al. (2005)

Utilizando o tamanho dos blocos como indicador de ocorrência e os Índices adimensionais propostos por Gramani et al. (2005), Gomes (2016) hierarquizou 10 bacias hidrográficas afetadas por corridas de detritos oriundas do evento de 1967, em Caraguatatuba, São Paulo (Tabela 2.9). A autora, no entanto, não verificou uma boa relação entre as bacias hierarquizadas como de maior magnitude e os parâmetros morfométricos.

Tabela 2.9: Classificação de magnitude de bacias afetadas por corridas de detritos em Caraguatatuba, SP.

\begin{tabular}{ccc}
\hline \multirow{2}{*}{$\begin{array}{c}\text { MACIA DE } \\
\text { DRENAGEM }\end{array}$} & $\begin{array}{c}\text { Potencial de geração } \\
\text { de corridas } \\
\text { (GRAMANI et al., } \\
\text { 2005) }\end{array}$ & $\begin{array}{c}\text { Mapeamento dos } \\
\text { depósitos de blocos } \\
\text { (STOFFEL, 2010) }\end{array}$ \\
\hline Aldeia & 7 & MAIOR \\
\hline Canivetal & 5 & MAIOR \\
\hline Guaxinduba & 6 & MAIOR \\
\hline Mococa & 8 & MENOR \\
\hline Santo Antônio & 9 & MAIOR \\
\hline Pau d'alho & 3 & MAIOR \\
\hline Massaguaçu & 2 & MENOR \\
\hline Piraçununga & 10 & MENOR \\
\hline Rio Claro 1 & 1 & MENOR \\
\hline Rio Claro 2 & 4 & MENOR \\
\hline
\end{tabular}

Fonte: modificado de Gomes (2016). 
Da mesma forma, avaliando bacias afetadas por corridas de detritos derivadas do mesmo evento, Dias (2017) utilizou parâmetros morfométricos e classificação da magnitude das ocorrências a partir de resultados em bacias em Caraguatatuba/SP e ponderação de atributos para propor um “Índice de Potencial de Magnitude e Suscetibilidade”. O índice foi proposto e calibrado a partir dos resultados obtidos em bacias específicas e consistiu no cruzamento dos resultados referentes à magnitude das corridas de detritos e parâmetros morfométricos em quatro bacias verificando o coeficiente de correlação entre ambos. Utilizando a proposta de Kanji e Gramani (2001) como base, os parâmetros foram então ponderados com base na sua correlação com a magnitude (pesos maiores foram atribuídos aos parâmetros com maior correlação) gerando uma classificação em 5 níveis, com a possível magnitude e danos a serem causados pelo evento (Tabelas 2.10 e 2.11).

Tabela 2.10: Índice de potencial de magnitude e suscetibilidade.

\begin{tabular}{|c|c|c|c|c|}
\hline PARÂMETRO & PESO & INTERVALO & NOTA & CLASSE \\
\hline \multirow{4}{*}{$\Delta P l$} & \multirow{4}{*}{2,5} & $<150$ & 2,5 & 1 \\
\hline & & $150-200$ & 5 & 2 \\
\hline & & $200-250$ & 7,5 & 3 \\
\hline & & $>250$ & 10 & 4 \\
\hline \multirow{4}{*}{$H d$} & \multirow{4}{*}{2,5} & $<20$ & 2,5 & 1 \\
\hline & & $20-40$ & 5 & 2 \\
\hline & & $40-60$ & 7,5 & 3 \\
\hline & & $>60$ & 10 & 4 \\
\hline \multirow{4}{*}{$A 25$} & \multirow{4}{*}{2} & $<15$ & 2,5 & 1 \\
\hline & & $15-25$ & 5 & 2 \\
\hline & & $25-35$ & 7,5 & 3 \\
\hline & & $>35$ & 10 & 4 \\
\hline \multirow{4}{*}{$R r$} & \multirow{4}{*}{1,5} & $<60$ & 2,5 & 1 \\
\hline & & $60-80$ & 5 & 2 \\
\hline & & $80-100$ & 7,5 & 3 \\
\hline & & $>100$ & 10 & 4 \\
\hline \multirow{4}{*}{$D d$} & \multirow{4}{*}{1} & $<1,5$ & 2,5 & 1 \\
\hline & & $1,5-2,5$ & 5 & 2 \\
\hline & & $2,5-3,5$ & 7,5 & 3 \\
\hline & & $>3,5$ & 10 & 4 \\
\hline \multirow{4}{*}{ Ir } & \multirow{4}{*}{0,5} & $<1.500$ & 2,5 & 1 \\
\hline & & $1.500-2.000$ & 5 & 2 \\
\hline & & $2.000-3.000$ & 7,5 & 3 \\
\hline & & $>3.000$ & 10 & 4 \\
\hline
\end{tabular}

Fonte: modificado de Dias (2017). 
Tabela 2.11: Classificação do índice em 5 níveis.

\begin{tabular}{|c|c|c|}
\hline TOTAL & CLASSIFICAÇÃO & CARACTERÍSTICAS \\
\hline$>90$ & Muito Alto & $\begin{array}{l}\text { Ocorrência de impacto muito alto, podendo destruir partes de uma } \\
\text { cidade, destruir parte de infraestruturas, pontes, bloquear canais, } \\
\text { entulhar vales e criar barragens de materiais nos rios. }\end{array}$ \\
\hline $85-90$ & Alto & $\begin{array}{l}\text { Ocorrência de alto impacto, podendo destruir partes de um vilarejo, } \\
\text { destruir parte de infraestruturas, pontes e bloquear canais e pequenos } \\
\text { rios. }\end{array}$ \\
\hline $65-85$ & Médio & $\begin{array}{l}\text { Ocorrência de médio impacto, podendo destruir grandes } \\
\text { construções, destruir pontes de concreto, bloquear ou danificar } \\
\text { estradas e dutos. }\end{array}$ \\
\hline $45-65$ & Baixo & $\begin{array}{l}\text { Ocorrência de pequeno impacto, podendo causar danos localizados } \\
\text { à pequenas construções. }\end{array}$ \\
\hline$>45$ & Muito Baixo & $\begin{array}{l}\text { Ocorrência de pequeno impacto, provavelmente se restringindo a } \\
\text { modificações no canal de drenagem. }\end{array}$ \\
\hline
\end{tabular}

Fonte: modificado de Dias (2017).

Após esta etapa, a autora classificou as bacias estudadas conforme o índice, verificando possíveis incoerências que poderiam surgir com relação ao resultado da classificação e ao evento real, calibrando o índice por meio destas ocorrências. As quatro bacias estudadas foram classificadas em diferentes níveis, onde as bacias que apresentaram maiores magnitudes obtiveram níveis mais altos (Santo Antônio e Guaxinduba) com relação as bacias com magnitudes menores (Ribeirão da Aldeia e Pau d'alho) (Tabela 2.12).

Tabela 2.12: Classificação das bacias segundo o índice de potencial de magnitude e suscetibilidade.

\begin{tabular}{crrrrr}
\hline $\begin{array}{c}\text { BACIAS / } \\
\text { PARÂMETROS }\end{array}$ & Santo Antônio & Guaxinduba & $\begin{array}{c}\text { Ribeirão da } \\
\text { Aldeia }\end{array}$ & \multicolumn{1}{c}{ Pau d'alho } \\
\hline$\Delta \boldsymbol{P l}$ & 25 & 25 & 6,25 & 10 \\
\hline $\boldsymbol{H} \boldsymbol{d}$ & 25 & 18,75 & 12,5 & 12,5 \\
\hline $\boldsymbol{D} \boldsymbol{d}$ & 10 & 7,5 & 5 & 5 \\
\hline $\boldsymbol{A 2 5}$ & 15 & 15 & 20 & 3,75 \\
\hline $\boldsymbol{I} \boldsymbol{r}$ & 3,75 & 5 & 3,75 & 11,25 \\
\hline $\boldsymbol{R} \boldsymbol{r}$ & 11,25 & & 15 & \\
\hline \multicolumn{1}{l}{ TOTAL } & & 78,75 & 62,5 & 57,5 \\
\hline CLASSIFICAÇÃO & 90 & Médio & Baixo & Baixo \\
\hline
\end{tabular}

Fonte: modificado de Dias (2017). 
Visando estabelecer um modelo base para o desenvolvimento de cartas de suscetibilidade à processos naturais, sobretudo, movimentos de massa, visando sua utilização pelas esferas governamentais em ações de planejamento (BITAR, 2014), a CPRM e o IPT estabeleceram critérios para a delimitação de áreas suscetíveis e seu nivelamento com base na literatura nacional e internacional, determinando os seguintes critérios para bacias suscetíveis à corridas de massa (detritos):

- Unidade de relevo serrano;

- Terrenos com alta suscetibilidade a deslizamentos;

- Amplitude altimétrica > 500 metros;

- Bacias de drenagem com áreas < $10 \mathrm{~km}^{2}$; e

- Índice de Melton, cujo valor deve ser $>0.3$.

Dessa forma, foram estabelecidos três níveis de suscetibilidade para a classificação de bacias hidrográficas, sendo eles alta, média e baixa (Tabela 2.13).

Tabela 2.13: Critérios de classificação de suscetibilidade à movimentos de massa da CPRM.

\begin{tabular}{|c|c|c|c|c|c|}
\hline \multirow[t]{2}{*}{$\begin{array}{c}\text { CLASSE DE } \\
\text { SUCETIBILIDADE }\end{array}$} & \multirow[t]{2}{*}{ CARACTERÍSTICAS PREDOMINANTES } & \multicolumn{2}{|c|}{ ÁREA } & \multicolumn{2}{|c|}{$\begin{array}{c}\text { ÁREA } \\
\text { URBANIZADA } \\
\text { /EDIFICADA }\end{array}$} \\
\hline & & $\mathbf{K m}^{2}$ & $\%$ & $\mathbf{K m}^{2}$ & $\%$ \\
\hline ALTA & $\begin{array}{l}\text { Relevo: serras e morros altos; } \\
\text { Forma das encostas: retílinea e côncava, com } \\
\text { anfiteatros de cabeceiras de drenagem abruptos; } \\
\text { Amplitude: } 50 \text { a } 500 \mathrm{~m} ; \\
\text { - Declividades: }>25^{\circ} ; \\
\text { - Litologia: sedimentos arenosos e conglomerados, } \\
\text { com intercalação de sedimentos síltico-argilosos; } \\
\text { Densidade de lineamentos/estruturas: alta; } \\
\text { - Solos: pouco evoluídos e rasos; e } \\
\text { Processos: deslizamento, corrida de massa, queda } \\
\text { de rocha e rastejo. }\end{array}$ & 94,9 & 37,5 & 0,8 & 7,6 \\
\hline MÉDIA & $\begin{array}{l}\text { - Relevo: morros altos, morros baixos e morrotes; } \\
\text { Forma das encostas: convexas a retilíneas e } \\
\text { côncavas, com anfiteatros de cabeceira de } \\
\text { drenagem; } \\
\text { - Amplitude: } 30 \text { a } 100 \mathrm{~m} ; \\
\text { - Declividade: } 10 \text { a } 30^{\circ} ; \\
\text { Litologia: gnaisses granulíticos ortoderivados } \\
\text { com porções migmáticas; } \\
\text { - Densidade de lineamentos/estrutura: média; } \\
\text { - Solos: evoluídos e moderadamente profundos; e } \\
\text { Processos: deslizamento, queda de rocha e } \\
\text { rastejo. }\end{array}$ & 42,1 & 16,7 & 1,3 & 12,2 \\
\hline
\end{tabular}


- Relevo: planícies e terraços fluviais/marinhos e colinas;

- Forma das encostas: convexas suavizadas e topos amplos;

- Amplitude: < $50 \mathrm{~m}$;

- Declividade: $<15^{\circ}$;

BAIXA - Litologia: cascalho, areia e argila de planícies aluvionares recentes;

- Densidade de lineamentos/estruturas: baixa;

- Solos: aluviais/marinhos; evoluídos e profundos nas colinas; e

- Processos: deslizamento, queda de rocha e rastejo.

Fonte: modificado de Bitar (2014). 


\section{3. ÁREAS DE ESTUDO}

Este capítulo trata da caracterização das áreas de estudo selecionadas para avaliação, partindo de um recorte regional (Serra do Mar) para um recorte local (Itaoca e Serra da Prata). As áreas selecionadas possuem histórico de ocorrência de corridas de detritos recentes $(2011 \mathrm{e}$ 2014), apresentando aspectos físicos e climáticos que favorecem à deflagração do processo, no entanto, as bacias não foram afetadas de forma homogênea pelo processo. Dessa forma, foram selecionadas duas áreas com ocorrência e duas áreas sem ocorrência do processo, a fim de proporcionar uma análise mais objetiva a respeito das possíveis contribuições da morfometria das bacias na deflagração do processo e também realizar uma caracterização detalhada das corridas de detritos.

\subsection{Serra do Mar}

Com extensão de aproximadamente $1.500 \mathrm{~km}$, abrangendo o litoral sul-sudeste do Brasil, nos Estados do Rio de Janeiro, São Paulo, Paraná e norte de Santa Catarina, com picos que chegam a 1.877 m (Pico do Paraná) e 2.000 (Serra dos Órgãos), a Serra do Mar é uma feição geológico-geomorfológica com litologia predominantemente composta por rochas ígneas e metamórficas dos períodos Pré-Cambriano e Eopaleozótico. Sua origem está relacionada à eventos de soerguimento da crosta e erosão da superfície que datam do período Cretáceo (ALMEIDA; CARNEIRO, 1998; IPT, 2002; VIEIRA; GRAMANI, 2015).

Almeida; Carneiro (1998) descrevem a Serra do Mar como um conjunto de escarpas festonadas com orientação predominante seguindo as estruturas do Escudo Atlântico, ou seja, ENE. Segundo os autores, trata-se da feição orográfica mais destacada da borda Atlântica do continente sul-americano. Abarcando o litoral de quatro estados, a Serra do Mar não segue o mesmo padrão ao longo de sua extensão, devido, sobretudo, às diferenças litológicas que propiciam diferenças quanto às taxas erosivas, estando a serra, por exemplo, mais próxima no litoral norte e mais afastada à costa no litoral sul do Estado de São Paulo, o que pode ser observado nos demais estados, onde, em geral, encontra-se mais afastada da costa, originando planícies mais amplas (AB'SABER, 1955, 1956).

A geologia da Serra do Mar é predominantemente composta por rochas de origem ígnea e metamórfica, com destaque para granitos, gnaisses e quartzitos, além da presença de falhas e fraturas, que condicionam as orientações regionais da serra e favorecem zonas de fragilidade à ocorrência de processos morfodinâmicos (AB'SABER, 1956; ALMEIDA; CARNEIRO, 1998). Com relação à Geomorfologia, a feição é composta por um relevo montanhoso, com presença 
de anfiteatros, vales profundos, encostas íngremes e alta densidade de drenagem (IPT, 2002). Segundo a classificação de Koppen (1936), a região possui clima subtropical úmido, com verão quente, sem estação seca (Cfa).

Nos meses correspondentes ao período do verão (dezembro-março), são frequentes elevados volumes pluviométricos, que combinados às características geológicas e geomorfológicas, contribuem para a deflagração de movimentos de massa, mais especificamente, escorregamentos e corridas de detritos (KANJI; CRUZ; MASSAD, 2008; TATIZANA et al., 1987). Muitas ocorrências são, inclusive, deflagradas por acumulados de chuvas que chegam à mais de $500 \mathrm{~mm}$ em pouco mais de 48 horas (Figura 3.1). Destaca-se a ocorrência em Caraguatatuba, em 1967 (586 mm/48h), município localizado na região da Serra do Mar (CRUZ, 1974).

Figura 3.1: Gráfico da relação entre acumulado de chuva $(\mathrm{mm})$ e tempo (horas), estipulando uma curva de limite crítico exponencial (em vermelho) para a determinação do volume de chuva necessário para a deflagração de eventos catastróficos.

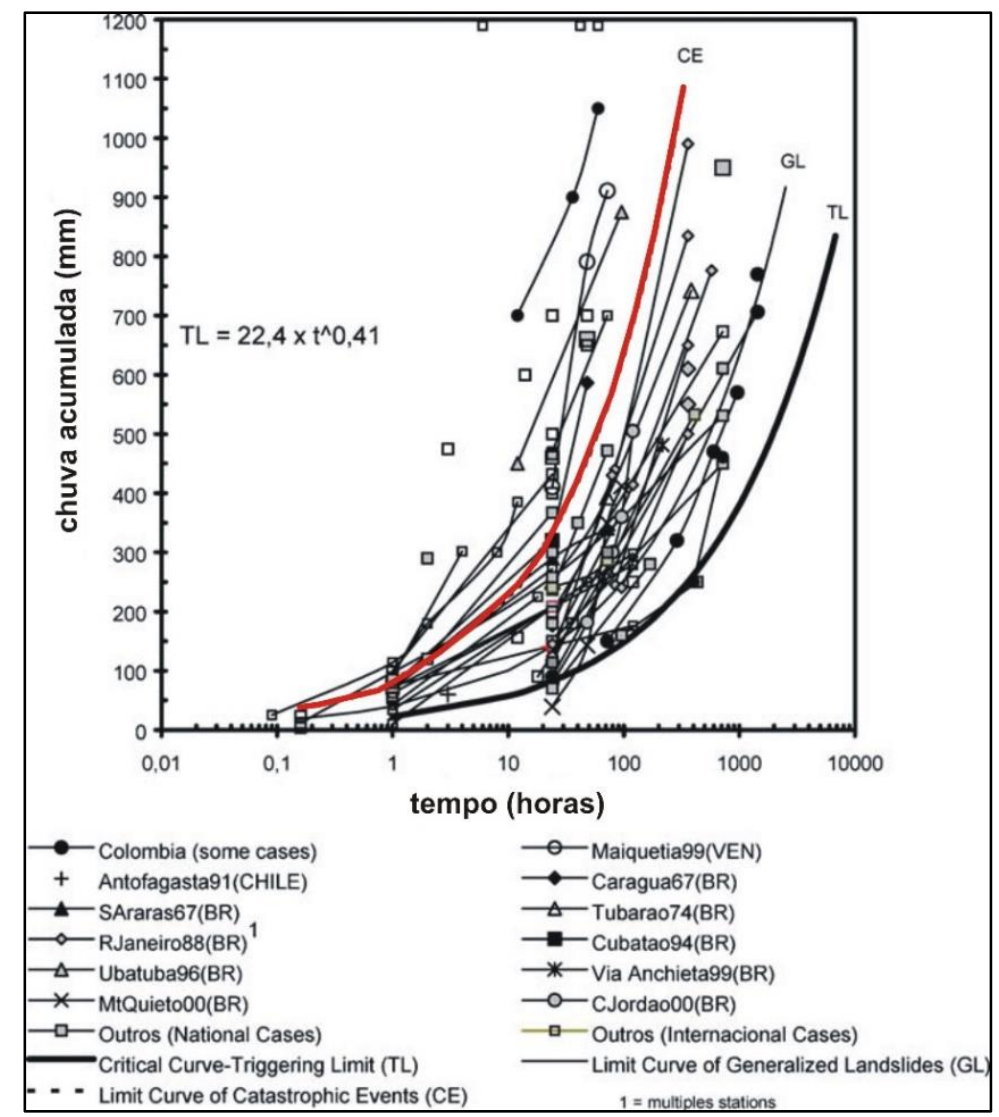

Fonte: adaptado de Kanji; Cruz; Massad (2008). 
A ocorrência de movimentos de massa de proporções catastróficas é recorrente dada a sua suscetibilidade (DIAS et al., 2021a), sobretudo por tratar-se de uma área de interesse econômico, com presença de industrias e rodovias importantes que fazem a ligação entre o interior do país e o Porto de Santos (principal porto do Brasil e maior complexo portuário da América Latina); e também por ser densamente ocupada pela população, tanto em sua porção escarpada (ex. Região Serrana do Rio de Janeiro) quanto nas porções mais planas, geralmente onde estão concentrados os centros urbanos dos municípios.

As áreas de estudo selecionadas na região da Serra do Mar (Figura 3.2) foram Itaoca, no Estado de São Paulo, que se destaca devido à ocorrência recente em 2014; e a região da Serra da Prata, localizada no Estado do Paraná, que, apesar de não ter causado danos severos às infraestruturas e perdas significativas de vida humana foram registradas corridas de detritos com expressiva mobilização de materiais.

Figura 3.2: Localização das áreas de estudo.

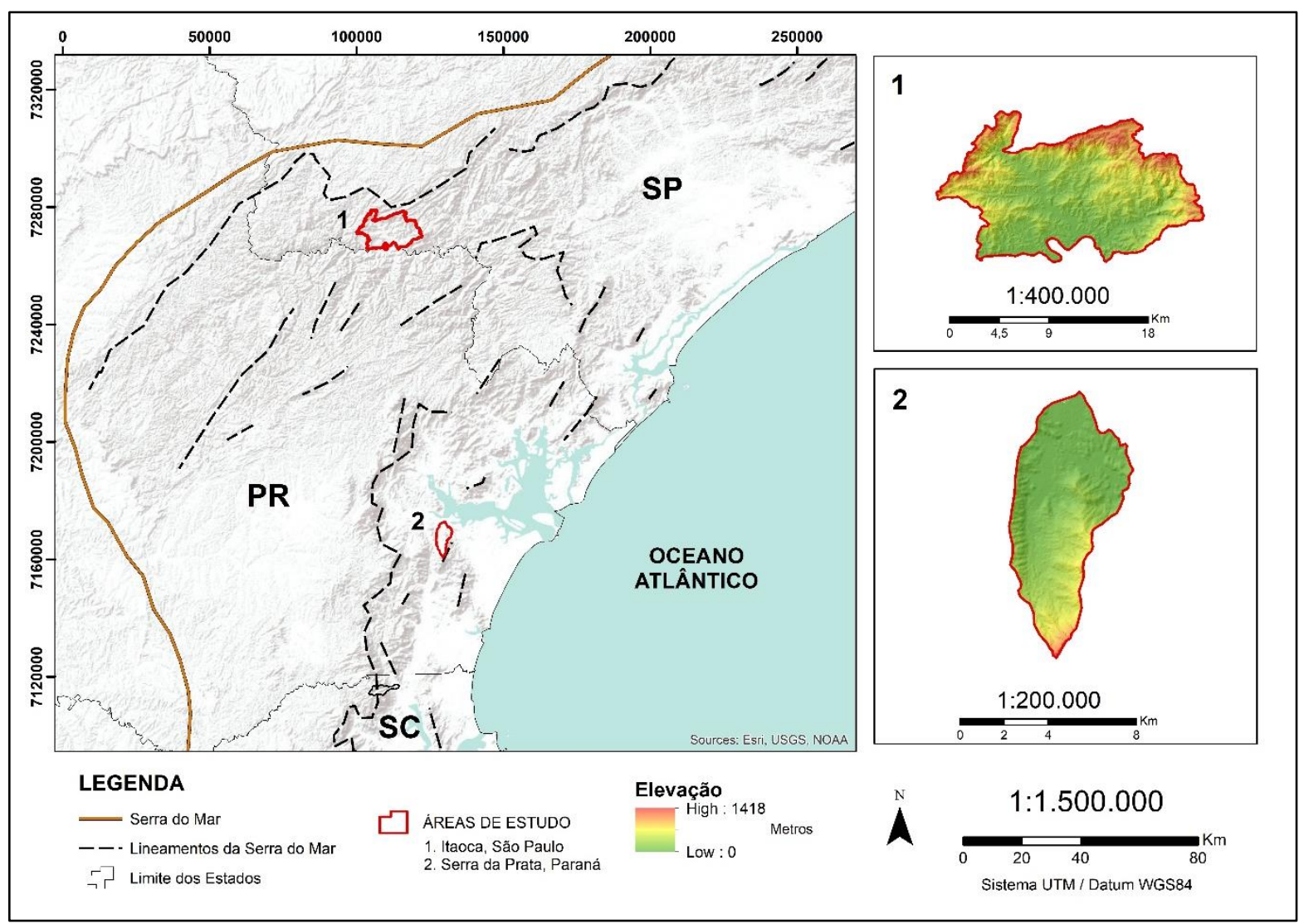




\subsection{Serra da Prata (Bacia do Jacareí), Paraná}

\subsubsection{Caracterização Geral}

A região da Serra da Prata, localizada no Estado do Paraná, abarca diferentes municípios do Estado. No caso deste estudo, dada as ocorrências catastróficas recentes, optou-se pelo recorte contendo os municípios de Morretes e Paranaguá, na região da bacia Jacareí (Figura 3.3), intensamente afetados pelo evento de 2011. O município de Morretes $\left(684,580 \mathrm{~km}^{2}\right)$ 15.718 habitantes e IDHM de 0,686 (médio); já o município de Paranaguá (826,674km²) possui a maior população, 175,078 habitantes e IDHM de 0,750 (médio), segundo dados do último censo de 2010 (IBGE, 2018). A bacia Jacareí possui 38,95 km², elevada amplitude altimétrica (> $1.000 \mathrm{~m}$ ), e drenagem do tipo dendrítica (porções mais baixas do relevo) e paralela (porções mais altas e íngremes), com destaque para o elevado número de afluentes e sub-bacias, características que a tornam propensa a ocorrência de corridas de detritos.

Figura 3.3: Localização da bacia Jacareí, de parte da região denominada Serra da Prata, no Estado do Paraná, abarcando os municípios de Morretes e Paranaguá.

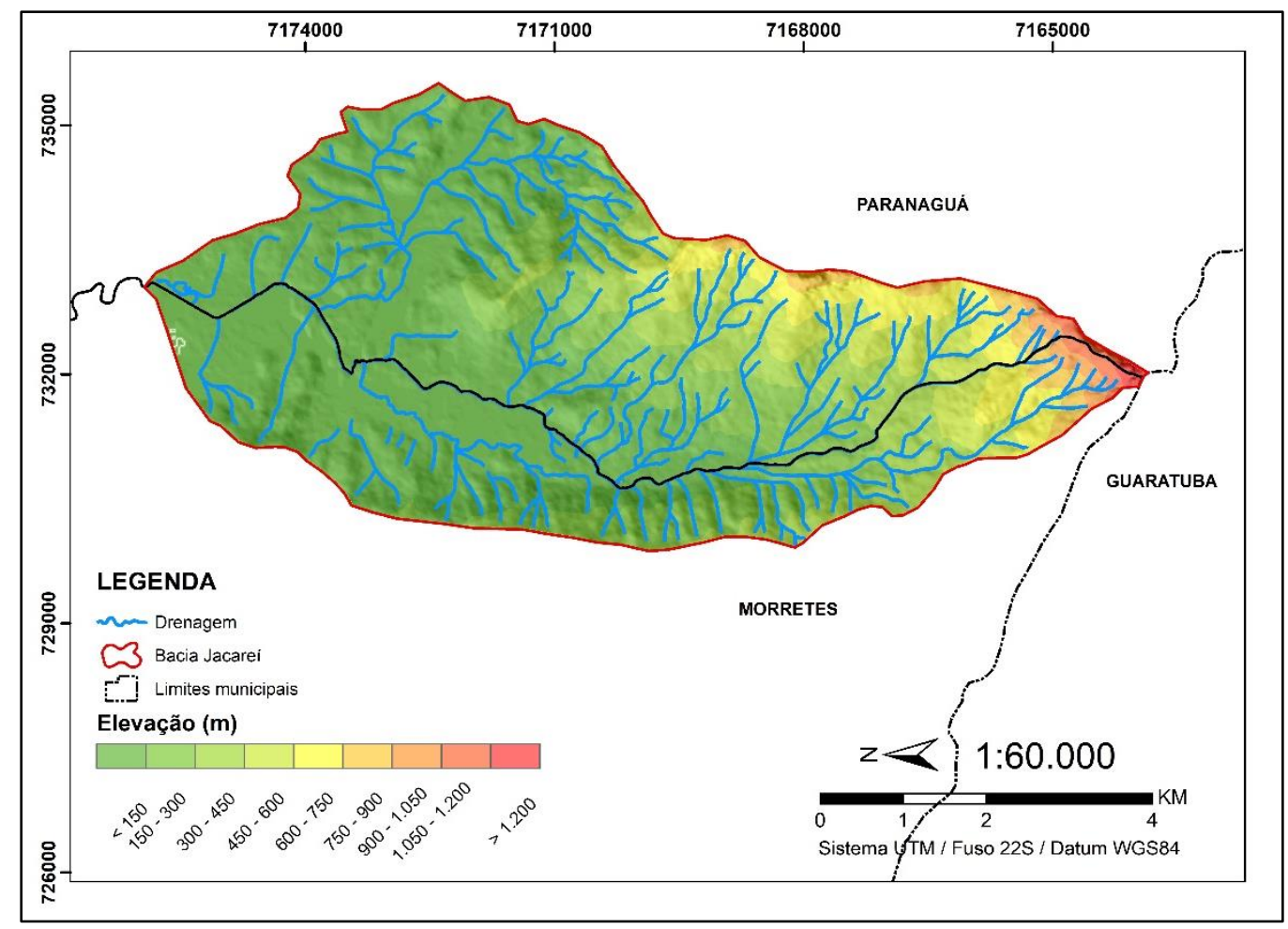

A compartimentação do relevo do Paraná elaborada por Maack (1947) possui divisão em cinco setores, que se distinguem quanto à litologia e geomorfologia, sendo eles: 1) Litoral; 2) Serra do Mar; 3) Primeiro Planalto; 4) Segundo Planalto; e 5) Terceiro Planalto (Figura 3.4). A região estudada encontra-se inserida no contexto do Cinturão Orogênico do Atlântico (Serra 
do Mar), apresentando embasamento pré-cambriano com predomínio de rochas de origem ígneas e metamórficas com idades entre 500 e 600 milhões de anos, tais como granito, gnaisses, xistos, paragnaisses e quartzitos (BIGARELLA et al., 1978; MAACK, 1947).

Figura 3.4: Esquema da estrutura geológica do relevo do Paraná. 1: sedimentos cenozóicos da Planície Costeira e Plataforma Continental; 2: sedimentos cenozóicos da Bacia de Curitiba; 3: Grupos Bauru e Caiuá (Cretáceo); 4: Bacia de Santos; 5: derrames de basalto da Formação Serra Geral; 6: unidades paleozóicas e mesozóicas da Bacia do Paraná; 7: Formação Furnas; 8: embasamento pré-cambriano. Cidades - PAR: Paranaguá; CTB: Curitiba; PGR: Ponta Grossa; GUA: Guarapuava. Escarpas: SM: Serra do Mar; ED: Escarpa Devoniana; SG: Serra Geral.

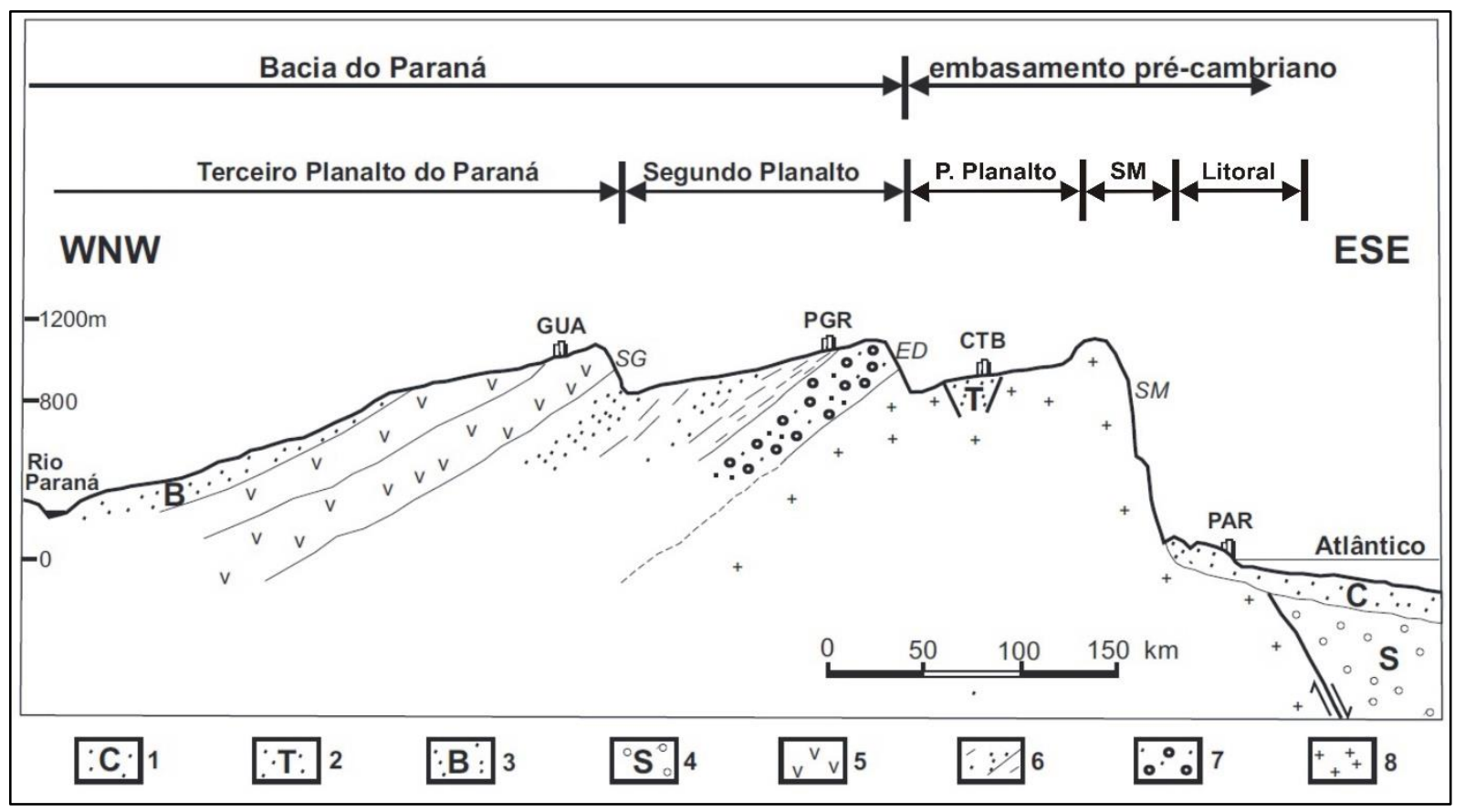

Fonte: Modificado de Melo et al. (2014).

Segundo o Mapa Geológico do ITCG (2006) (Figura 3.5), possuem maior expressão na área o Complexo Gnáissico-Migmático, onde predominam granitos metassomáticos ou de anatexia, indiferenciados, migmatitos estromáticos com paleosoma de biotita-hornblenda gnaisse, mica-quartzo xisto, ultrabasito, metabasito e anfibolito, migmatitos indiferenciados, com anfibolitos e veios quartzo-feldspáticos associados a migmatitos "dent de cheval". 
Figura 3.5: Mapa Geológico da Região da Serra da Prata.

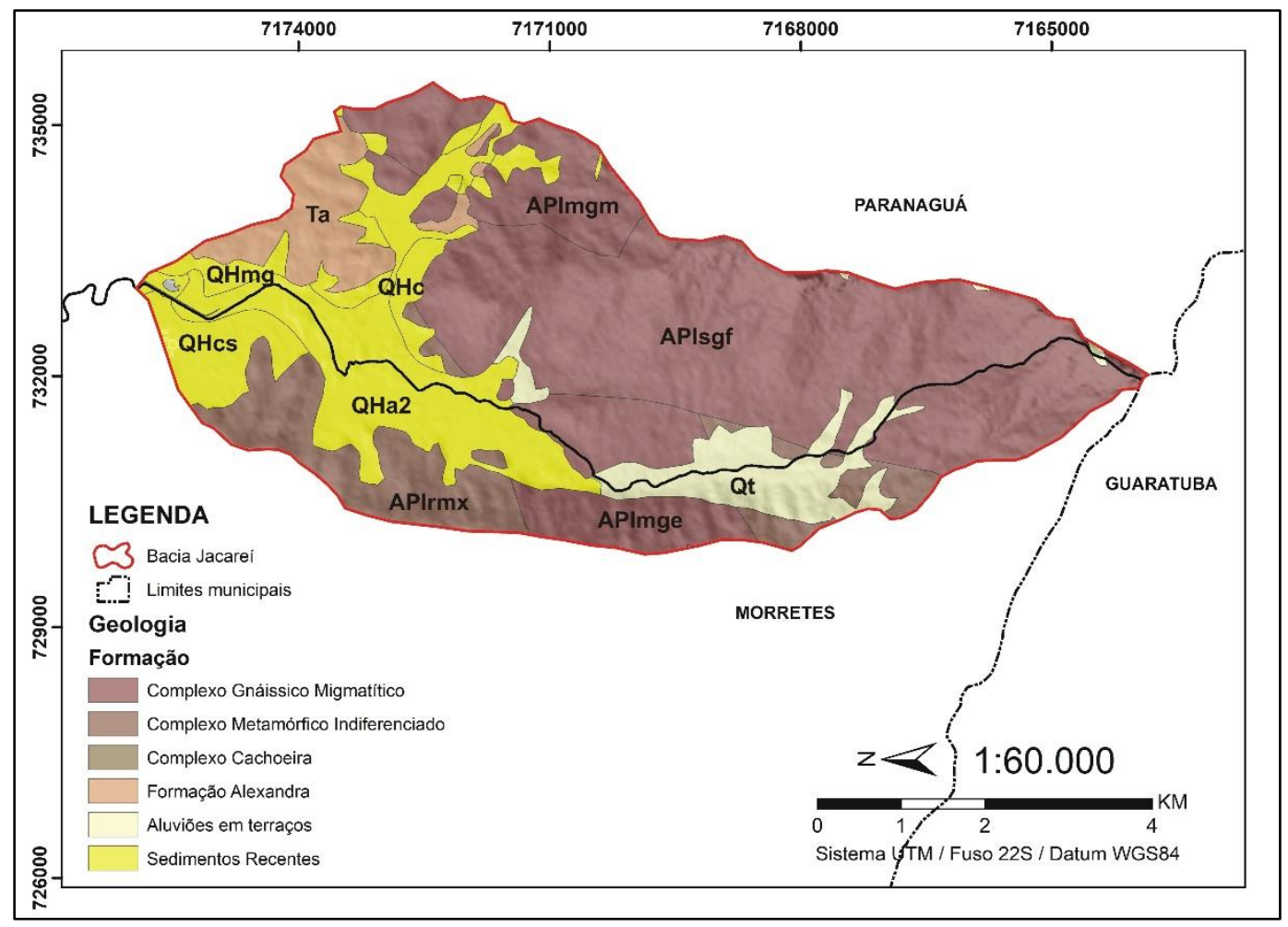

Fonte: ITCG (2006).

Com relação à geomorfologia, denominada localmente "Serra da Prata", esta região da Serra do Mar Paranaense representa um degrau entre o planalto interior e o litoral, assim como uma serra marginal bem delimitada com elevações entre 500 e $1.000 \mathrm{~m}$ sobre o nível geral do Primeiro Planalto (MAACK, 1947). De acordo com o Mapa geomorfológico elaborado por Oka-Fiori et al. (2006), predominam na área Escarpas e Morros da Serra do Mar e Morros Baixos e Litorâneos (Figura 3.6).

Segundo a classificação de Koppen (1936), o clima na região é Cfa nas altitudes até $700 \mathrm{~m}$ e $\mathrm{Cfb}$ nas altitudes acima de $700 \mathrm{~m}$. As temperaturas variam entre $-3{ }^{\circ} \mathrm{C}$ nos meses mais frios, e mais de $22^{\circ} \mathrm{C}$ nos meses mais quentes (BLUM, 2006; BLUM; RODERJAN; GALVÃO, 2011). As precipitações médias mensais variam entre 333,70 mm (janeiro) a $91 \mathrm{~mm}$ (agosto), segundo média mensal entre os anos de 1970 e 2000. Se destacam os meses de janeiro, fevereiro e março como os mais chuvosos (Figura 3.7). 
Figura 3.6: Mapa Geomorfológico da Região da Serra da Prata.

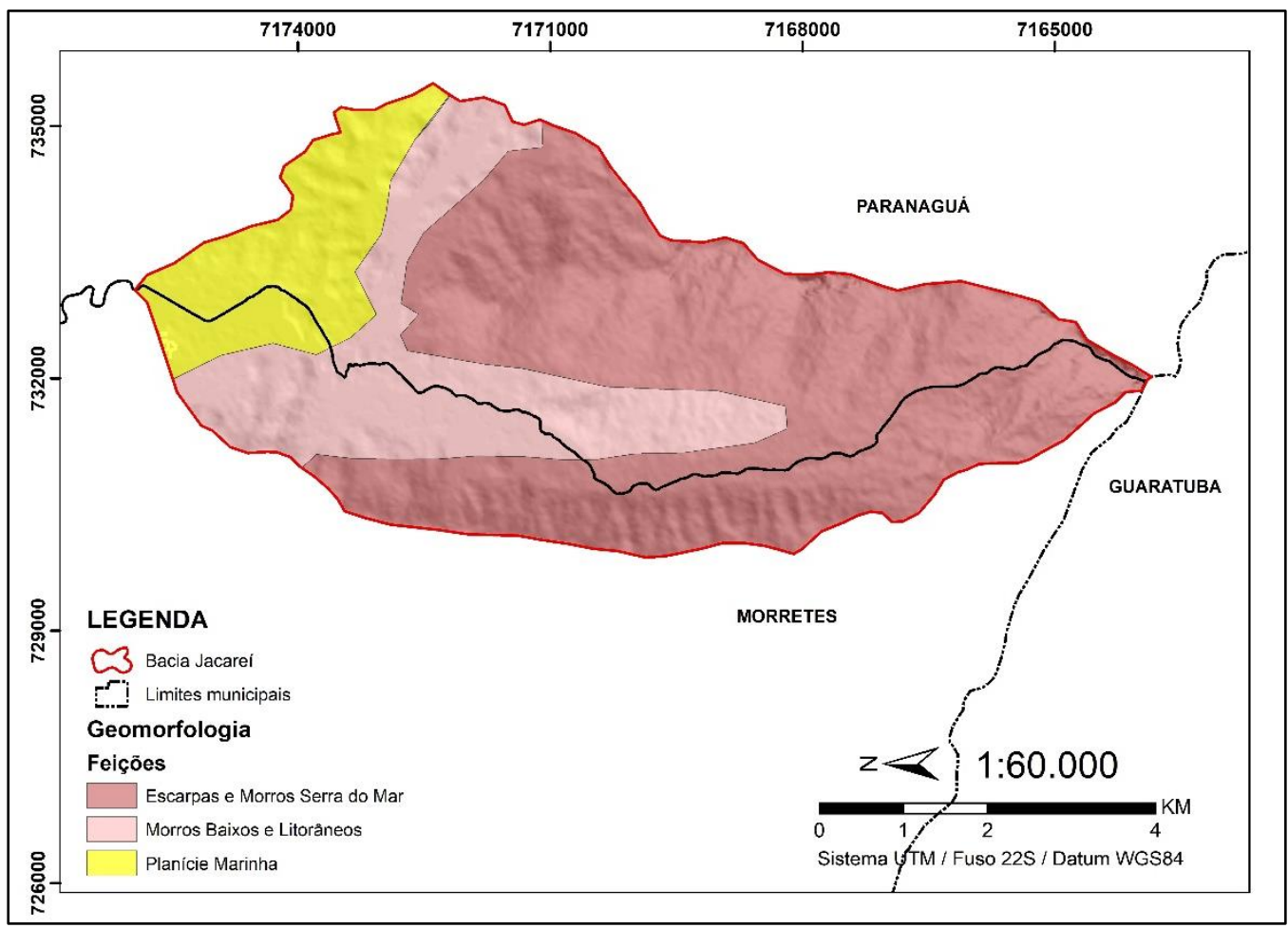

Fonte: Oka-Fiori et al. (2006).

Figura 3.7: Precipitações Médias Mensais na região da Serra da Prata durante o período de 1970-2000. Destaque para os meses de dezembro, janeiro e fevereiro, com os maiores valores.

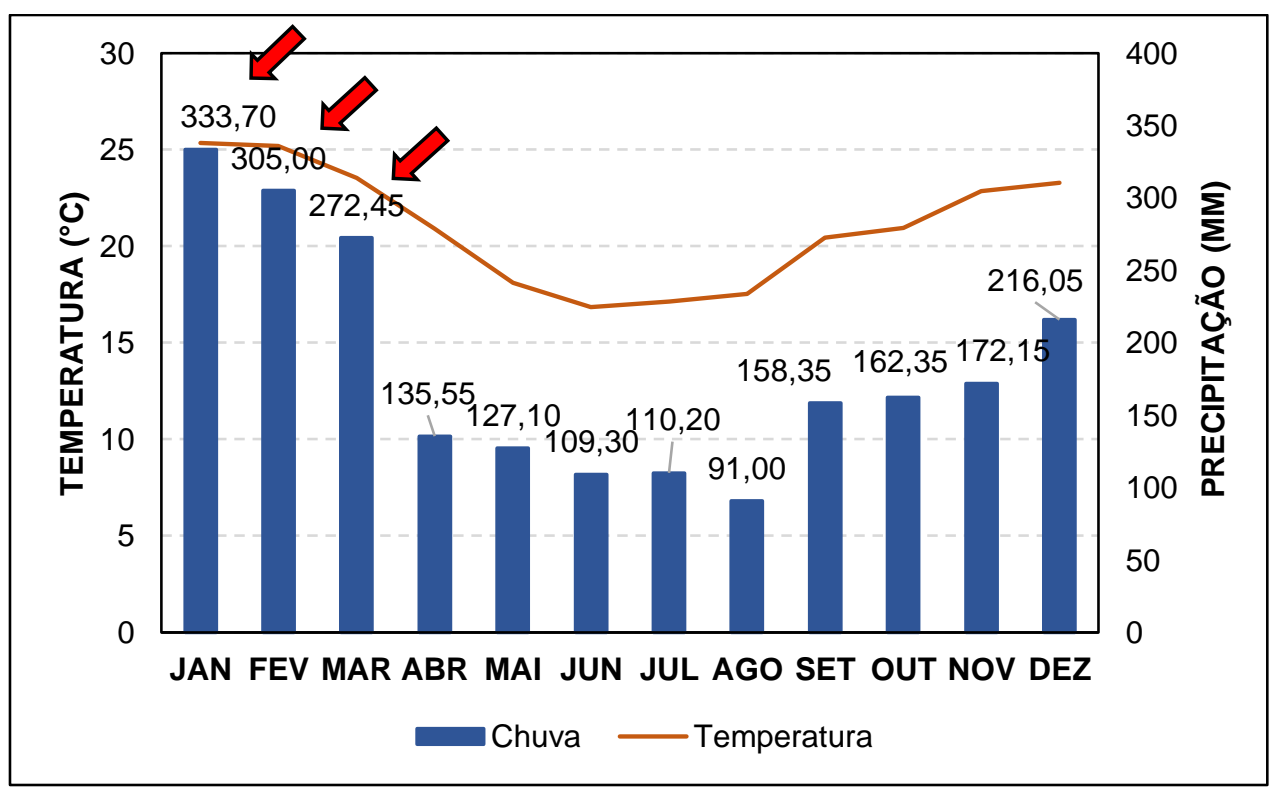

Fonte: Águas Paraná (2018).

As formações fitogeográficas que se destacam na região são a Floresta Ombrófila Densa Submontana, Montana e Altomontana (ITCG, 2009), classificadas de acordo com as variações 
altimétricas do relevo. Com relação à cobertura pedológica da região dos municípios, segundo o ITCG (2008), o Cambissolo é a tipologia mais frequente, com ocorrências de Latossolos nas áreas mais baixas do relevo e Afloramentos de Rochas em cotas mais elevadas; Segundo Picanço et al. (2016), com um enfoque mais voltado para a Serra da Prata, nas encostas mais íngremes predominam os Neossolos, nas encostas menos íngremes predominam saprolitos rasos e solos coluvionares, ocorrendo depósitos de talus na base das encostas. 


\subsubsection{Evento de 2011}

No verão de 2011, mais especificamente em 11 de março, elevados volumes pluviométricos deflagraram escorregamentos e corridas de detritos na região (ZAI et al., 2017). O evento na Serra da Prata chama a atenção devido ao volume de materiais mobilizados pelas corridas de detritos e pelas características dos depósitos. Apesar das grandes dimensões da bacia, observa-se que as corridas alcançaram as porções mais planas do relevo, entulhando e destruindo ponte em rodovia sobre o Rio Jacareí (Figura 3.8).

Figura 3.8: Processo de corridas de detritos na bacia Jacareí. Depósito à jusante, compostos majoritariamente por material lenhoso, causando danos à rodovia (a). Depósito à montante, composto por grandes blocos. Destaque para a localização dos depósitos na bacia (b).

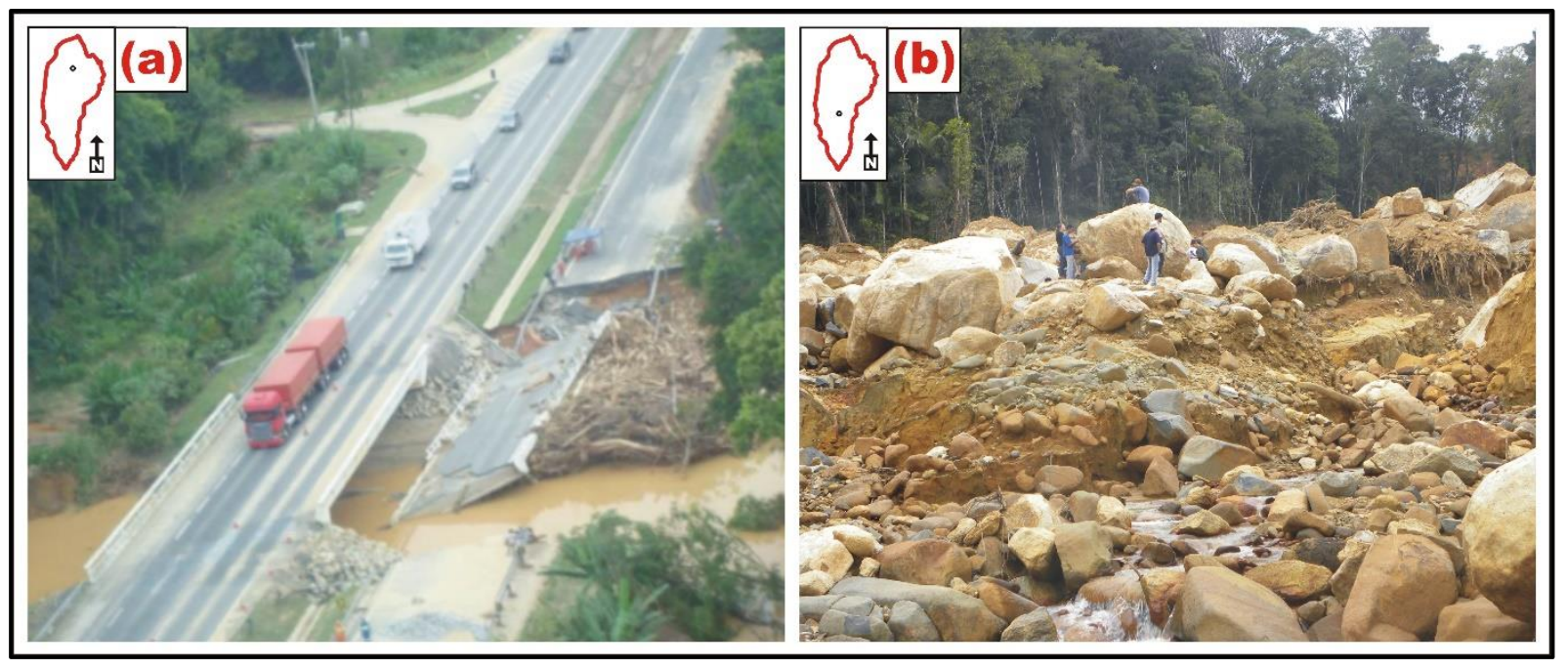

Fonte: Zai et al. (2017) (a); GPmorfo (b).

Segundo Picanço et al. (2016), a maior parte das corridas de detritos ocorreram nas subbacias do Jacareí, onde foram identificados depósitos compostos por blocos com mais de $10 \mathrm{~m}$ que entulharam o leito de rios, causando grande modificação na paisagem local. Os autores destacam que apesar de não ter atingido áreas densamente urbanizadas, os processos promoveram uma intensa modificação na paisagem local, destacando o vale do rio Tingidor, afluente do rio Jacareí, como uma das áreas mais atingidas.

As corridas de detritos foram deflagradas a partir do aporte de materiais (solos, blocos, matéria orgânica) provinda de escorregamentos deflagrados nas encostas (Figura 3.9), e promoveram o aumento significativo da largura do rio em decorrência do transporte do elevado volume de detritos. Seguindo a dinâmica do processo, ocorreu primeiramente a deposição dos materiais mais grosseiros, composto por grandes blocos gigantes (Figura 3.10). 
Figura 3.9: Escorregamentos deflagrados nas encostas da bacia Jacareí, na Serra da Prata, Paraná.

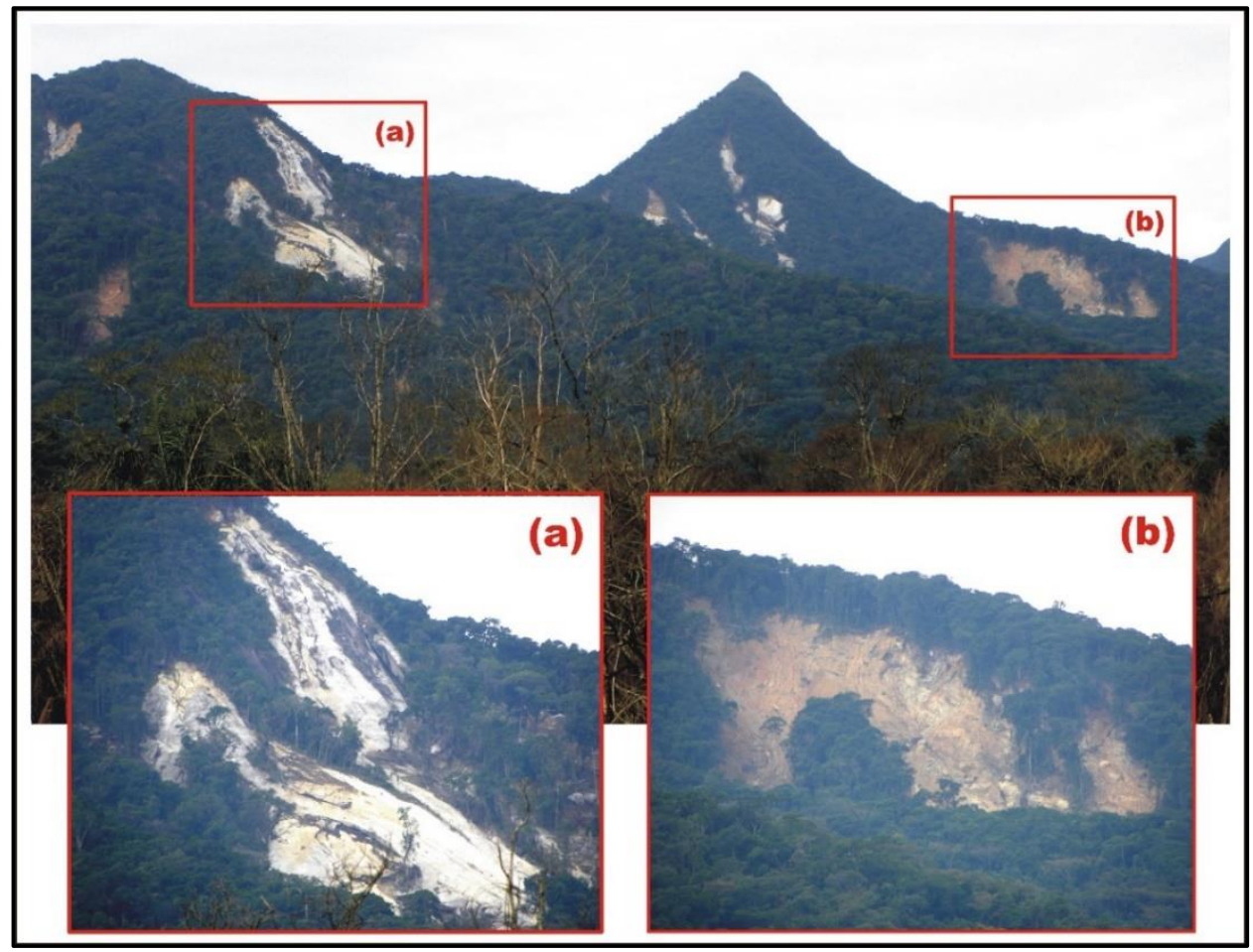

Fonte: GPmorfo.

Figura 3.10: Depósito de corrida de detritos com blocos gigantes, na bacia do rio Tingidor.

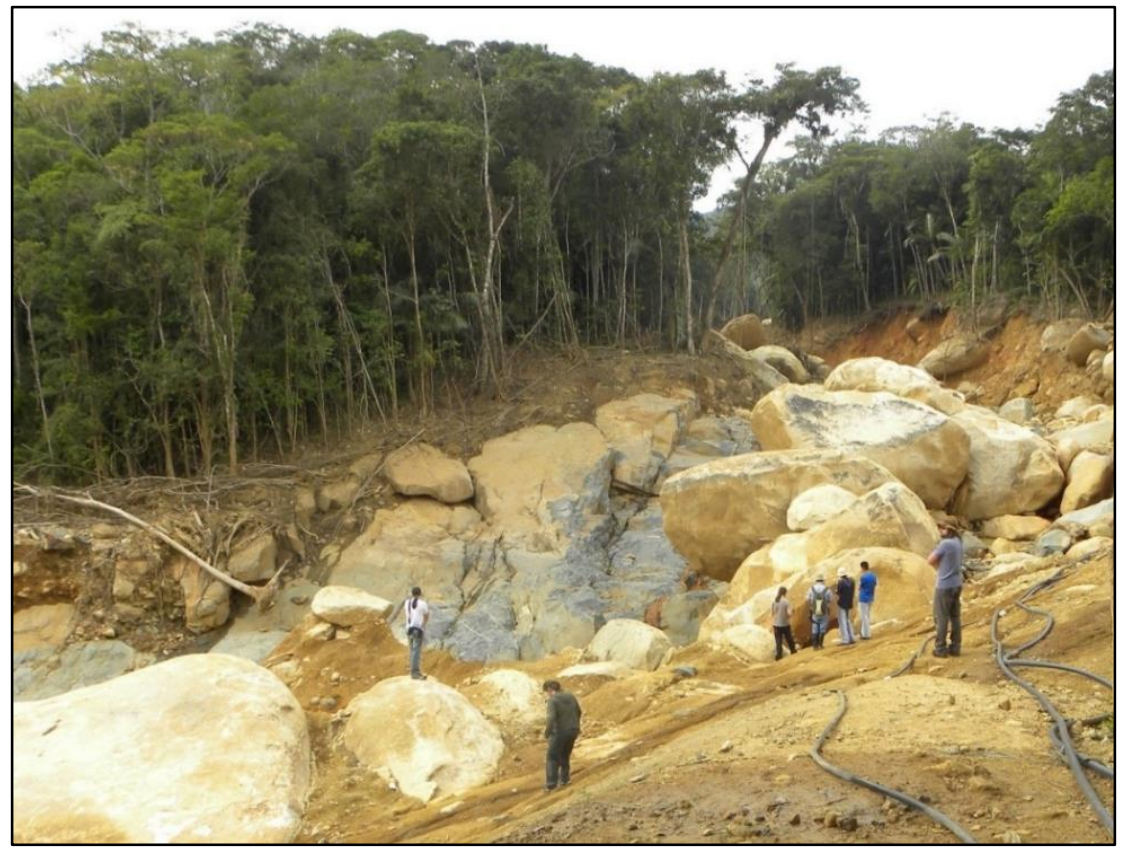

Fonte: GPmorfo. 
Nas porções mais baixas do relevo, predomínio a deposição de materiais mais finos, e, sobretudo, grande quantidade de troncos e material lenhoso, que causaram danos às moradias localizadas na área e à rodovia (Figuras 3.11 e 3.12).

Figura 3.11: Deposição de materiais mais finos (a) e blocos menores (b), na planície da bacia.

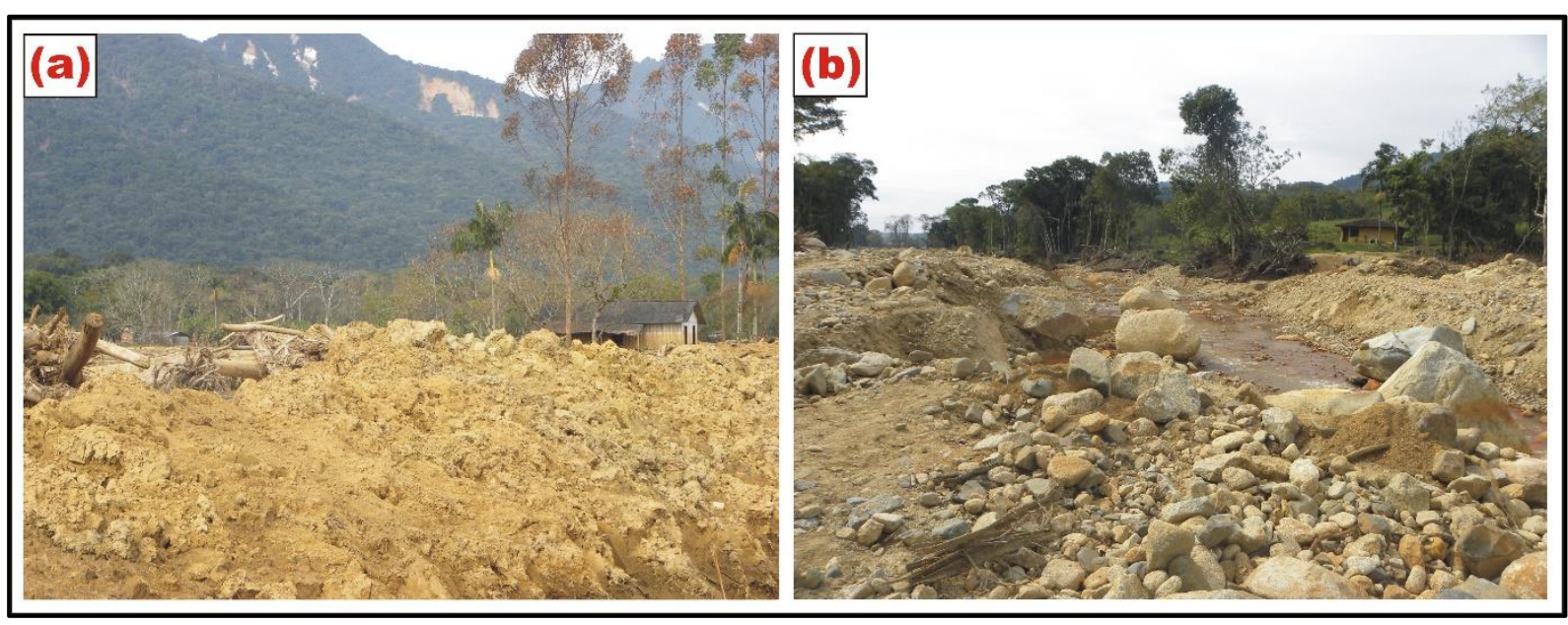

Fonte: GPmorfo.

Figura 3.12: Moradia atingida pelas corridas de detritos, com deposição de materiais finos e lenhosos (a); ponte sobre o rio Jacareí parcialmente destruída em Rodovia que liga Curitiba ao litoral (b).

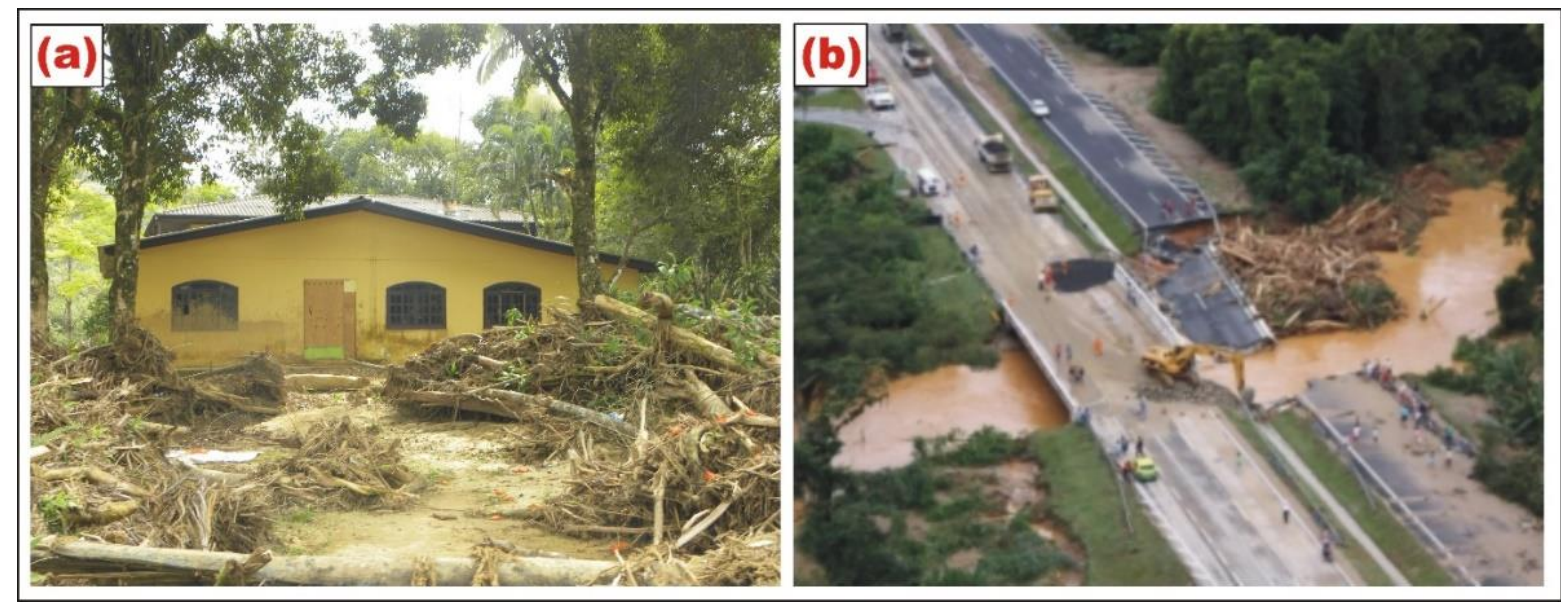

Fonte: GPmorfo. 


\subsubsection{Bacia do rio Tingidor}

Localizada na região da Serra da Prata, a sub-bacia Tingidor é um dos afluentes da bacia Jacareí (Figura 3.13). Possui 2,02 $\mathrm{km}^{2}$ de área e hierarquia de drenagem de $3^{\circ}$ ordem, segundo a metodologia de Strahler $(1952,1957)$. Em 2011, elevado volume pluviométrico contribuiu para a deflagração de corridas de detritos, com elevado volume de sedimentos e materiais diversos (ex. trocos, blocos), que causaram danos às moradias e a rodovia de acesso ao litoral do Estado do Paraná. A bacia foi uma das mais atingidas pelo processo de corridas de detritos, causando danos às propriedades e intensa modificação na paisagem devido à intensa erosão e elevado volume de materiais transportados.

Figura 3.13: Bacia Tingidor, sub-bacia da Jacareí, localizada na região da Serra da Prata, Paraná.

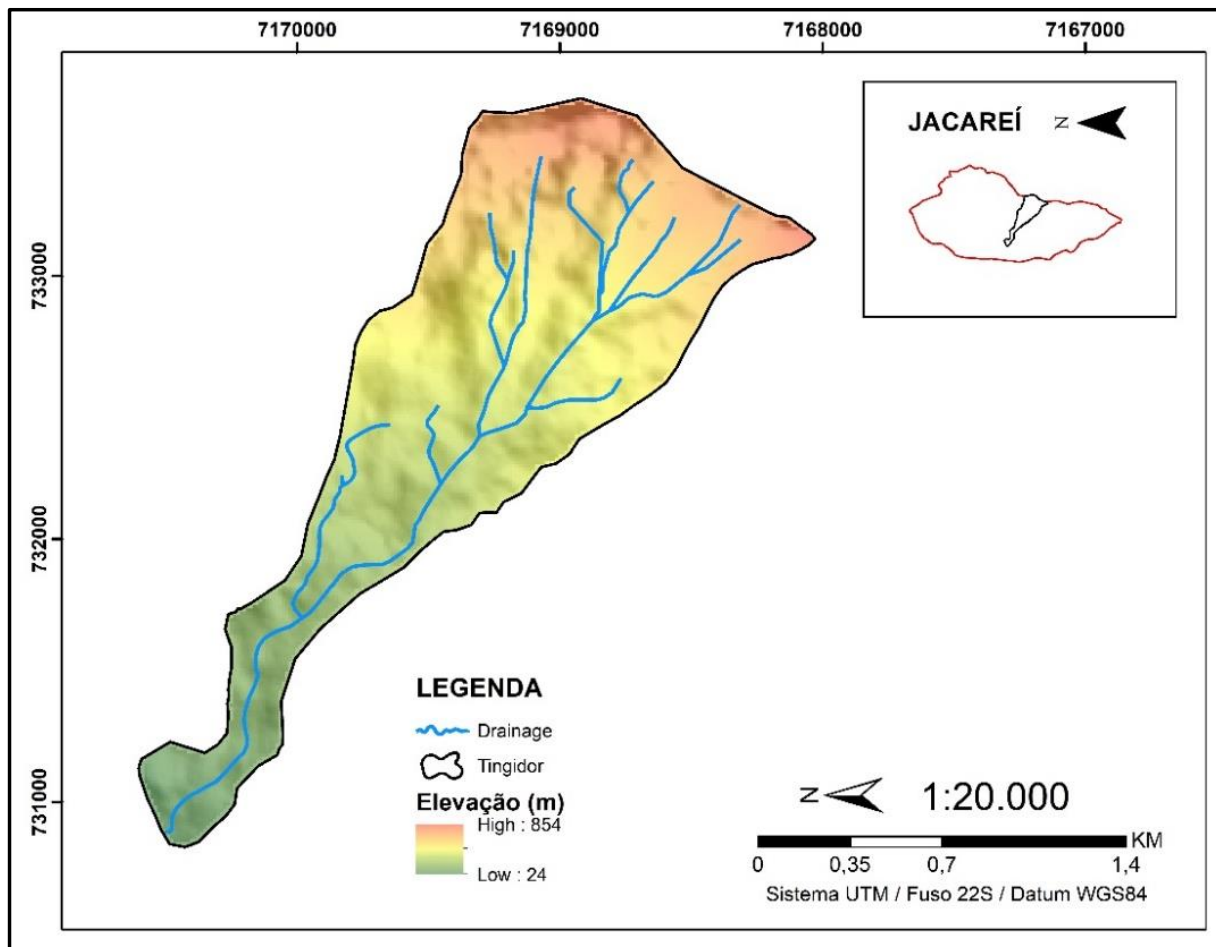

As corridas de detritos foram deflagradas a partir aporte de materiais oriundos dos escorregamentos, atingindo as drenagens já saturadas pela chuva e dando início ao processo de transporte e mobilização de materiais diversos, que chegaram até as porções mais baixas do relevo, inclusive ao rio principal da bacia Jacareí, atingindo a rodovia de acesso ao litoral (Figura 3.14). 
Figura 3.14: Escorregamentos nas encostas (a) que deflagraram as corridas de detritos (b) na bacia Tingidor.

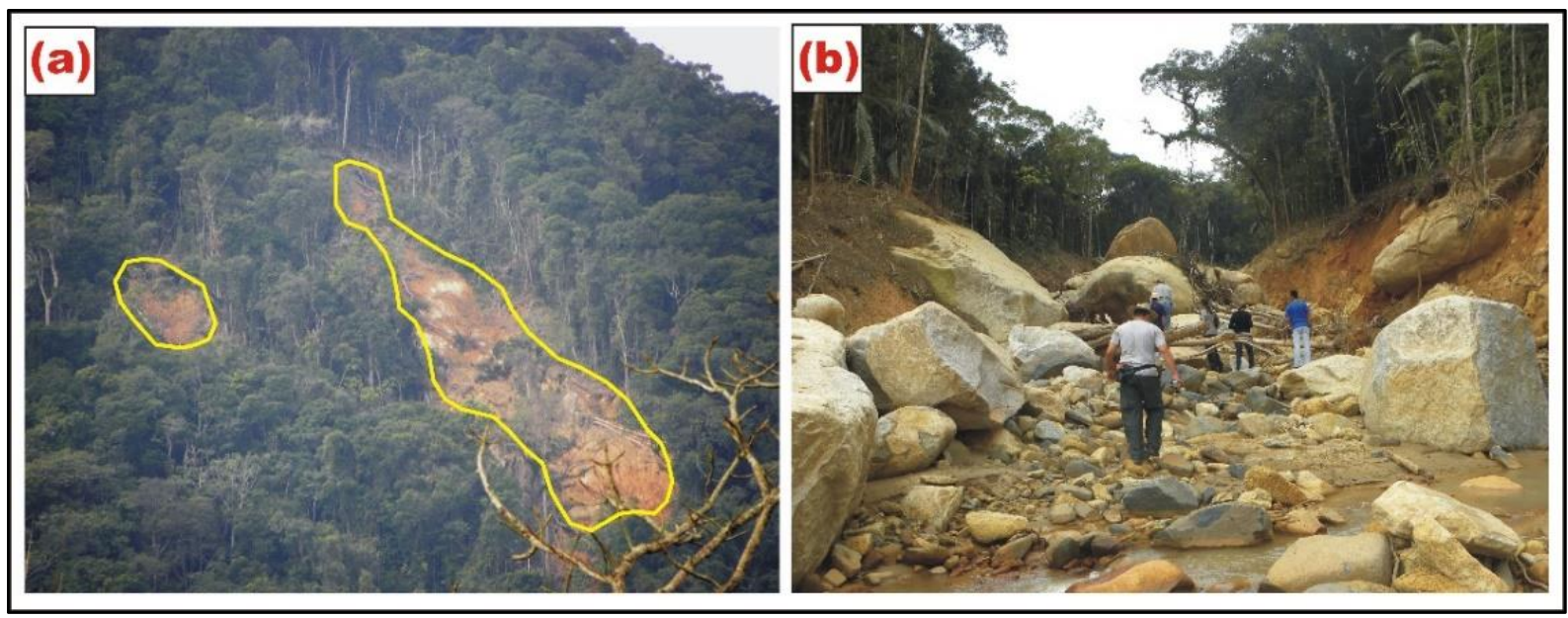

Fonte: GPmorfo.

Martins et al. (2012) fizeram uma descrição dos processos de corridas de detritos ocorridos e caracterizaram a área atingida em 4 setores (Tabela 3.1), que podem ser definidos como área fonte de matéria (setor 1), deposição inicial e erosão (setor 2), deposição secundária (setor 3) e deposição final (4). O primeiro setor caracteriza-se por ser a área de iniciação do processo, ou área fonte, sendo composta neste caso pela cicatriz dos escorregamentos, que forneceram material para deflagração das corridas de detritos em alta encosta. $\mathrm{O}$ segundo setor é composto pelos depósitos iniciais da corrida, caracterizando-se pela presença de blocos de tamanho denominado "gigante" e intensa erosão do vale. Já o terceiro setor apresenta a deposição ainda composta por blocos, no entanto, estes possuem menor tamanho que aqueles depositados no setor anterior. Por fim, o quarto setor apresenta depósitos compostos por materiais de granulometria fina e predomínio de matéria orgânica (Figura 3.15).

Tabela 3.1: Caracterização das corridas de detritos na sub-bacia do Rio Tingidor, Região da Serra da Prata.

\begin{tabular}{cl}
\hline SETOR & \multicolumn{1}{c}{ CARACTERÍSTICAS } \\
\hline 1 & Cicatrizes dos escorregamentos. \\
\hline 2 & $\begin{array}{l}\text { Corte e entulhamento do vale, com depósitos compostos por materiais } \\
\text { mais grosseiros: blocos de tamanho "gigante" }(10-30 \mathrm{~m}) .\end{array}$ \\
\hline 3 & $\begin{array}{l}\text { Depósito de blocos em leque, que modificaram totalmente a paisagem } \\
\text { local. }\end{array}$ \\
\hline 4 & $\begin{array}{l}\text { Depósito de menor densidade, composto predominantemente por } \\
\text { matéria orgânica (troncos) e sedimentos mais finos. }\end{array}$ \\
\hline
\end{tabular}

Fonte: Copilado a partir de Martins et al. (2012). 
Figura 3.15: Característica das corridas de detritos na bacia Tingidor, segundo setorização de Martins et al. (2012). Setor 1 (a), iniciação do processo; Setor 2 (b), deposição inicial com blocos gigantes; Setor 3 (c), deposição dos blocos menores em leque; e Setor 4 (d), deposição final com sedimentos finos e matéria orgânica.

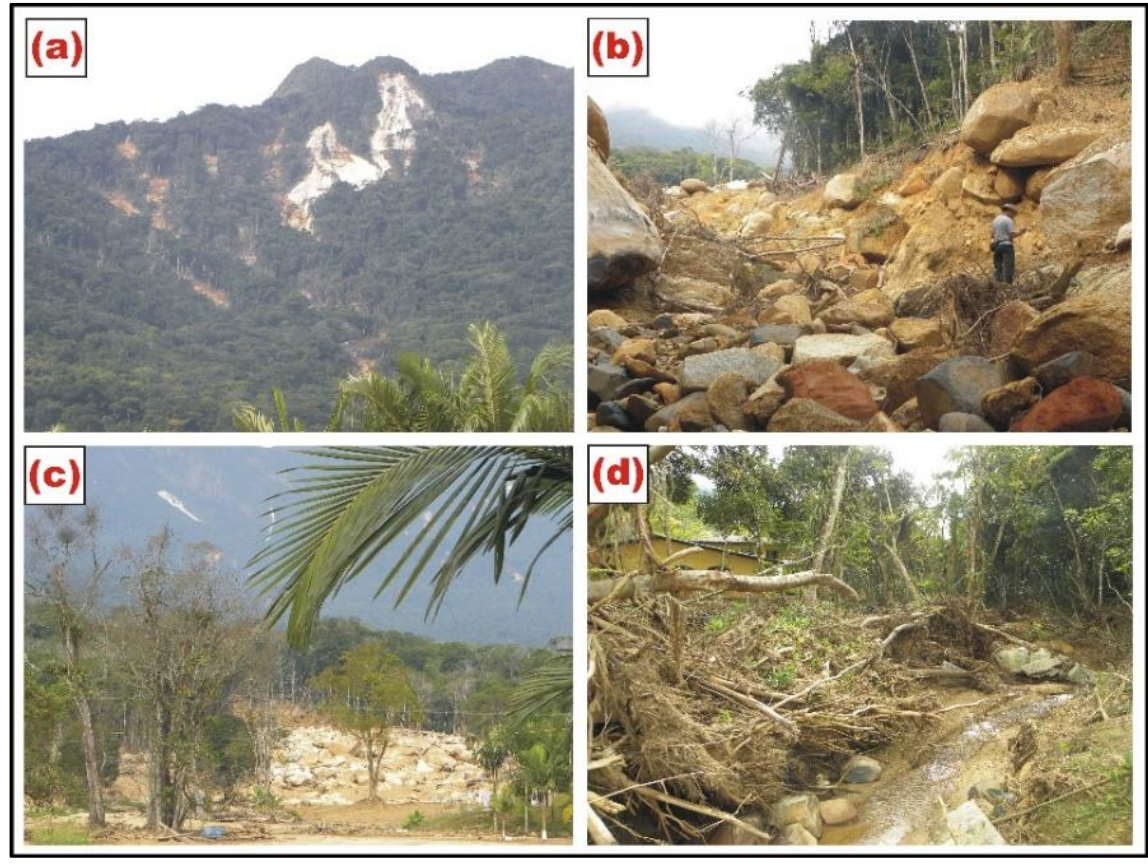

Fonte: GPmorfo. 


\subsection{Itaoca, São Paulo}

\subsubsection{Caracterização geral}

O município de Itaoca está localizado no sul do Estado de São Paulo São Paulo, na divisa com o Paraná (Figura 3.16), com uma área de $183 \mathrm{~km}$. Segundo o último censo do IBGE de 2010, possui 3.228 habitantes, com IDHM de 0,680, considerado médio (IBGE, 2018).

Do ponto de vista geológico, Itaoca está inserida no contexto do Cinturão Ribeira, "sendo constituida, dominantemente, por rochas pré-cambrianas, com menor ocorrência de rochas intrusivas mesozoicas e unidades sedimentares fanerozoicas" (FALEIROS; MORAIS; VICENTE, p. 21, 2012). O Maciço Itaoca (Figura 3.17), composto por rochas graníticas, que ocupa quase a totalidade da área do município (aproximadamente 80\%), se destaca dentre aos demais subgrupos aos quais encontra-se circundado. Segundo o Mapa Geológico da CPRM (Figura 3.18), as unidades Granito Itaoca (Suítes Itaoca e Saltinho) são compostas pelas rochas Granito, Monzogranito, Quartzo-Monzonito, Quartzo-Sienito e Biotita. Já a formação Serra da Boa Vista apresenta rochas predominantemente metamórficas, Filito, Metarenito, Metassiltito e Metarenito Conglomerático (PERROTTA et al., 2005).

Figura 3.16: Mapa de Localização do Município de Itaoca/SP.

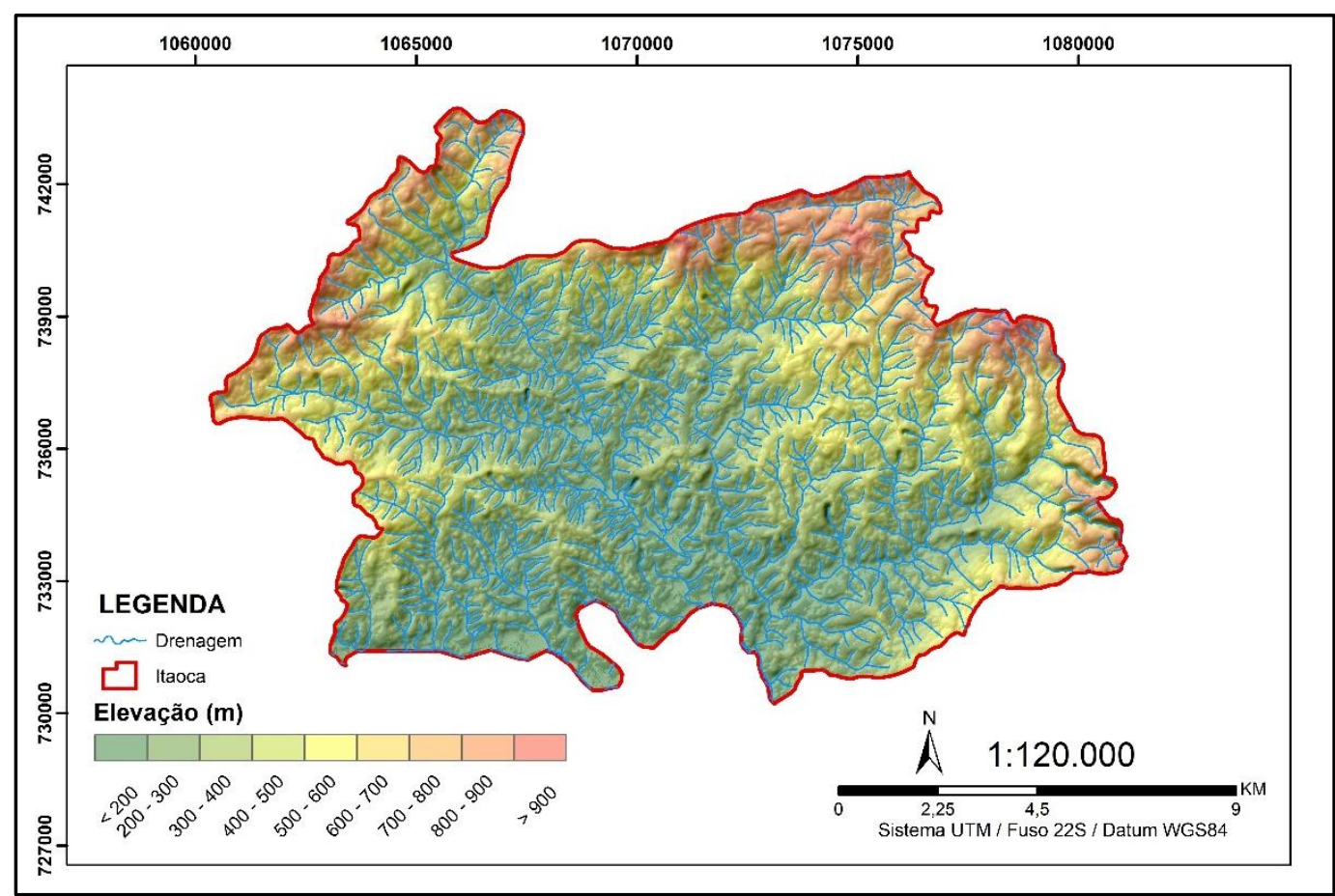


Figura 3.17: Geologia simplificado dos encaixes do Maciço Itaoca.

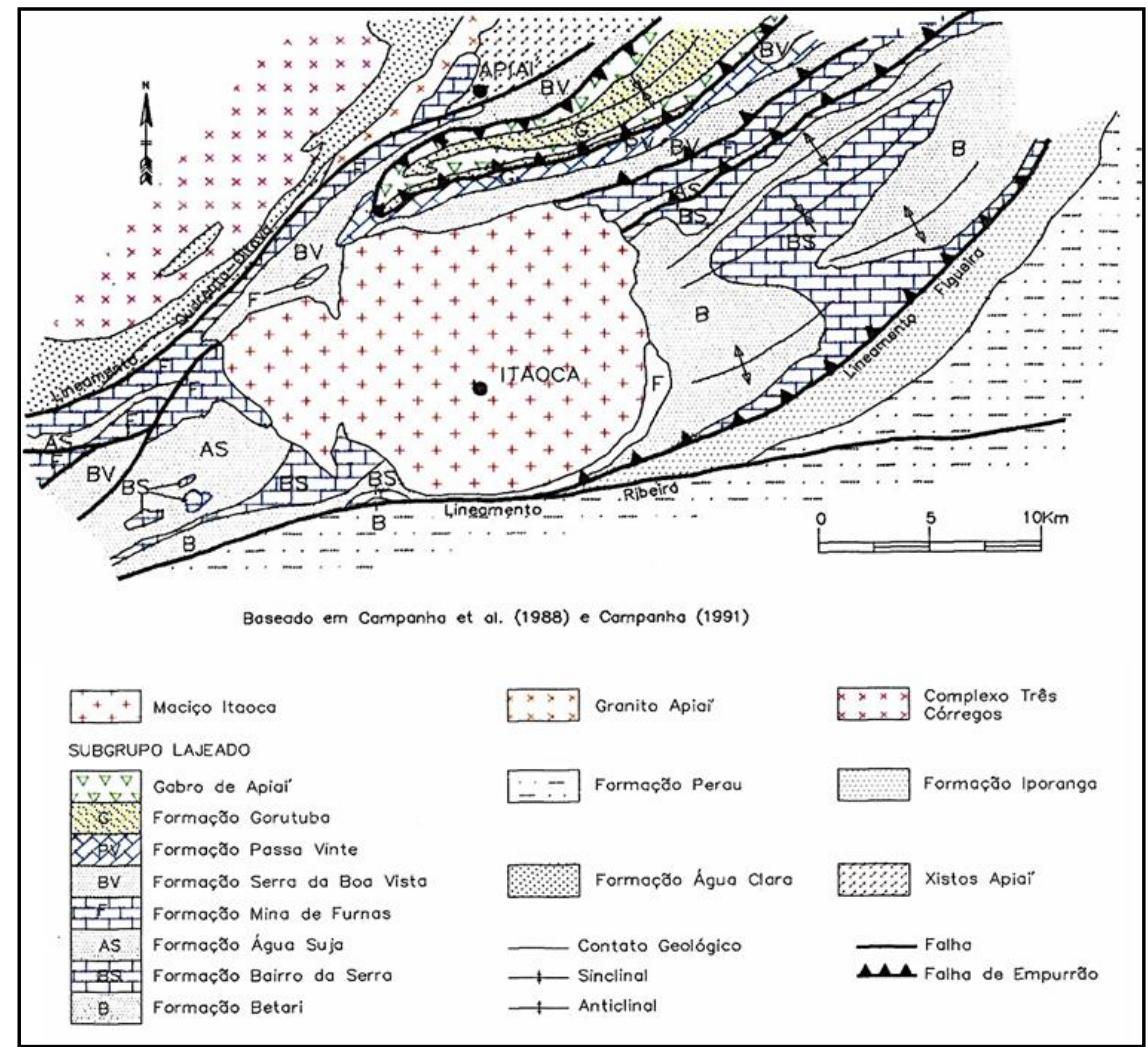

Fonte: Mello (1995).

Figura 3.18: Mapa Geológico de Itaoca.

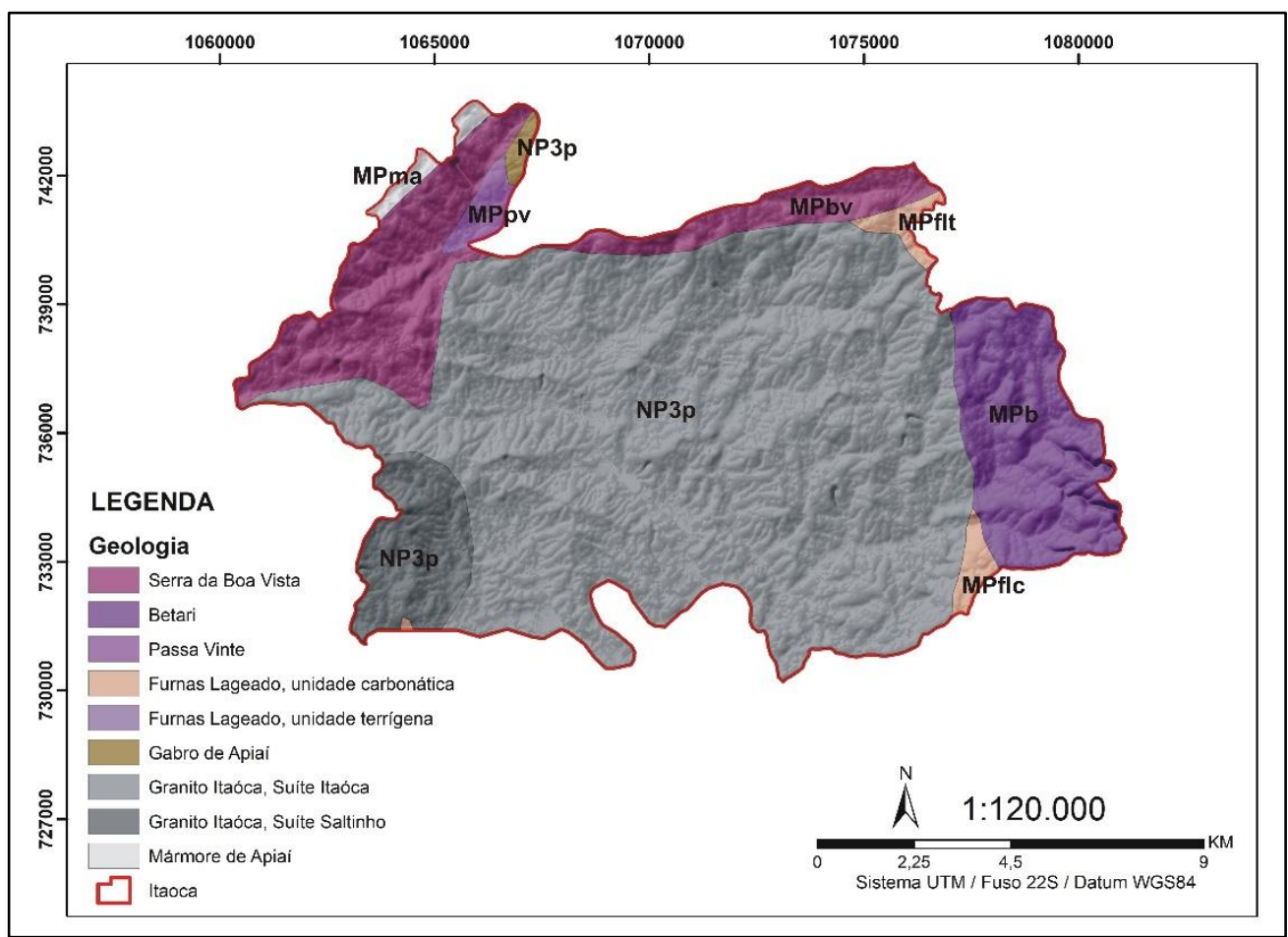

Fonte: Perrotta et al. (2005). 
O município está localizado no contexto geomorfológico da Serra do Mar e do Vale do Ribeira (ROSS, 2002), com características físicas favoráveis à ocorrência de processos de movimento de massa e inundações. Nesta região, o rio Ribeira exerce forte influência no modelado do relevo, juntamente com a geologia e erosão diferencial presente, interrompendo o traçado contínuo da Serra do Mar no litoral do Estado de São Paulo, que ressurge às divisas do Paraná (ALMEIDA, 1964). Ross (2002) classifica a região como “Unidade V: sistema de morros em superfície de cimeira do Alto Ribeira", como um ambiente montanhoso com topos nivelados nos divisores principais, em torno de $900 \mathrm{~m}$, podendo chegar a atingir $1.100 \mathrm{~m}$ nos setores mais elevados, conservados dada à presença de rochas de origem metamórficas mais resistentes. $\mathrm{O}$ autor também destaca a presença de vales profundos, com encostas inclinadas variando entre 30 e $60 \%$ de declividade. Segundo o Mapa Geomorfológico do IPT (1981), a região é composta em maior parte por montanhas na porção central do município e escarpas ao norte, na região da Serra da Boa Vista, nome local da Serra do Mar, com predomínio de topos angulosos, vertentes ravinadas com perfis côncavo-convexos, vales fechados e drenagem dendrítica (Figura 3.19).

Figura 3.19: Mapa Geomorfológico de Itaoca/SP.

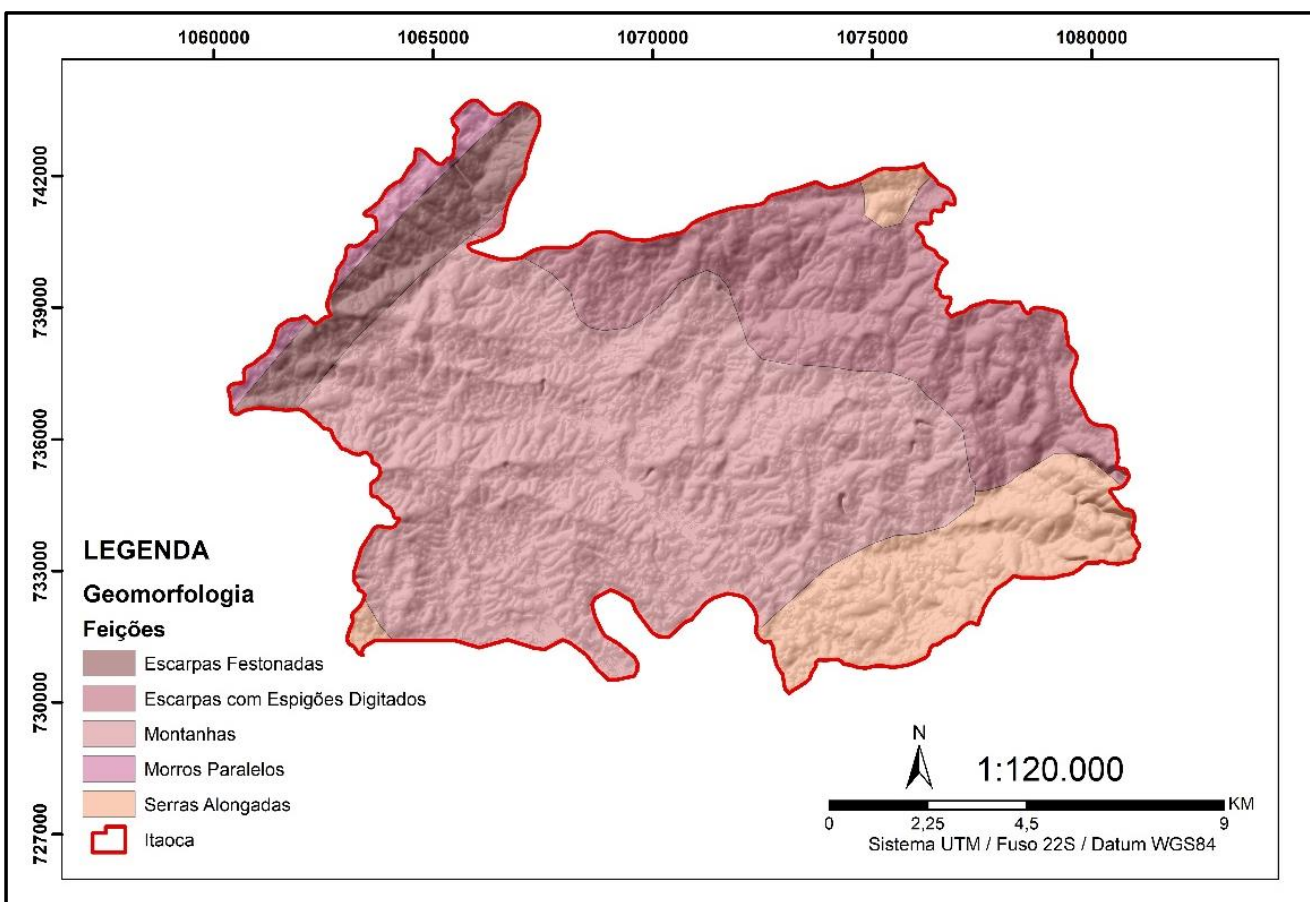

Fonte: IPT (1981). 
De acordo com a classificação de Koppen (1936), clima do município de Itaoca é do tipo Cfa, com temperatura média variando entre $25,3^{\circ} \mathrm{C}$, no mês mais quente, a $16,7{ }^{\circ} \mathrm{C}$, no mês mais frio, segundo média mensal entre os anos de 2011 e 2018 (CIIAGRO, 2018). As precipitações médias mensais variam entre $219,85 \mathrm{~mm}$ (janeiro) a 62,70 mm (julho), segundo média mensal entre os anos de 1970 e 2000. Se destacam os meses de dezembro, janeiro e fevereiro como os mais chuvosos (Figura 3.20).

Segundo o Inventário Florestal da Vegetação Nativa do Estado de São Paulo do Instituto Florestal do Estado de São Paulo (2009), as formações fitogeográficas presentes no município são a Floresta Ombrófila Densa, com áreas de transição para a Floresta Ombrófila Mista, podendo ser encontrada residualmente nos setores mais frios e altos da região. Com relação à cobertura pedológica, prevalecem nas encostas com maior inclinação e nas áreas de domínio dos quartzitos os Cambissolos associação com Neossolos e afloramentos rochosos. Já nos setores com menor inclinação, ocorrem os solos do tipo Argissolo Vermelho-amarelo e Latossolos Amarelos e Latossolos Vermelho-amarelos álicos de textura argilosa (ROSS, 2002; ROSSI, 2017).

Figura 3.20: Precipitações Médias Mensais em Itaoca durante o período de 1970-2000. Destaque para os meses de dezembro, janeiro e fevereiro, com os maiores valores.

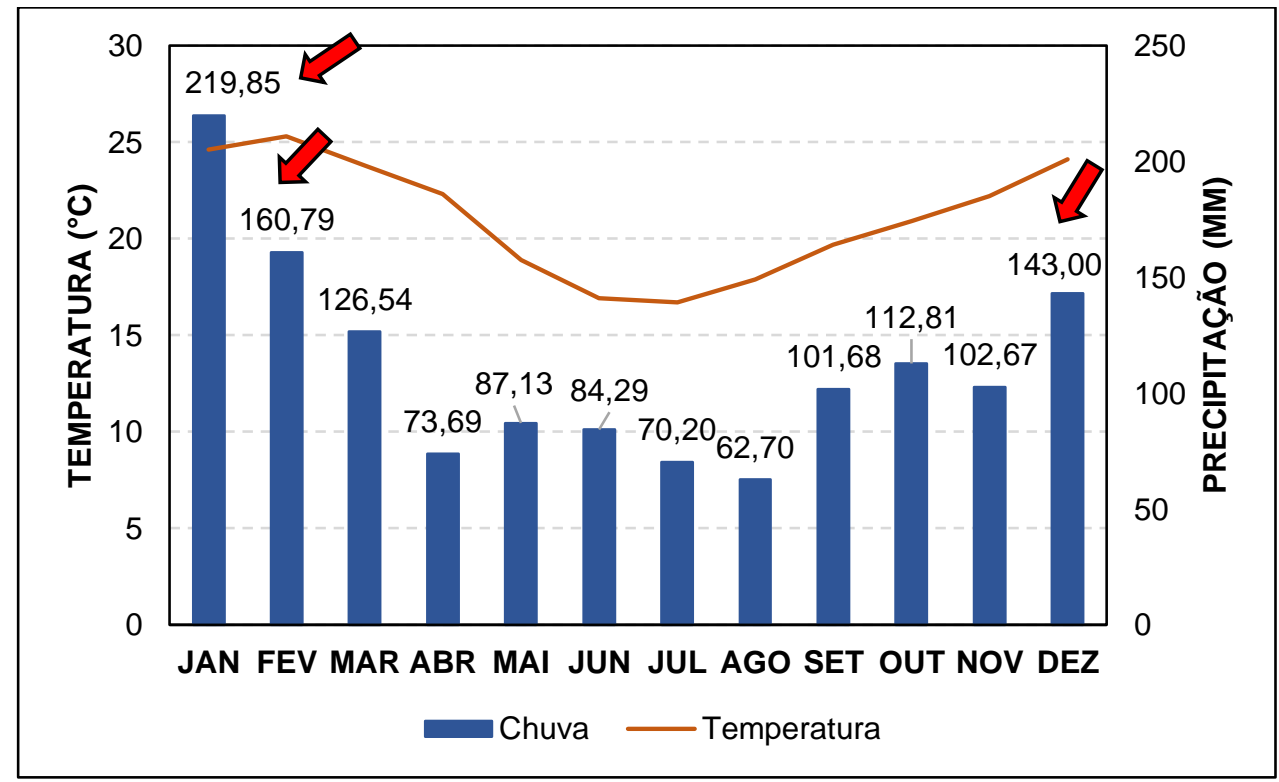

Fonte: DAEE (2018). 


\subsubsection{Evento de 2014}

Em 13 de Janeiro de 2014, evento pluviométrico extremo deflagrou escorregamentos e corridas de detritos no município de Itaoca, no interior do Estado de São Paulo (BROLLO et al., 2015; CAROU et al., 2017). As corridas de detritos foram deflagradas a partir do aporte de sedimentos e materiais oriundos dos escorregamentos nas encostas ao atingirem as drenagens já saturadas devido à elevado volume pluviométrico (GRAMANI; MARTINS, 2016). Segundo Gramani (2015), o processo causou intensas modificações na paisagem, destacando-se a intensa mobilização vegetal e o assoreamento de muitos pontos dos rios Palmital e Funil. Apesar de ter se iniciado em áreas elevadas do relevo, o processo atingiu o centro urbano do município, localizado nas porções mais baixas e planas do relevo, causando danos à infraestrutura local (Figura 3.21).

Figura 3.21: Processo de corridas de detritos em Itaoca. Escorregamentos deflagrados nas altas encostas deflagraram corridas de detritos nas drenagens, já saturadas pela chuva (a). Os detritos compostos por troncos e lama atingiram as porções mais baixas do relevo, causando dano à área urbana do município (b).

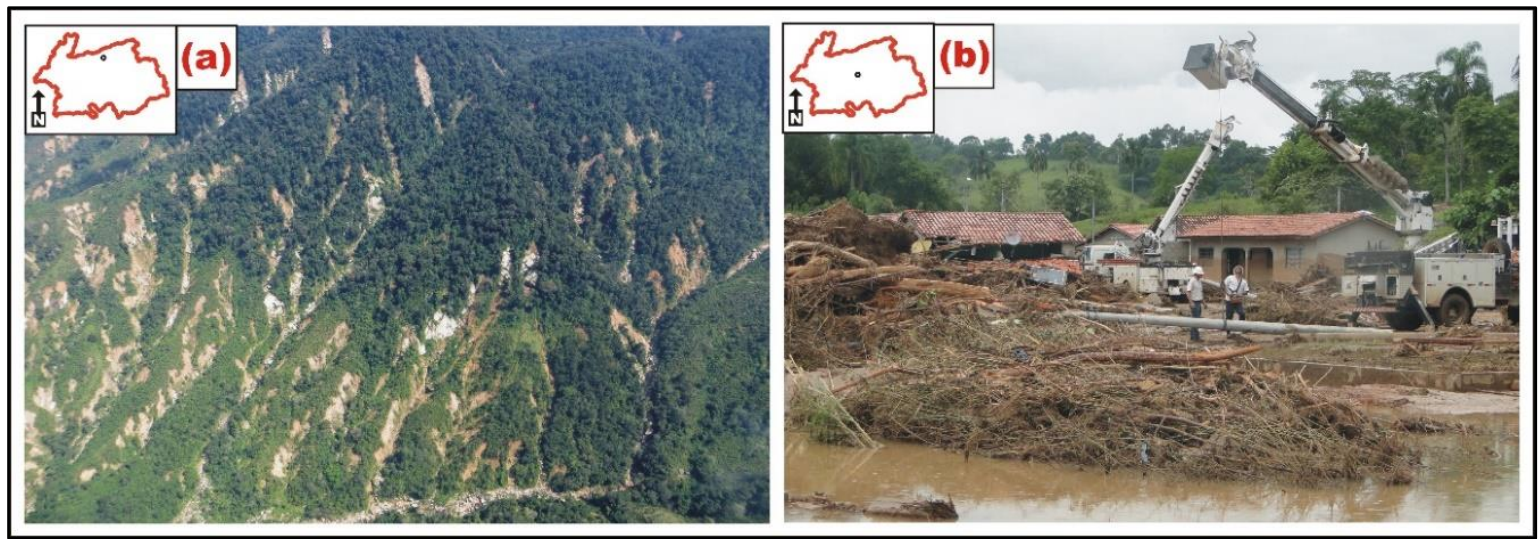

Fonte: Prefeitura do município de Itaóca.

Algumas bacias foram mais atingidas por escorregamentos (ex. Gurutuba), enquanto em outras houve o predomínio de corridas de detritos (ex. Guarda-mão), no entanto, a conjuntura dos dois processos nas bacias a montante contribuíram para o elevado volume de materiais que chegou até as porções mais baixas do relevo, atingindo o centro urbano do município. A matéria orgânica, que atingiu as porções mais planas do relevo, na área urbana do município, foi transportada majoritariamente pelo rio Palmital (GRAMANI, 2015; MATOS et al., 2018) (Figura 3.22). 
Figura 3.22: Matéria orgânica composta majoritariamente por troncos de árvores e galharia, que atingiram o centro urbano do município.

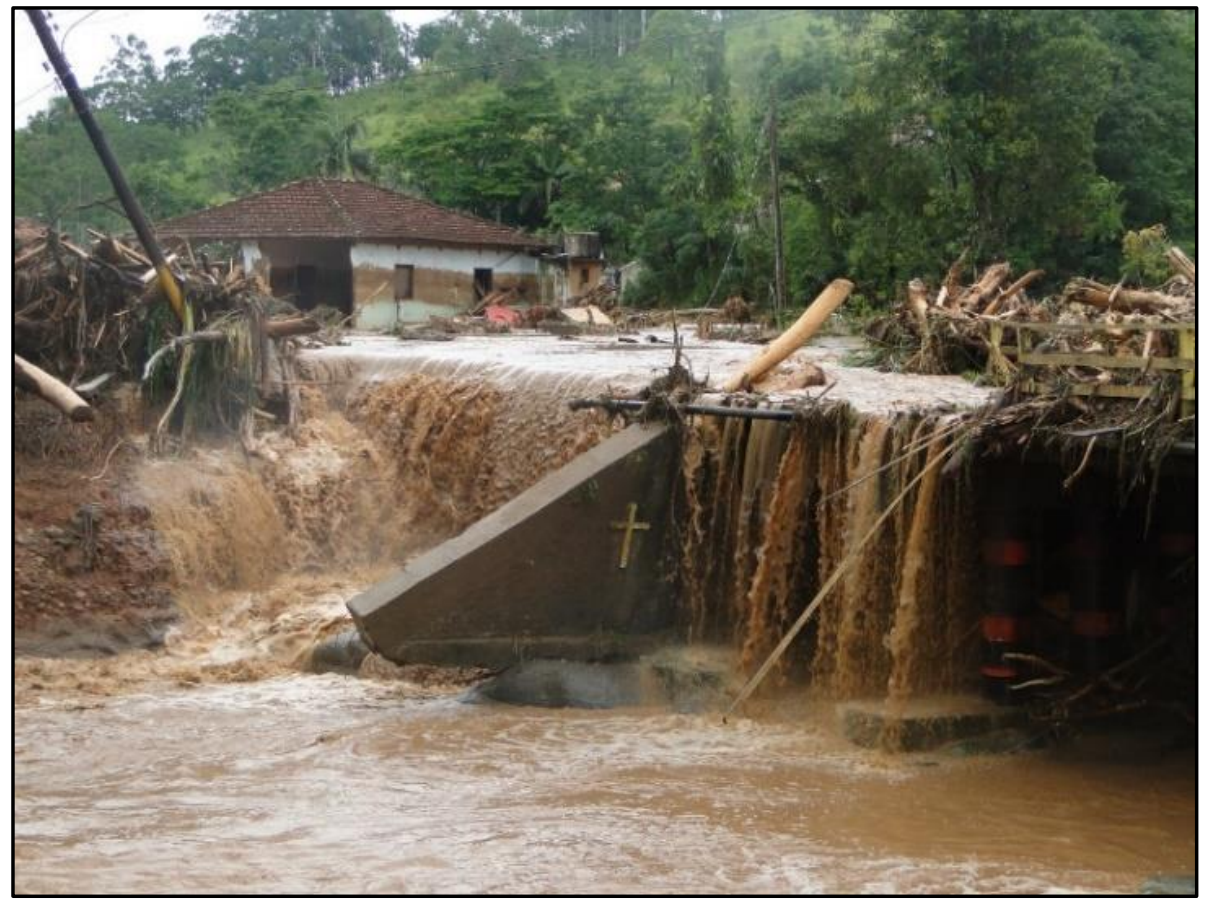

Fonte: Prefeitura Municipal de Itaoca. 


\subsubsection{Bacia do rio Guarda-mão I}

A bacia Guarda-mão I (Figura 3.23) possui $3,74 \mathrm{~km}^{2}$ e $4^{\circ}$ ordem na hierarquização de drenagem de Strahler $(1952,1957)$. A bacia foi uma das mais atingidas pelo processo, se destacando devido ao tamanho e volume dos materiais transportados (blocos e matéria orgânica) (BROLLO et al., 2015; GRAMANI; ARDUIN, 2015; GRAMANI; MARTINS, 2016).

Figura 3.23: Bacia Guarda-mão I, no município de Itaoca, Estado de São Paulo.

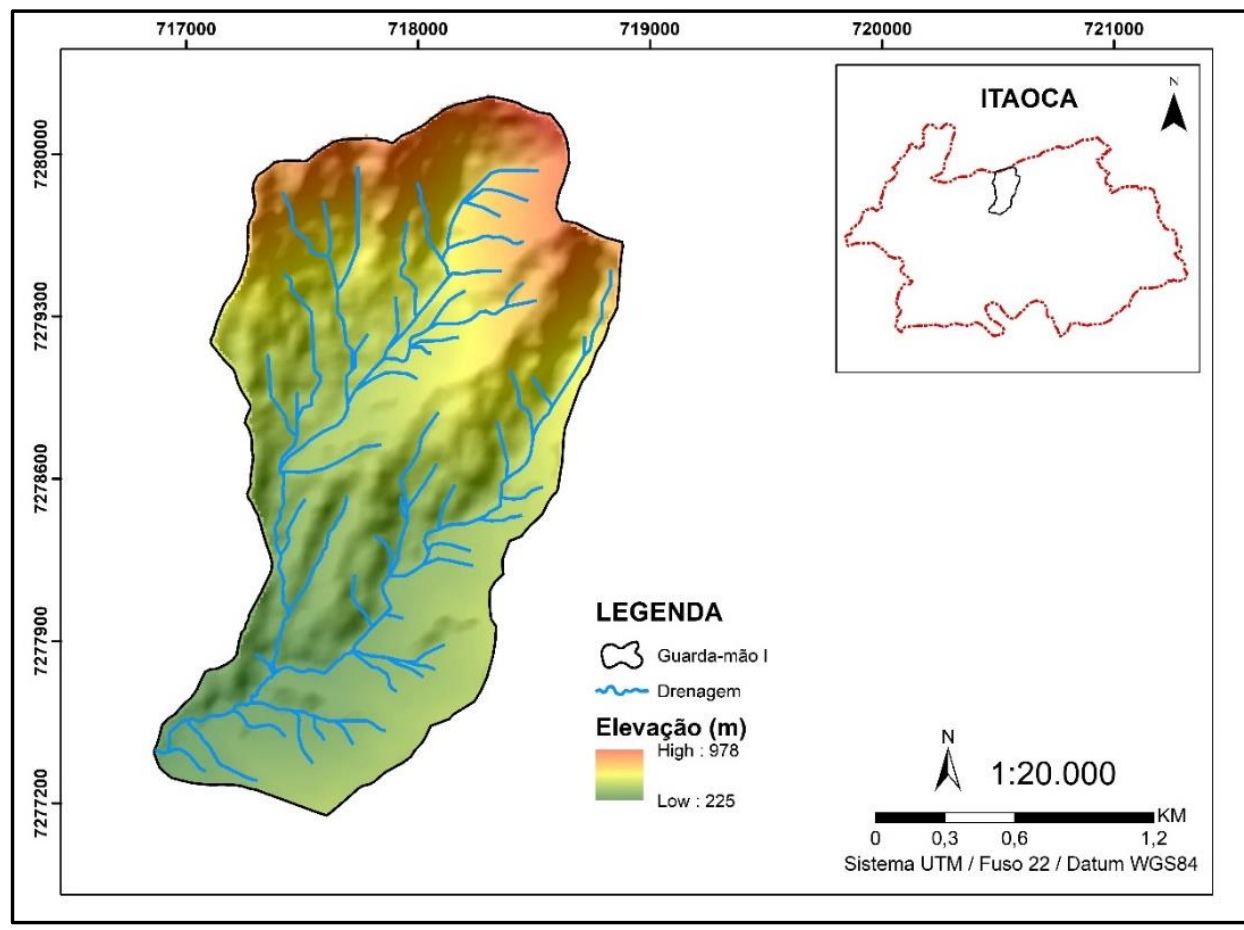

As corridas de detritos foram deflagradas pelo aporte de materiais oriundos dos escorregamentos, que atingiram as drenagens já saturadas, e remobilização de materiais já localizados na drenagem, provocando erosão das margens ao longo de seu trajeto (Figura 3.24). A corrida atingiu as porções mais baixas do relevo, causando danos às moradias e intensa modificação na paisagem, com a deposição de blocos com tamanho superior à $2 \mathrm{~m}$ de diâmetro (Figura 3.25). 
Figura 3.24: Bacia Guarda-mão I. Corridas de detritos deflagradas pelo aporte de escorregamentos nas alta encostas (a). Detalhe para as cicatrizes dos escorregamentos e da erosão provocada pelas corridas de detritos (b).

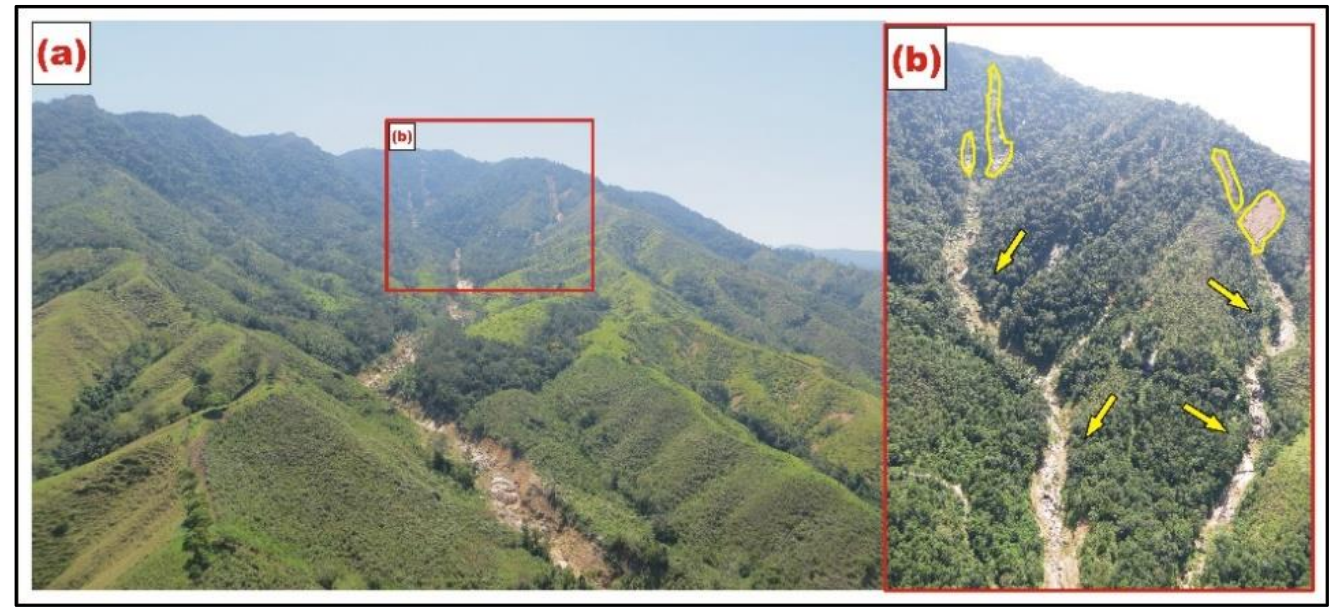

Fonte: fotografias de Gramani, M. F. (2014).

Figura 3.25: Depósito de corridas de detritos na planície da bacia do Guarda-mão I, em Itaoca/SP.

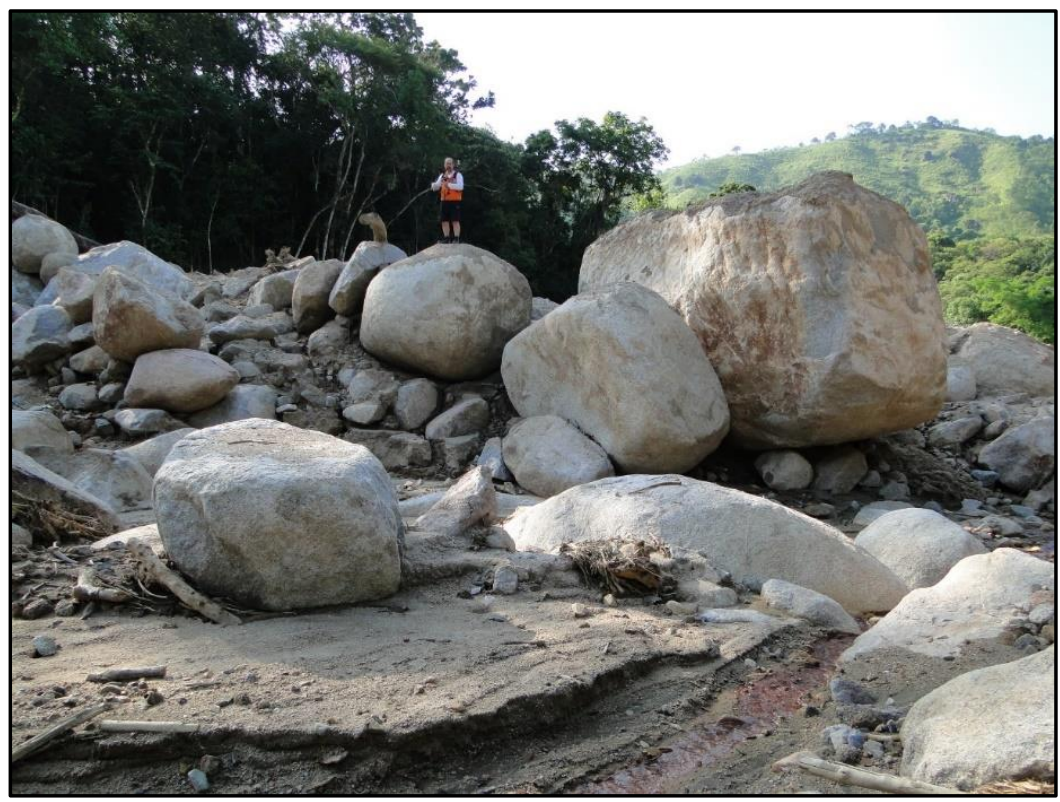

Fonte: fotografias de M. F. Gramani (2014).

Com base em VanDine (1985), Gramani; Martins (2015) fizeram a setorização da ocorrência na bacia Guarda-mão I, subdividindo-a em 3 setores (Tabela 3.2), que podem ser definidos como área de iniciação, transporte inicial e erosão (zona 1), sendo composta por cicatrizes de escorregamentos nas alta encostas como área fonte de materiais e intensa erosão causada pelo fluxo ao longo do canal; área de deposição inicial (zona 2), composta majoritariamente por materiais grosseiros e blocos de tamanho "gigante"; e área de deposição 
fina (zona 3), com predomínio de depósitos compostos por matéria orgânica e sedimentos finos (Figura 3.26).

Tabela 3.2: Caracterização das corridas de detritos na bacia Guarda-mão I, em Itaoca.

\begin{tabular}{cl}
\hline SETOR & \multicolumn{1}{c}{ CARACTERÍSTICAS } \\
\hline 1 & $\begin{array}{l}\text { Zona inicial, em encostas com ângulo acima de } 25^{\circ} \text {, caracterizada pela } \\
\text { presença de cicatrizes dos escorregamentos e erosão do canal por onde o } \\
\text { fluxo passou. }\end{array}$ \\
\hline 2 & $\begin{array}{l}\text { Encostas com inclinação média de } 10^{\circ} \text {, sendo área fonte de materiais } \\
\text { (erosão) e transporte. Aqui ocorreu a deposição inicial de blocos com mais } \\
\text { de } 2 \text { metros de diâmetro. }\end{array}$ \\
\hline 3 & $\begin{array}{l}\text { Encostas com inclinação menor que } 3^{\circ} \text {, sendo a área de deposição final, com } \\
\text { predomínio de sedimentos finos. }\end{array}$ \\
\hline
\end{tabular}

Fonte: Copilado a partir de Gramani; Martins (2015).

Figura 3.26: Características das corridas de detritos na bacia Guarda-mão I, segundo setorização de Gramani; Martins (2015). Setor 1 (a), iniciação do processo, transporte inicial e erosão; Setor 2 (b), deposição inicial, com blocos de tamanho "gigante"; Setor 3 (c), deposição final, com sedimentos mais finos e matéria orgânica, e imagem aérea de 2019 da transição entre os setores 2 e 3 (d), com destaque para tamanho do carro, que serve como escala.

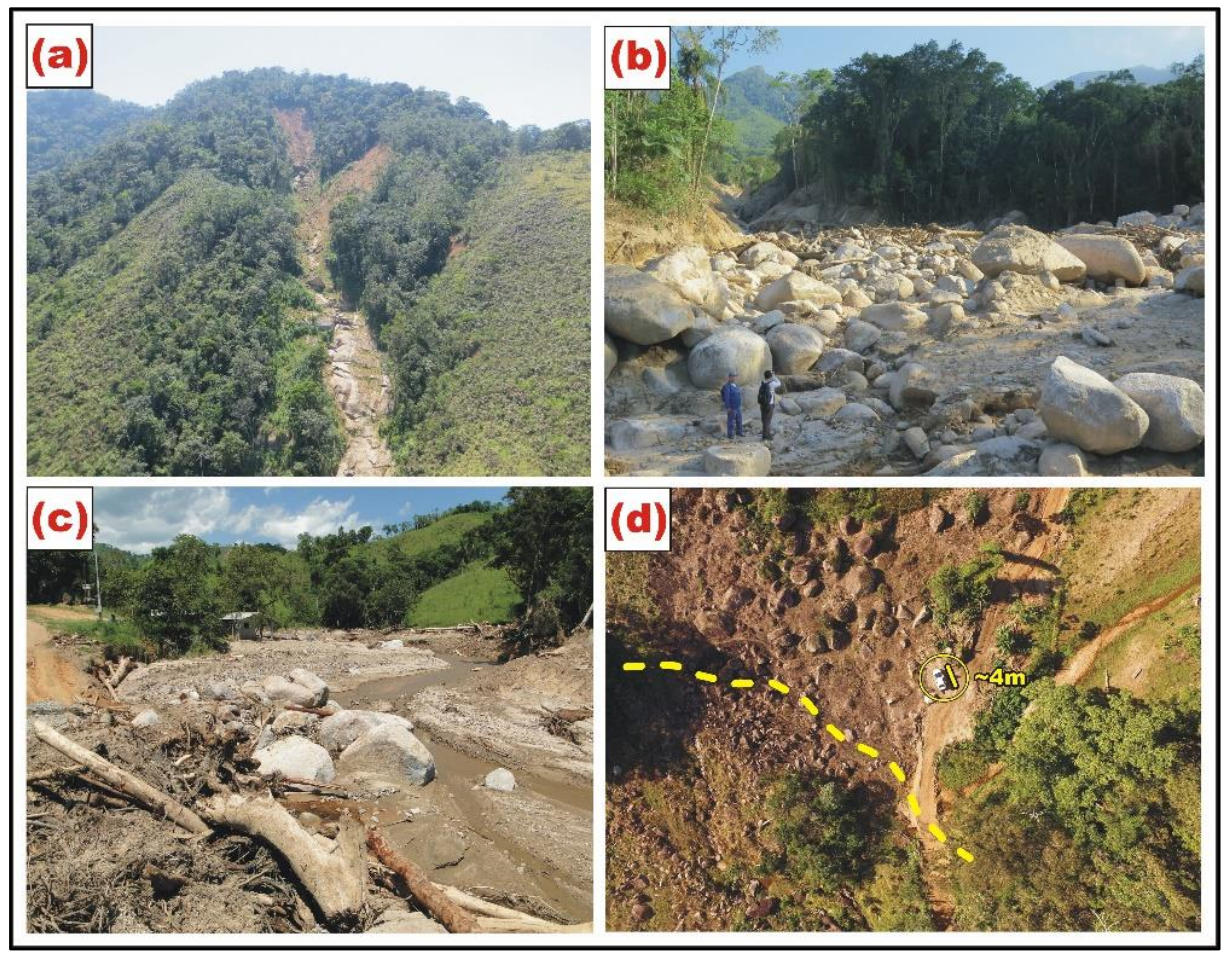

Fonte: fotografias de M. F. Gramani (2014; 2019). 


\subsubsection{Bacia Gurutuba}

A bacia Gurutuba (Figura 3.27) possui $4,52 \mathrm{~km}^{2}$ e $4^{\circ}$ ordem na hierarquização de drenagem de Strahler (1952, 1957). Carou et al., (2017) mapearam 336 cicatrizes na bacia, cujos tamanhos variaram entre $13 \mathrm{~m}^{2}$ e valores acima de $900 \mathrm{~m}^{2}$, chegando até $5.548 \mathrm{~m}^{2}$ (Figura 3.28), o que gerou elevado volume de sedimentos, que, todavia, não contribuíram para a deflagração de corridas de detritos significativas na mesma. A bacia Gurutuba será uma das áreas não-afetadas na ocasião deste evento a serem avaliadas.

Figura 3.27: Bacia Gurutuba, localizada na região da Serra do Mar, no município de Itaoca, Estado de São Paulo.

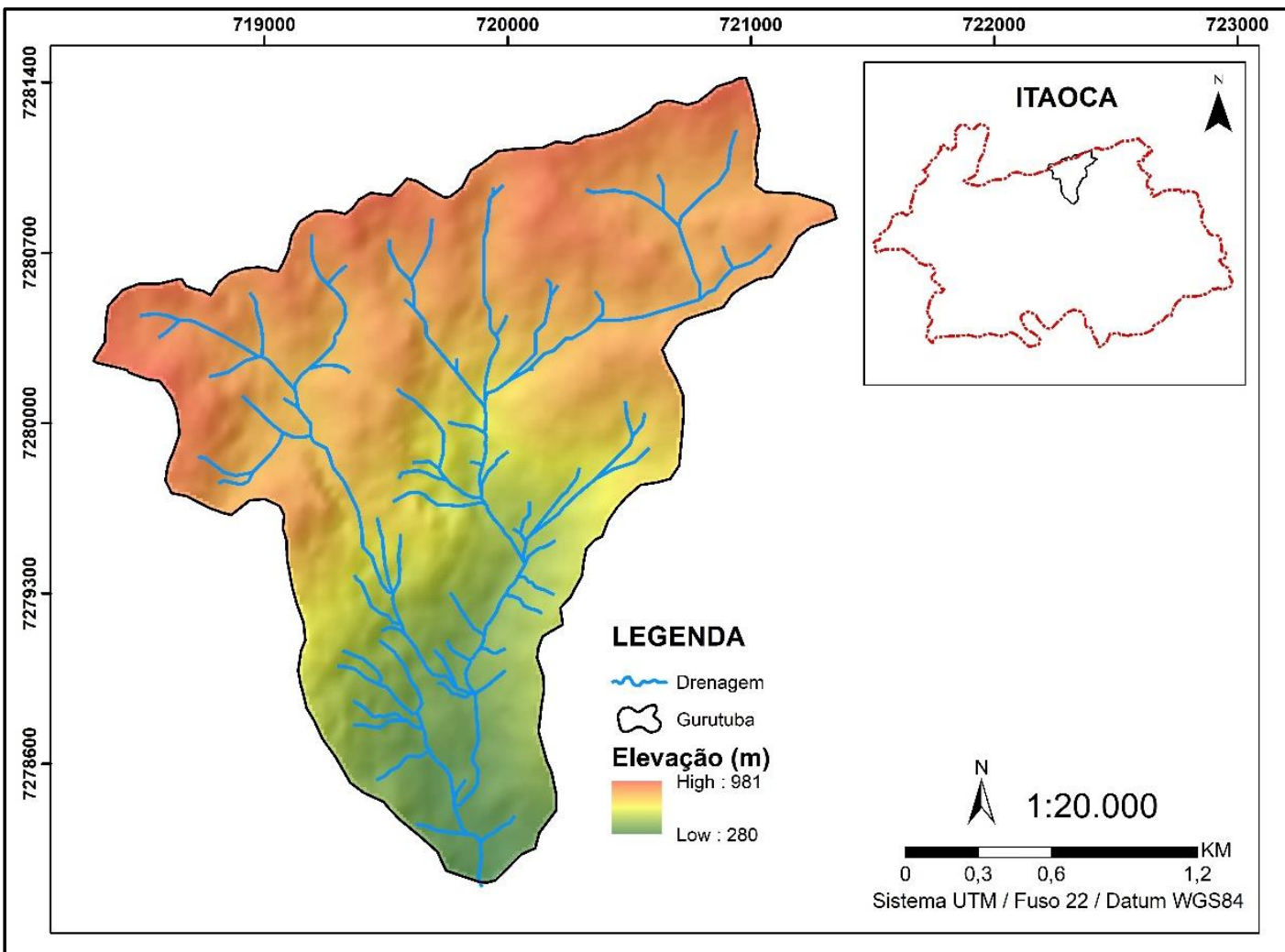


Figura 3.28: Bacia Gurutuba. Grande quantidade de escorregamentos nas encostas (a). Detalhe para o tamanho das cicatrizes de escorregamentos (b).

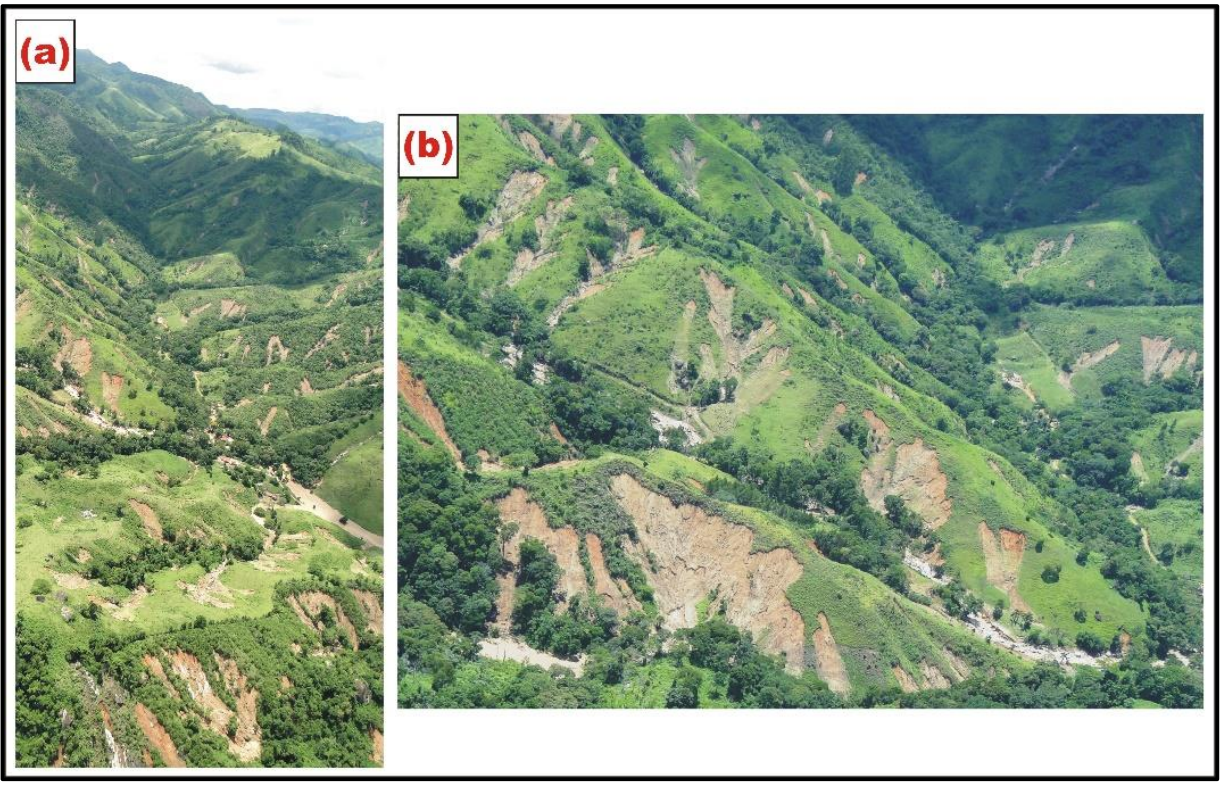

Fonte: Prefeitura do Município de Itaoca (2014). 


\subsubsection{Bacia Guarda-mão II}

A bacia Guarda-mão II está localizada à oeste da bacia Guarda-mão I, sendo contígua à mesma. (Figura 3.29). Possui $2,55 \mathrm{~km}^{2}$ e $4^{\circ}$ ordem na hierarquização de drenagem de Strahler (1952, 1957). À ocasião de evento de 2014, não foram deflagrados na bacia corridas de detritos e escorregamentos rasos, apesar da mesma ter sido afetada por volume pluviométrico similar à bacia Guarda-mão I. Dessa forma, a área foi selecionada como uma das bacias não-afetadas por corridas de detritos na ocasião do evento de 2014 em Itaoca para avaliação.

Figura 3.29: Bacia Guarda-mão II, localizada na região da Serra do Mar, no município de Itaoca, Estado de São Paulo.

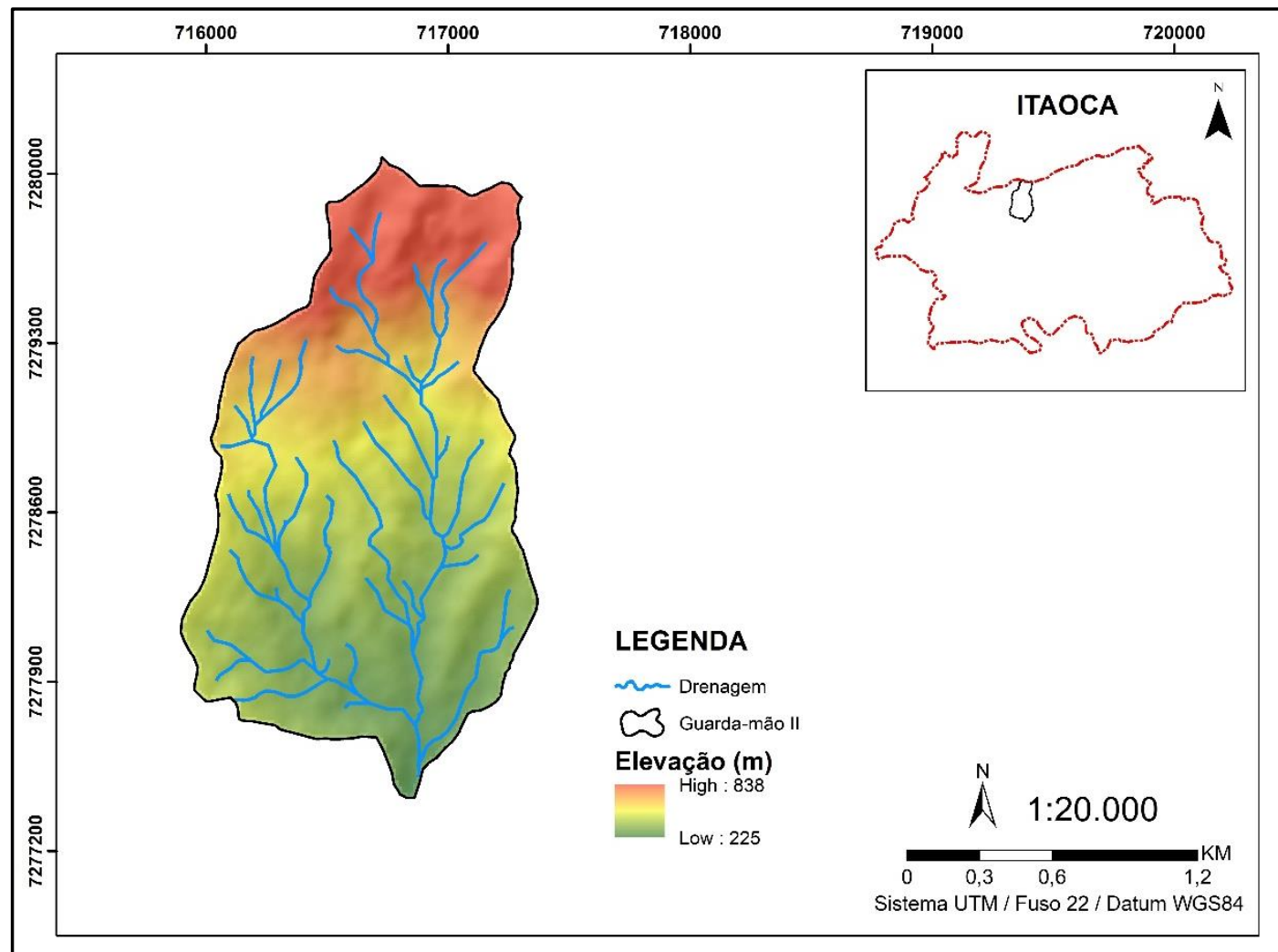




\section{CARACTERIZAÇÃO DAS CORRIDAS DE DETRITOS NA SERRA DA PRATA (2011) E EM ITAOCA (2014): MORFOLOGIA DOS DEPÓSITOS E MAGNITUDE ${ }^{6}$}

A caracterização de eventos pretéritos é uma etapa fundamental da avaliação da suscetibilidade a movimentos de massa, sobretudo, no caso das corridas de detritos. Da mesma forma que o mapa de inventário de escorregamentos é parte principal nos estudos a respeito do processo, a evidenciação de particularidades referentes às corridas de detritos (ex. volume, velocidade, pico de vazão, características dos depósitos) é indispensável para estudos futuros concernente ao mesmo. Embora tenha ocorrido um avanço nos mapeamentos e desenvolvimento de políticas governamentais relacionados à mitigação dos movimentos de massa, as corridas de detritos ainda carecem de estudos mais detalhados a respeito de sua dinâmica em território nacional. Dessa forma, este capítulo busca auxiliar na descrição e disseminação de informações a respeito eventos recentes de corridas de detritos no país, comparando os principais fatores deflagradores e características geomorfológicas de dois eventos recentes de corridas de detritos ocorridos na Serra do Mar.

\subsection{Metodologia}

\subsubsection{Mapeamento dos depósitos}

As corridas de detritos possuem características intrínsecas à dinâmica do fluxo, que permanecem evidentes após sua ocorrência na forma de depósitos, como uma espécie de "assinatura" que contribuí para a identificação de eventos pretéritos. Características como a presença de inversão granulométrica (quando blocos maiores ficam "suspensos" pelos sedimentos mais finos); presença de materiais mal selecionados; blocos muito grandes, que não poderiam ser transportados por outros tipos de processos, tais como enxurradas; e presença de percurso bem definido e depósitos do tipo "levees", ou "ondas laterais" (geralmente localizados nas margens do canal por onde o fluxo passou) indicam a ocorrência de corridas de detritos (Tabela 4.1). Outras características, como a presença de imbricamento (quando os blocos possuem uma orientação predominante), podem indicar tratar-se de outro tipo de processo, e não corridas de detritos (JAKOB, 2005a). Além de proporcionar a identificação de áreas onde já ocorreram corridas de detritos, o mapeamento das feições dos depósitos fornece um

\footnotetext{
${ }^{6}$ Os resultados contidos neste capítulo foram submetidos para avaliação no artigo "Geomorphic analyses of recent debris flows in Brazil".
} 
panorama a respeito das características das ocorrências em território nacional, compondo uma espécie de inventário sobre o processo, que pode vir a ser utilizado em eventuais trabalhos voltados à mitigação e ao planejamento territorial.

Tabela 4.1: Identificação de evidências morfológicas de corridas de detritos na paisagem.

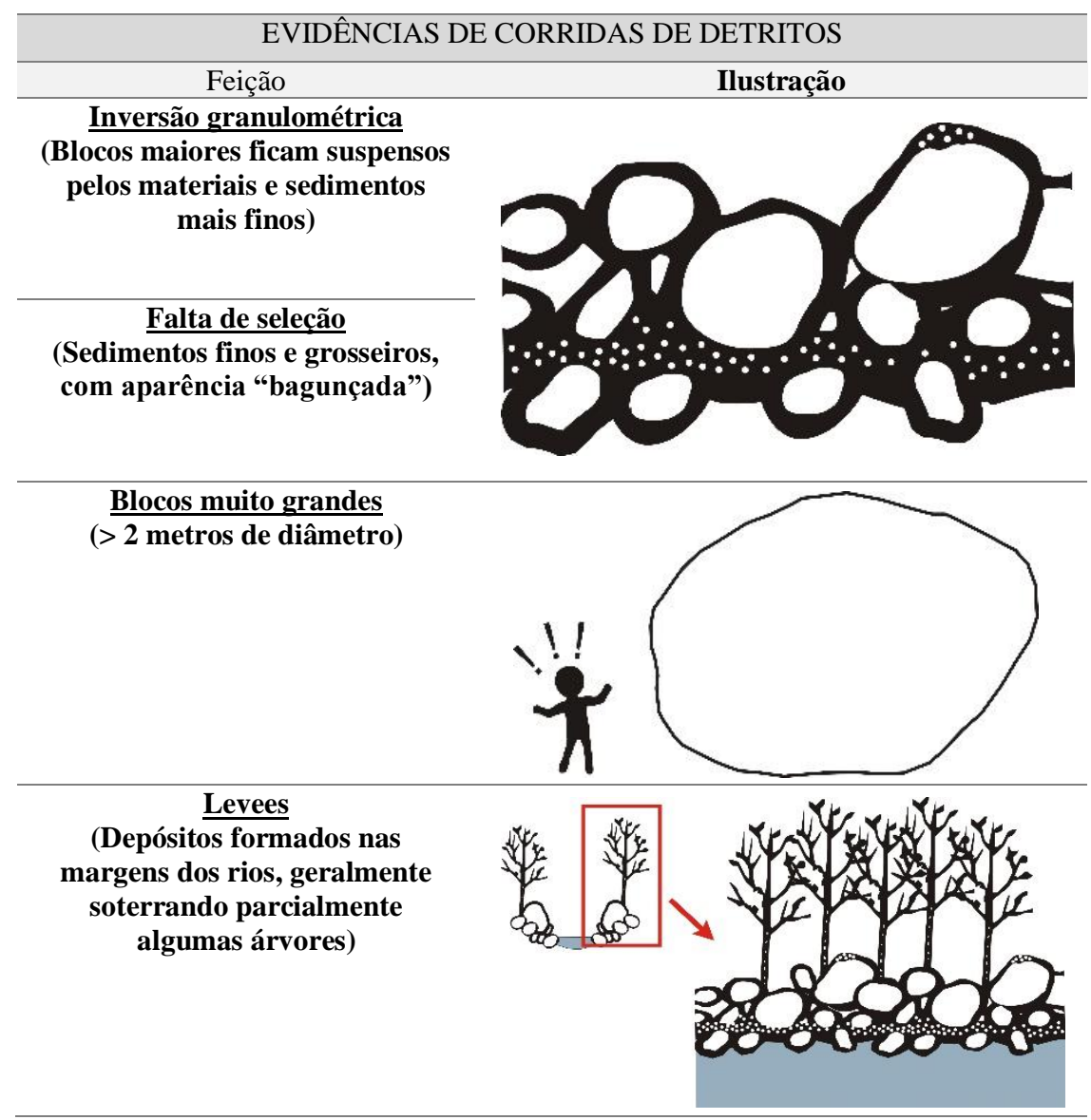

Durante o mapeamento dos depósitos foram verificadas em vistorias de campo (Figura 4.1) as características dos depósitos do ponto de vista morfológico, o tamanho dos blocos presentes no mesmo, e sua localização. Para tal, foi utilizada uma ficha de classificação dos depósitos (Figura 4.2), nas quais são identificadas as características dos depósitos (presença de imbricamento, inversão granulométrica etc.), o tamanho dos blocos (pequeno, médio, grande ou muito grande) e demais informações (localização, croqui, outras características etc.).

A localização das seções e dos depósitos mapeados em campo variou em cada uma das bacias devido às dificuldades de acesso. Na bacia Tingidor, foi possível o acesso apenas a chamada "zona de deposição", enquanto na bacia Guarda-mão I o acesso à setores a montante foi facilitado devido à construção de estradas relacionadas a atividades agrícolas na área. Além disso, a identificação de algumas feições foi dificultada devido à rápida regeneração da 
cobertura vegetal mais densa (Figura 4.3). No total, foram mapeados 8 setores na bacia Guardamão I e 6 setores na bacia Tingidor.

Figura 4.1: Mapeamento dos depósitos na bacia Tingidor, na Serra da Prata/Paraná.

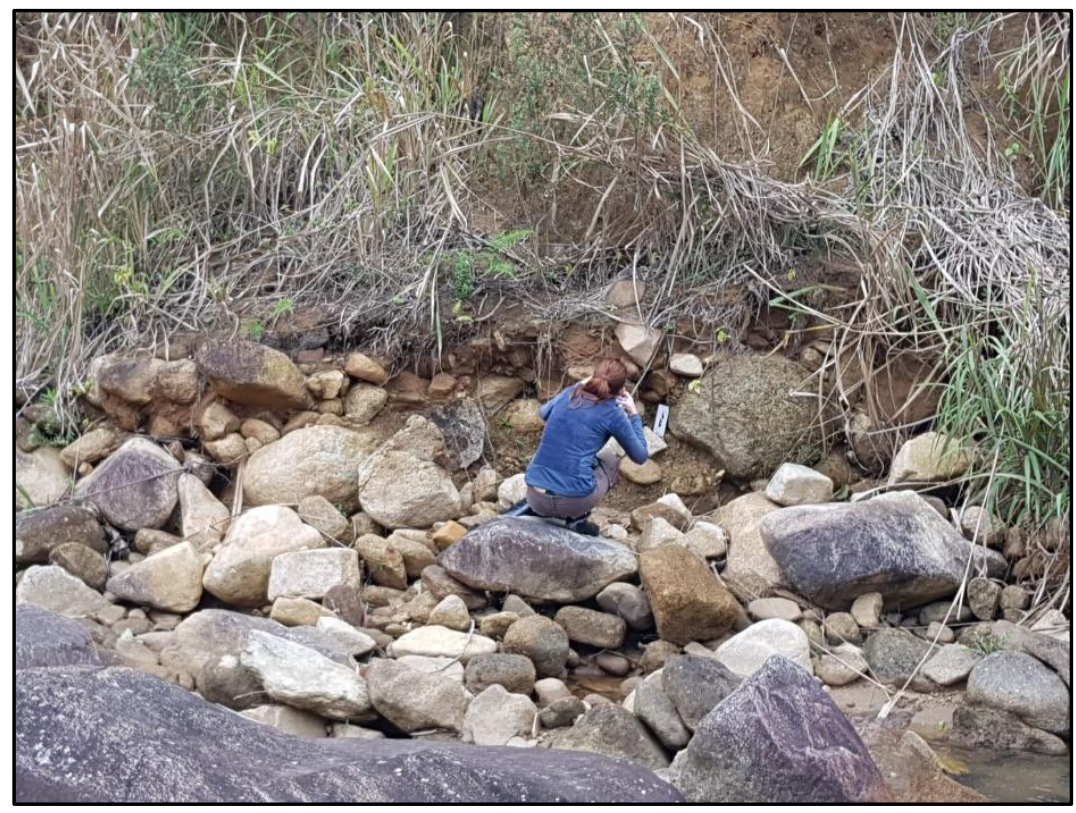

Figura 4.2: Ficha de mapeamento dos depósitos de corridas de detritos.

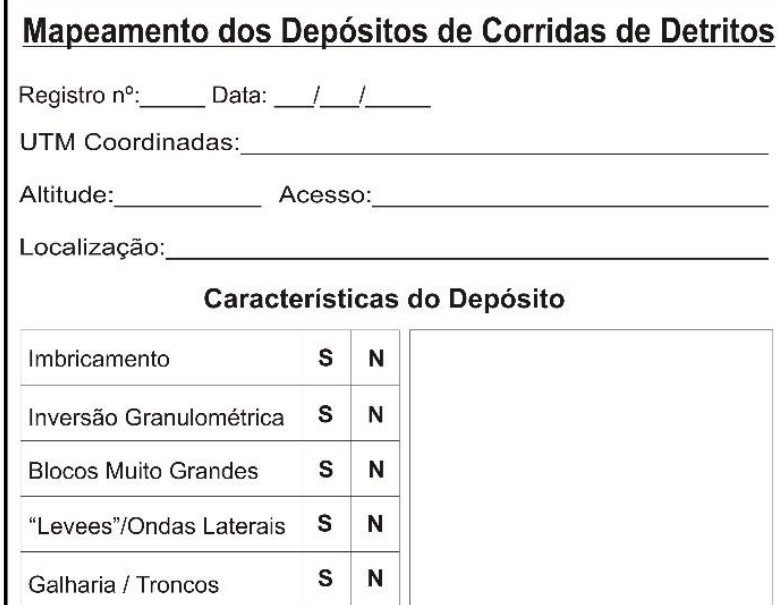

Tamanho dos blocos presentes no depósito

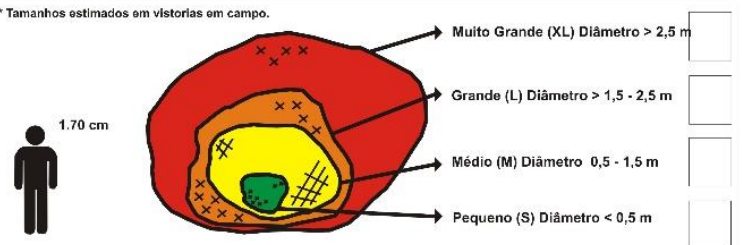

Outras Observações 
Figura 4.3: Depósitos de corridas de detritos na bacia Guarda-mão em 2014 (a) e a mesma área quase totalmente coberta pela vegetação em 2017 (b).

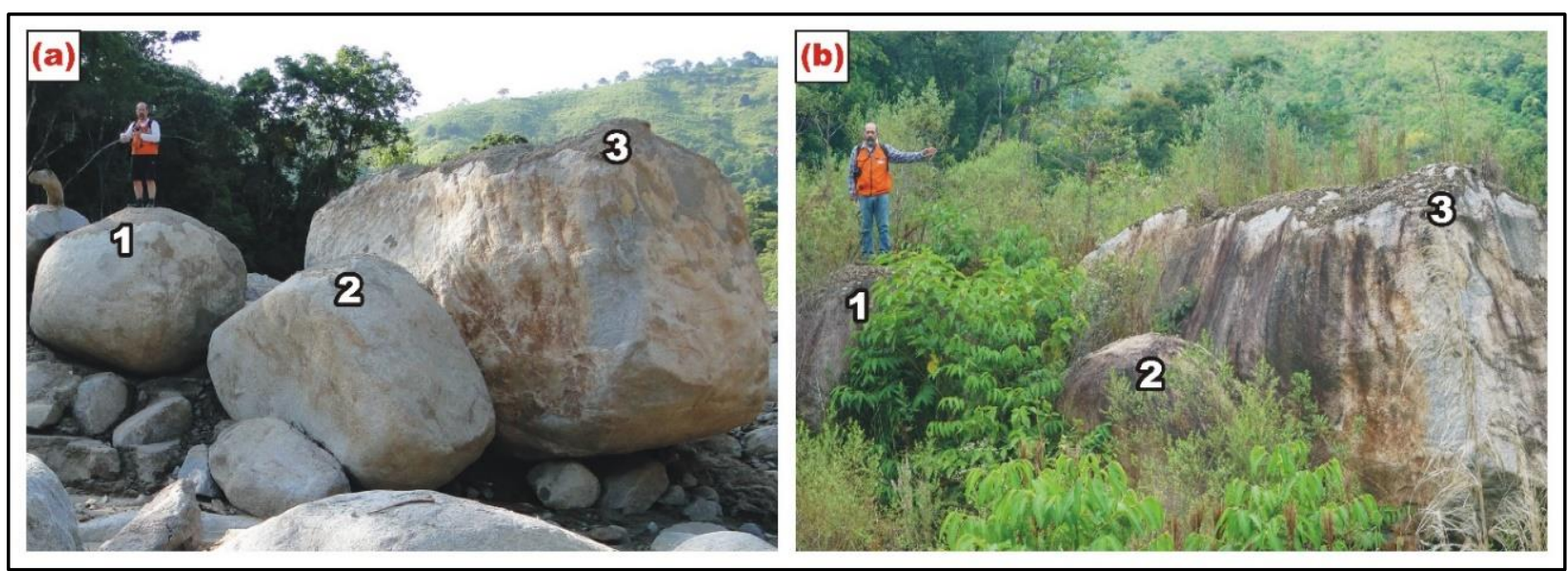

Fonte: fotografias de Gramani, M. F. (2014; 2017).

\subsubsection{Inventário de corridas de detritos (runout) e escorregamentos (cicatrizes)}

Para a realização do mapeamento do "runout" das corridas de detritos e cicatrizes dos escorregamentos foram utilizadas imagens de satélite do Google Earth datadas logo após os eventos extremos. As imagens foram georreferenciadas e o mapeamento foi feito no software ArcGIS 10.2. A metodologia adotada para delimitação das cicatrizes foi a mesma utilizada em outros trabalhos já realizados na Serra do Mar, como Carou et al. (2017); Dias et al. (2021a) e Vieira et al. (2018), que leva em consideração a ausência de vegetação e posição da encosta, sendo considerado o terço superior da encosta como área deslizada. Já com relação ao percurso ou "runout" das corridas de detritos, foi levado em consideração a erosão das margens do canal, provocada pela passagem do fluxo, e a presença de depósitos ainda visíveis na imagem (Figura 4.4). 
Figura 4.4: Mapeamento do "runout" das corridas de detritos e cicatrizes dos escorregamentos (a). No caso das corridas de detritos, foi considerado o trabalho erosivo realizado pelo fluxo ao passar pelo canal e a presença de depósitos ainda visíveis; no caso dos escorregamentos, foram considerados a ausência de vegetação e posição da encosta (b).

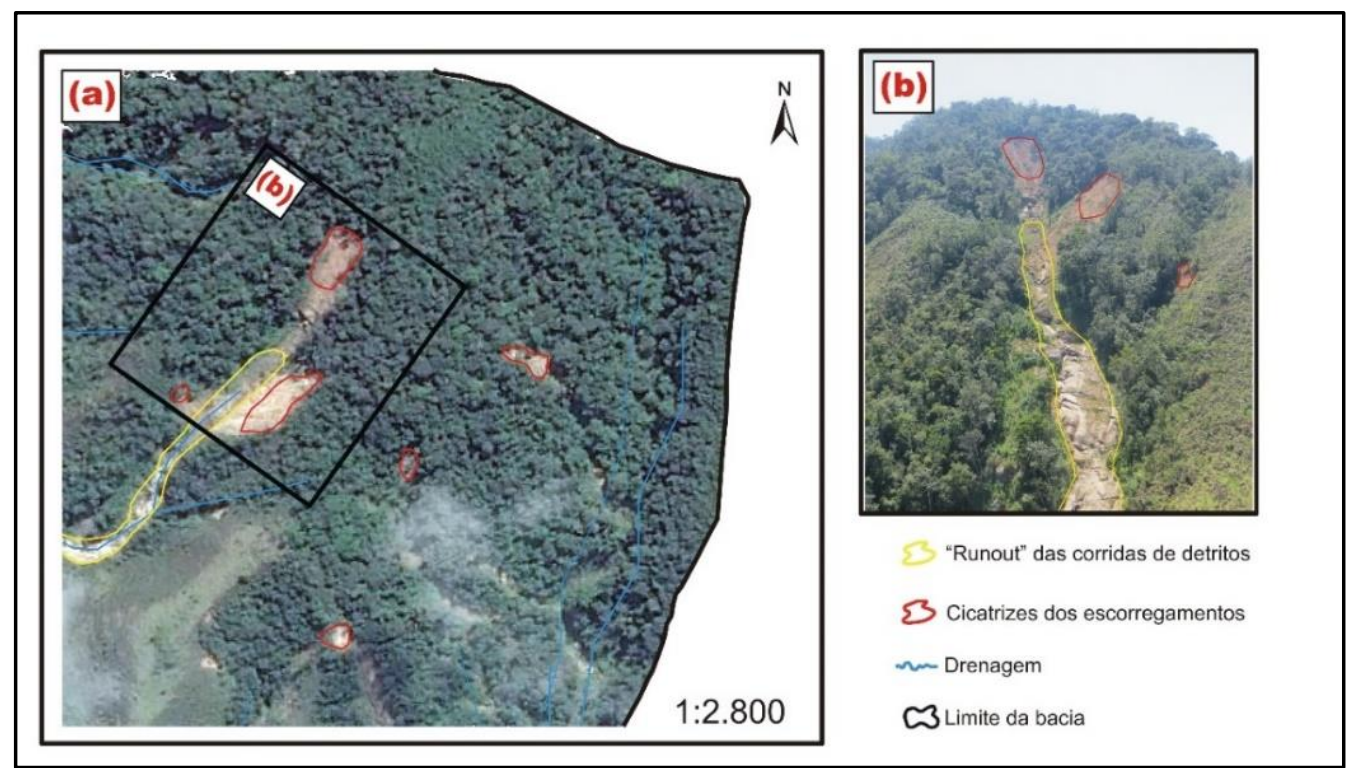

Fonte: Google Earth - CNES/Airbus (imagem de 08/10/2014) (a) e Gramani, M. F. (2014) (b).

\subsubsection{Pico de vazão e velocidade}

O Q e a U foram estimados para cada seção mapeada em campo utilizando a equação de Manning (Equação):

Equação 4.1: Equação de Manning para cálculo de vazão de pico.

$$
Q=\left(\frac{1}{n}\right) \times A \times R_{n}^{\frac{2}{3}} \times \sqrt{J}
$$

Equação 4.2: Equação de Manning para cálculo da velocidade.

$$
U=\frac{Q}{A}
$$

Na qual:

$n$ : é o coeficiente de rugosidade de Manning,

$A$ é a área da seção transversal $\left(\mathrm{m}^{2}\right)$,

$R_{n}$ é o raio hidráulico (m), e

$J$ é o gradiente do canal (graus). 
Diversos autores demonstraram a aplicabilidade da equação na estimativa de velocidade e da vazão de pico de corridas de detritos utilizando o valor 0.1 para $n$ (Xu and Feng 1979; Pierson 1986; Rickenmann and Zimmermann 1993; Rickenmann 1999; Cui et al. 2013; GarcíaDelgado et al. 2019).

\subsubsection{Estimativa de volume e determinação da magnitude}

Levando em consideração a forma como as corridas de detritos são deflagradas no Brasil, foi realizado o cálculo do volume do material mobilizado pelos escorregamentos $\left(V_{c}\right)$. Para isso, foi utilizada a equação proposta por Augusto Filho (1993) (Equação 4.3), que leva em consideração a área da cicatriz e estipula a espessura média de 1,0 metro para a ruptura, que é, segundo o autor, aproximadamente o valor de 50\% das rupturas observadas na Serra do Mar.

Equação 4.3: Volume cicatrizes de escorregamentos.

$$
V_{c}=A c \cdot 1,0
$$

Na qual:

$A c$ : é a área da cicatriz $\left(\mathrm{m}^{2}\right) ; \mathrm{e}$

1,0 metros é a espessura média de ruptura (m).

Para o cálculo do volume do depósito principal $\left(V_{d p}\right)$, Augusto Filho (1993) propõe a mesma relação citada anteriormente, alterando apenas o valor a qual a área do depósito será multiplicada. Utilizando como base a espessura média de depósitos verificados na Serra do Mar, o autor estipula a espessura média de deposição em 1,0 metro. No caso das áreas aqui estudadas, levando em consideração a espessura dos depósitos observados em campo nas duas bacias, estimou-se o valor médio 3,0 metros de espessura para o cálculo do volume de deposição final (Equação 4.4).

Equação 4.4: Volume depósito principal.

$$
V_{d p}=A d \cdot 3,0
$$

Na qual:

$A d$ : é a área do depósito $\left(\mathrm{m}^{2}\right) ; \mathrm{e}$

3,0 é a espessura média dos depósitos observados em campo (m). 
Além do chamado volume inicial $\left(V_{i}\right)$, representado pelo material mobilizado pelos escorregamentos, o cálculo do volume das corridas de detritos deve levar em consideração o material gerado pelo arrastamento da corrida ao longo do canal, até sua deposição final. Nesse processo, mais material é agregado ao fluxo devido à erosão do canal e remobilização de materiais diversos presentes no canal (HUNGR; MCDOUGALL; BOVIS, 2005). Com base em ocorrências de corridas de detritos no Japão, Ikeya (1981) propõe alguns métodos empíricos para o cálculo da magnitude do processo, dentre eles, o chamado volume de arrastamento $\left(V_{a}\right)$ (Equação 4.5), que leva em consideração o comprimento do canal, a largura média e sua profundidade média. Os valores obtidos a partir dessa relação foram comparados com a medição dos volumes e apresentaram boa correlação, demonstrando a viabilidade de sua aplicação, sendo, portanto, utilizado aqui para o cálculo do $V_{a}$ (Figura 4.5).

Equação 4.5: Volume de arrastamento

$$
V_{a}=L s \cdot B \cdot H
$$

Na qual:

$L_{s}:$ é o comprimento do canal $(\mathrm{m})$;

B: é a largura média do canal (m); e

H: é a profundidade média do canal (m).

Figura 4.5: Verificação do volume das corridas de detritos no Japão.

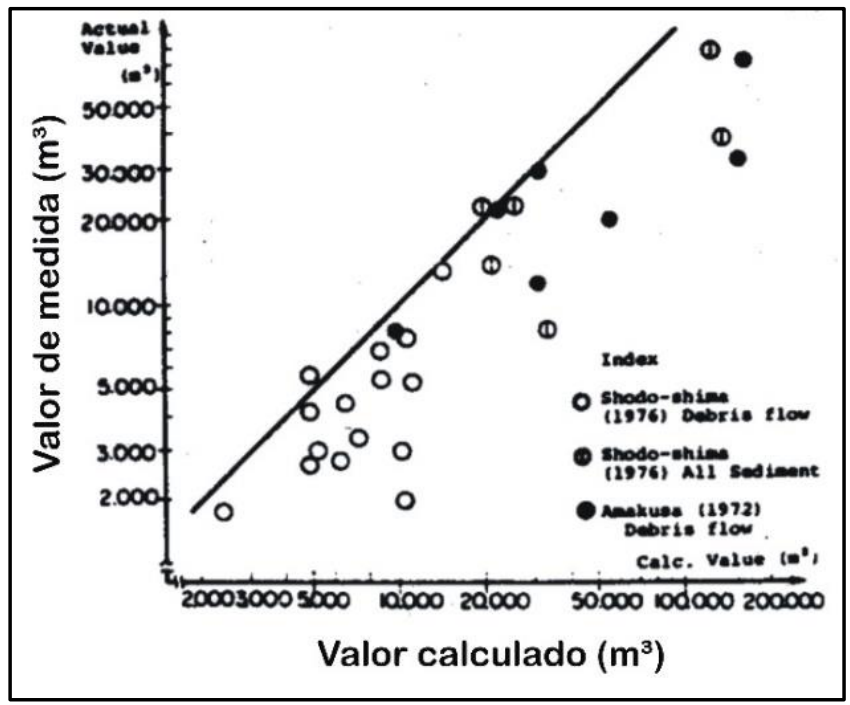

Fonte: modificado de Ikeya (1981). 
Dessa forma, para o cálculo do $V_{a}$, foi calculado o comprimento do canal até o início da deposição, a largura média do canal (média do valor medido em três pontos) (Figura 4.6), e a profundidade média do canal, sendo para este estabelecido o valor médio de 2 metros, com base em observações de campo e nos valores utilizados por Ikeya (1981).

Por fim, o cálculo do volume total $\left(V_{t}\right)$ das corridas de detritos foi feito a partir da soma do volume inicial $\left(V_{i}\right)$ e volume de arrastamento $\left(V_{a}\right)$.

Figura 4.6: Espacialização dos processos e relações consideradas para os cálculos de Volume de iniciação $\left(V_{i}\right)$, Volume de arrastamento $\left(V_{a}\right)$, Volume do depósito final $\left(V_{d p}\right)$ e Volume total $\left(\mathrm{V}_{\mathrm{t}}\right)$ das corridas de detritos.

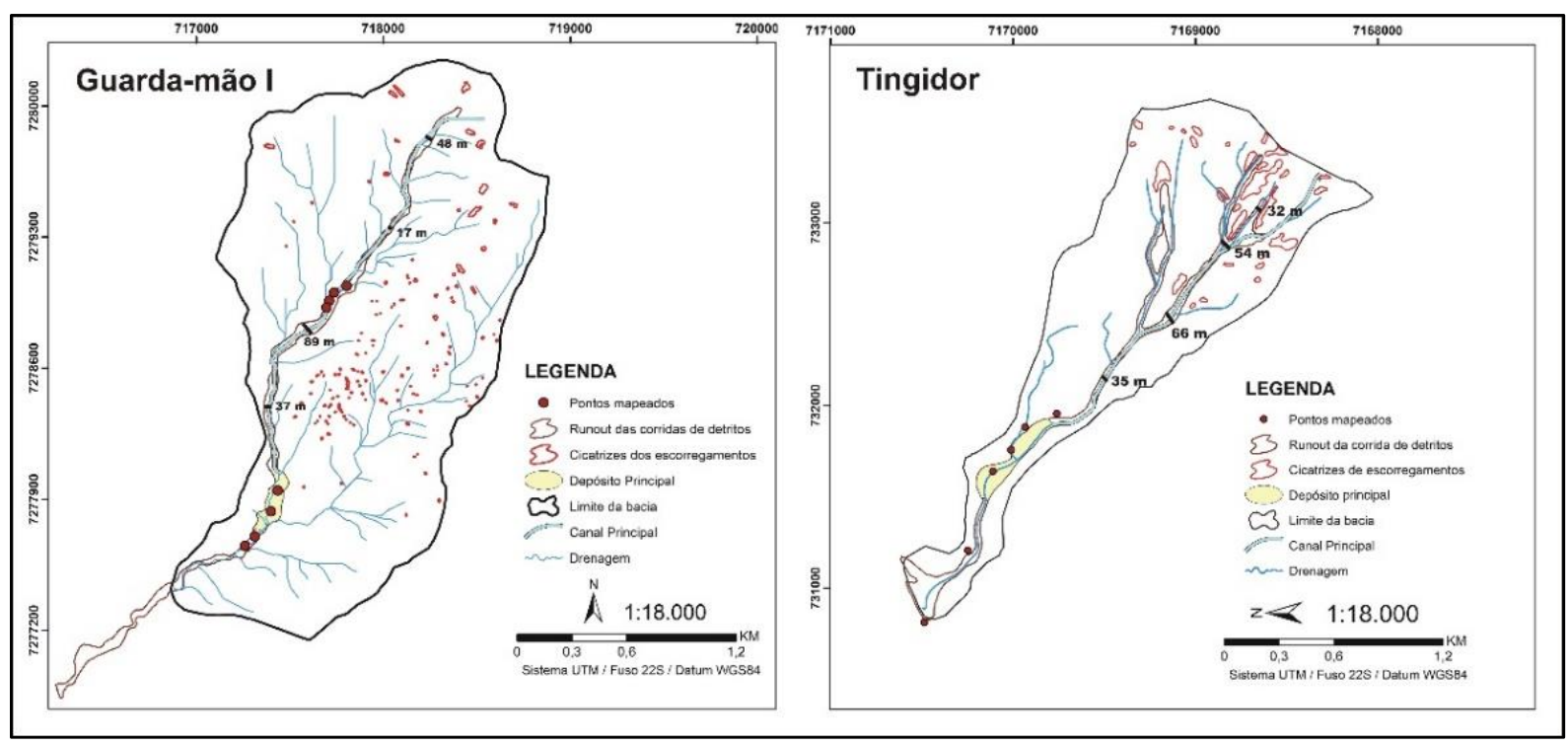

Conforme o exposto, as informações referentes à área das cicatrizes, área dos depósitos e comprimento, largura e profundidade do canal, necessárias para o cálculo final do volume total das corridas de detritos, foram obtidas a partir de observações em campo e medições utilizando os softwares ArcGIS e Excel.

\subsubsection{Características pluviométricas}

A caracterização pluviométrica das áreas estudas foi feita a partir de dados disponíveis de estações meteorológicas próximas às bacias, uma vez que nenhuma das áreas possuía um pluviômetro em sua localidade.

A partir destes dados foram elaborados a distribuição multianual de chuvas para o período de 30 anos, a distribuição mensal de chuva multianual também utilizando dados de 30 anos, e a distribuição mensal de chuva para o ano de 2011 (disponível apenas para a bacia Tingidor). No caso da bacia Tingidor, foram utilizados para elaboração das análises dados 
provenientes de duas estações meteorológicas próximas, a estação Morretes e a estação Colônia Santa Cruz. Já para a bacia Guarda-mão I, foram utilizados dados provenientes da estação meteorológica localizada no centro urbano do município denominada estação Itaoca.

Para verificar as características pluviométricas das bacias referentes ao volume pluviométrico deflagrado em cada área, foram utilizados dados disponibilizados pela NASA da missão Global Precipitation Measurement (GPM), que tem como objetivo a observação da precipitação de chuva e neve em escala global a partir de uma rede de satélites. 


\subsection{Resultados}

\subsubsection{Características das corridas de detritos e dos escorregamentos}

Os resultados do mapeamento do runout das corridas de detritos e das cicatrizes de escorregamentos mostraram que apesar de semelhanças quanto aos fatores deflagradores, as corridas de detritos e os escorregamentos ocorridos nas duas bacias possuem diferenças que podem ter influenciado a magnitude do processo, em especial, a área dos escorregamentos (Figura 4.7). Todos os escorregamentos ocorridos foram classificados como escorregamentos translacionais rasos, de acordo com de Hungr; Leroueil; Picarelli (2014), com a bacia Tingidor apresentando o número total de 29 cicatrizes de escorregamentos, enquanto a bacia Guardamão I apresentou quase 5 vezes mais cicatrizes, 128.

O tamanho das cicatrizes variou consideravelmente, com a área média $\left(\mathrm{m}^{2}\right)$ das cicatrizes sendo $2.111 \mathrm{~m}^{2}$ na bacia Tingidor e apenas $147 \mathrm{~m}^{2}$ na Guarda-mão I. $34 \%$ dos escorregamentos na bacia Tingidor tem uma área maior que $1.500 \mathrm{~m}^{2}$, com um valor máximo de $13.617 \mathrm{~m}^{2}$, e $66 \%$ com área menor que $1.500 \mathrm{~m}^{2}$. Já na Guarda-mão $\mathrm{I}, 100 \%$ dos escorregamentos possuem tamanhos inferiores a $1.500 \mathrm{~m}^{2}$. Apenas $10 \%$ dos escorregamentos na Tingidor possuem área menor do que $500 \mathrm{~m}^{2}$, enquanto na Guarda-mão, $90 \%$ das cicatrizes possuem área abaixo desse valor (Tabela 4.2).

Figura 4.7: Comparação da área dos escorregamentos $\left(\mathrm{m}^{2}\right)(\mathbf{a})$. Predomínio de cicatrizes com área inferior a $1.500 \mathrm{~m}^{2}(\mathbf{b})$.

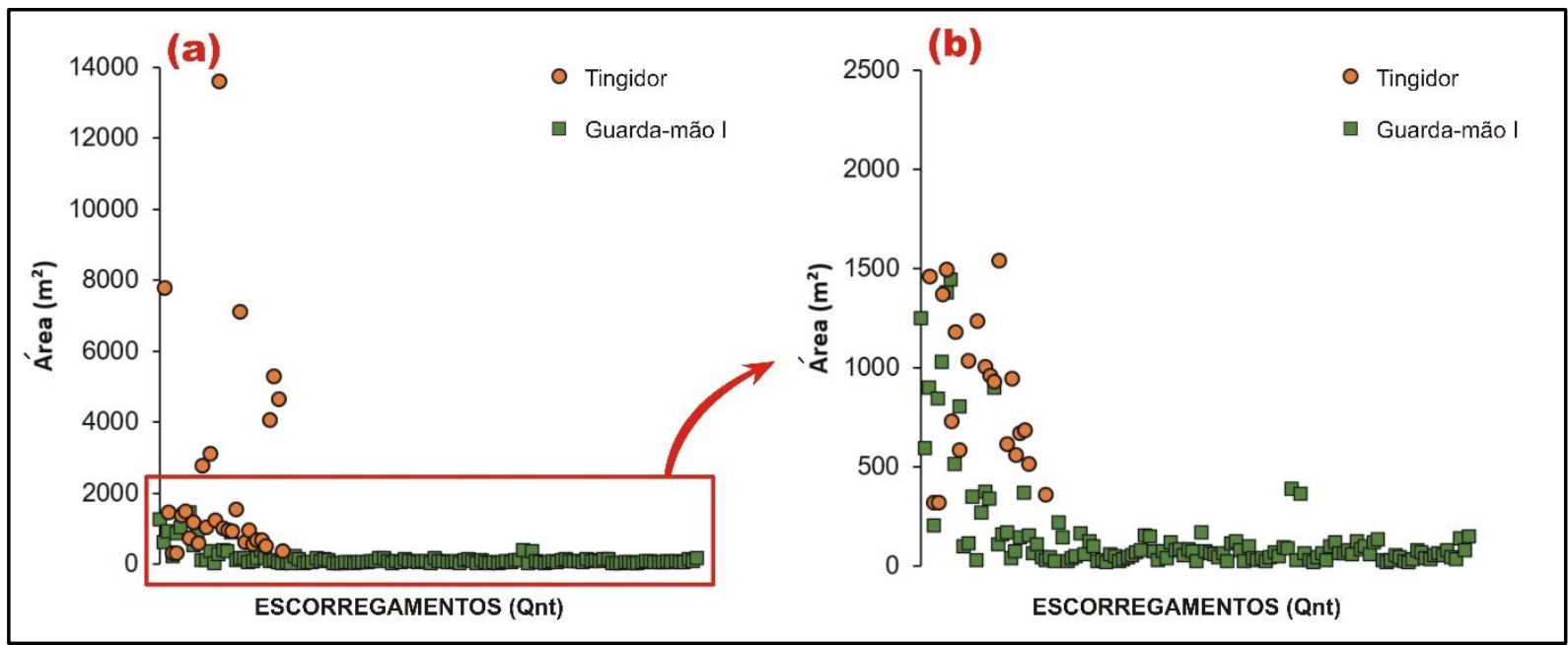


Tabela 4.2: Resultados da área dos escorregamentos.

\begin{tabular}{c|cc} 
ÁREA $\left(\mathbf{M}^{2}\right)$ & TINGIDOR & GUARDA-MÃO I \\
\hline TOTAL & $\mathbf{2 9}$ & $\mathbf{1 2 8}$ \\
\hline QUANTIDADE) & 13,617 & 1,441 \\
\hline MÁXIMO & 317 & 15 \\
MÍNIMO & 2,111 & 147 \\
MÉDIA & $\%$ & $\%$ \\
$<\mathbf{5 0 0}$ & 10 & 92 \\
$\mathbf{- 5 0 0 - 1 . 0 0 0}$ & 35 & 5 \\
$\mathbf{1 . 0 0 0}-\mathbf{1 . 5 0 0}$ & 21 & $\mathbf{\%}$ \\
\hline $\mathbf{1 . 5 0 0}$ & $\mathbf{\%}$ & 0 \\
\hline $\mathbf{1 . 5 0 0}$ & 34 & 100
\end{tabular}

De acordo com o mapeamento realizado, ao menos 9 escorregamentos contribuíram diretamente para a deflagração das corridas de detritos na bacia Tingidor, com uma área total de aproximadamente $44.000 \mathrm{~m}^{2}$ (Figura 4.8a e b). Em comparação, apenas 1 escorregamento contribuiu diretamente para a corrida de detritos na bacia Guarda-mão I, com uma área total de $1.247 \mathrm{~m}^{2}$ (Figura 4.9a e b).

As corridas de detritos na Tingidor foram iniciadas por pelo menos 3 pulsos distintos a partir de escorregamentos na parte superior da bacia, convergindo para o canal principal. A zona de iniciação possui amplitude altimétrica de $300 \mathrm{~m}$, seguida pela zona de transporte, que possui a maior amplitude, com $380 \mathrm{~m}$ e comprimento de $1.521,20$, e a zona de deposição, com a menor amplitude, $144 \mathrm{~m}$, e $1.374 \mathrm{~m}$ de comprimento (Figura 4.8b).

Na bacia Guarda-mão I, as corridas de detritos foram deflagradas a partir de um único escorregamento, dando origem a um único pulso no canal principal da bacia. A zona de iniciação possui amplitude altimétrica de $222 \mathrm{~m}$, seguida de amplitude altimétrica de $500 \mathrm{~m}$ e comprimento de $2.364 \mathrm{~m}$ da zona de transporte, e apenas $55 \mathrm{~m}$ de amplitude e $922 \mathrm{~m}$ de comprimento na zona de deposição (Figura 4.9b).

Estes resultados indicam que a bacia Guarda-mão I possui um comprimento de "runout" na zona de transporte $800 \mathrm{~m}$ mais longo do que a Tingidor, além de uma maior amplitude altimétrica com mais de $100 \mathrm{~m}$ de diferença. Tais resultados indicam um maior potencial de arrastamento e erosão na Guarda-mão I em comparação à Tingidor, o que poderia contribuir para um maior volume da corrida de detritos a partir do arrastamento. 
Figura 4.8: Inventário dos escorregamentos e seções mapeadas (a) e "Runout" da corrida de detritos (b) na bacia Tingidor.

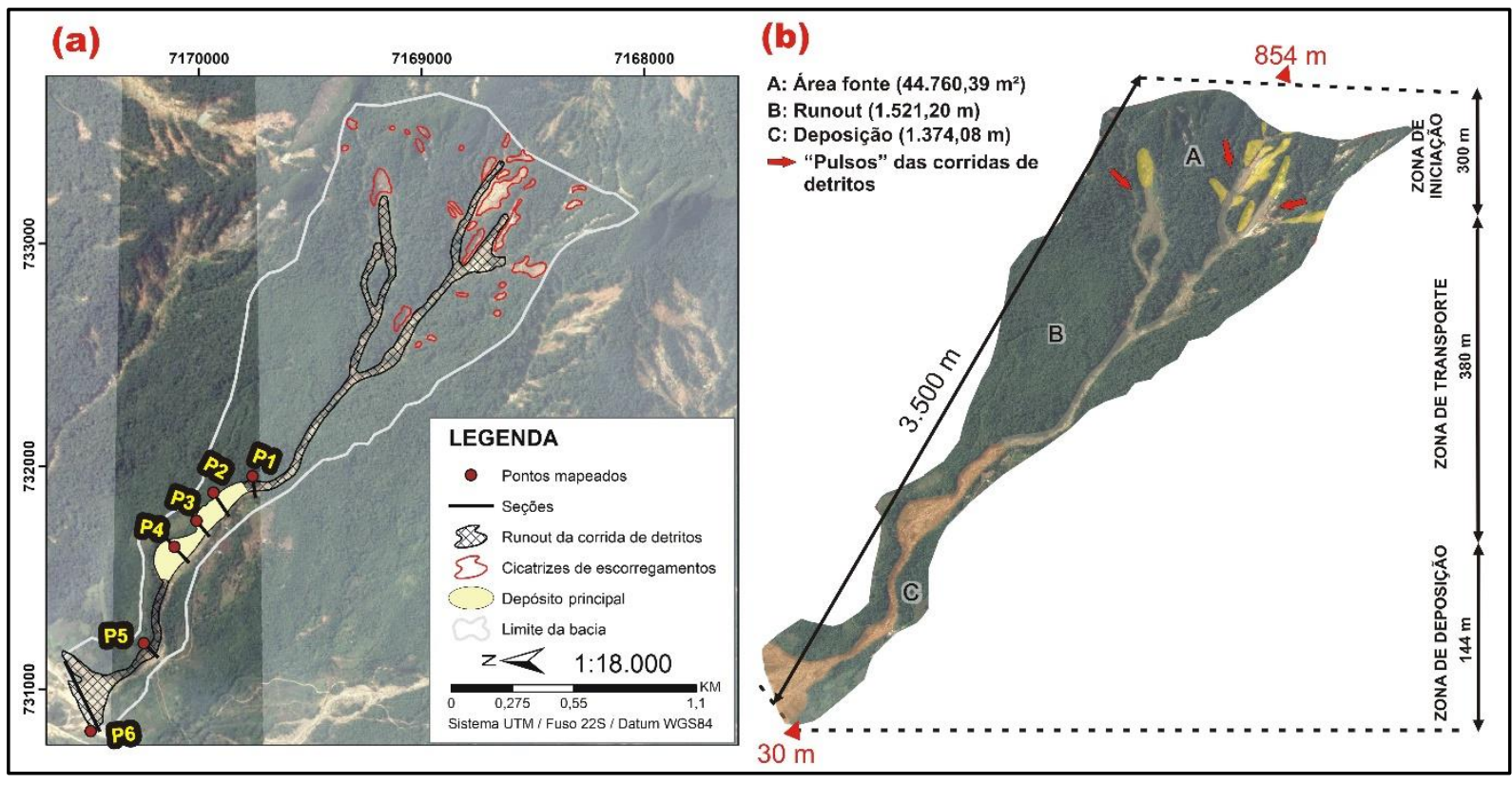

Fonte: Google Earth, 16 de setembro de 2012, com 2,5 m de resolução.

Figura 4.9: Inventário dos escorregamentos e seções mapeadas (a) e "Runout" da corrida de detritos (b) na bacia Guarda-mão.

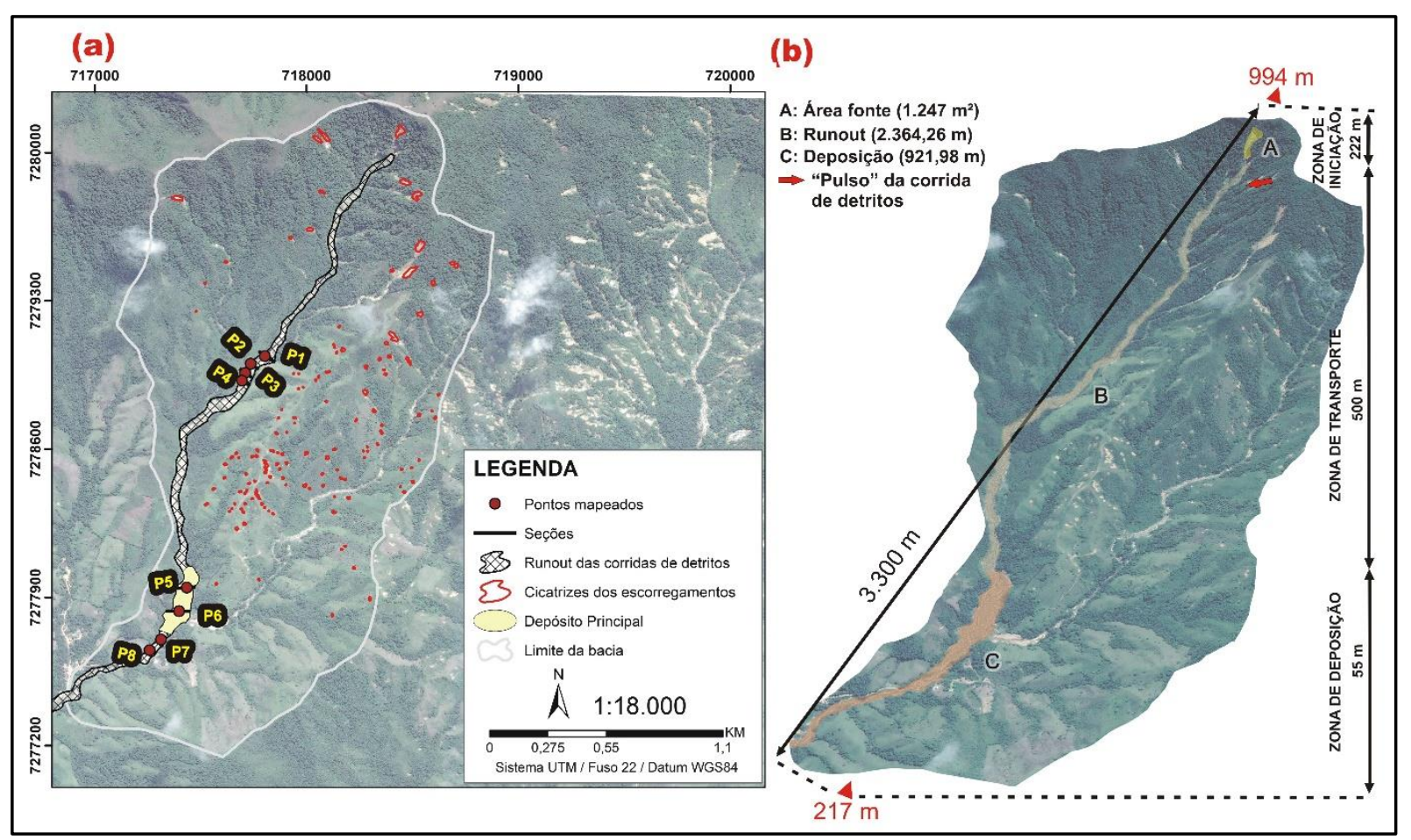

Fonte: Google Earth, 8 de outubro de 2014, com 2,5 m de resolução. 


\subsubsection{Análise da morfologia dos depósitos}

As características dos depósitos presentes ao longo do caminho percorrido pelas corridas de detritos demonstram as particularidades do processo no decorrer de sua ocorrência. Foram identificadas feições que corroboram tratar-se de um processo de movimento de massa do tipo corridas de detritos, tais como inversão granulométrica e presença de "levees", ou ondas laterais (COSTA, 1984; HUNGR et al., 2016; JAKOB, 2005a), encontradas em ocorrências em diversas partes do mundo, como Canadá, China e Colômbia (GARCÍA-DELGADO; MACHUCA; MEDINA, 2019; KEAN et al., 2019).

Ao todo foram mapeados 14 pontos, 8 na bacia Guarda-mão I e 6 na bacia Tingidor, seguindo o curso do canal principal onde o fluxo se desenvolveu, de montante à jusante, sendo, portanto, denominado P1 o mais próximo à zona de iniciação do processo, em direção às porções mais planas e de deposição. Ambos os processos foram iniciados devido ao aporte de material proveniente dos escorregamentos deflagrados nas encostas, sendo este um dos fatores deflagradores de corridas de detritos mais comum em ambiente tropical.

As corridas de detritos deflagradas na bacia Tingidor se caracterizam por terem se iniciado a partir do aporte de sedimentos e de materiais provenientes de escorregamentos ocorridos nas porções mais elevadas da bacia. O fluxo se iniciou, a partir de três escorregamentos, dando origem a pelo menos três pulsos, gerando duas frentes que confluem em apenas um fluxo no canal principal à jusante (Figura 4.10). Apesar de possuir mais tempo decorrido desde a ocorrência das corridas de detritos, a bacia ainda apresenta depósitos bem preservados, inclusive com matéria orgânica. Com base nas características dos depósitos encontrados e na imagem de satélite, foi possível estabelecer que a deposição principal da corrida de detritos ocorreu entre os pontos $\mathrm{P} 2-\mathrm{P} 4$, onde há a saída do vale e alargamento do vale em $\mathrm{V}$, o que pode ter contribuído para o espraiamento do fluxo outrora canalizado na planície (Figura 4.11). Os pontos P5 e P6 correspondem a deposição posterior, localizados próximo a desembocadura do rio Tingidor. O fluxo proveniente da sub-bacia Tingidor desemboca na bacia Jacareí, agregando mais material à corrida de detritos já em curso no canal principal em direção à jusante, deflagrada em outra sub-bacia. 
Figura 4.10: Panorama geral das corridas de detritos e feições encontradas nos depósitos na bacia Tingidor.

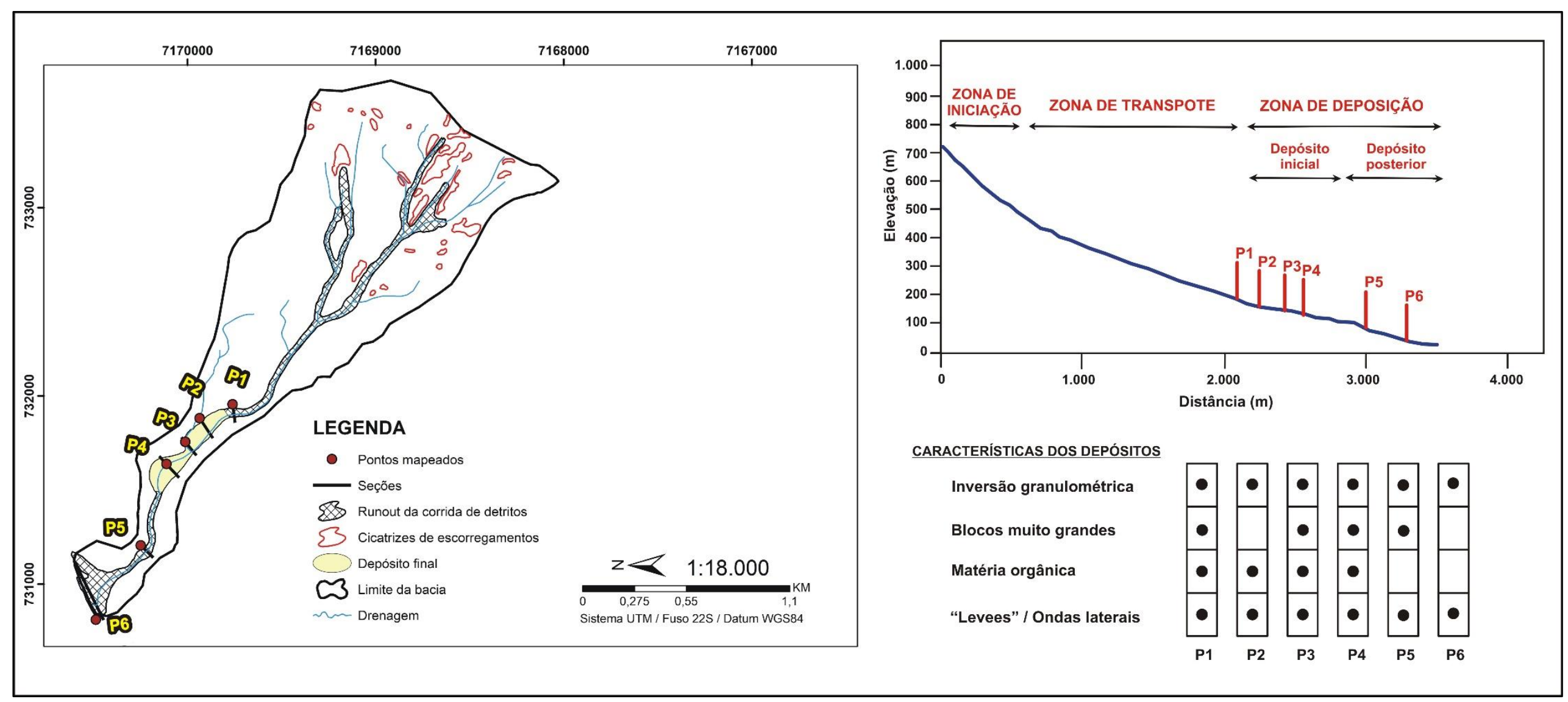


Figura 4.11: Visão geral dos depósitos das corridas de detritos mapeados na bacia Tingidor (a). Destaque para a deposição principal da corrida $(\mathbf{b})$.

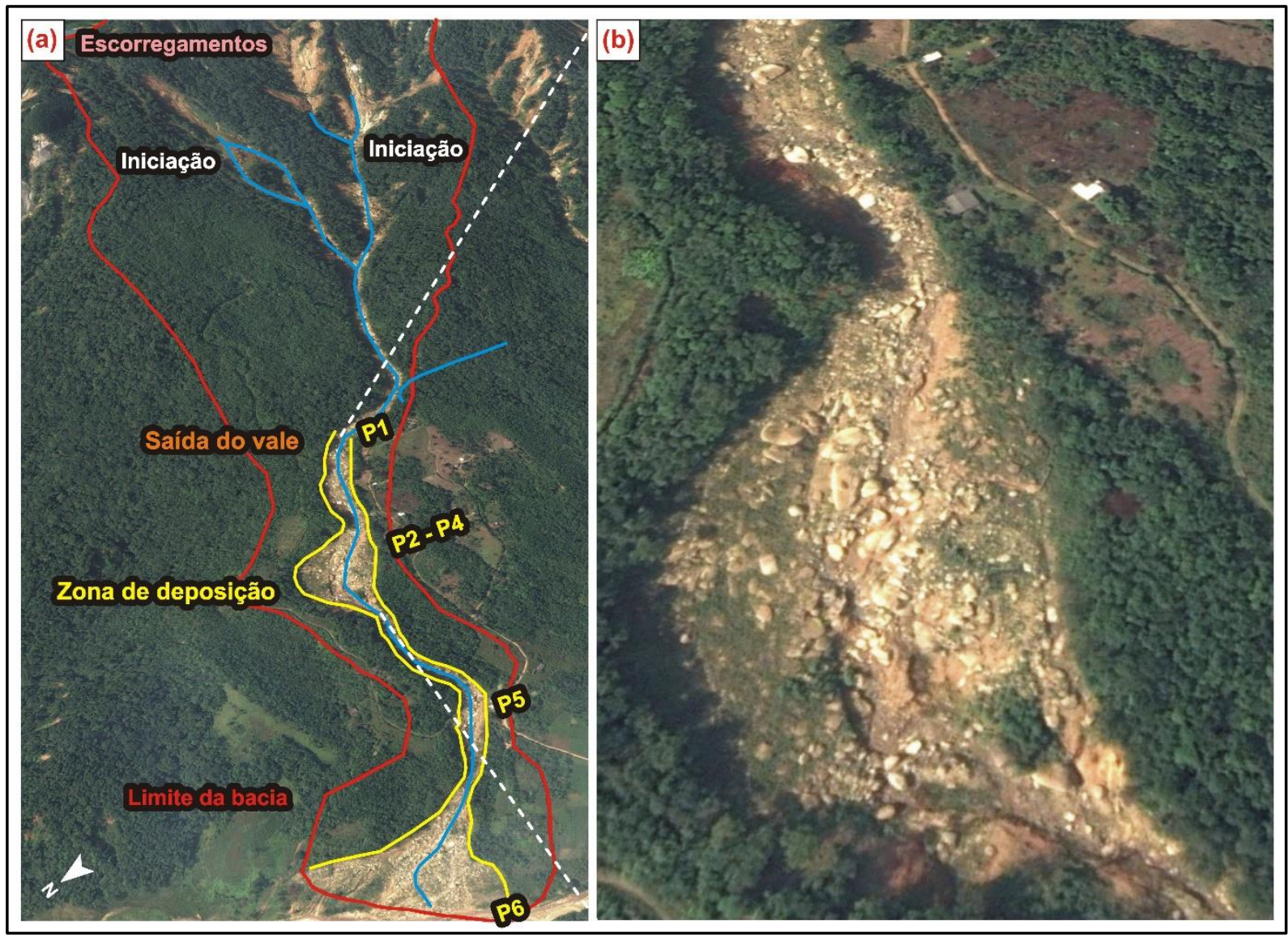

Fonte: Google Earth, 16 de setembro de 2012, resolução de 2,5 m.

O P1 possui localização mais próxima à área de iniciação do processo, sendo possível a identificação de todas as feições na área, inclusive aquelas mais prováveis de serem encontradas em áreas planas, mais propensas à deposição de materiais mais grosseiros, como grandes blocos (Figura 4.12), além de matéria orgânica entre alguns blocos, como troncos de árvores (Figura 4.13). Neste ponto não há o espraiamento dos blocos em uma "área de deposição", uma vez que se trata de uma área onde o canal/talvegue é mais estreito. Os depósitos formados às margens do rio são do tipo levees", estabelecidos durante a passagem do fluxo. 
Figura 4.12: Feições encontradas no $P 1$ da bacia Tingidor, na margem direita do canal.

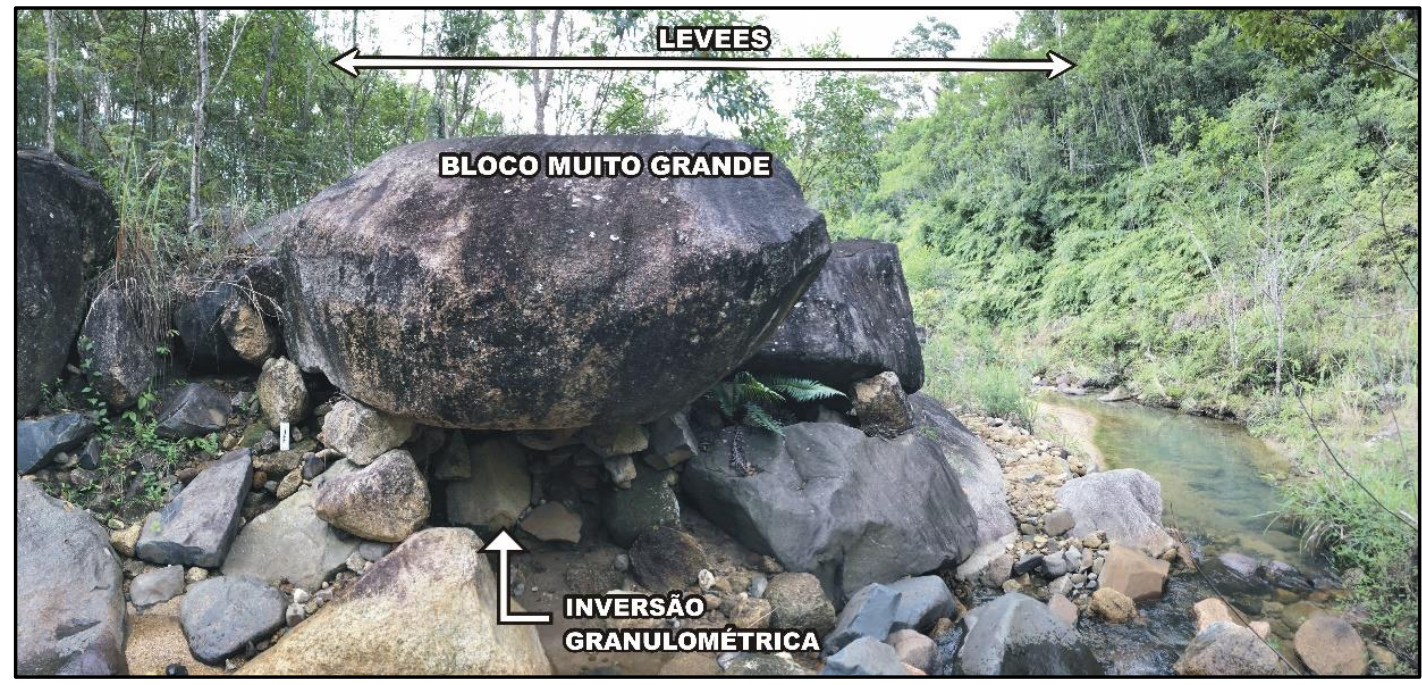

Figura 4.13: Feições encontradas no P1 da bacia Tingidor, na margem esquerda do canal.

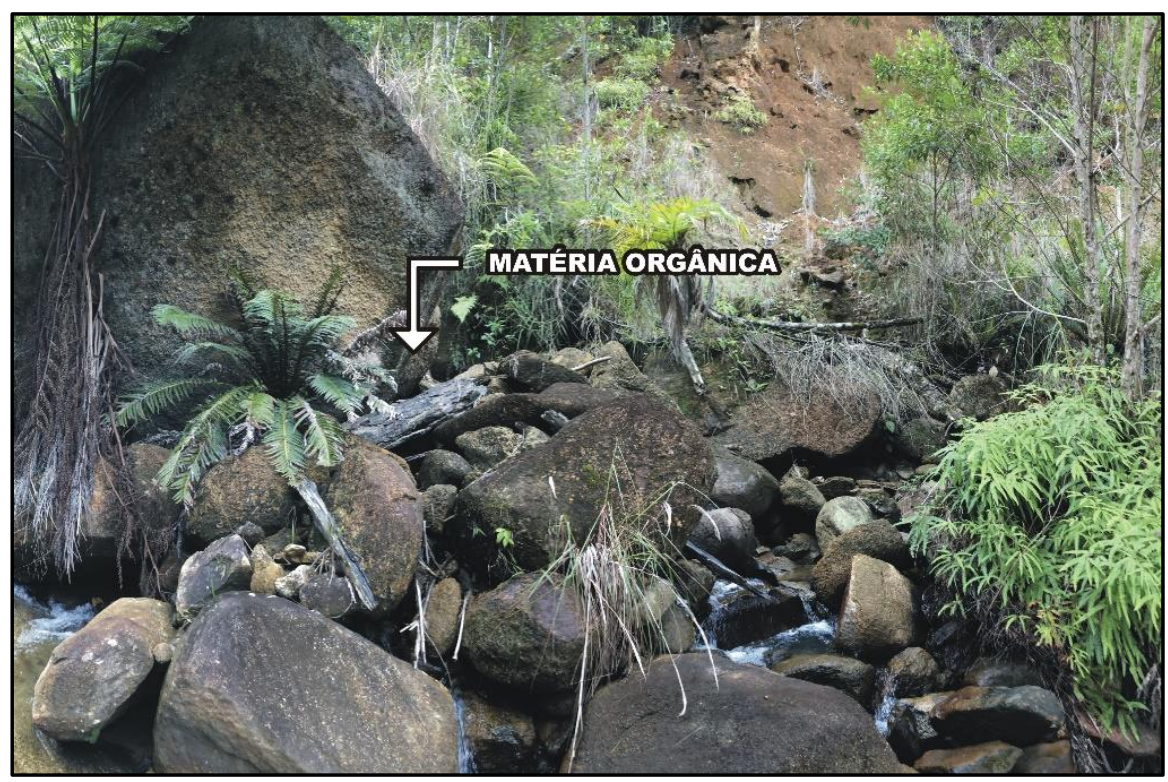

Os pontos P2, P3 e P4 compõe a denominada "deposição principal", onde ocorreu o espraiamento do fluxo. A intensidade do fluxo provocou forte erosão das margens do rio, com a deposição de blocos muito grandes com mais de 2 metros de diâmetro. Foram identificadas todas as feições, com destaque para os pontos P3 e P4, com todas as feições presentes. Em ambas as margens do rio, verificou-se depósitos do tipo "levees", além da presença de troncos entremeados aos blocos de tamanhos variados, com inversão granulométrica (Figura 4.14). 
Figura 4.14: Feições encontradas no $\mathrm{P} 2$ da bacia Tingidor, na margem direita do canal.

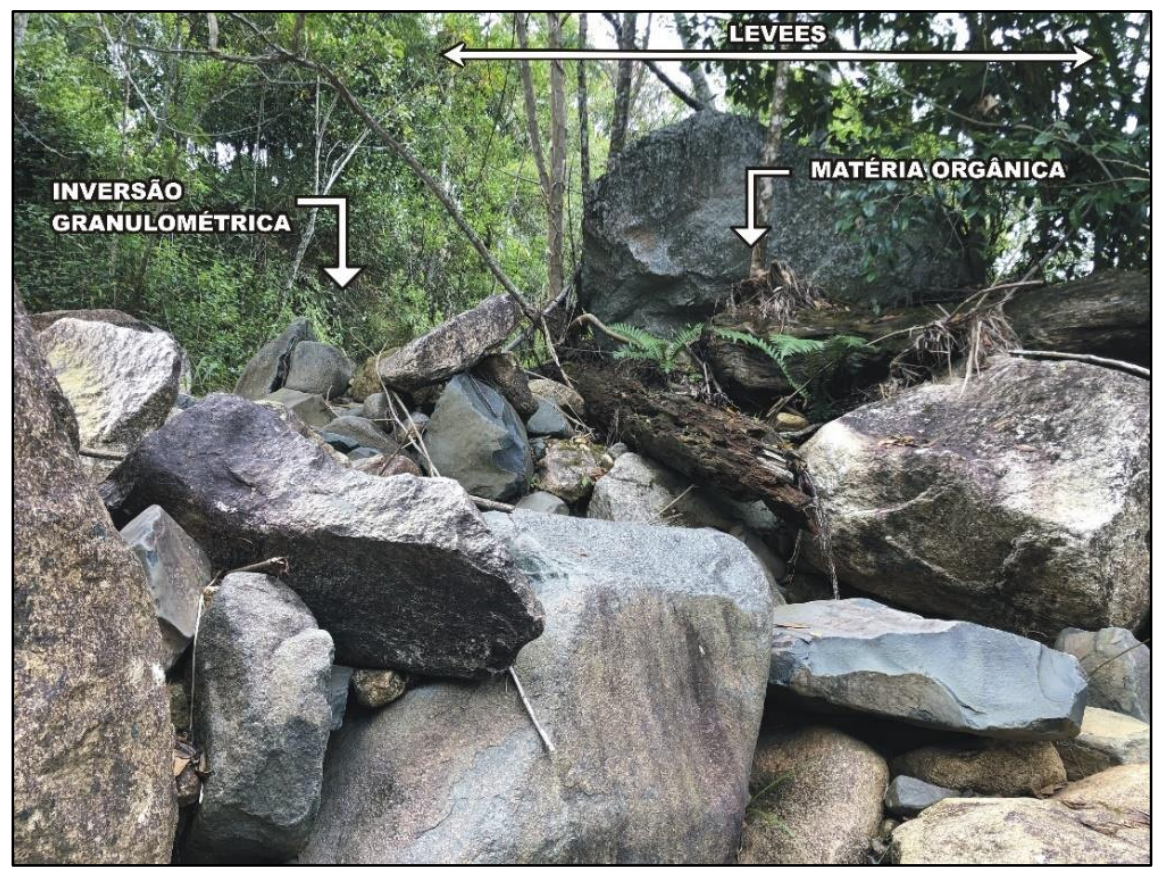

Os pontos P3 e P4 apresentam, além das feições descritas anteriormente, blocos de tamanho muito grande (> 2 metros de diâmetro), que se destacam na paisagem e possuem elevado poder destrutivo (Figuras 4.15 e 4.16).

Figura 4.15: Feições encontradas no $\mathrm{P} 3$ da bacia Tingidor.

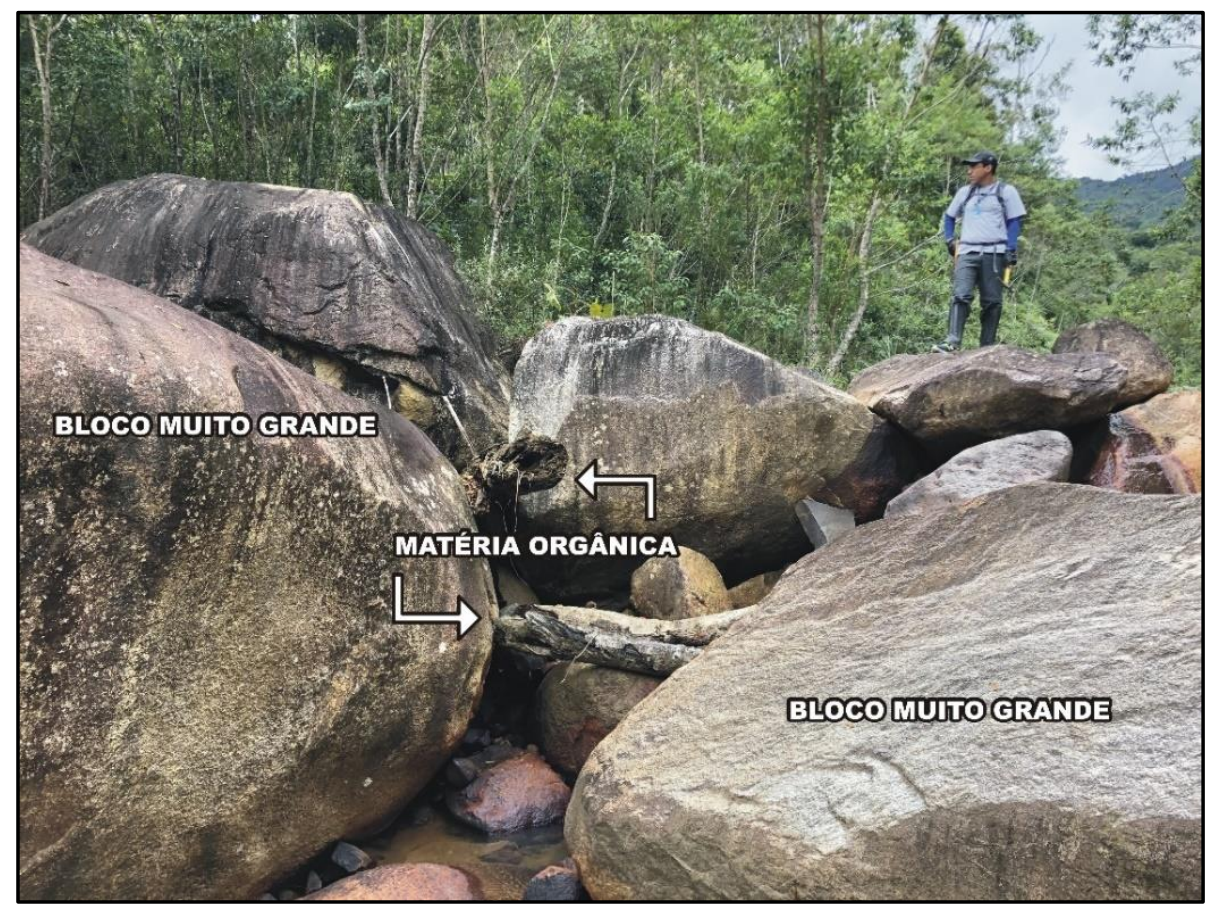


Figura 4.16: Feições encontradas no $\mathrm{P} 3$ da bacia Tingidor, na margem esquerda do canal.

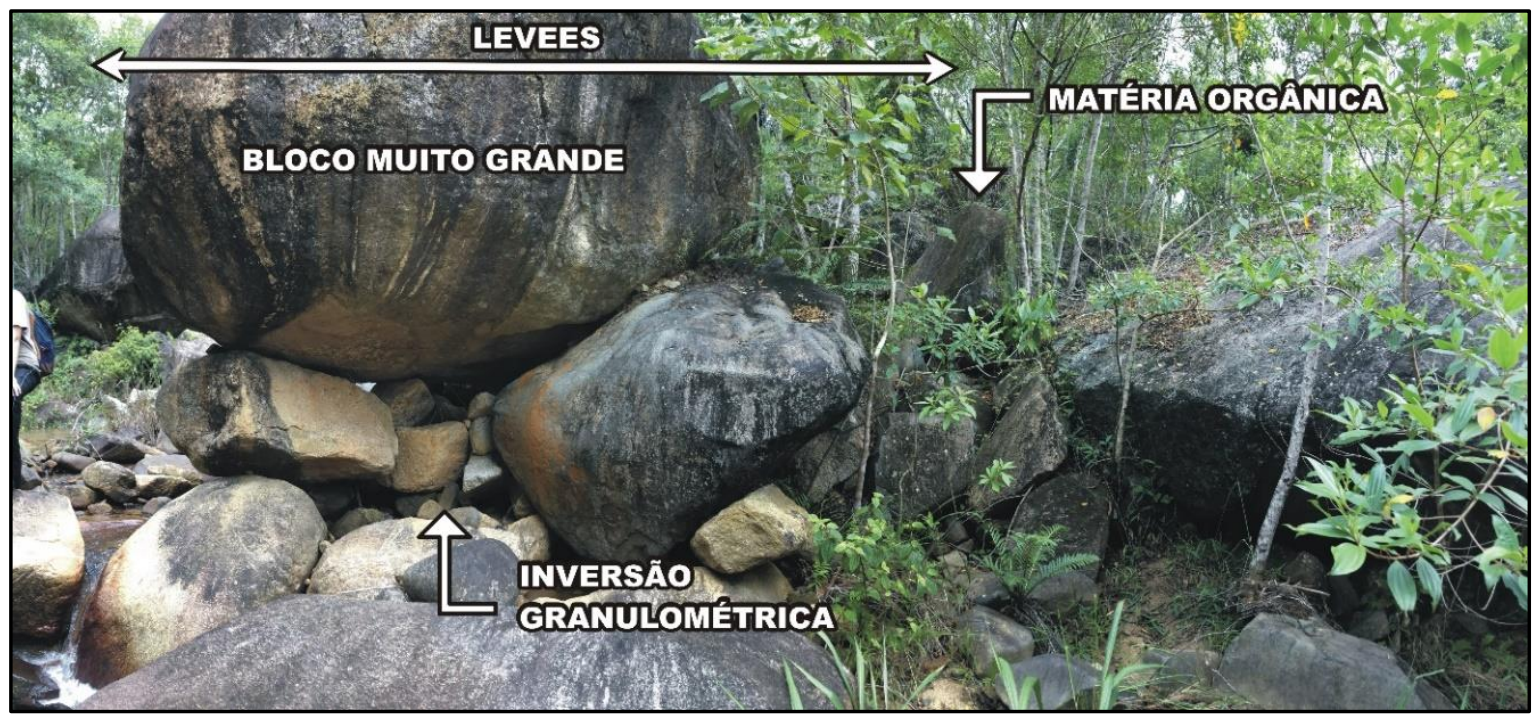

Outra característica importante verificada foi a presença de sedimentos finos sobre os blocos, indicando a altura da água durante o evento (Figura 4.17).

Figura 4.17: Feições encontradas no P4 da bacia Tingidor, na margem direita do canal.

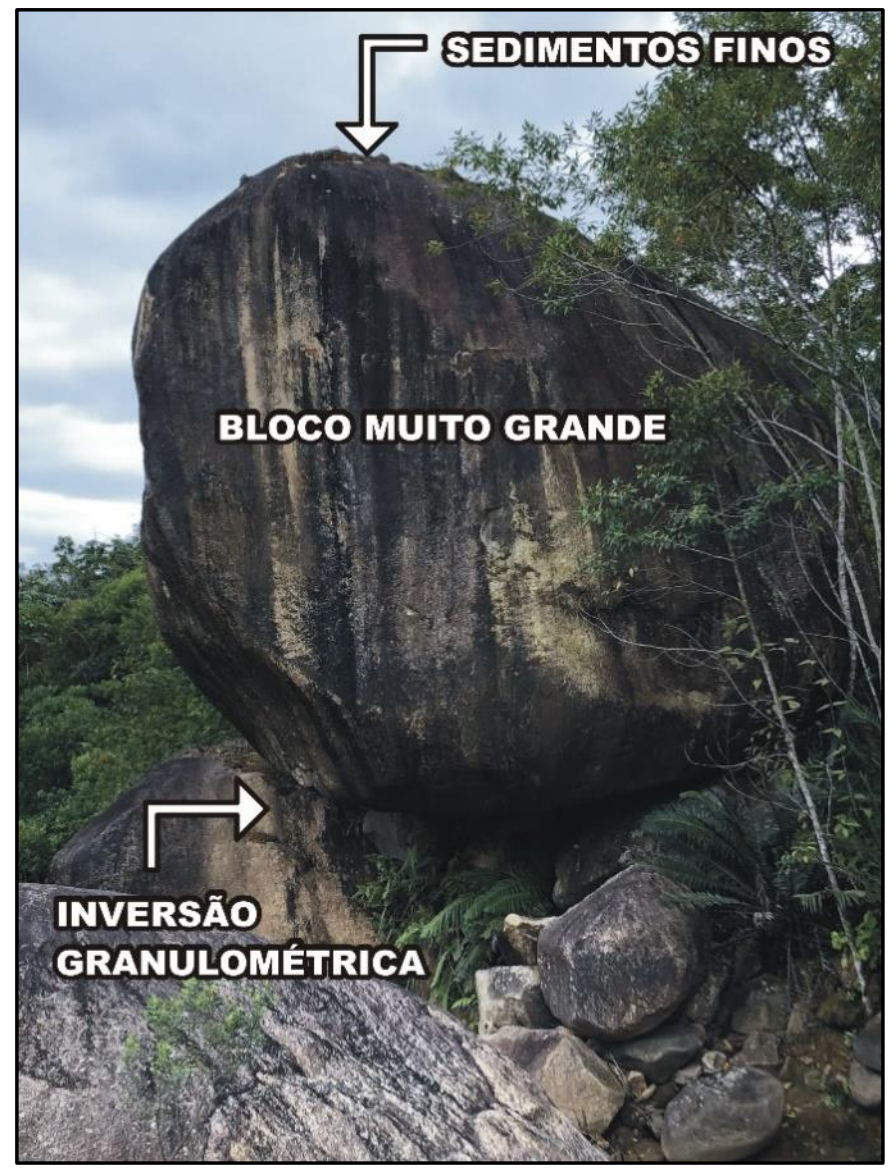


O ponto P5 não faz parte do depósito delimitado como principal, dada as características do relevo, ou seja, vale mais fechado e sem uma área de "abertura" para intensa deposição, todavia, apresenta depósitos expressivos, com blocos muito grandes, inversão granulométrica e "levees" (Figura 4.18). A área apresenta intensa erosão das margens do rio, o que contribuiu para a destruição de parte de uma piscina em uma moradia na margem esquerda do rio, apesar desta encontrar-se em área elevada em comparação com o nível do rio atualmente, indicando a altura e potencial destrutivo do fluxo durante a sua passagem (Figura 4.19).

Figura 4.18: Feições encontradas no $\mathrm{P} 5$ da Bacia Tingidor, em ambas as margens.

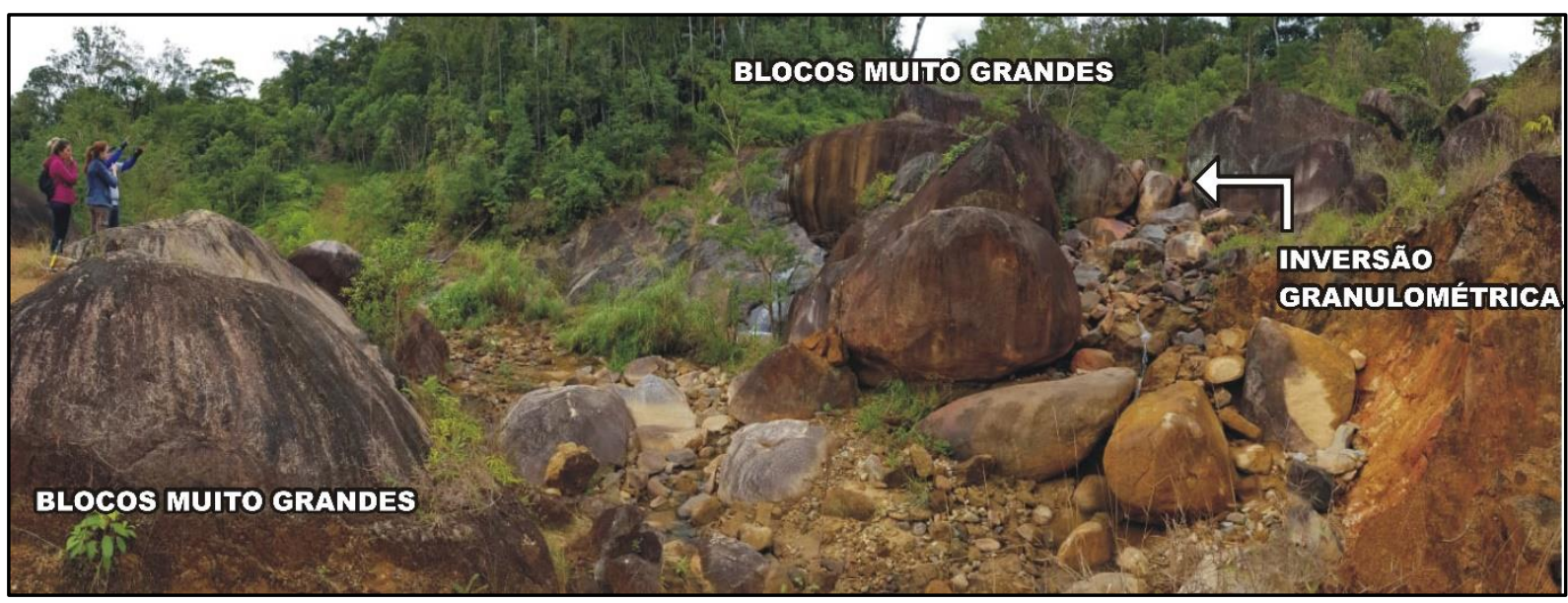

Figura 4.19: Piscina parcialmente destruída em moradia localizada no alto da encosta, na margem esquerda do rio, no P5. (a): imagem de 2011, logo após o evento, com sedimentos finos ainda presentes, indicando a altura do fluxo. (b): imagem recente da mesma área, já sem sedimentos finos e com canal e vale mais profundo, em comparação à época do evento.

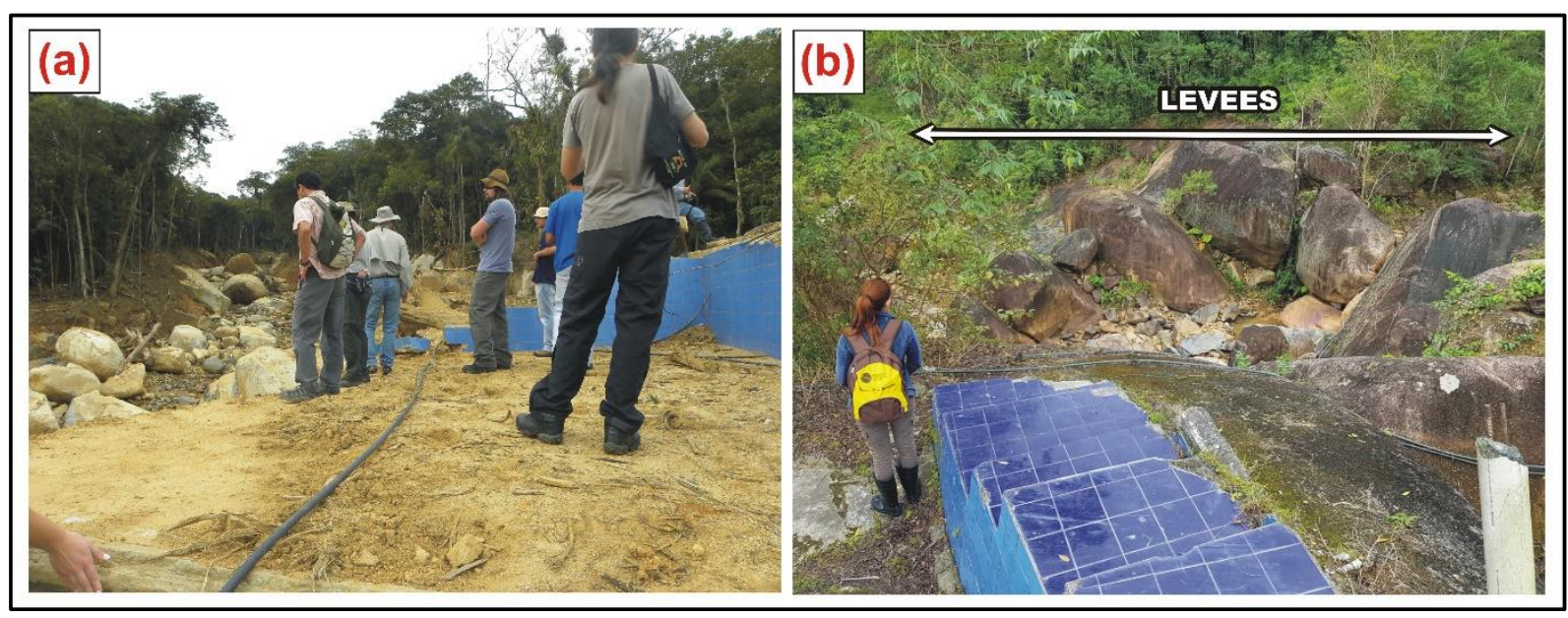

Fonte: GPmorfo (2011) (a). 
O ponto $\mathbf{P 6}$ está localizado em área mais planas do relevo, onde o rio Tingidor, desagua no rio Jacareí, estando no limite da delimitação da bacia. Os depósitos se diferenciam dos anteriores por não apresentarem feições grosserias, como a presença de blocos muito grandes, e se caracterizam pela presença de sedimentos de menor granulometria e matéria orgânica em abundância (Figura 4.20). Tais características se devem à dinâmica do processo de corridas de detritos, uma vez que nos pontos anteriores ocorreu a deposição dos blocos mais grosseiros, que tendem a perder força de "escoamento" conforme o ângulo do relevo diminui, geralmente, a partir de números menores de $10^{\circ}$ (COSTA, 1984; VANDINE, 1996). O fluxo ainda manteve força após esta deposição, mas com capacidade de transporte apenas do material mais fino, atingindo áreas ainda menos declivosas e agregando mais material ao fluxo principal (Figura 4.21).

Figura 4.20: Feições encontradas no P6 da Bacia Tingidor, na margem direita.

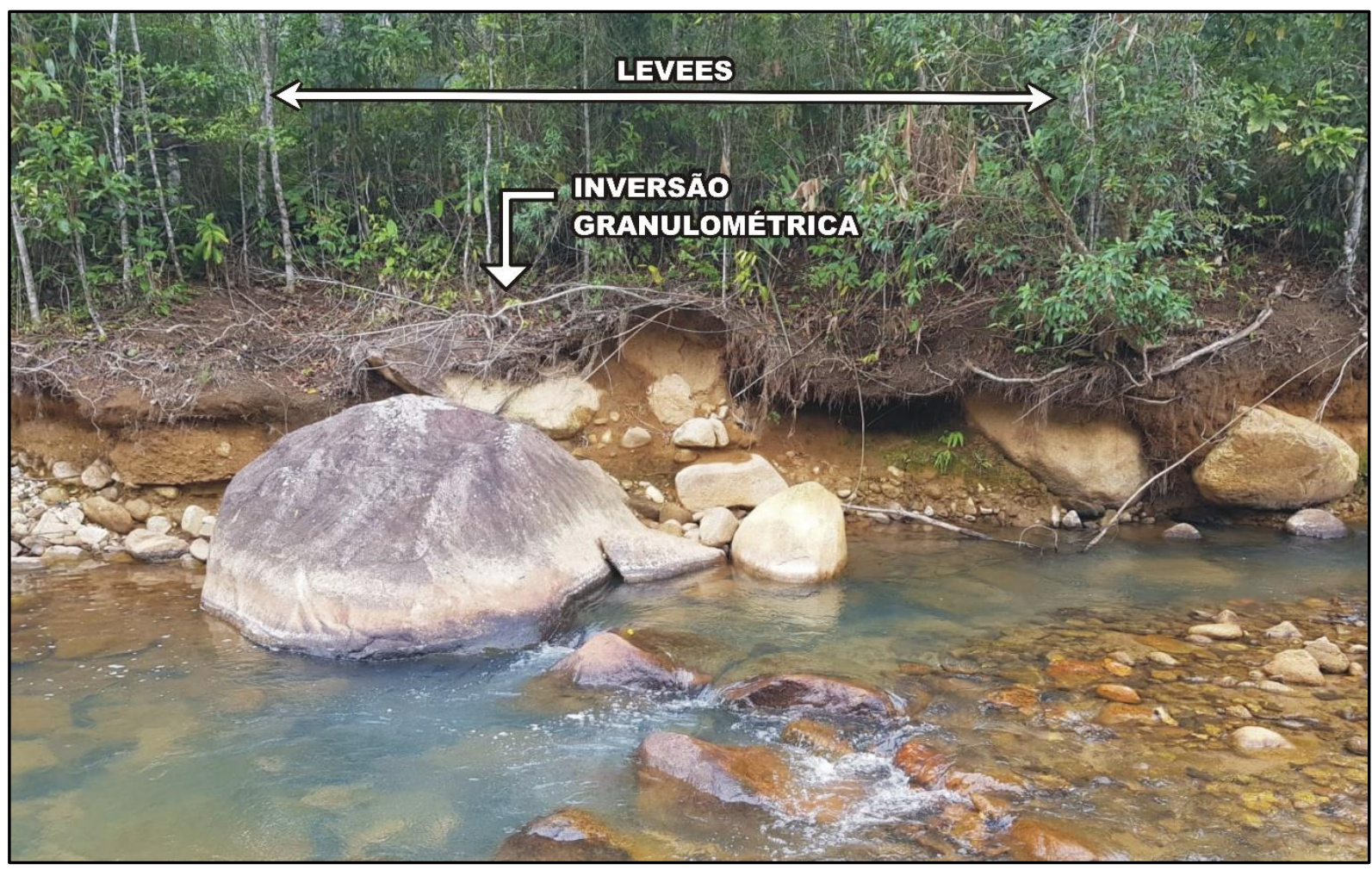


Figura 4.21: Moradia parcialmente destruída pela corrida de detritos na bacia Jacareí, com destaque em vermelho para a altura do fluxo. (a): imagem atual (2019). (b): registro de 2011.

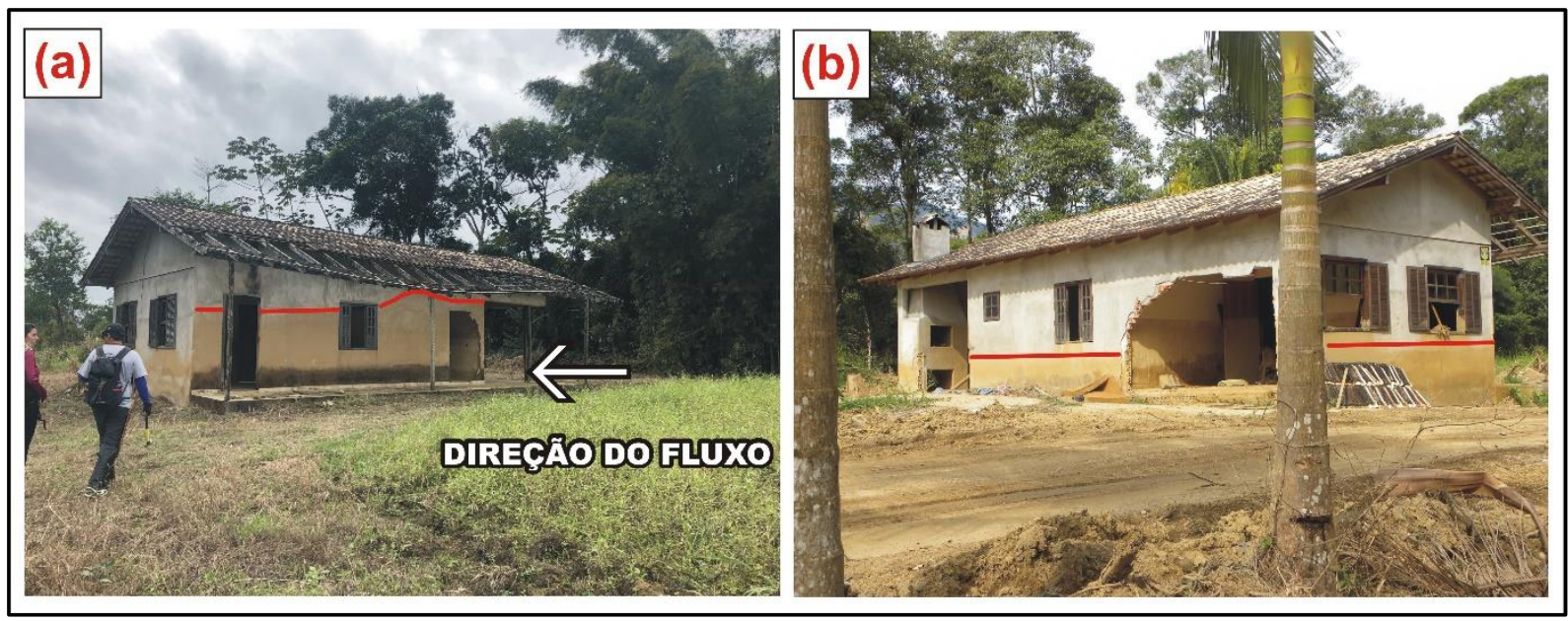

Fonte: GPmorfo (2011) (b).

Assim como na bacia Tingidor, as corridas de detritos na bacia Guarda-mão I, em Itaoca, se iniciaram a partir da deflagração de escorregamentos nas porções mais altas do relevo. O fluxo principal (rio Guarda-mão), recebeu contribuição de canais menores (tributários) em dois pontos, próximo ao P1, e na área de deposição principal, próximo ao P6 (Figura 4.22).

Apesar de ainda estarem visíveis na paisagem, a regeneração da vegetação foi muito intensa, cobrindo, em poucos anos, os depósitos das corridas de detritos de 2014. A identificação e o mapeamento dos depósitos em meados de julho de 2019 foram favorecidos pela ação de alguns agricultores, que pretendem estabelecer na área o plantio de Pinos, e por isso atearam fogo na vegetação que havia se desenvolvido, revelando os depósitos outrora ocultos.

Os depósitos P1 a P4 estão localizados mais próximos a área de iniciação do processo, em área de difícil acesso, que, no entanto, foi facilitada devido à abertura de estradas ao longo da bacia para o plantio de Pinos. Já os depósitos P5 e P6 compõe a denominada deposição principal, onde a maior parte dos materiais grosseiros, como grandes blocos, foi depositado devido à diminuição do ângulo e alargamento do vale em direção à planície. Os depósitos $\mathbf{P 8}$ e P7 se localizam após a deposição principal, concentrando materiais menos grosseiros e compostos por maior conteúdo de orgânica, que seguiu até o Rio Palmital, atingindo o centro urbano do município (Figura 4.23). 
Figura 4.22: Panorama geral das corridas de detritos e feições encontradas nos depósitos na bacia Guarda-mão I.

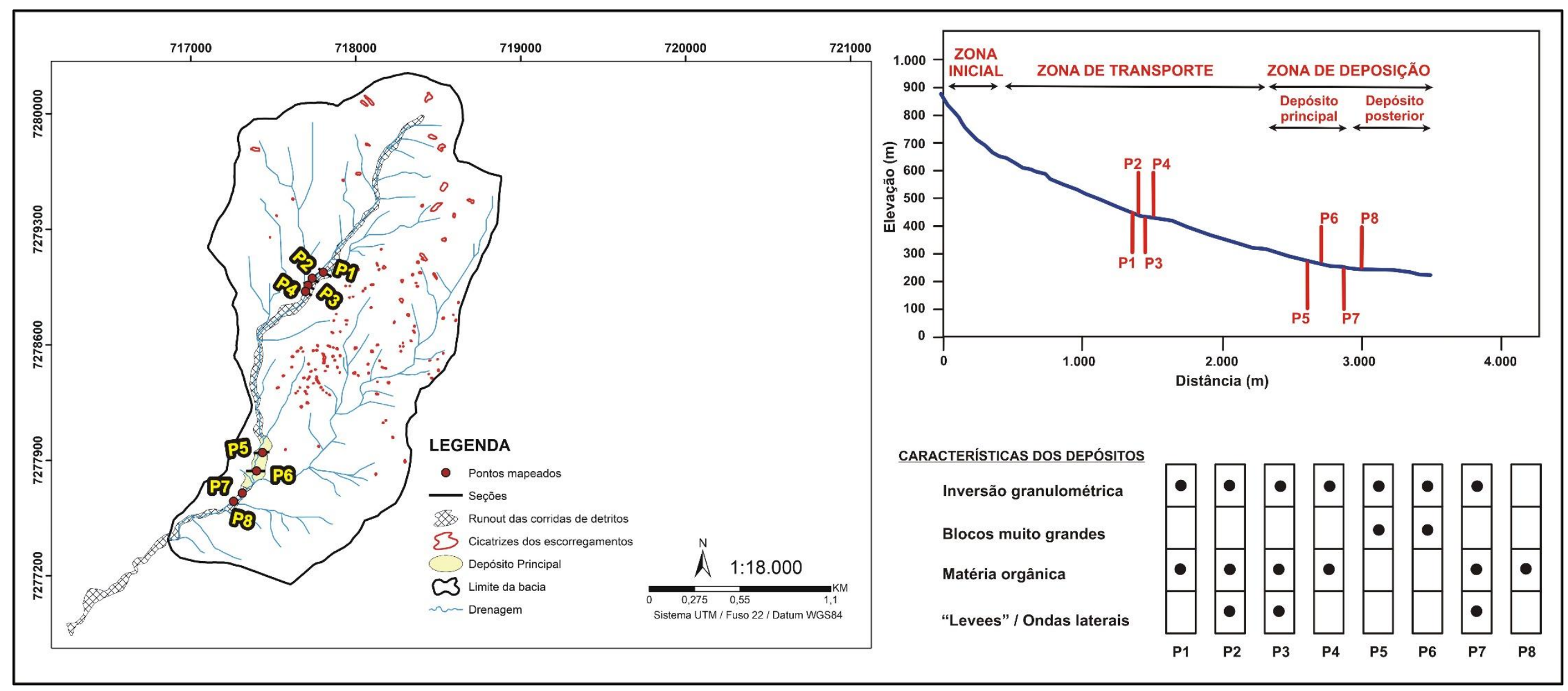


Figura 4.23: Visão geral dos depósitos de corridas de detritos mapeados na bacia Guarda-mão I (a). Vista aérea da área de deposição principal (b); Visão horizontal da área de deposição principal (c).

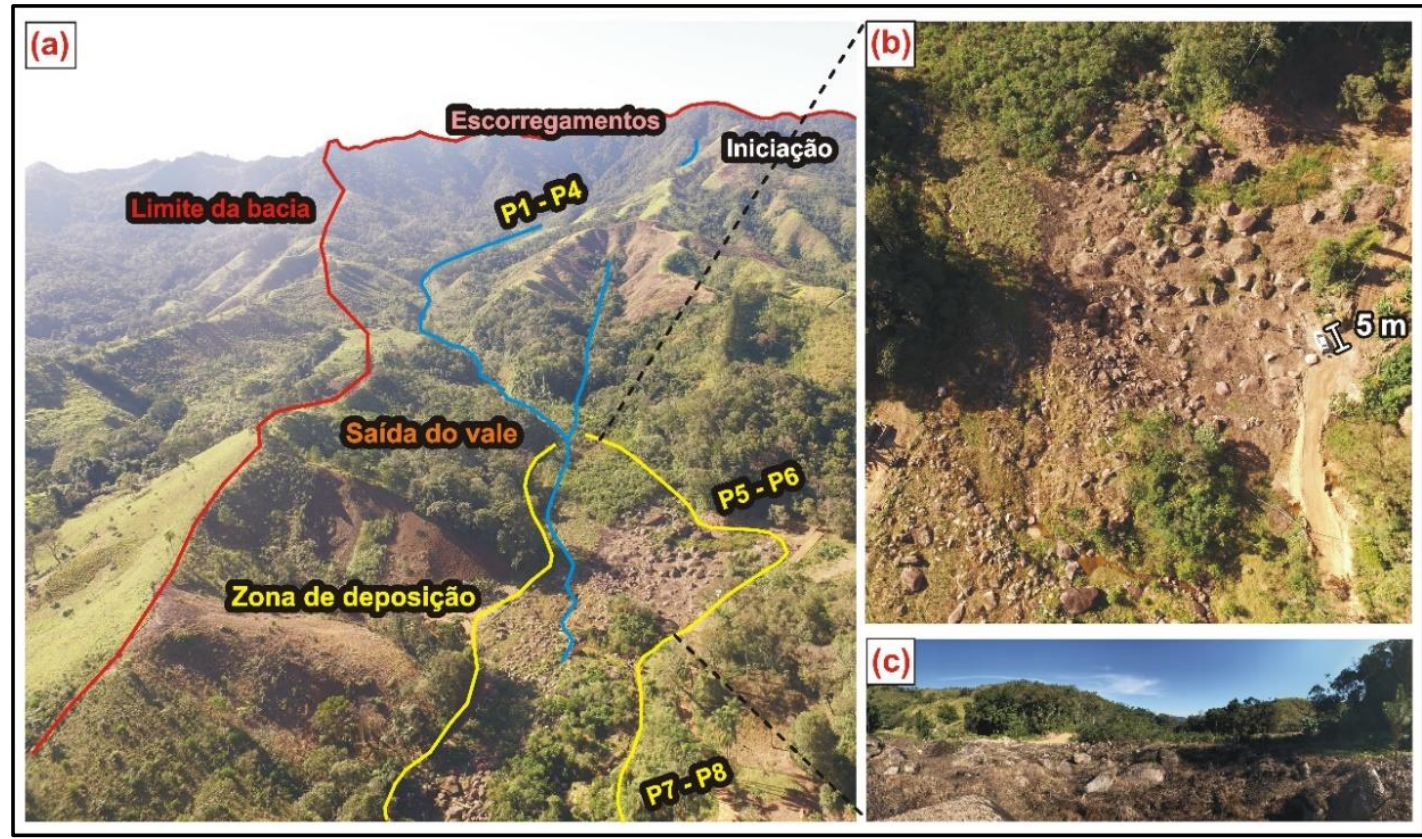

Fonte: imagens de drone cedidas por M. F. Gramani (2019) (a e b).

Os depósitos P1-P4 estão localizados mais próximos a iniciação das corridas de detritos, em vale em formato $\mathrm{V}$ com aproximadamente 3,0 metros de profundidade e 30 metros de largura; há a presença de barramentos naturais, compostos majoritariamente por blocos (Figura 4.24), e "ilhas de deposição" (Figura 4.25) em área de confluência de canais.

Figura 4.24:Feições encontradas no P1 da Bacia Guarda-mão I, com destaque para o barramento natural formado no canal.

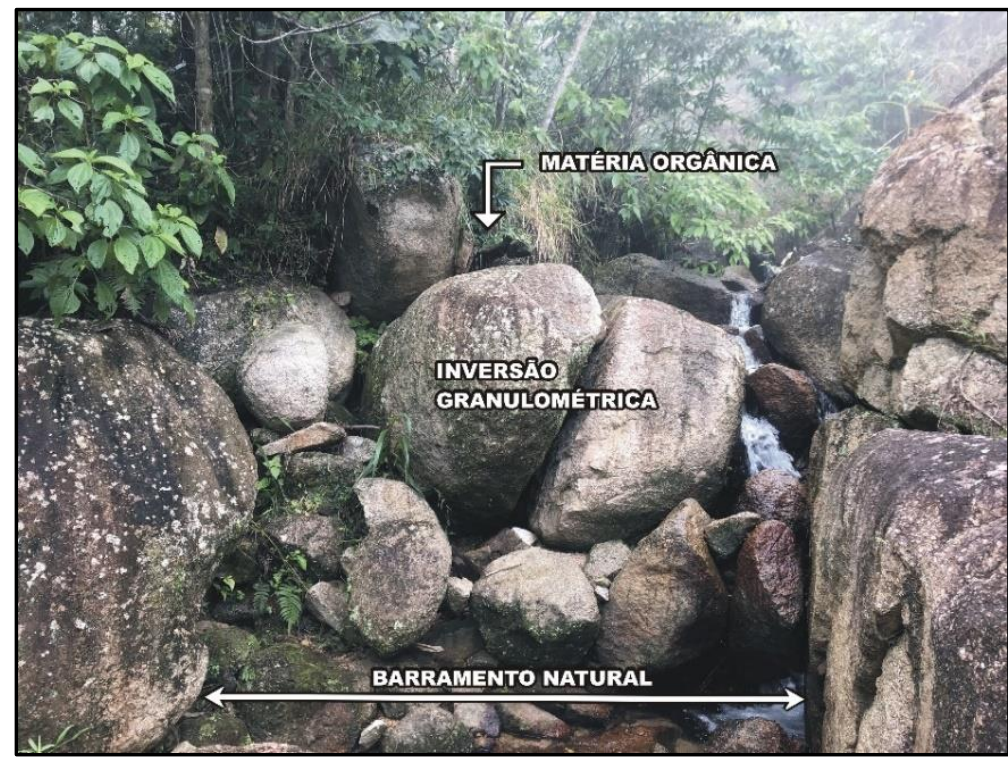


Figura 4.25: Feições encontradas no P4 da Bacia Guarda-mão I, com destaque para a ilha de deposição formada.

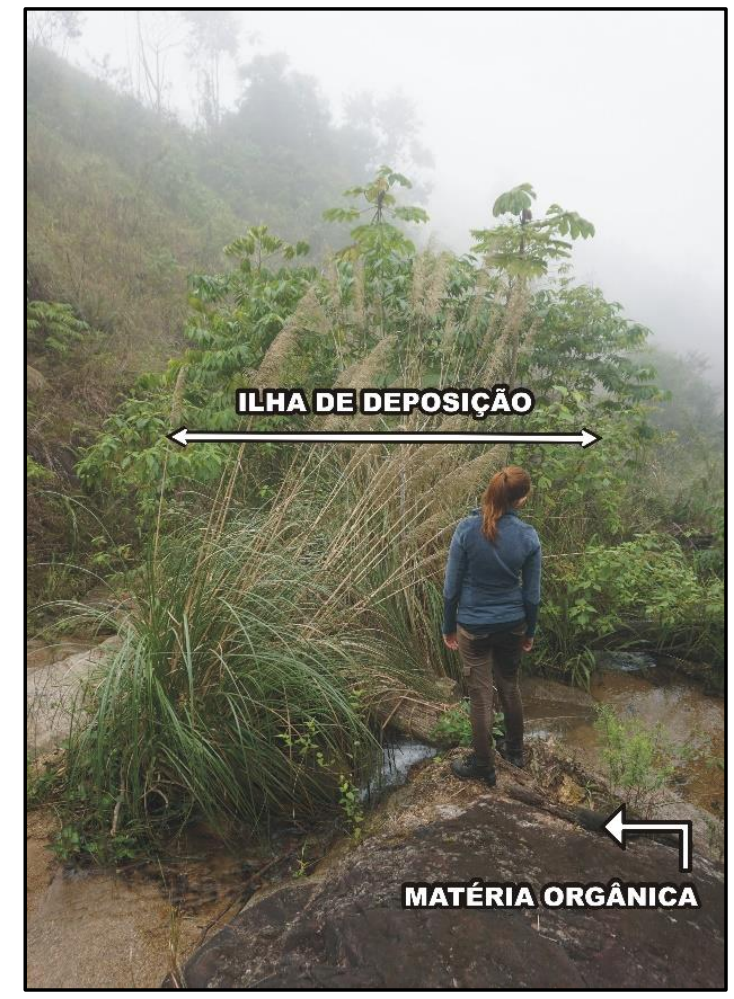

As feições apresentam características da passagem do fluxo, com destaque para a presença de matéria orgânica e "Levees" (Figuras 4.26 e 4.27). A regeneração da cobertura vegetal foi rápida, estando a maior parte dos depósitos parcialmente cobertos por vegetação pioneira, dificultando a sua visualização.

Figura 4.26: Feições encontradas no P2 da Guarda-mão I.

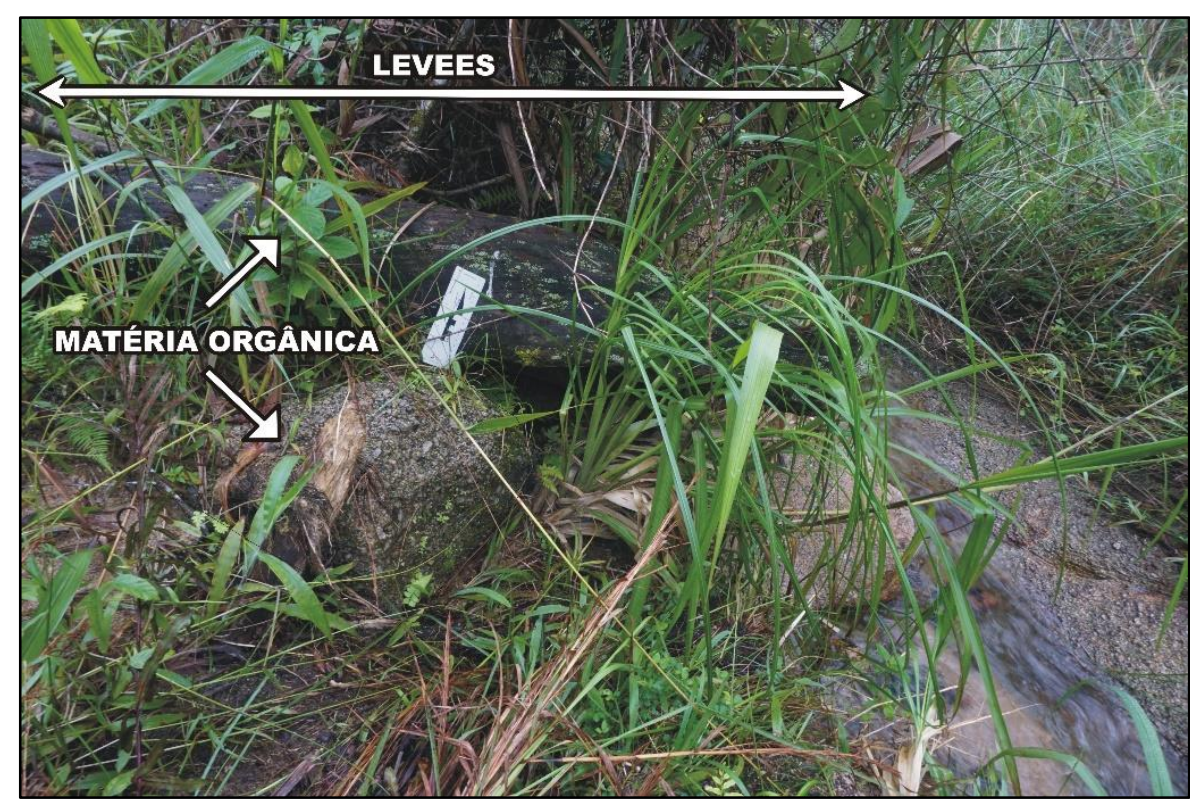


Figura 4.27: Feições encontradas no P3 da Guarda-mão I.

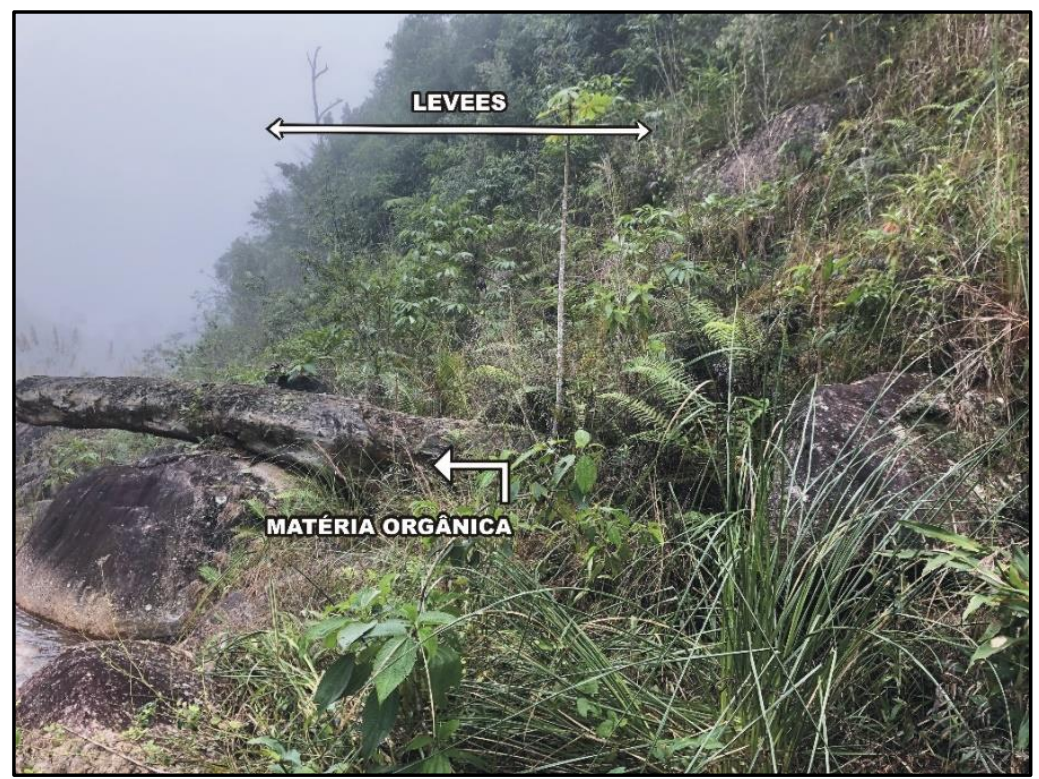

Os pontos P5 e P6 estão localizados na área da bacia onde ocorre a abertura do vale em direção a jusante, proporcionando, assim, uma maior área mais suave do relevo para deposição (Figura 4.28a). Após percorrer a maior parte de seu trajeto por um canal estreito e profundo, com média de 47,75 metros de largura, o fluxo chegou à área mais plana e amplamente aberta da bacia com mais de 100 metros de largura, ocorrendo a deposição espraiada dos blocos (Figura 4.28b), a designada "deposição principal" da corrida de detritos. Aqui destacam-se a presença de grandes blocos (maiores que 2 metros de diâmetro), e inversão granulométrica.

Figura 4.28: Espraiamento dos blocos na bacia Guarda-mão em área de abertura do relevo, em imagem de 2014, logo após o evento (a). Em imagem atual, de 2019, os blocos encontram-se parcialmente cobertos por restos de matéria orgânica após queimada realizada na área (b). Vista de jusate para montante.

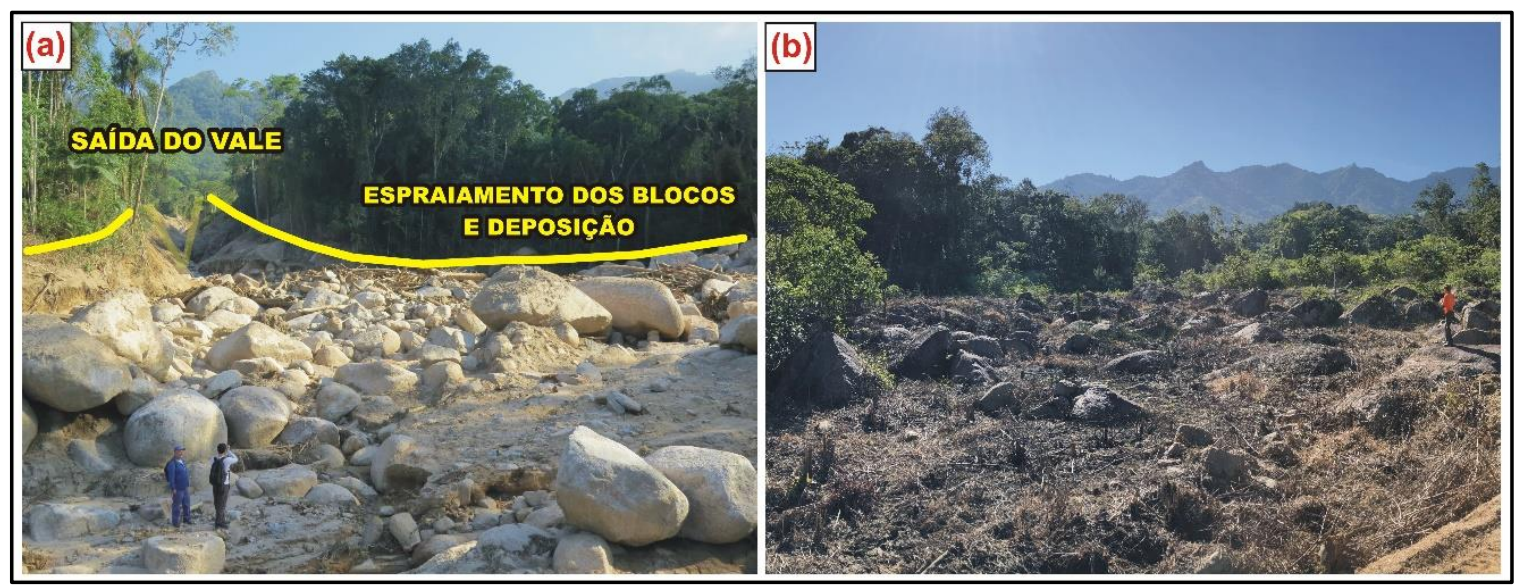

Fonte: fotografia de M. F. Gramani (2014) (a). 
O P5 está localizado logo abaixo da abertura do vale configurando o início da deposição dos detritos mais grosseiros. As feições identificadas foram a inversão granulométrica (Figura 4.29a) e, principalmente, a presença de blocos muito grandes (Figura 4.29b), que não foram encontrados nos pontos anteriores. Neste ponto, não ocorreu a retirada da vegetação por queimadas promovidas pelos moradores da região, estando os depósitos encobertos por vegetação pioneira abundante, que dificultaram a identificação das feições características das corridas de detritos. A Figura 4.30 ilustra a mudança ocorrida em uma mesma área no período de 5 anos, onde é possível verificar que o depósito composto por blocos com mais de 2 metros de diâmetro encontra-se parcialmente oculto pela vegetação, assim como sedimentos mais finos e os blocos menores que deram suporte para os blocos maiores.

Figura 4.29: Feições identificadas no P5, na bacia Guarda-mão I, na margem esquerda do canal (a). Detalhe para visão frontal do bloco de tamanho muito grande (> 2 metros de diâmetro) (b).

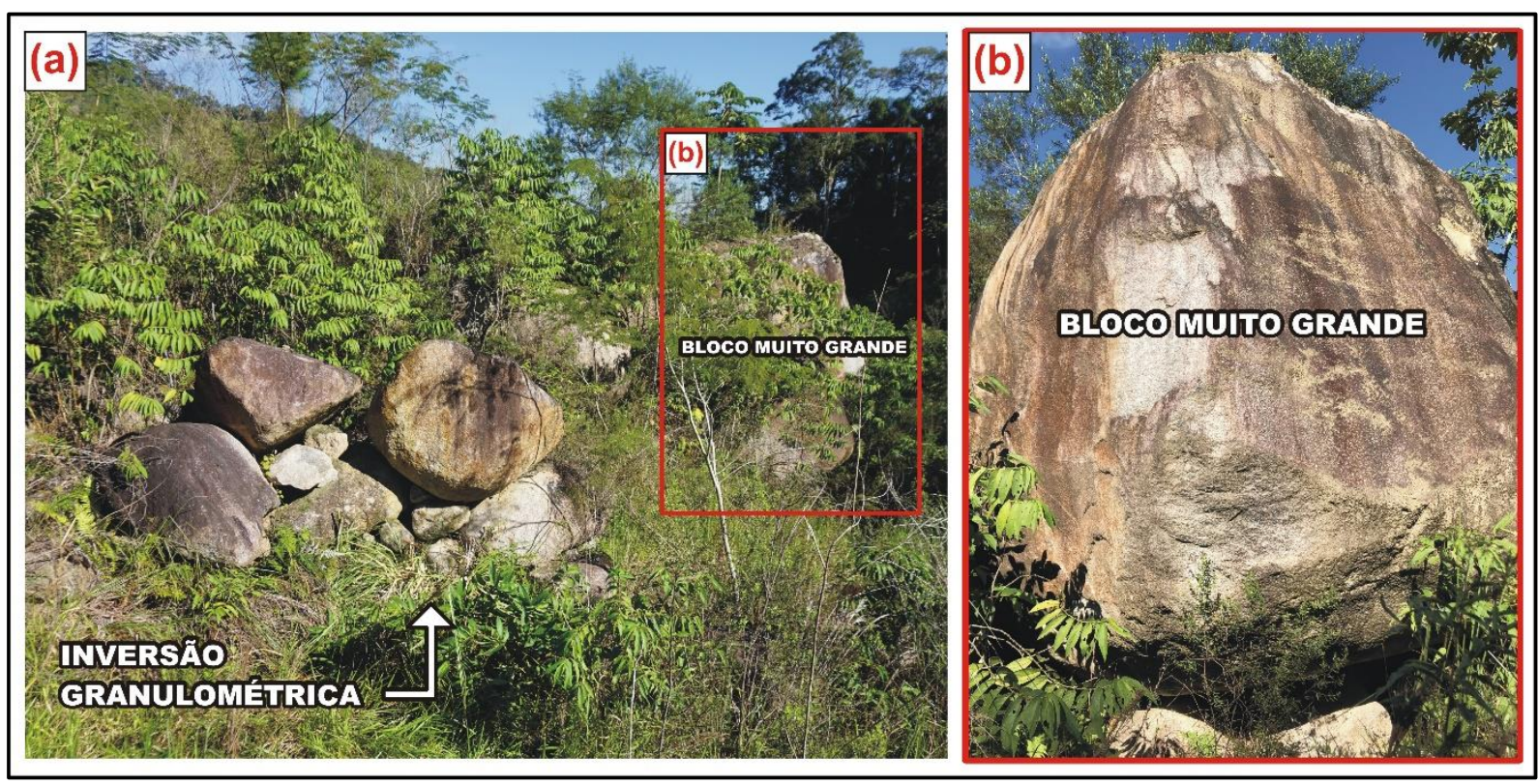


Figura 4.30: Depósitos de corridas de detritos e feições identificadas, logo após o evento, em 2014 (a) e 5 anos depois, em 2019 (b). Apesar de possuírem ângulos diferentes, ambas as imagens foram tiradas no mesmo local, do mesmo depósito. As cores identificam os blocos na imagem de 2014 (sem vegetação) e na imagem de 2019 (com vegetação).

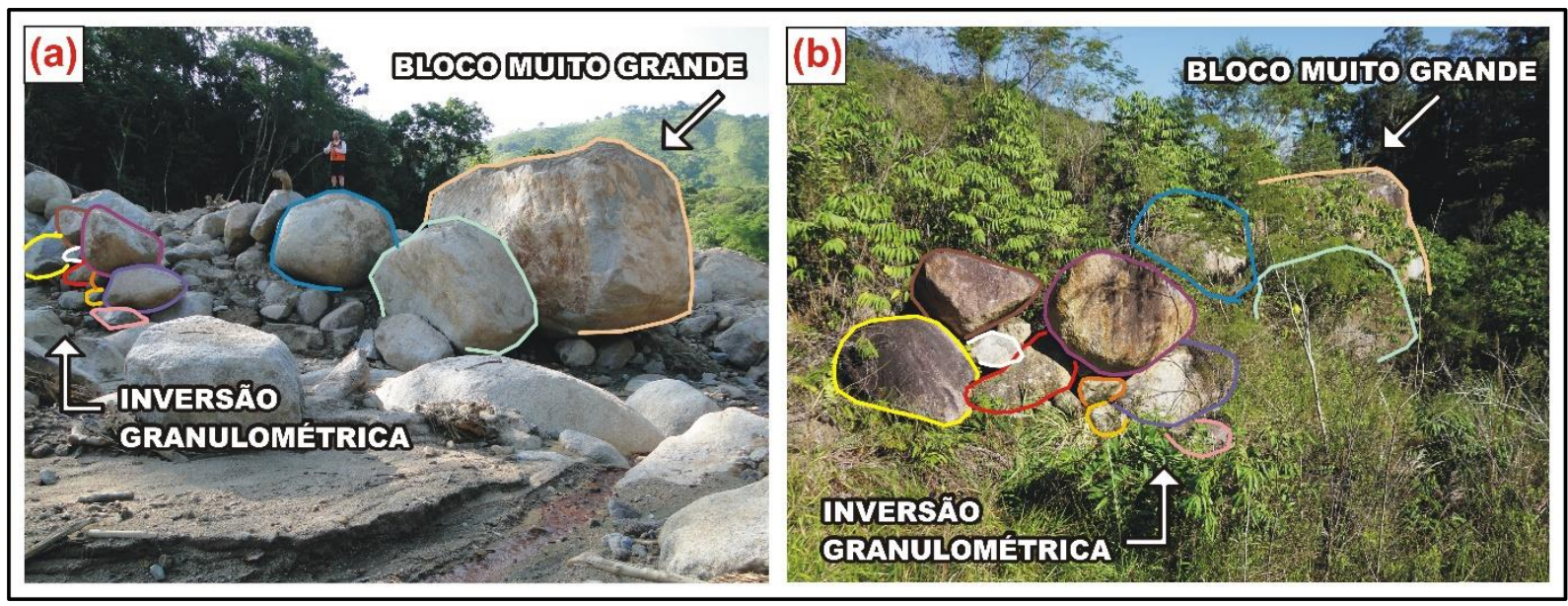

Fonte: fotografia de M. F. Gramani (a).

O P6 encontra-se um pouco à frente do ponto anterior, em área mais aberta, onde aconteceu a maior parte da deposição na saída do vale fechado, ocorrendo um espraiamento dos blocos e formação de um depósito em leque. As feições aqui encontradas foram a inversão granulométrica e presença de blocos muito grandes (Figura 4.31).

Figura 4.31: Vista aérea do depósito no P6, com destaque para o tamanho dos blocos em comparação ao carro.

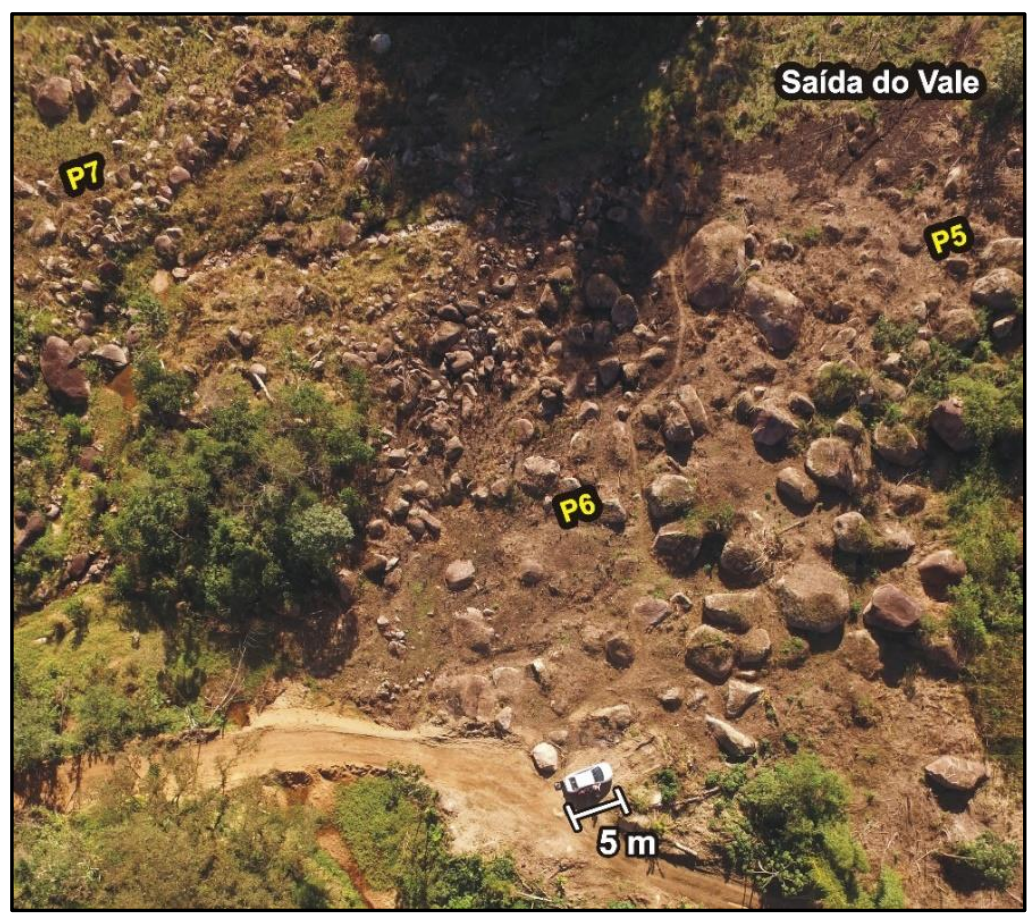

Fonte: imagem de drone cedida M. F. Gramani. 
Assim como no P4 na bacia Tingidor, o P6 apresentou sedimentos finos sobre os blocos de tamanho muito grande (Figura 4.32), sendo um indicativo da altura do fluxo no momento da deposição dos sedimentos.

Figura 4.32: Feições encontradas no P6 (a), com destaque para os sedimentos fino sobre os blocos (b).

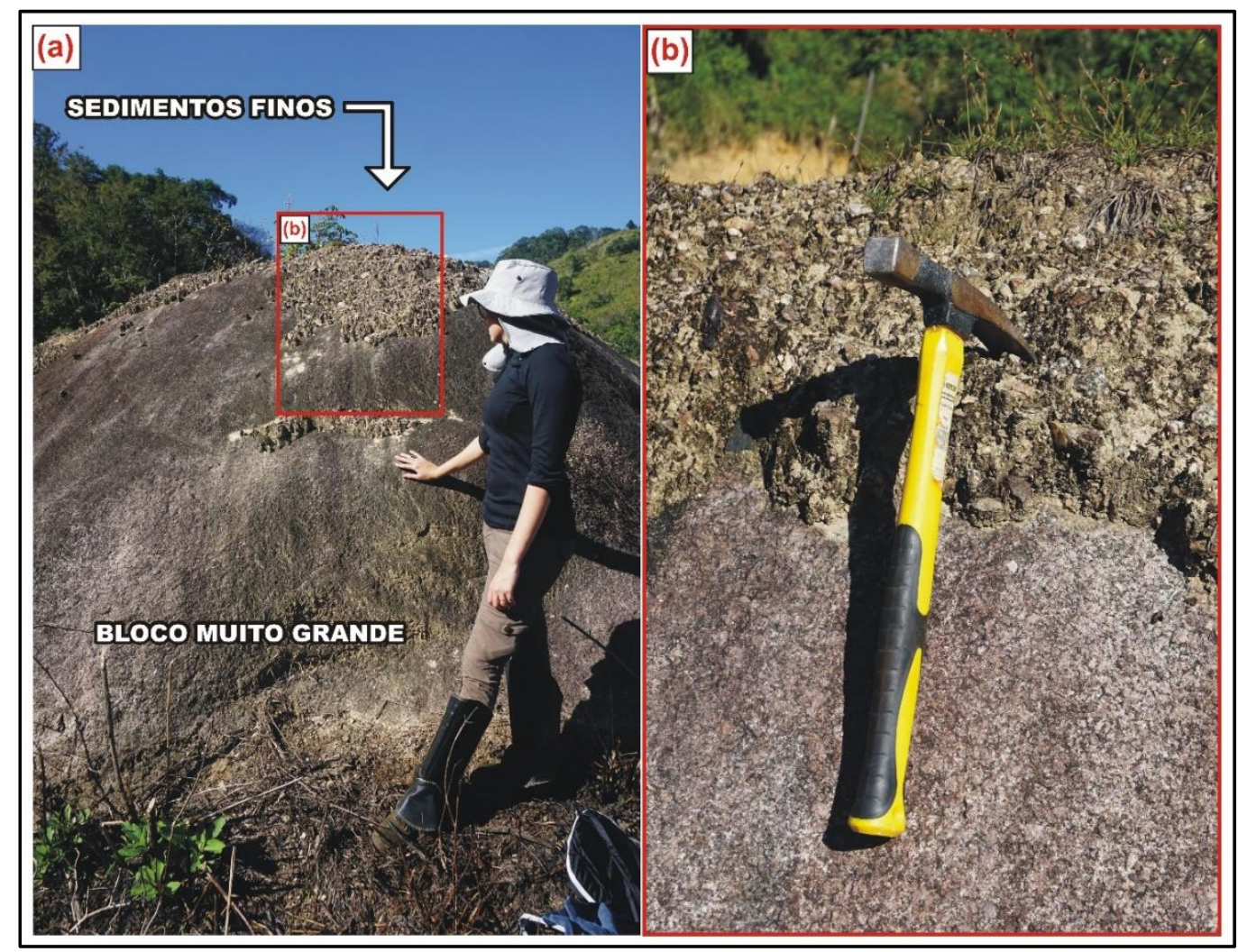

Os depósitos identificados no $\mathbf{P 7}$ e $\mathbf{P 8}$ estão localizados à frente da área de deposição principal, indo até o encontro do rio Guarda-mão com o rio Palmital, que corta o centro urbano da cidade de Itaoca. Destaca-se comportamento semelhante verificado na bacia Tingidor, com diminuição da granulometria dos blocos (ausência de blocos de tamanho muito grande) e aumento da presença de matéria orgânica, no caso, grande quantidade de troncos de árvores (Figura 4.33).

As feições identificadas foram a presença de levees às margens do rio principal, inversão granulométrica e matéria orgânica (Figura 4.34). Há na área ainda restos de um veículo que foi arrastado pelas corridas de detritos na ocasião do evento, em meio aos troncos de árvore em deposição e blocos (Figura 4.35). Nestes pontos, não houve a retirada da vegetação pelos moradores, sendo esta composta por vegetação pioneira, desenvolvida após a ocorrência da corrida de detritos, sobre os depósitos. 
Figura 4.33: Feições encontradas no P7 (a) e P8 (b).

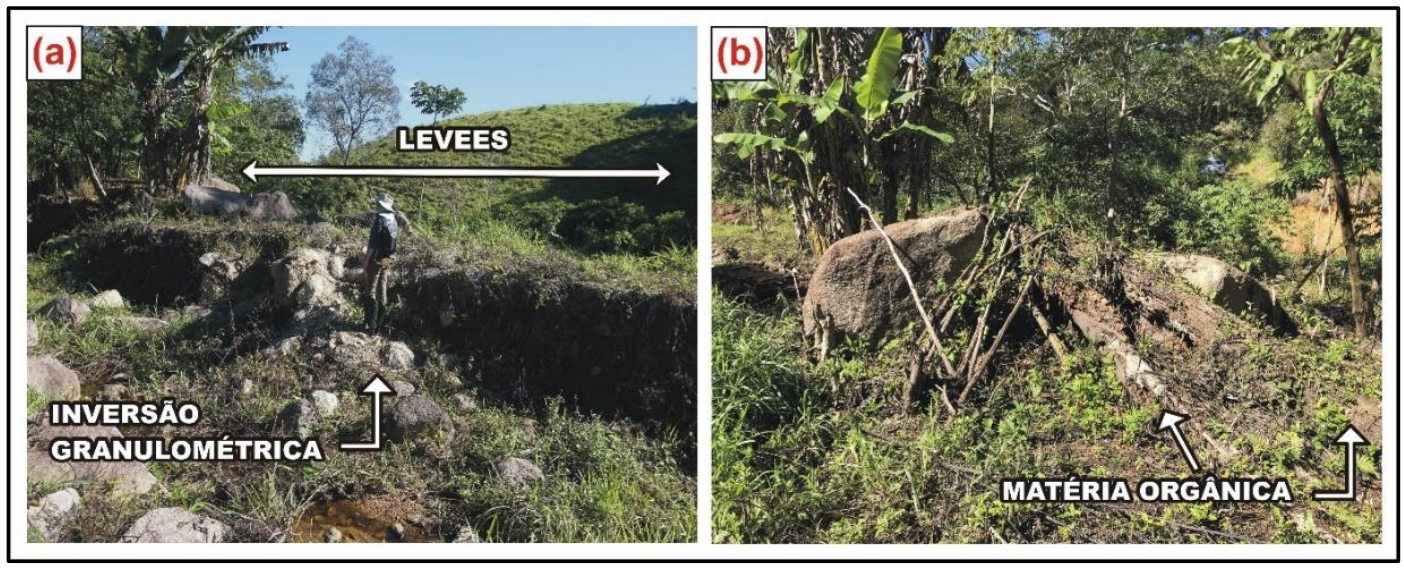

Figura 4.34: Feições encontradas no depósito no P7, na margem esquerda do rio.

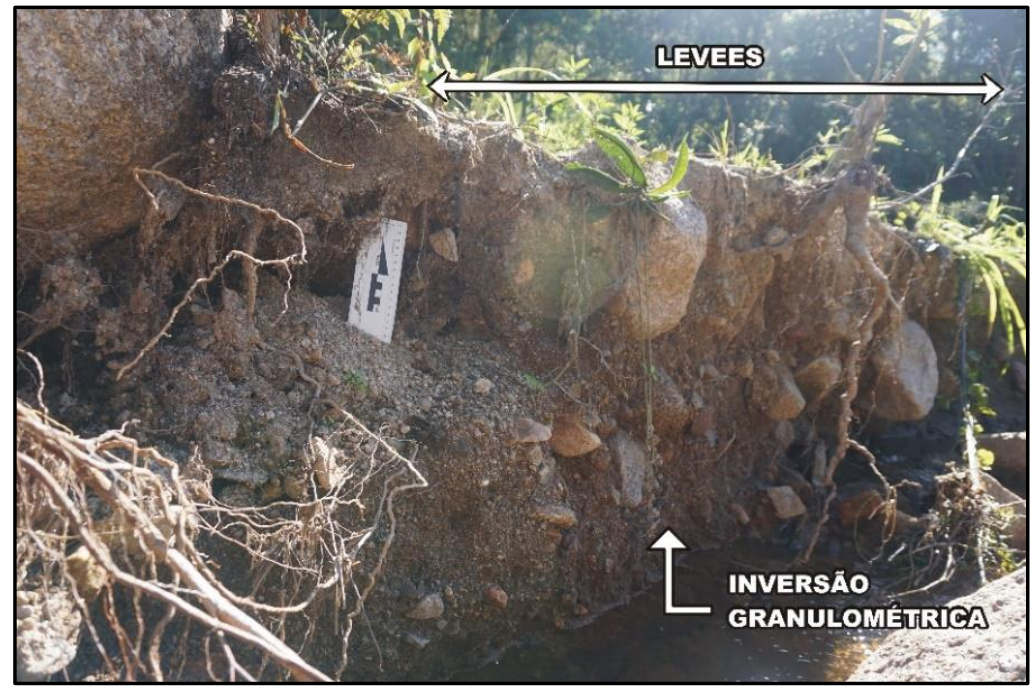

Figura 4.35: Veículo depositado no P8, em meio aos blocos e matéria orgânica.

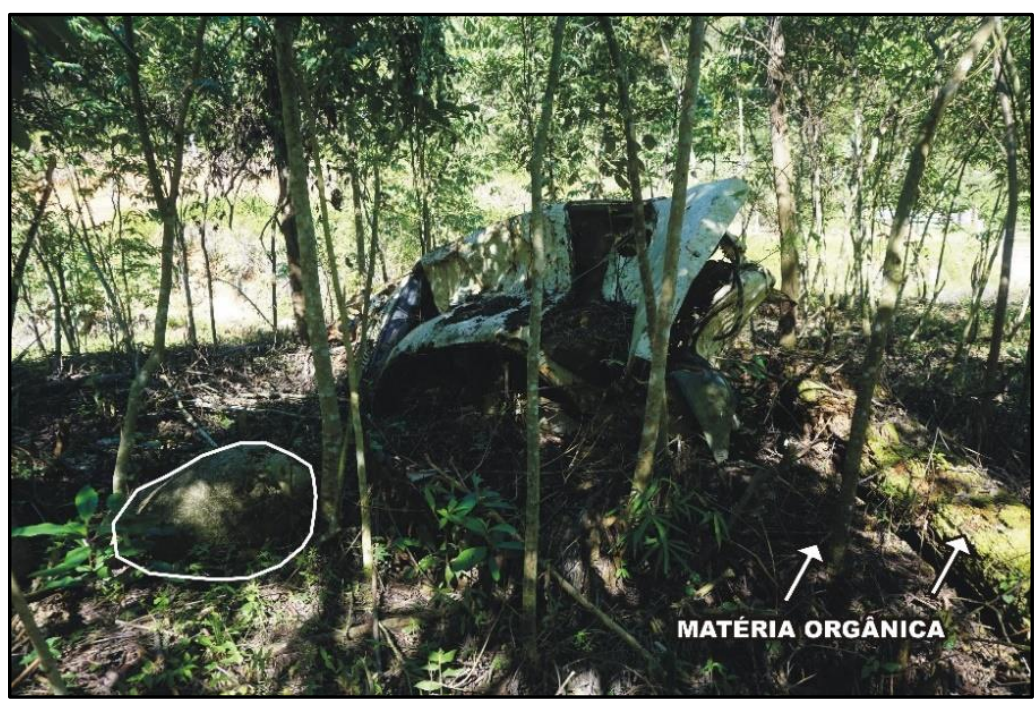




\subsubsection{Pico de vazão e velocidade}

Os resultados mostraram que as seções localizadas na denominada área de depósito principal apresentaram maiores valores Q e U (Tabela 4.3). As seções P2 - P4 na bacia Tingidor e P5 e P6 na bacia Guarda-mão I apresentaram vazão de fluxo entre 7.139,99 e $10.134,2 \mathrm{~m} 3 / \mathrm{s}$, e velocidades entre 9,7 e $11,45 \mathrm{~m} / \mathrm{s}$. Tais valores estão de acordo com as feições observadas em campo em cada seção, com a presença de blocos muito grandes (> $2 \mathrm{~m}$ de diâmetro) e grande quantidade de materiais depositados.

As seções P1 na Tingidor e P1 a P4 na Guarda-mão I apresentaram os menores valores de vazão de fluxo e velocidade, entre $1.033,27$ e $2.489,74 \mathrm{~m} 3 / \mathrm{s}$ e 6,8 e $8,6 \mathrm{~m} / \mathrm{s}$, respectivamente. Estas seções foram classificadas como parte da zona de transporte, e tal variação pode ser explicada pela dinâmica das corridas de detritos, considerando zona de iniciação, transporte e deposição inicialmente propostas por VanDine (1996) e a evolução da corrida de detritos ao longo do canal considerando as especificações geomorfológicas do mesmo.

Tabela 4.3: Resultados para Pico de vazão (Q) e Velocidade (U) nas bacias Tingidor e Guarda-mão I.

\begin{tabular}{c|ccc|ccc}
\multicolumn{3}{c}{ TINGIDOR } & \multicolumn{3}{c}{ GUARDA-MÃO I } \\
\cline { 2 - 7 } SEÇÃO & Distância $(\mathbf{m})$ & $\mathbf{Q}\left(\mathbf{m}^{\mathbf{3}} \mathbf{s}\right)$ & $\mathbf{U}(\mathbf{m} / \mathbf{s})$ & Distância $(\mathbf{m})$ & $\mathbf{Q}\left(\mathbf{m}^{3} / \mathbf{s}\right)$ & $\mathbf{U}(\mathbf{m} / \mathbf{s})$ \\
P1 & 2.120 & $2.156,78$ & 7,8 & 1.300 & $2.056,97$ & 8,4 \\
P2 & 2.280 & $3.892,25$ & 9,7 & 1.350 & $2.489,78$ & 8,6 \\
P3 & 2.420 & $5.081,14$ & 9,92 & 1.400 & $1.033,27$ & 6,8 \\
P4 & 2.570 & $10.134,2$ & 11,45 & 1.450 & 895,08 & 7,2 \\
P5 & 3.000 & $14.597,9$ & 11,65 & 2.600 & $7.139,99$ & 11,42 \\
P6 & 3.500 & $7.570,81$ & 7,9 & 2.720 & 624,19 & 4,14 \\
P7 & ------ & ----- & ----- & 2.900 & 475,71 & 6,68 \\
P8 & ----- & ----- & ----- & 3.000 & 113,59 & 3,9
\end{tabular}

A bacia Tingidor apresentou ao menos três pulsos a partir de diferentes escorregamentos na zona de iniciação, os quais convergiram para o canal principal se constituindo em um fluxo único ao longo de um vale em $\mathrm{V}$ confinado, iniciando o processo de deposição na medida que ocorre uma diminuição do confinamento (Figura 4.11).

A seção P1 está localizada ao final da zona de transporte e apresentou os menores valores de Q e U $(2.156,78$ m³ $/ \mathrm{s}$ e $7,8 \mathrm{~m} / \mathrm{s})$. Da seção $\mathbf{P 2}$ em diante, inicia-se a chamada deposição principal, devido ao alargamento do canal e menor gradiente altimétrico, o que provocou um gradual aumento dos valores, que atingiram o seu pico na seção P5, chegando a $14.597,9$ m³/s de vazão de pico e 11,65 m/s de velocidade, mesmo após o início da deposição. 
A seção P5 apresentou intensa erosão das margens do rio causada majoritariamente pelo impacto, dada a intensidade do fluxo. Os valores começam a decair somente a partir do P6, no entanto, o Q ainda apresenta um maior valor em comparação às seções P2 e P3. Apesar de não ter sido considerada parte da deposição principal, a seção P5 apresentou os maiores valores de Q e U $(14.597,9$ m³/s e 11,65 m/s), cuja explicação reside nas características geomorfológicas da bacia Tingidor. Após a deposição principal entre as seções P2 e P4, ocorre um drástico estreitamento do canal e o aumento do gradiente altimétrico, o que pode ter contribuído para um reconfinamento do fluxo, aumentando o Q e U. Dessa forma, quando ocorre novamente uma abertura do relevo, ocorre a deposição, ainda com maior intensidade e poder destrutivo, evidenciado pelos impactos causados na paisagem (Figura 4.36).

Figura 4.36: Gráfico de velocidade e pico de vazão da bacia Tingidor.

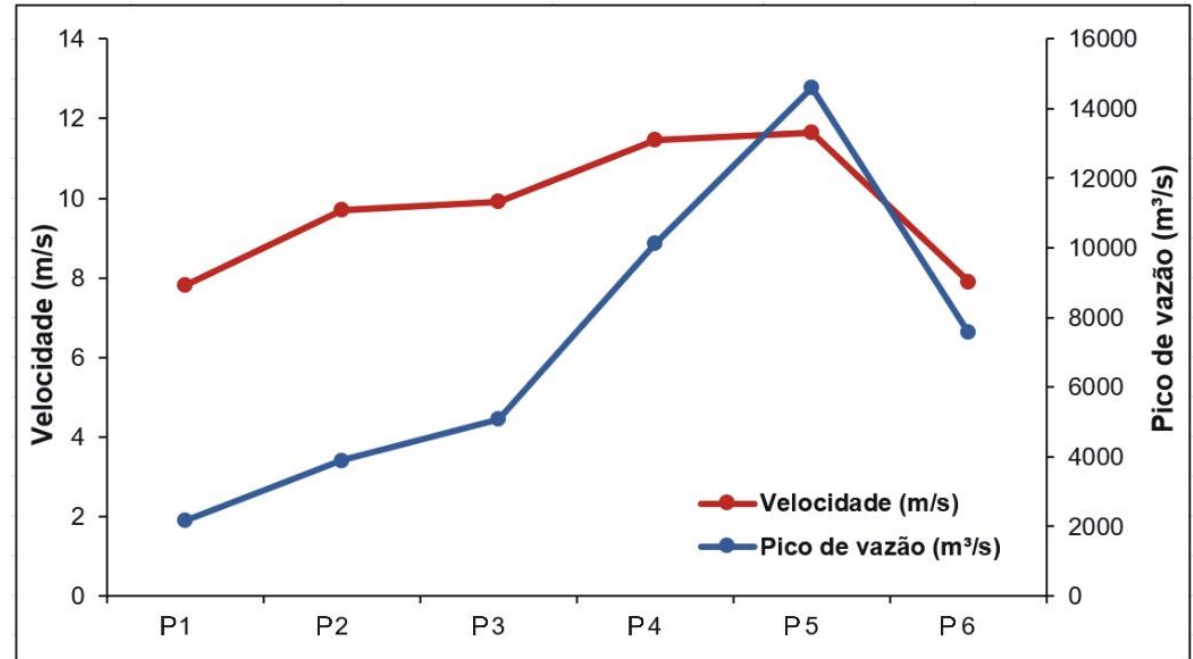

A bacia Guarda-mão I, por sua vez, possui um vale em V confinado desde a zona de iniciação na área mais íngreme e montanhosa da bacia até a planície, onde ocorre a abertura do relevo para uma ampla área de espraiamento (Figura 4.23). As seções P1 - P4 localizadas nas áreas mais proeminentes da bacia, sendo caracterizadas por um vale $\mathrm{V}$ profundo e estreito, o que pode ter contribuído para o transporte, erosão e arrastamento ao longo da corrida de detritos devido ao confinamento do fluxo. Quando o fluxo alcança as partes mais baixas do relevo na abertura do vale, os valores de Q e U atingem os picos antes da deposição.

A seção P5 está localizada na saída do vale, onde o fluxo é “desconfinado" e se deposita na planície principal da bacia em uma ampla área de espalhamento e menor gradiente altimétrico e atingindo os maiores valores de Q e U $(7.139,99 \mathrm{~m} / \mathrm{s}$ e $11,42 \mathrm{~m} / \mathrm{s})$. A seção $\mathbf{P 6}$ apresentou uma diminuição dos valores $\left(624,19 \mathrm{~m}^{3} / \mathrm{s}\right.$ e $\left.4,14 \mathrm{~m} / \mathrm{s}\right)$ uma vez que o fluxo atingiu a 
área mais aberta do vale, seguida por um ligeiro aumento na seção P7 $(475,71$ m³/s e 6,68 m/s) devido ao reconfinamento do fluxo. No entanto, o baixo gradiente do canal contribuiu para a posterior diminuição dos valores na seção P8 (113,59 m³/s e 3,9 m/s) (Figura 4.37).

Figura 4.37: Gráfico de velocidade e pico de vazão da bacia Guarda-mão I.

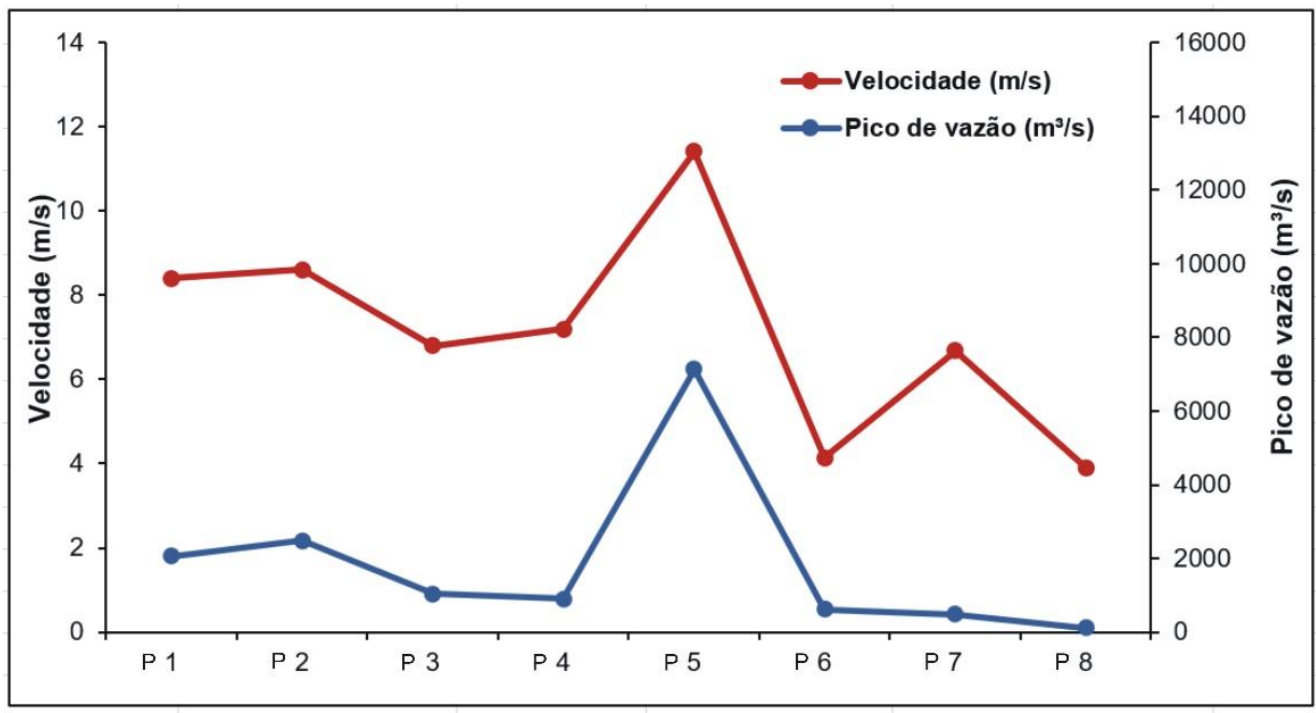

\subsubsection{Estimativa de volume de arrastamento e potencial magnitude}

Em ambas as bacias, as corridas de detritos foram iniciadas a partir do aporte de sedimentos oriundos de escorregamentos deflagrados nas encostas. Os resultados para volume (Tabela 4.4; Figura 4.38) mostram que, embora o $V_{i}$ tenha sido maior na bacia Tingidor (44.760,39 m³) em comparação a bacia Guarda-mão I $\left(1.247,00 \mathrm{~m}^{3}\right)$, o $V_{t}$ estimado na Guardamão I foi maior (237.673,00 m³ contra 196,880,39 $\mathrm{m}^{3}$ na Tingidor), com uma diferença de mais de $60.000 \mathrm{~m}^{3}$ entre as duas bacias. Neste caso, o $V_{i}$ de 1 escorregamento estimado em 1.247,00 $\mathrm{m}^{3}$ aumentou para $237.673,00 \mathrm{~m}^{3}$, majoritariamente devido ao arrastamento, apesar da bacia Tingidor possuir um $V_{i}$ estimado mais de 30 vezes maior que a Guarda-mão I. As diferenças de comprimento dos runouts entre as bacias indicam a relação entre comprimento do runout $\mathrm{e}$ aumento do arrastamento e $V_{t}$ da corrida de detritos, com a bacia Tingidor possuindo 1.521,20 $\mathrm{m}$ de runout e a bacia Guarda-mão I 2.364,26 m.

Os resultados do $V_{d p}$, composto majoritariamente por materiais grosseiros (em especial, grandes blocos) foi maior na Tingidor, com 143.907,57 m³ , em comparação à Guarda-mão I, com $131.657,46 \mathrm{~m}^{3}$. Este resultado indica que a maior parte do volume produzido pelo processo de arrastamento da corrida de detritos foi depositado na própria bacia, com um volume sobressalente de aproximadamente $50.000 \mathrm{~m}^{3}$ chegando até o canal principal da bacia Jacareí e 
contribuindo para os danos subsequentes à rodovia, localizada à aproximadamente 3,0 km da desembocadura da Tingidor no Rio Jacareí. Em comparação, embora grande parte do $V_{a}$ tenha sido depositado na bacia, estima-se que o volume aproximado de $100.000 \mathrm{~m}^{3}$ tenha atingido o canal principal do Rio Palmital, contribuindo para os danos causados ao centro urbano de Itaoca, localizado à aproximadamente $6,0 \mathrm{~km}$ da desembocadura do Guarda-mão I no Rio Palmital.

Tabela 4.4: Resultados de Volume $\left(\mathrm{m}^{3}\right)$ para ambas as bacias.

\begin{tabular}{r|cc|cc} 
VOLUMES & \multicolumn{2}{|c|}{ TINGIDOR } & \multicolumn{2}{c}{ GUARDA-M $\tilde{O} \mathbf{I}$} \\
\hline $\mathbf{V}_{\mathbf{i}}\left(\mathbf{m}^{\mathbf{3}}\right)$ & $44.760,39$ & $4,47 \times 10^{4}$ & $1.247,00$ & $1,24 \times 10^{3}$ \\
$\mathbf{V}_{\mathbf{a}}\left(\mathbf{m}^{3}\right)$ & $152.120,00$ & $1,52 \times 10^{5}$ & $236.426,00$ & $2,36 \times 10^{5}$ \\
$\mathbf{V}_{\mathbf{d p}}\left(\mathbf{m}^{3}\right)$ & $143.907,57$ & $1,43 \times 10^{5}$ & $131.654,46$ & $1,31 \times 10^{5}$ \\
$\mathbf{V}_{\mathbf{t}}\left(\mathbf{m}^{\mathbf{3}}\right)$ & $\mathbf{1 9 6 . 8 0 0 , 3 9}$ & $\mathbf{1 , 9 6 \times 1 0 ^ { 5 }}$ & $\mathbf{2 3 7 . 6 7 3 , 0 0}$ & $\mathbf{2 , 3 7} \times \mathbf{1 0}^{\mathbf{5}}$
\end{tabular}

Figura 4.38: Cálculo de volume para as bacias Tingidor e Guarda-mão I.

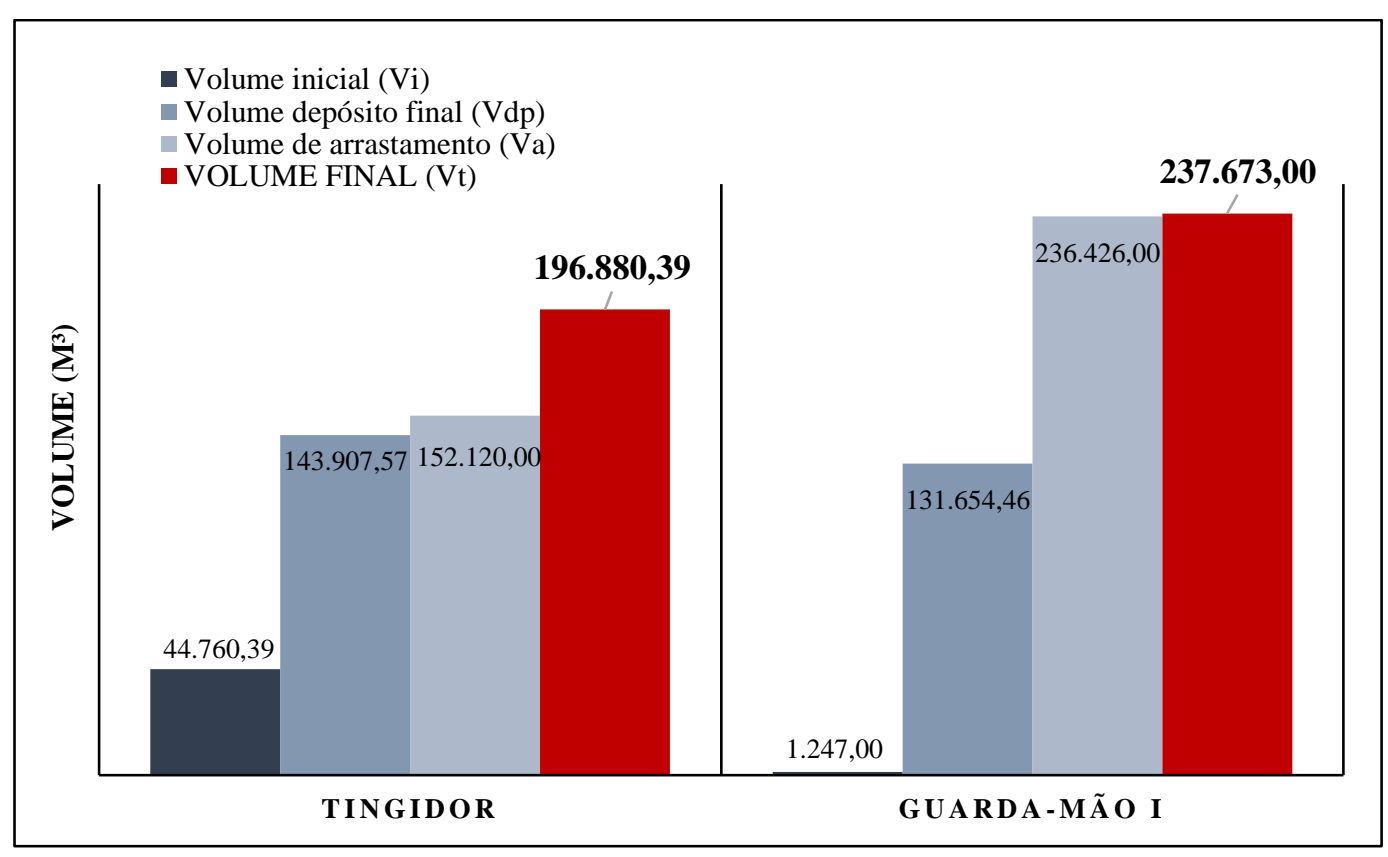


A magnitude potencial dos eventos foi calculada considerando o $V_{t}$ estimado $\left(\mathrm{m}^{3}\right)$ e o Q $\left(\mathrm{m}^{3} / \mathrm{s}\right)$, utilizando a classificação proposta por Jakob (2005a). Os resultados mostraram que a classificação das ocorrências está em acordo com os critérios utilizados e com as consequências potenciais previstas para cada classe (Tabela 4.5). Considerando o volume, ambas as bacias foram classificadas com nível 4 de magnitude, que possui como consequências potenciais "a destruição de partes de uma vila, destruição de infraestruturas e pontes, podendo bloquear canais”. Em contrapartida, considerando o pico de vazão, Tingidor e Guarda-mão I foram classificadas com maior magnitude, ambas no nível 5, com consequências potenciais sendo "a destruição de partes de uma cidade, destruição de florestas em um raio de $2 \mathrm{~km}^{2}$ e bloqueio de canais e rios". Levando em consideração o mapeamento dos depósitos e características dos materiais, a classificação nível 5 pode ser considerada a mais apropriada para ambas as bacias, devido aos altos valores de vazão de fluxo e velocidade, além do bloqueio de canais causado pelos blocos e destruição de residências.

Tabela 4.5: Classificação de magnitude com base em Jakob (2005a).

\begin{tabular}{c|cc|cc} 
CRITÉRIO & \multicolumn{2}{|c|}{ TINGIDOR } & \multicolumn{2}{c}{ GUARDA-MÃO I } \\
\hline $\mathbf{V}_{\mathbf{t}}\left(\mathbf{m}^{3}\right)$ & $10^{4}-10^{5}$ & Classificação 4 & $10^{4}-10^{5}$ & Classificação 4 \\
$\mathbf{Q}\left(\mathbf{m}^{3} / \mathbf{s}\right)$ & $>12.000$ & Classificação 5 & $1.500-12.000$ & Classificação 5
\end{tabular}

\subsubsection{Características pluviométricas}

Para a bacia Tingidor, as estações meteorológicas mais próximas são as estações Colônia Santa Cruz e Morretes, possibilitando a elaboração de média anual de 30 anos entre 1985 e 2015, e com os volumes correspondentes ao ano e mês de ocorrência do evento. Já para a bacia Guarda-mão I, a estação meteorológica mais próxima encontra-se no centro urbano do município, com dados pluviométricos disponíveis apenas até o ano 2000, permitindo a elaboração de média anal de 30 anos apenas a partir de 1970.

A média de precipitação anual próxima à bacia Tingidor varia entre as estações meteorológicas, com maior média anual registrada na estação Colônia Santa ( 3.000 mm/ano) em comparação à estação Morretes ( 2.500 mm/ano) (Figura 4.39a-1). A precipitação mensal multianual indica dois regimes predominantes, uma estação chuvosa entre os meses de novembro a março (> $300 \mathrm{~mm} / \mathrm{mês})$ e uma estação seca entre abril e outubro (<200 mm/mês) (Figura 4.39a-2).

Conforme observado no gráfico da distribuição multianual (Figura 4.39a-1), o ano de 2011 se destacou como um dos mais chuvosos, com destaque para o mês de março, com valores 
> 600 mm (Figura 4.39a-3). Em comparação à Tingidor, a bacia Guarda-mão I possui uma média anual de precipitação menor, com valores anuais abaixo de $2.000 \mathrm{~mm} /$ ano (Figura 4.39b-1). A distribuição mensal multianual também indica a predominância de dois regimes, uma estação chuvosa entre os meses de dezembro a fevereiro (> $150 \mathrm{~mm} / \mathrm{mês}$ ) e uma estação seca entre os meses de março a novembro (<100 mm/mês) (Figura 4.39b-2).

Figura 4.39: Característica da chuva nas bacias Tingidor (a) e Guarda-mão I (b) obtidos a partir de estações pluviométricas próximas às duas áreas: 1) Distribuição de chuva multianual; 2) Distribuição de chuva mensal multianual; e 3) Distribuição mensal de chuva para o ano de 2011 para a bacia Tingidor, com destaque para os volumes máximos de chuva para o mês de março (dados não disponíveis para a bacia Guarda-mão I).

(a)
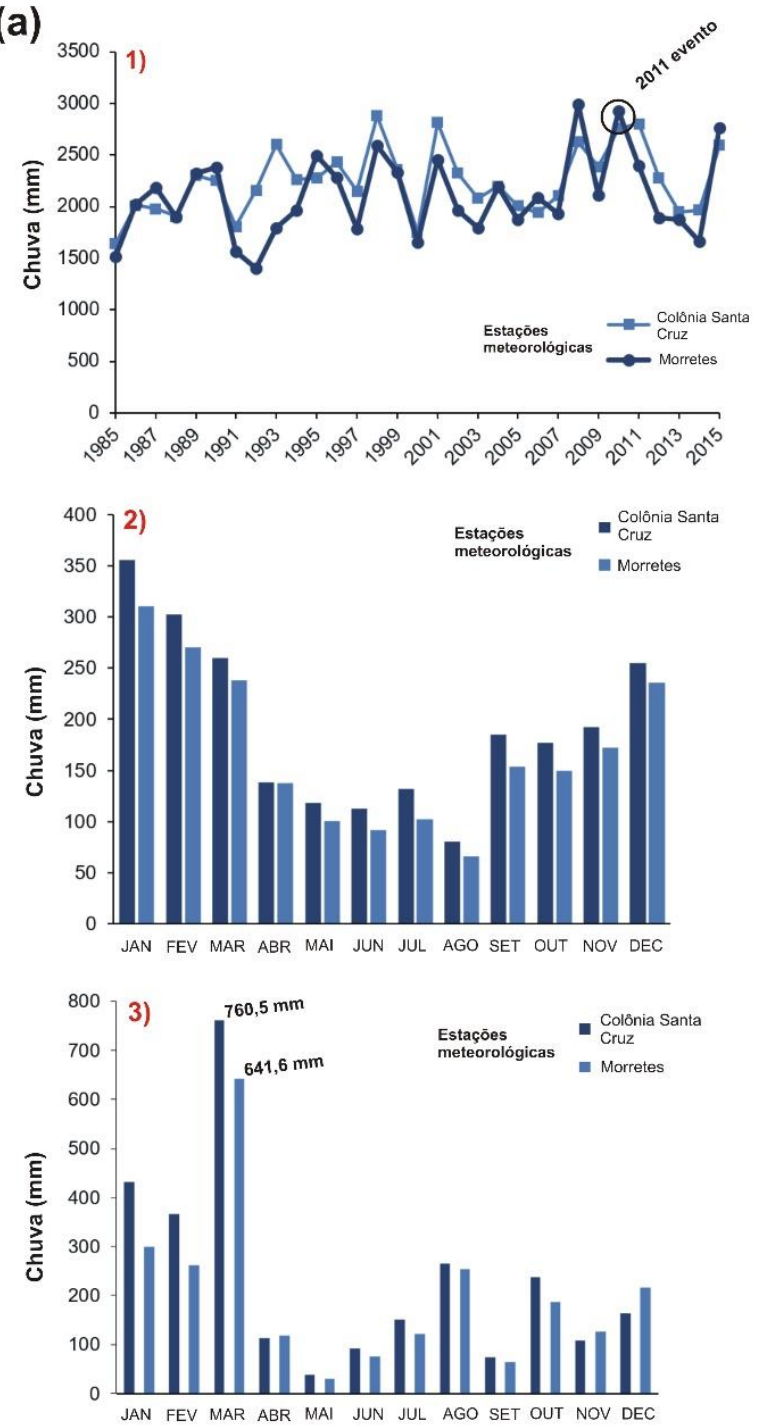

(b)
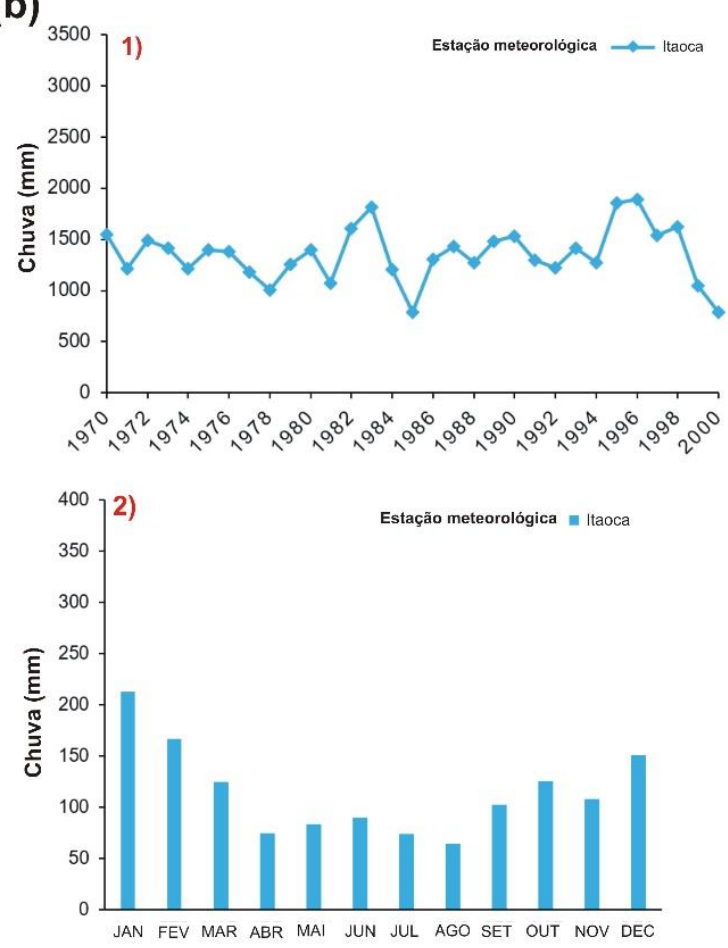

Fonte: Instituto das Águas do Paraná (a) e Departamento de Águas e Energia de São Paulo (DAEE) (b). 
A partir dos dados obtidos da missão GPM da NASA, foi possível estimar o volume pluviométrico que efetivamente afetou as áreas das bacias (Figura 4.40). Para a bacia Tingidor, no dia anterior ao evento estima-se que tenha chovido entre 15 e $16 \mathrm{~mm}$, e para o dia do evento entre 130 e 160 mm. Já para a bacia Guarda-mão I, o valor estimado para o dia anterior à deflagração do evento foi maior do que para o dia do evento, com os valores entre 35 e $40 \mathrm{~mm}$ e 30 e $35 \mathrm{~mm}$, respectivamente. De acordo com estes dados, estima-se que o volume de chuva que atingiu a bacia Tingidor tenha sido um acumulado de $176 \mathrm{~mm}$, enquanto para a Guardamão I estima-se um valor total acumulado de $75 \mathrm{~mm}$ para a deflagração dos processos de movimentos de massa (Figura 4.41).

Figura 4.40: Volume pluviométrico com base no Global Precipitation Measurement (GPM) da NASA para as áreas estudas no dia anterior ao evento ( $\mathbf{a}$ e b $\mathbf{b})$ e no dia de deflagração dos processos $(\mathbf{c}$ e d).

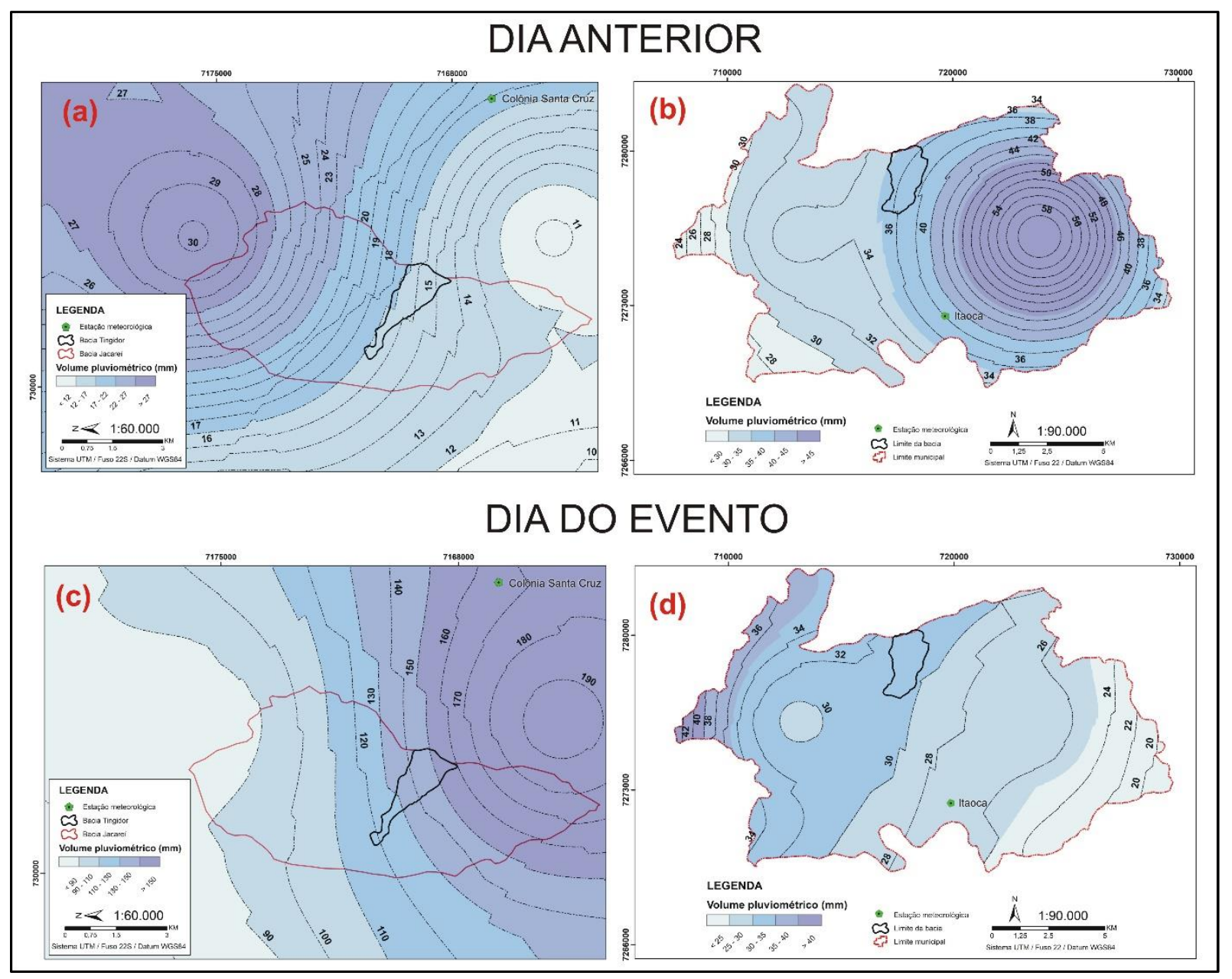


Figura 4.41: Gráfico do volume total acumulado para as áreas de estudos de acordo com Global Precipitation Measurement (GPM) da NASA.

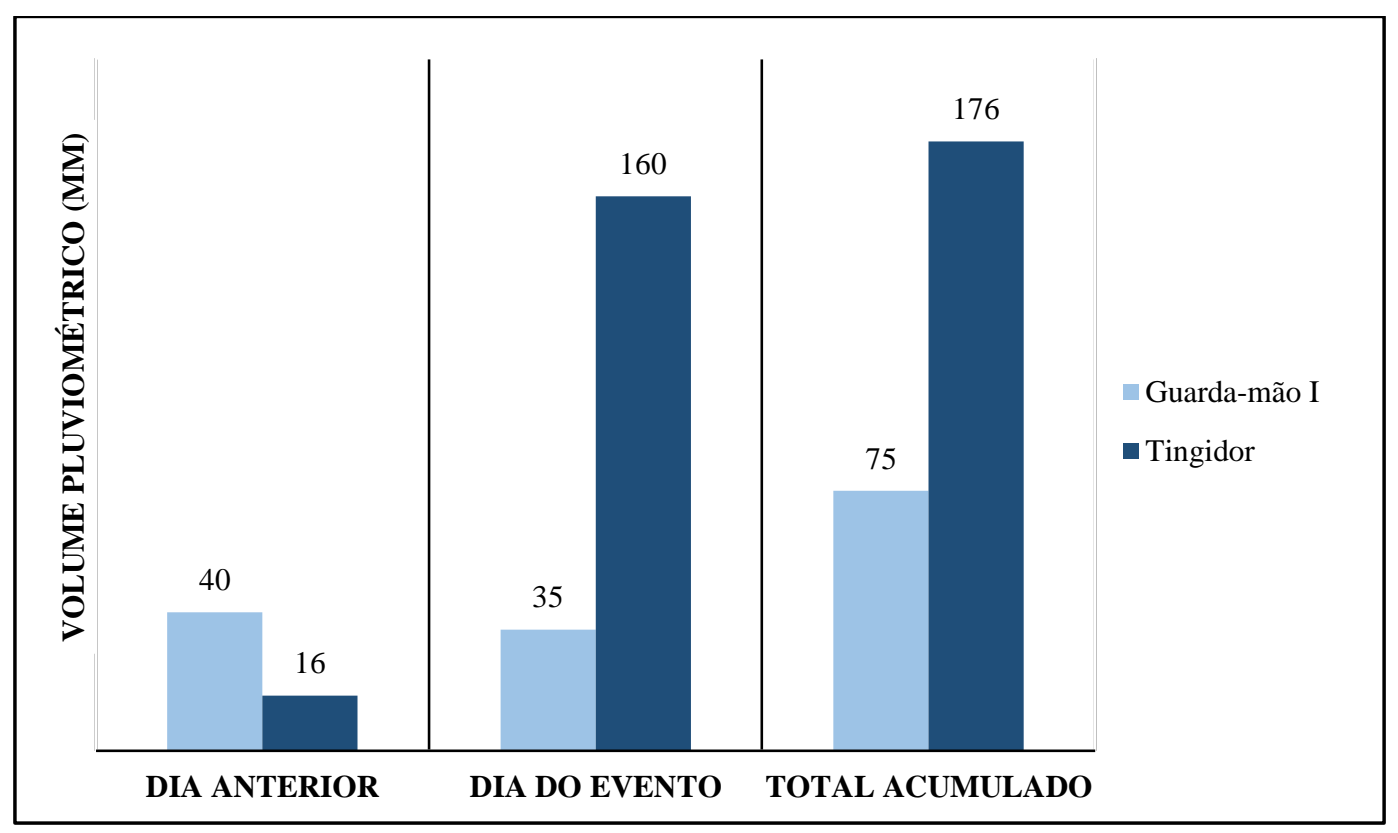




\subsection{Discussões}

As feições de corridas de detritos identificadas mostraram similaridades com feições encontradas em diferentes áreas com ocorrência de corridas de detritos, com destaque para os eventos recentes em Montecito, Califórnia, em 2018 (KEAN et al., 2019) e em Putumayo, na Colômbia, em 2017 (GARCÍA-DELGADO; MACHUCA; MEDINA, 2019) (Figura 4.42)

Os resultados obtidos para o $\mathrm{Q}$ e para $\mathrm{U}$ apresentaram valores compatíveis com o transporte de blocos com dimensões maiores que 10,0 metros de diâmetro, como aqueles identificados nas bacias Tingidor e Guarda-mão I. As velocidades características de corridas de detritos possuem uma tendência média entre 0,5 e 10,0 m/s (COUSSOT; MEUNIER, 1995), no entanto, os valores tendem a variar de acordo com o método usado no cálculo e nas especificidades de cada área.

No canal Kamikamihorizawa, Takahashi (2007) registrou velocidades entre 0,5 e 17,0 $\mathrm{m} / \mathrm{s}$, com as velocidades do fluxo oscilando devido à constrições no canal, semelhante à dinâmica observada na Tingidor e Guarda-mão I, nas quais o confinamento e reconfinamento do fluxo devido à mudanças topográficas podem ter contribuído para a variação do pico de vazão e da velocidade. O material mobilizado na corrida de detritos Mocoa apresentou blocos com até 9 metros de diâmetro e as velocidades variaram entre 4,82 e 12,02 m/s (GARCÍADELGADO; MACHUCA; MEDINA, 2019), similares aos valores calculados para as bacias Tingidor e Guarda-mão I (entre 3,9 e 11,65 m/s), inclusive, utilizando a mesma técnica para o cálculo da velocidade e pico de vazão.

Figura 4.42: Depósitos de corridas de detritos em Montecito, Califórnia (a - c) e em Mocoa, Colômbia (d - f).

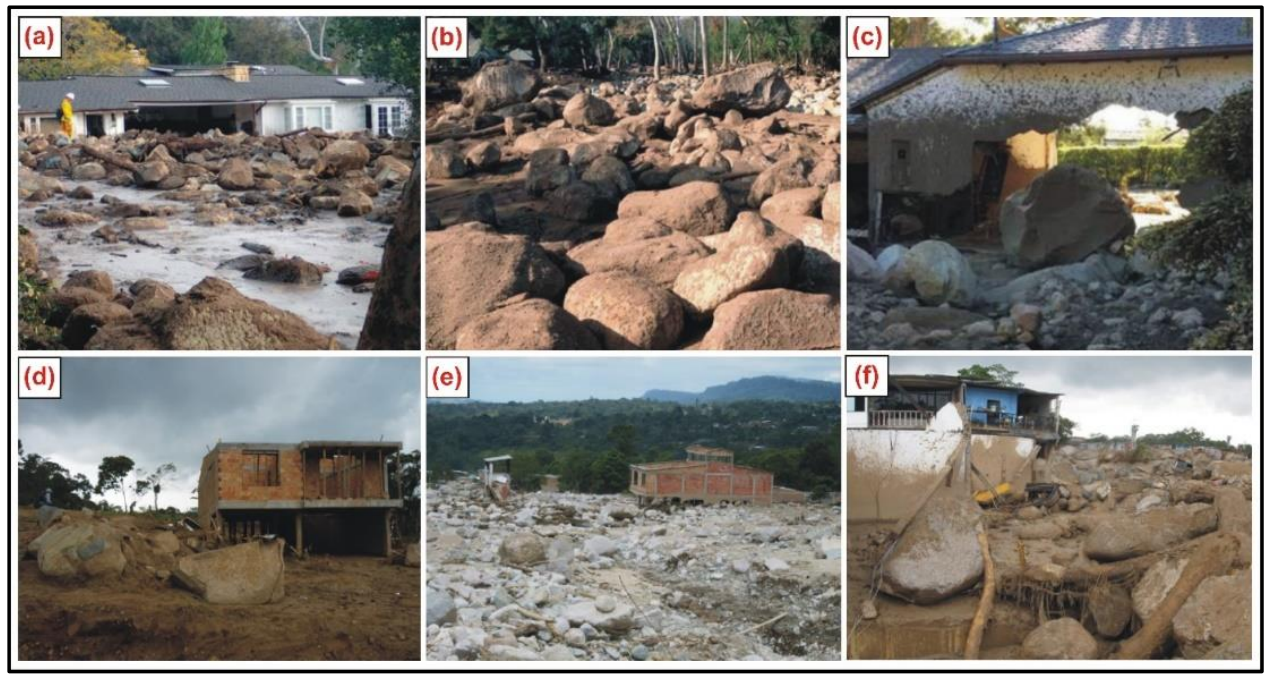

Fonte: modificado de Kean et al. (2019) (a - c) e García-Delgado; Machuca; Medina (2019). 
A ocorrência conjunta entre corridas de detritos e escorregamentos rasos é comum no Brasil (AVELAR et al., 2013; COELHO-NETTO; AVELAR; LACERDA, 2009; DE PLOEY; CRUZ, 1979; JONES, 1973) e em alguns eventos recentes em diferentes partes do mundo (CUI et al., 2013; GARCÍA-DELGADO; MACHUCA; MEDINA, 2019; GARCÍA-MARTÍNEZ; LÓPEZ, 2005), sendo os escorregamentos responsáveis por contribuir para a deflagração das corridas de detritos a partir do aporte de materiais (IVERSON, 1997).

Embora as bacias Tingidor e Guarda-mão I possuam esta relação entre os escorregamentos para a deflagração de corridas de detritos, os resultados mostraram que o processo de arrastamento desempenhou um papel fundamental no $V_{t}$ mobilizado pelo processo. A bacia Tingidor apresentou volume maior de sedimentos provindos dos escorregamentos em comparação à Guarda-mão I ( 44.000 e $\sim 1.200 \mathrm{~m}^{3}$, respectivamente), no entanto, esta última obteve um $V_{t}$ maior ( $237.000,00 \mathrm{e} \sim 196.000,00 \mathrm{~m}^{3}$, respectivamente) devido à maior distância de runout e mecanismo de arrastamento.

A relação entre distância de runout e o $V_{t}$ em processo de tipo fluxo como as corridas de detritos já foi apontada por diversos pesquisadores (ABELE, 1997; COE et al., 2021; GARCÍA-DELGADO; MACHUCA; MEDINA, 2019; HUNGR; MCDOUGALL; BOVIS, 2005; KING, 1996; MCDOUGALL; HUNGR, 2005; PIRULLI; PASTOR, 2012) (Tabela 4.6). King (1996) reportou o $V_{i}$ de $350 \mathrm{~m}^{3}$ que aumentou para o $V_{t}$ de quase $20.000 \mathrm{~m}^{3} \mathrm{com}$ um comprimento de runout de 1.035 m na corrida de detritos de Tsing Shan, em 1990, na China. Comparativamente, a ocorrência na Lei Pui Street em 2001, também na China apresentou o $V_{i}$ de $250 \mathrm{~m}^{3}$ e um aumento para o $V_{t}$ de $780 \mathrm{~m}^{3}$ devido a um runout significativamente menor, 300 m (MAUNSELL GEOTECHNICAL SERVICES LTD, 2002). Em 1999 uma avalanche de rochas em Nomash River, Western Vancouver Island, no Canadá teve um $V_{i}$ de $300.000 \mathrm{~m}^{3}$ aumentado para $\sim 600.000 \mathrm{~m}^{3}$ majoritariamente devido à adição de colúvio e till adicionados durante o transporte (MCDOUGALL; HUNGR, 2005). A corrida de detritos de Fjarland no oeste da Noruega também teve como importante fator o mecanismo de arrastamento, no qual o $\mathrm{V}_{\mathrm{i}}$ de $\sim 25.000 \mathrm{~m}^{3}$ aumentou para $\sim 240.000 \mathrm{~m}^{3}$ devido à um runout de $\sim 2.000 \mathrm{~km}$ (BREIEN et al., 2008), cenário similar ao encontrado na avaliação da corrida de detritos da bacia Guardamão I. Mais recentemente, García-Delgado; Machuca; Medina (2019) reportou um $V_{i}$ provindo de escorregamentos de $3,44 \times 10^{6}\left(34.000 .000 \mathrm{~m}^{3}\right)$ com pelo menos $10 \%\left(3,44 \times 10^{3} / 3.440,000\right.$ $\mathrm{m}^{3}$ ) deste contribuindo como fonte para a deflagração de corridas de detritos, que apresentou um $V_{t}$ estimado de $2,6 \times 10^{6}\left(26.000 .000 \mathrm{~m}^{3}\right)$, quase 100 vezes maior que o $V_{i}$ estimado na corrida de detritos do Mocoa, em 2017. 
Tabela 4.6: Comparação do volume inicial $\left(\mathrm{m}^{3}\right)$ e final $\left(\mathrm{m}^{3}\right)$ de corridas de detritos em diferentes localidades.

\begin{tabular}{lccl}
\hline FONTE & $\boldsymbol{V}_{\boldsymbol{i}}\left(\mathbf{m}^{\mathbf{3}}\right)$ & $\boldsymbol{V}_{\boldsymbol{t}}\left(\mathbf{m}^{\mathbf{3}}\right)$ & LOCAL \\
\hline King (1996) & 350 & 20.000 & Tsing Shan, China \\
\hline $\begin{array}{l}\text { Maunsell } \\
\begin{array}{l}\text { Geotechnical Services } \\
\text { LTD (2002) }\end{array}\end{array}$ & 250 & 780 & Lei Pui Street, China \\
\hline $\begin{array}{l}\text { McDougall; HUNGR } \\
\text { (2005) }\end{array}$ & 300.000 & 600.000 & $\begin{array}{l}\text { Nomash River, Western Vancouver } \\
\text { Island, Canadá }\end{array}$ \\
\hline Breien et al. (2008) & 25.000 & 240.000 & Fjærland, Noruega \\
\hline $\begin{array}{l}\text { García-Delgado; } \\
\text { Machuca; Medina } \\
\text { (2019) }\end{array}$ & $3.440,00$ & 26.000 .000 & Mocoa, Colômbia \\
\hline Esta tese & $44.760,39$ & $196.800,39$ & $\begin{array}{l}\text { Bacia Tingidor, Serra da Prata, Paraná, } \\
\text { Brasil }\end{array}$ \\
\hline Esta tese & $1.247,00$ & $237.673,00$ & $\begin{array}{l}\text { Bacia Guarda-mão I, Itaoca, São Paulo, } \\
\text { Brasil }\end{array}$ \\
\hline
\end{tabular}

Diferenças na topografia também podem ter influenciado na variação do $V_{a}$ nas bacias Tingidor e Guarda-mão I, como foi demonstrado pelo experimento de fluxo conduzido por Pirulli; Pastor (2012). Na Guarda-mão I, a topografia apresentou uma importância menor no runout em comparação a Tingidor, uma vez que o fluxo percorreu por um caminho quase estático até sofrer o desconfinamento e consequente deposição nas áreas mais planas do relevo, o que pode ter contribuído para uma maior estabilidade do processo de arrastamento e consequentemente maior $V_{t}$, apesar desta possuir um menor $V_{i}$.

Em contrapartida, na Tingidor, o confinamento e desconfinamento no decorrer do percurso de runout (P2 e P5) combinado ao menor comprimento do runout podem ter contribuído para uma redução na estabilidade do processo de arrastamento, resultando em um $V_{t}$ menor, apesar desta possuir um $V_{i}$ quase 30 vezes maior que a bacia Guarda-mão I.

As áreas apresentaram diferenças marcantes quanto às características climáticas e ao volume pluviométrico dos eventos, apesar de estarem localizadas no mesmo domínio geomorfológico (Serra do Mar que podem ser explicadas devido à sua localização específica). A bacia Tingidor, por estar localizada próxima a costa possui maior influência oceânica e orográfica (SILVA et al., 2015; TERASSI; GALVANI, 2017), enquanto a bacia Guarda-mão I está localizada na face continental da Serra, o que diminui a influência dos fatores citados. De acordo com Brito et al. (2017), o volume médio de chuva anual ao longo da face costeira da Serra do Mar no Rio de Janeiro pode exceder $2.750 \mathrm{~mm} / \mathrm{ano}$, enquanto ao longo da face continental da Serra do Mar os valores não chegam a $1.100 \mathrm{~mm} / \mathrm{ano}$, exatamente como demonstra a distribuição multianual das áreas aqui avaliadas. 
Os volumes pluviométricos obtidos para as áreas de estudo a partir do GPM também variaram, com o valor estimado acumulado de $\sim 176 \mathrm{~mm}$ para a bacia Tingidor (valor em acordo com outros reportados em eventos semelhantes), e de apenas $\sim 76 \mathrm{~mm}$ para a bacia Guarda-mão, muito abaixo do que é esperado para deflagração de corridas de detritos no Brasil.

Embora Brollo et al. (2015) e Gramani (2015) tenham estimado um volume de pelo menos $150 \mathrm{~mm}$ necessários para a deflagração do processo, a estação meteorológica mais próxima no centro urbano do município marcou apenas $18.6 \mathrm{~mm}$, semelhante aos valores captados pelo satélite da NASA. Outro ponto importante a ser avaliado são as características climáticas gerais da área. Embora o valor de $\sim 76 \mathrm{~mm}$ possa parecer pouco para a deflagração de corridas de detritos pensando no contexto da Serra do Mar, em especial na face costeira, este valor representa aproximadamente $1 / 3$ do valor total de chuva esperado para o mês inteiro de janeiro, de acordo com os dados pluviométricos. 


\subsection{Conclusões}

- Apesar de ambas as ocorrências terem sido deflagradas por escorregamentos devido à evento pluviométrico extremo na região da Serra do Mar, as corridas de detritos nas bacias Tingidor e Guarda-mão I apresentaram diferenças relacionadas a magnitude e dinâmica do processo. Chuvas intensas em março de 2011 ( 176 mm) contribuíram para a deflagração de 29 escorregamentos na Tingidor, dos quais ao menos 9 contribuíram com volume de material como fonte para as corridas e detritos deflagradas, com um $V_{i}$ de $\sim 44.000,00 \mathrm{~m}^{3}$ e um $\mathrm{V}_{\mathrm{a}}$ de $\sim 152.000,00 \mathrm{~m}^{3}$ contribuindo para o $\mathrm{V}_{\mathrm{t}}$ estimado em $\sim 196.800,39 \mathrm{~m}^{3}$. Comparativamente, um evento pluviométrico em fevereiro de 2014 na Guarda-mão I não tão intenso quanto na Tingidor ( 76 mm), contribuiu para a deflagração de 129 escorregamentos, dos quais apenas 1 contribuiu diretamente para iniciar a corrida de detritos, com um $V_{i}$ de $\sim 1.200 \mathrm{~m}^{3}$ e um $V_{a}$ de $236.426,00 \mathrm{~m}^{3}$ que resultou em um $V_{t}$ estimado de $\sim 237.000,00 \mathrm{~m}^{3}$.

- Os resultados mostram a importância do arrastamento no $V_{t}$ produzido por uma corrida de detritos, uma vez que a bacia Tingidor, apesar de possuir um $V_{i}$ maior que a bacia Guarda-mão I, não obteve um $V_{a}$ tão expressivo quanto a última para o $V_{t}$ da corrida de detritos. As diferenças geomorfológicas entre as duas bacias também influenciaram de forma significativa os resultados, como o comprimento de runout e amplitude altimétrica na Guarda-mão I. A zona de transporte foi menor na Tingidor, contribuindo para uma zona de deposição maior, cm contrapartida, a Guarda-mão I possui uma zona de transporte maior, que contribui para processo de arrastamento mais intenso, mas culmina em uma zona de deposição menor.

- As feições deposicionais na Guarda-mão I mostram uma visão geral do processo, com a presença de levees nas seções P2 e P3, na zona de transporte, e P7, após a deposição principal e estreitamento do canal. Blocos muito grandes estavam presentes apenas nas seções P5 e P6, que representam a deposição principal. Inversão granulométrica foi a feição mais frequente identificada. Em comparação, quase todas as seções na Tingidor estão localizadas na zona de deposição, que, combinado as características geomorfológicas, interfere em uma visão clara das diferenças entre feições em cada seção, com exceção das seções entre P3 e P5, que apresentaram maiores velocidades e pico de vazão e a presença de blocos muito grandes. A inversão granulométrica também foi a feição mais frequentemente identificada. 
- Ressalta-se a ausência de dados pluviométricos para as áreas estudadas considerando o volume deflagrado por hora, que seria o ideal para avaliar as características pluviométricas para a deflagração dos processos. 


\section{AVALIAÇÃO DA RELAÇÃO ENTRE MORFOMETRIA E O PROCESSO DE CORRIDAS DE DETRITOS}

Dada a natureza do processo de corridas de detritos e da sua relação intrínseca com a bacia hidrográfica, a avaliação das características morfométricas tornou-se uma etapa importante na análise da suscetibilidade. Determinadas características morfométricas de uma bacia podem influenciar em sua drenagem e escoamento, induzindo, assim, os processos que ocorrem em seu interior, tais como produção de sedimentos e a ocorrência de processos hidrogeomorfológicos, como corridas de detritos e enxurradas de detritos. Dessa forma, este capítulo visa contribuir para os estudos acerca da avaliação morfométrica e ocorrência de corridas de detritos no Brasil, como uma ferramenta a auxiliar na identificação e na determinação da suscetibilidade.

\section{1. Áreas de estudo}

Para esta avaliação, optou-se pela seleção de bacias sem ocorrência, localizadas em área suscetível, com o intuito de refinar as análises quanto às possíveis diferenças morfométricas entre as mesmas e suas implicações. Conforme exposto no Capítulo 4, as bacias Tingidor (Serra da Prata) e Guarda-mão I (Itaoca) foram selecionadas devido à ocorrência de corridas de detritos nos anos 2011 e 2014, respectivamente.

Localizadas em Itaoca, próximas à bacia Guarda-mão I, as bacias Gurutuba e Guardamão II foram selecionadas para avaliação. Uma vez que as bacias estão localizadas em uma área com características fisiográficas que a tornam suscetível a corridas de detritos, e não apresentaram ocorrência do processo na ocasião do evento de 2014 como a bacia Guarda-mão I, acredita-se que possíveis diferenças morfométricas entre as bacias possam ter contribuído para a não deflagração dos processos.

\footnotetext{
${ }^{7}$ Os resultados deste capítulo foram apresentados e submetidos para dois periódicos "Differences in the occurrence of debris flows in tropical and temperate environments: field observations and geomorphologic characteristics in Serra do Mar (Brazil) and British Columbia (Canada)", e "Parâmetros morfométricos e corridas de detritos: indice de suscetibilidade e magnitude para bacias hidrográficas na Serra do Mar".
} 


\subsection{Metodologia}

\subsubsection{Preparação da base de dados}

Para a extração dos dados básicos referentes ao relevo as cartas topográficas são a melhor referência disponível, no entanto, a sua disponibilidade em uma mesma escala para diferentes áreas tornou o seu uso inviável neste projeto. No caso, para o município de Itaoca, estão disponíveis cartas topográficas em escala 1:10.000, do Instituto Geográfico e Cartográfico (IGc), e 1:50.000, do IBGE; já para a região da Serra da Prata (PR) estão disponíveis cartas topográficas em escala 1:25.000, do ITCG, e 1:50.000, do IBGE.

Com relação à base de dados do IBGE, apesar de esta estar disponível para as duas áreas, a escala de pouco detalhe, em especial com relação à hidrografia, inviabilizou a sua utilização, sobretudo para a extração de parâmetros morfométricos. Apesar da disponibilidade de bases em maior detalhe, estas encontram-se em diferentes escalas, não sendo o ideal para a comparação de resultados, uma vez que podem ocorrer discrepâncias devido à diferença de escalas. Dessa forma, optou-se pela utilização do Modelo Digital de Elevação (MDE) ALOS PALSAR, com resolução de 12,5 metros.

O satélite japonês ALOS (Advanced Land Observing Satellite) dispõe de três instrumentos principais, dois ópticos, PRISM (Panchromatic Remote-sensing Instrument for Stereo Mapping) e AVNIR-2 (Advanced Visible and Near-Infrared Radiometer type 2); e um radar polarimétrico de abertura sintética de banda larga L PALSAR (Phased Array L-band Synthetic Aperture Radar). O radar PALSAR propicia a modificação do ângulo nadir de 9,7 para 50,8 graus. A resolução espacial obtida pelo nadir em 34,3 graus é 10 para o modo de maior resolução; já o sensor PRISM permite a obtenção de pares estereoscópios, dada à presença de três detectores posicionados em visadas distintas, a nadir (NADIR), a vante (FORWARD) e para trás (BACKWARD) (Figura 5.1). Possuindo resolução de 2,5 metros, o sensor PRISM possibilita a realização de mapeamento planialtimétrico na escala de 1:25.000 ou maior, no entanto, o MDE $A L O S$ só está disponível gratuitamente na resolução 12,5 metros, na Alaska Sattelite Facility (ASF), sendo uma derivação do SRTM (Shuttle Radar Topography Mission) de 30 metros com o objetivo de correção do terreno, não sendo um aprimoramento da qualidade ou da escala em si (ALASKA SATELLITE FACILITY, 2019; BARRA ROCHA et al., 2017; EGG et al., 2015; JAPAN AEROSPACE EXPLORATION AGENCY (JAXA) and EARTH OBSERVATION RESEARCH AND APPLICATION CENTER (EORC), 2008). 
Figura 5.1: Sensor PRISM - Modo de observação Triplet.

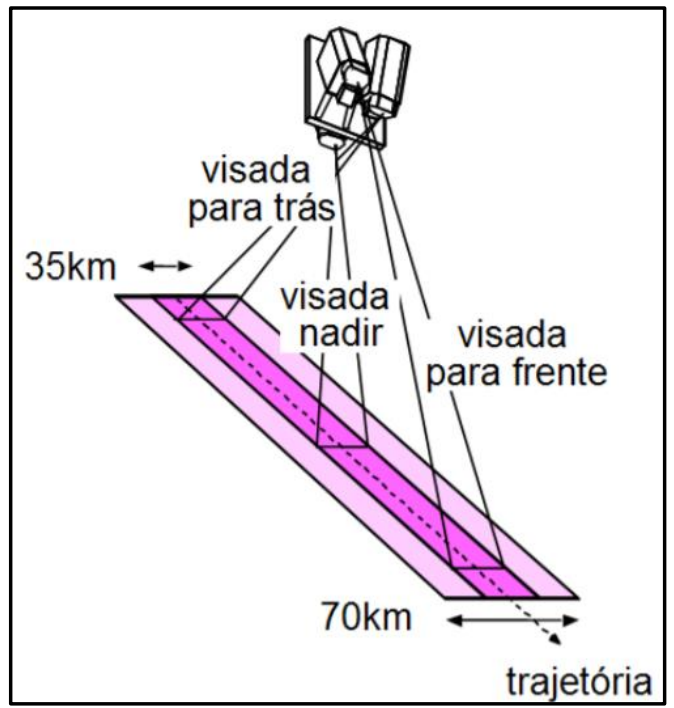

Fonte: IBGE (2009), modificado de EORC/JAXA (2007).

A extração da drenagem das bacias no MDE foi feita a partir do módulo Hydrology do ArcGIS 10.2, sendo realizados os procedimentos de verificação da presença de Sinks (I) e seu preenchimento com a função Fill (II), gerando, portanto, um raster com a direção dos fluxos de cada célula com a ferramenta Flow Direction (III); e criação de raster com o fluxo de acumulação com o Flow accumulation (IV). Em seguida, foi feita a álgebra de mapas para estipulação do limiar de extração da drenagem. Nesta etapa, foi estabelecido um limiar mínimo de pixels, considerado para formação da drenagem. Neste caso, optou-se pelo teste de vários limiares, utilizando como referência a drenagem disponível em escala 1:10.000 para Itaoca. Os testes indicaram o limiar $\geq 100,1$ como aquele cuja identificação das drenagens mais se aproximou da visualizada na carta do IGc. O mesmo limiar foi utilizado para definição das drenagens em todas as bacias. Após esta etapa, foi utilizada a ferramenta Stream to Feature para a transformação da drenagem em shapefile e a sua correção, utilizando como referência imagens do Google Earth georreferenciadas e ortofotos da Empresa Paulista de Planejamento Metropolitano S/A (EMPLASA), de 2010-2011, onde foram excluídas drenagens duplicadas e/ou inexistentes, e o endireitamento de alguns canais (Figura 5.2). 
Figura 5.2: Comparação entre drenagens de cartas topográficas (a e b) e drenagem extraída de MDE ALOS Palsar (c).

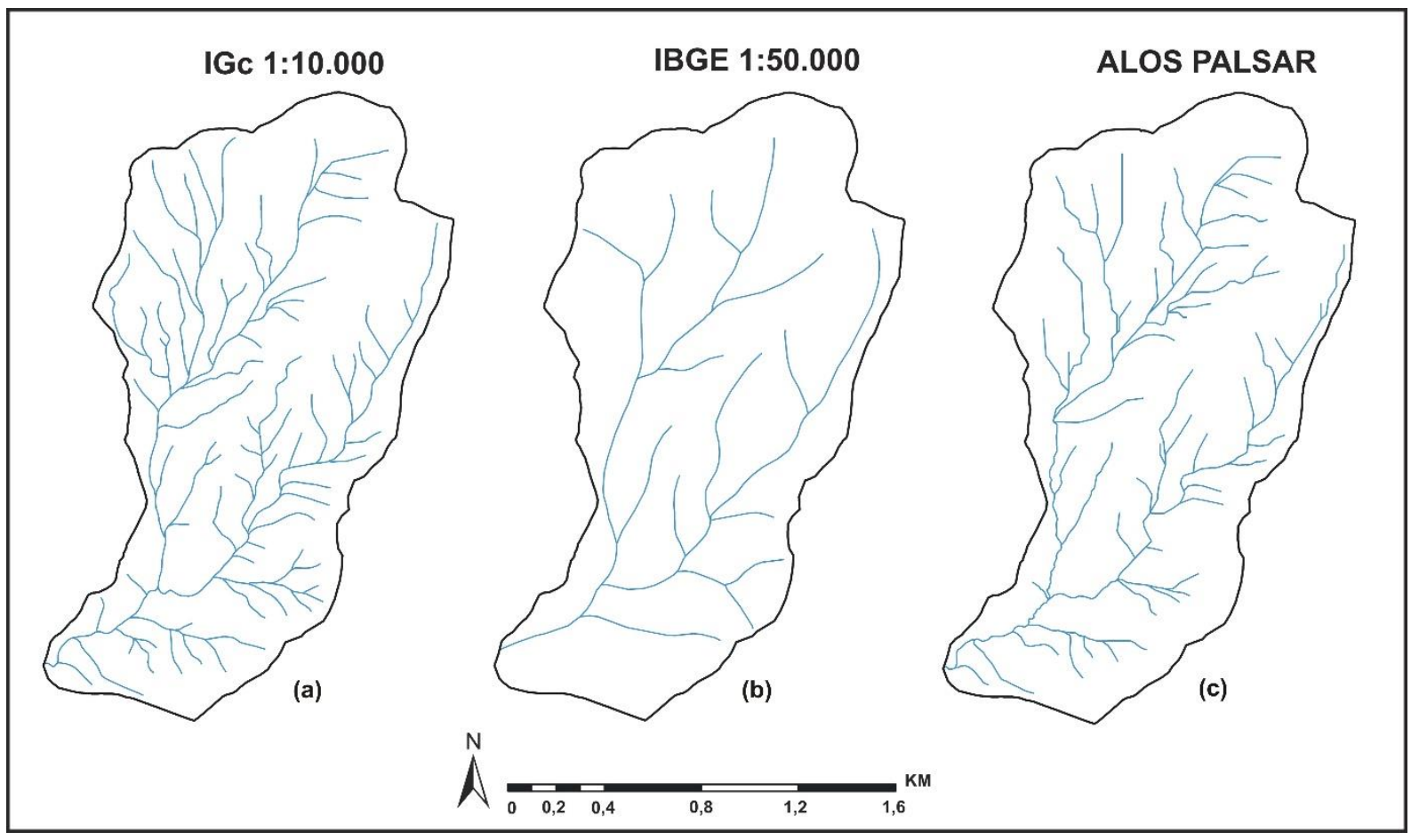

\subsubsection{Parâmetros morfométricos e análise estatística}

Utilizando parâmetros morfométricos, diversos aspectos das corridas de detritos podem ser avaliados, dentre eles avaliação da magnitude, estimativa de frequência, diferenciação de processos do tipo fluxo e avaliação de suscetibilidade de bacias hidrográficas. A avaliação das características morfométricas e sua relação com a ocorrência de corridas de detritos vêm sendo estudadas desde meados dos anos 1980, com destaque para pesquisas realizadas no hemisfério norte, em ambiente temperado (DE SCALLY; SLAYMAKER; OWENS, 2001; ILINCA, 2021; JAKOB， 1996; KOVANEN; SLAYMAKER, 2008; PORTILLA; CHEVALIER; HÜRLIMANN, 2010; VANDINE, 1985; WELSH; DAVIES, 2011; WILFORD et al., 2004; ZUBRYCKY et al., 2021) e ambiente tropical (AUGUSTO FILHO, 1993; CERRI et al., 2018; CHEN; YU, 2011; DIAS; VIEIRA; GRAMANI, 2016; GOMES, 2016; KANJI; GRAMANI, 2001; LIMA; FERNANDES; VARGAS JUNIOR, 2020; PICANÇO et al., 2016; VIEIRA et al., 1997).

A partir do MDE e da rede de drenagem foram mapeados os parâmetros morfométricos de Área $(A)$, Gradiente Altimétrico (Perfil Longitudinal) $(\Delta P l)$, Hierarquia de drenagem $(H d)$, Densidade de drenagem $(D d)$, Área $>25^{\circ}(A 25)$, Índice de rugosidade $(I r)$, Relação de relevo $(R r)$, Comprimento da bacia $(C b)$, Amplitude Altimétrica $(\Delta A)$ e Índice de Melton $(M)$, no software ArcGIS 10.2. (Tabela 5.1). 
Tabela 5.1: Parâmetros morfométricos mapeados.

\begin{tabular}{|c|c|c|}
\hline Parâmetros Morfométricos & Abreviação & Descrição \\
\hline Área & $A$ & Área planimétrica da bacia. \\
\hline $\begin{array}{r}\text { Gradiente Altimétrico (Perfil } \\
\text { Longitudinal) }\end{array}$ & $\Delta P l$ & $\begin{array}{l}\text { Variação altimétrica da área de iniciação da } \\
\text { corrida a partir do perfil longitudinal no canal } \\
\text { principal. }\end{array}$ \\
\hline Hierarquia de drenagem & $H d$ & $\begin{array}{l}\text { Quantificação dos canais na bacia a partir do } \\
\text { método de Shreve }(1966,1967) \text {. }\end{array}$ \\
\hline Densidade de drenagem & $D d$ & $\begin{array}{l}\text { Comprimento total dos canais dividido pela } \\
\text { área da bacia. }\end{array}$ \\
\hline Área $>25^{\circ}$ & $A 25$ & $\begin{array}{l}\text { Porcentagem de área da bacia com ângulo } \\
\text { maior que } 25^{\circ} \text {. }\end{array}$ \\
\hline Índice de rugosidade & $I r$ & $\begin{array}{l}\text { Amplitude altimétrica multiplicada pela } \\
\text { densidade de drenagem. }\end{array}$ \\
\hline Relação de relevo & $R r$ & $\begin{array}{l}\text { Amplitude altimétrica dividida pelo } \\
\text { comprimento da bacia. }\end{array}$ \\
\hline Comprimento da bacia & $\mathrm{Cb}$ & $\begin{array}{l}\text { Distância em linha reta da foz ao limite à } \\
\text { montante da bacia. }\end{array}$ \\
\hline Amplitude altimétrica & $\Delta A$ & $\begin{array}{l}\text { Relação entre a altitude máxima e altitude } \\
\text { mínima da bacia. }\end{array}$ \\
\hline Índice de Melton & $M$ & $\begin{array}{l}\text { Amplitude altimétrica dividida pela raiz } \\
\text { quadrada da área da bacia. }\end{array}$ \\
\hline
\end{tabular}

Após a obtenção de todos os parâmetros em ambiente SIG, foi realizada a análise estatística para avaliação da relação com a ocorrência de corridas de detritos. Inicialmente foi realizado o teste Shapiro-Wilk, visando avaliar a normalidade dos dados e então foi feita estatística descritiva e correlação, utilizando o coeficiente de correlação de Pearson (PEARSON, 1905; SHAPIRO; WILK, 1965). Em seguida, foi feita a plotagem dos parâmetros em boxplot para estabelecer um limiar no qual as corridas de detritos podem ocorrer com base nos resultados dos parâmetros, diferenciando as bacias com e sem ocorrência de corridas de detritos. 


\subsection{Resultados}

\subsubsection{Morfometria das bacias}

Os resultados indicam que, apesar de estarem de acordo com o esperado para bacias localizadas na região da Serra do Mar, os parâmetros morfométricos apresentaram variações (Tabela 5.2). Os parâmetros que apresentaram maior variação foram área da bacia (A), gradiente altimétrico $(\triangle P l)$, hierarquia de drenagem $(\mathrm{Hd})$, área acima de $25^{\circ}(\mathrm{A25})$, índice de rugosidade (Ir), amplitude altimétrica $(\Delta A)$ e índice de Melton (M).

Os valores para área da bacia (A) variaram de 2,02 e 4,52 km² (média de $3,2 \mathrm{~km}^{2}$ ). Ainda que consideradas bacias pequenas, e, neste sentido mais suscetíveis às corridas de detritos, tal variação associada à outras características morfométricas, podem reduzir a sua suscetibilidade.

O gradiente altimétrico $(\triangle P l)$ apresentou valores entre 224 e 352 m (média 302,5). Sendo as corridas de detritos induzidas pela gravidade, quanto maior o gradiente, maior o potencial de alcance do processo, podendo também influenciar em outras características, tais como transporte de materiais.

Tabela 5.2: Estatística descritiva geral dos parâmetros morfométricos.

\begin{tabular}{rccccc}
$\begin{array}{r}\text { Parâmetros } \\
\text { Morfométricos }\end{array}$ & Qnt. & Min. & Max. & Média & Desvio P. \\
\hline$A$ & 4 & 2,02 & 4,52 & 3,2 & 1,13 \\
$\Delta P l$ & 4 & 224 & 352 & 302,5 & 55,02 \\
$H d$ & 4 & 13 & 63 & 41 & 21,71 \\
$D d$ & 4 & 4,45 & 6,81 & 5,46 & 1,04 \\
$A 25$ & 4 & 18,51 & 33,5 & 26,87 & 7,75 \\
$I r$ & 4 & 1563,15 & 5203,75 & 3468,05 & 1494,19 \\
$R r$ & 4 & 0,20 & 0,25 & 0,22 & 0,02 \\
$C b$ & 4 & 2,63 & 3,49 & 3,15 & 0,36 \\
$\Delta A$ & 4 & 0,61 & 0,83 & 0,72 & 0,09 \\
$M$ & 4 & 0,33 & 0,58 & 0,42 & 0,11
\end{tabular}

Relacionados ao potencial de escoamento das bacias, os parâmetros de hierarquia de drenagem $(H d)$ e de densidade de drenagem $(D d)$ apresentaram resultados distintos. Enquanto a $H d$ apresentou uma variação expressiva, com valores entre 13 e 63 (média 41), a $D d$ apresentou pequena variação, com valores entre 4,45 e $6,81 \mathrm{~m} / \mathrm{km}^{2}$ (média 5,46). Semelhante à $H d$, o porcentual da área acima de $25^{\circ}$ (A25) também apresentou distinta variação, com valores entre 18,51 e 33,5 (média 26,87). 
Relacionados à rugosidade da bacia e ao seu potencial de produção de sedimentos, os parâmetros índice de rugosidade (Ir) e relação de relevo $(R r)$ mostraram resultados distintos. Enquanto Ir obteve expressiva variação, com valores entre 1563,15 e 5203,75 (média 3468,05), os valores de $R r$ foram próximos, entre 0,20 e 0,25 (média 0,22). De maneira análoga, forma semelhantes os valores do Comprimento da bacia $(\mathrm{Cb})$ também apresentaram pouca variação, com valores entre 2,63 e 3,49 (média 3,15).

Os parâmetros de Amplitude altimétrica $(\Delta A)$ e o Índice de Melton $(M)$ também variaram. Para $\Delta A$, entre 0,61 e 0,83 (média 0,72 ), representando pouco mais de $200 \mathrm{~m}$ de diferença entre o menor e o maior valor, e para $M$ variaram entre 0,33 e 0,58 (média 0,42). Ressalta-se que os valores mais altos de $M$ podem indicar bacias mais suscetíveis à determinados processos hidrogeomorfológicos, como corridas de detritos.

Os resultados mostraram 10 correlações fortes entre os parâmetros morfométricos, divididas entre 4 positivas e 6 negativas (Figura 5.3). Os parâmetros $A$ e $H d$ apresentaram o maior valor, com uma correlação positiva de 0.966, o que indica a tendência de aumento conjunto entre as variáveis, ou seja, o aumento de $A$ leva ao aumento de $H d$. Os parâmetros $A 25$ e $A, M$ e $R r$, e $R r$ e $\Delta P l$ também apresentam correlação positiva, $0.888,0.872$ e 0.807 , respectivamente.

Com relação às correlações negativas, os parâmetros $M$ e $H d$ apresentaram o maior valor, - 0.929. Mesma relação apresentada pelos parâmetros $\operatorname{Rr}$ e $H d, \operatorname{Rr}$ e $A, D d$ e $C b, \Delta A$ e $D d$, e $A$ e $M$, com correlação negativa de $-0.909,-0.904,-0.901,-0.820,-0.809$, respectivamente. 
Figura 5.3: Matrix de correlação entre os parâmetros morfométricos utilizando a correlação de Pearson. Na diagonal, encontra-se a curva de distribuição das variáveis. Na parte de baixo da curva de distribuição na diagonal encontram-se os gráficos de dispersão com linha de tendência. Na parte superior da curva de distribuição na diagonal encontram-se os valores das correlações. As correlações maiores que 0.800 (negativas ou positivas) estão destacadas, hieraquizadas e agrupadas por cores.

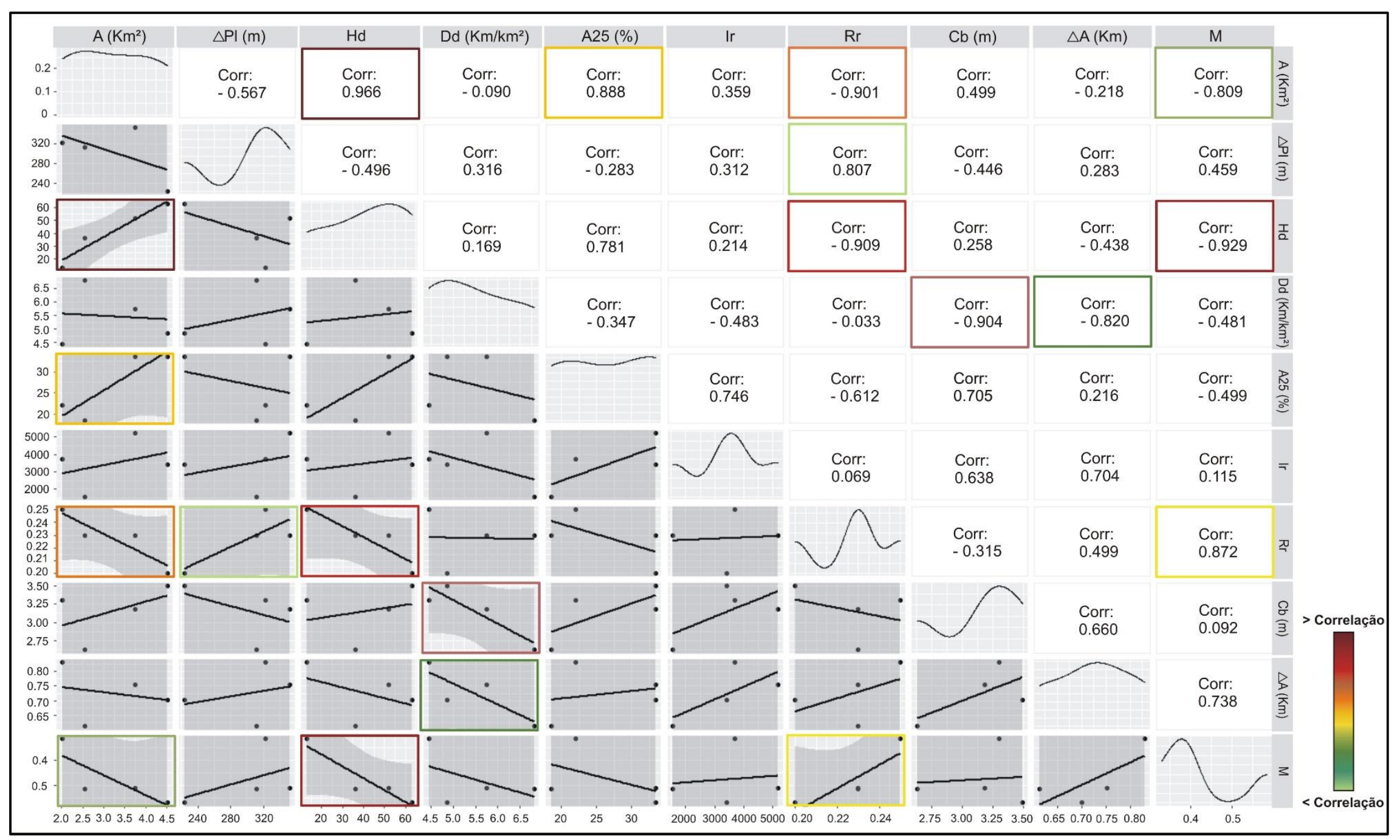




\subsubsection{Relação com a ocorrência de corridas de detritos}

A partir da avaliação específica dos resultados obtidos em cada uma das bacias, é possível entender as diferenças que podem ter contribuído para a ocorrência ou não de corridas de detritos (Tabela 5.3). Nesse sentido, alguns parâmetros apresentaram maior discrepância entre os valores, com destaque para $\Delta P l, I r, R r, \Delta A$ e $M$.

Com relação à $A$, apesar dos valores similares, as bacias com ocorrência de corridas de detritos apresentaram média menor do que as bacias sem ocorrência de corridas de detritos (Figura 5.4a). Independentemente de apresentarem uma variação pequena entre as bacias sem e com ocorrência, é possível observar que as bacias com ocorrência possuem maior $\Delta P l$ e menor variação. O valor médio também merece destaque, com média pouco abaixo de $340 \mathrm{~m}$ para as bacias com ocorrência e abaixo de $300 \mathrm{~m}$ para as bacias sem ocorrência (Figura 5.4b).

Tabela 5.3: Resultados dos parâmetros morfométricos específicados por bacias com e sem ocorrência de corridas de detritos.

\begin{tabular}{r|cccc}
\multirow{2}{*}{$\begin{array}{c}\text { Parâmetros } \\
\text { Morfométricos }\end{array}$} & \multicolumn{2}{|c|}{$\begin{array}{c}\text { Sem ocorrências } \\
\text { Guarda-mão }\end{array}$} & \multicolumn{2}{c}{ Com ocorrências } \\
\hline$A$ & Gurutuba & $\begin{array}{c}\text { Guarda-mão } \\
\text { I }\end{array}$ & Tingidor \\
$\Delta P l$ & 2,55 & 4,52 & 3,74 & 2,02 \\
$H d$ & 312 & 224 & 352 & 322 \\
$D d$ & 36 & 63 & 52 & 13 \\
$A 25$ & 18.81 & 4,86 & 5,75 & 4,45 \\
$I r$ & 1563,15 & 33.45 & 33.5 & 22.05 \\
$R r$ & 0,23 & 0,20 & 0,23 & 0,25 \\
$C b$ & 2,63 & 3,49 & 3,3 & 3,5 \\
$\Delta A$ & 0,613 & 0,701 & 0,753 & 0,83 \\
$M$ & 0,38 & 0,33 & 0,39 & 0,58
\end{tabular}

Os valores de $H d$ apresentaram diferenças quanto à média, com as bacias sem corridas com valor superior (36 e 63) às bacias com corridas (52 e 13). É possível verificar também que as bacias sem ocorrência possuem uma distribuição mais equilibrada, com menor variação entre mínima e máxima (Figura 5.4c). Os resultados de $D d$ seguem a mesma dinâmica, com as bacias sem ocorrência apresentando média maior, no entanto, as bacias com ocorrência apresentam distribuição mais equilibrada (Figura 5.4d). Com relação à $A 25$, apesar das bacias com ocorrência apresentarem maior média, a distribuição dos valores se mostrou semelhante em ambas (Figura 5.4e).

Os resultados para os parâmetros $I r, R r, C b, \Delta A$ e $M$ mostraram uma maior distinção entre as bacias. Para $I r$, apesar de ser considerado um valor alto para todas as áreas, a média 
para as bacias com ocorrência foi superior a 4000, com destaque para o valor da bacia Guardamão I $(5203,75)$. As bacias sem ocorrências, por outro lado, apresentaram média inferior a 3500,0 (Figura 5.4f).

$R r$ apresentou resultados semelhantes ao anterior, com os valores próximos para todas as bacias $(0,20-0,25)$. Apesar disso, as bacias com ocorrência mostraram uma distribuição dos dados com valor superior às bacias sem ocorrência (Figura 5.4g). Destacam-se aqui as bacias Tingidor (com ocorrência) e Gurutuba (sem ocorrência), que apresentaram a maior variação $(0,25$ e 0,20 , respectivamente). As bacias Guarda-mão I e II apresentaram o mesmo valor $(0,23)$, fato esse que pode ter sido influenciado por serem bacias "irmãs" ou contíguas, o que explica a sua semelhança com relação aos resultados de alguns parâmetros.

Com relação ao $C b$, os resultados foram semelhantes, com maior variação dos valores nas bacias sem ocorrência (2,63 e 3,49 km). As bacias com ocorrência apresentaram valores mais próximos $(3,3$ e 3,5 km) (Figura 5.4h). A $\Delta A$ obteve uma maior discrepância entre as bacias com e sem ocorrência (Figura 5.4i), com as primeiras apresentando maiores valores $(0,75$ e 0,83$)$. Os valores para as bacias sem ocorrência ficaram abaixo do menor valor para as com ocorrência $(0,70$ e 0,61), o que demonstra a maior suscetibilidade das áreas mais escarpadas e com maior variação altimétrica.

Por fim, os resultados para o $M$ também apresentaram maior variação entre as bacias, no entanto, as bacias com ocorrência mostraram maior variação dos valores $(0,39$ e 0,58), enquanto os valores para as bacias sem ocorrência foram mais próximos $(0,33$ e 0,38$)$ (Figura $\mathbf{5 . 4 j}$ ). Semelhantemente ao parâmetro $R r$, os valores para $M$ foram próximos para as bacias Guarda-mão I e II. 
Figura 5.4: Boxplot dos parâmetros morfométricos considerando bacias com ocorrência e sem ocorrência de corridas de detritos.

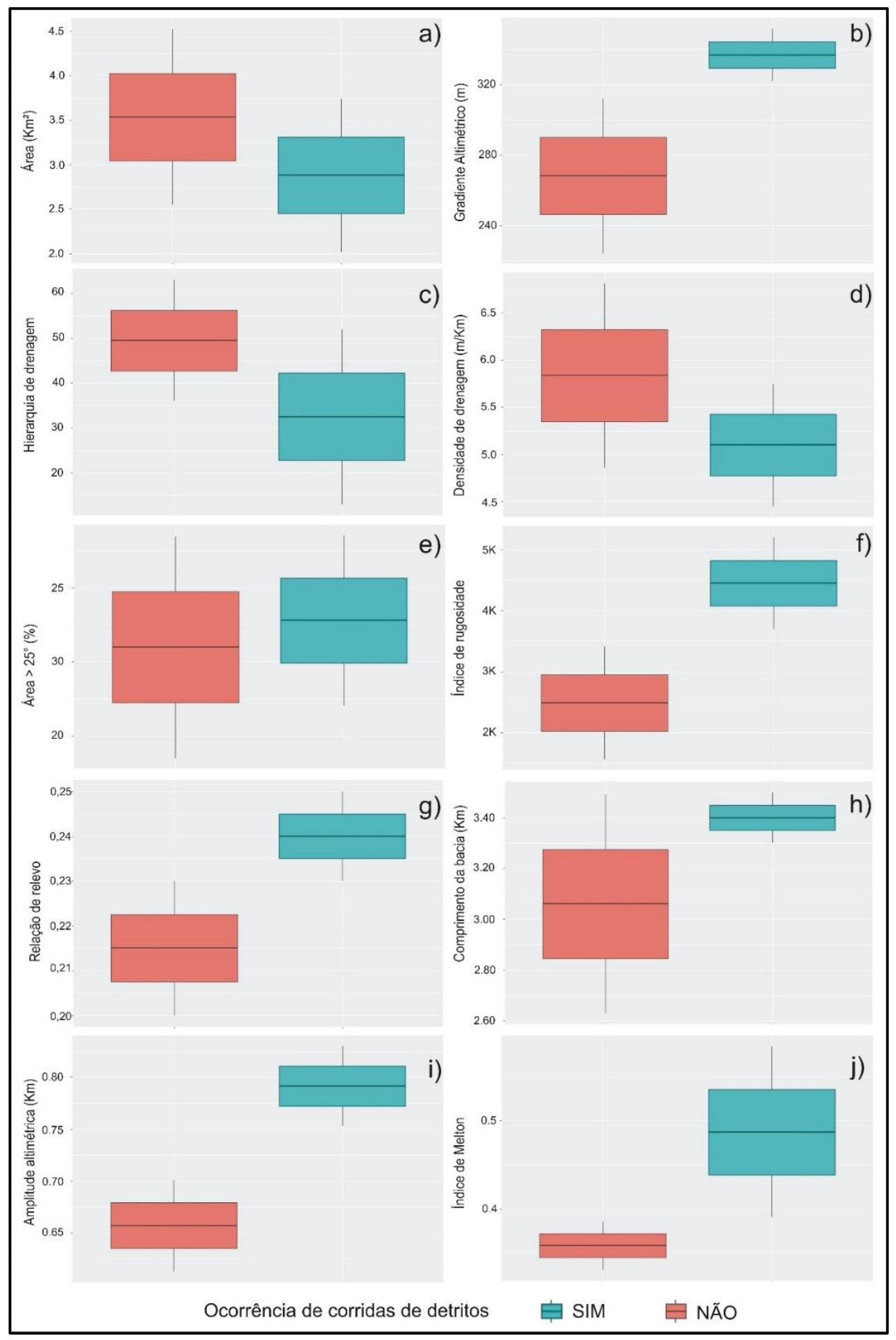




\subsubsection{Relação com a magnitude das ocorrências}

Conforme exposto no Capítulo 4, apesar dos valores semelhantes quanto ao volume e à magnitude final do processo de corridas de detritos, as bacias Tingidor e Guarda-mão I mostraram-se diferentes quanto ao desenvolvimento do processo. $\mathrm{O}$ processo na Tingidor se originou a partir de ao menos 9 escorregamentos nas encostas, dando origem à 3 fluxos que convergiram para a drenagem principal, com um elevado volume de sedimentos provindos dos escorregamentos na iniciação do processo (Figura 5.5). Em contrapartida, a corrida de detritos na bacia Guarda-mão I teve início a partir de um único escorregamento, já na drenagem principal da bacia, com um volume inicial menor (Figura 5.6). Apesar disso, o volume final estimado mobilizado foi maior na Guarda-mão I.

Figura 5.5: Resumo da ocorrência de corridas de detritos na bacia Tingidor.

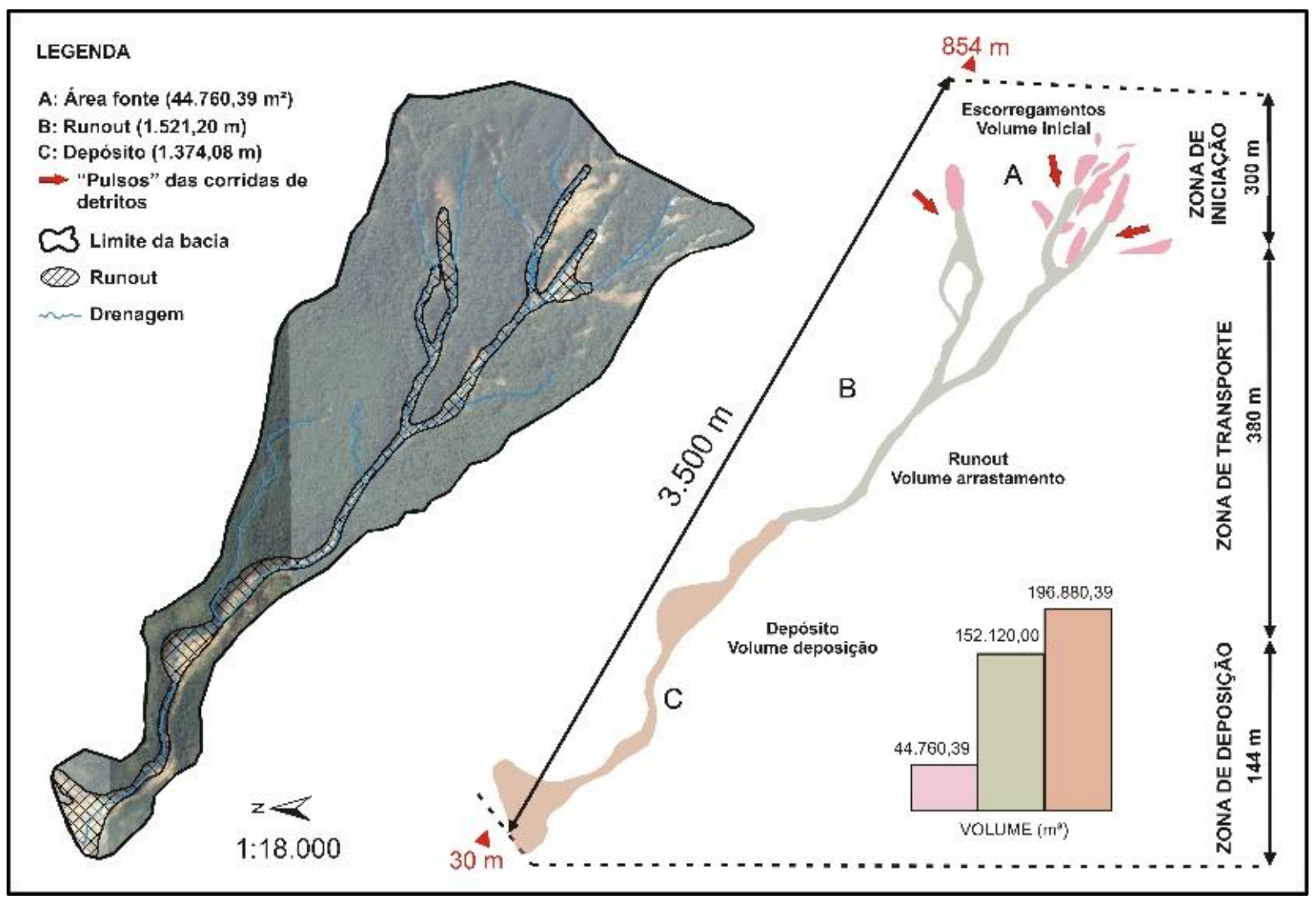


Figura 5.6: Resumo da ocorrência de corridas de detritos na bacia Guarda-mão I.

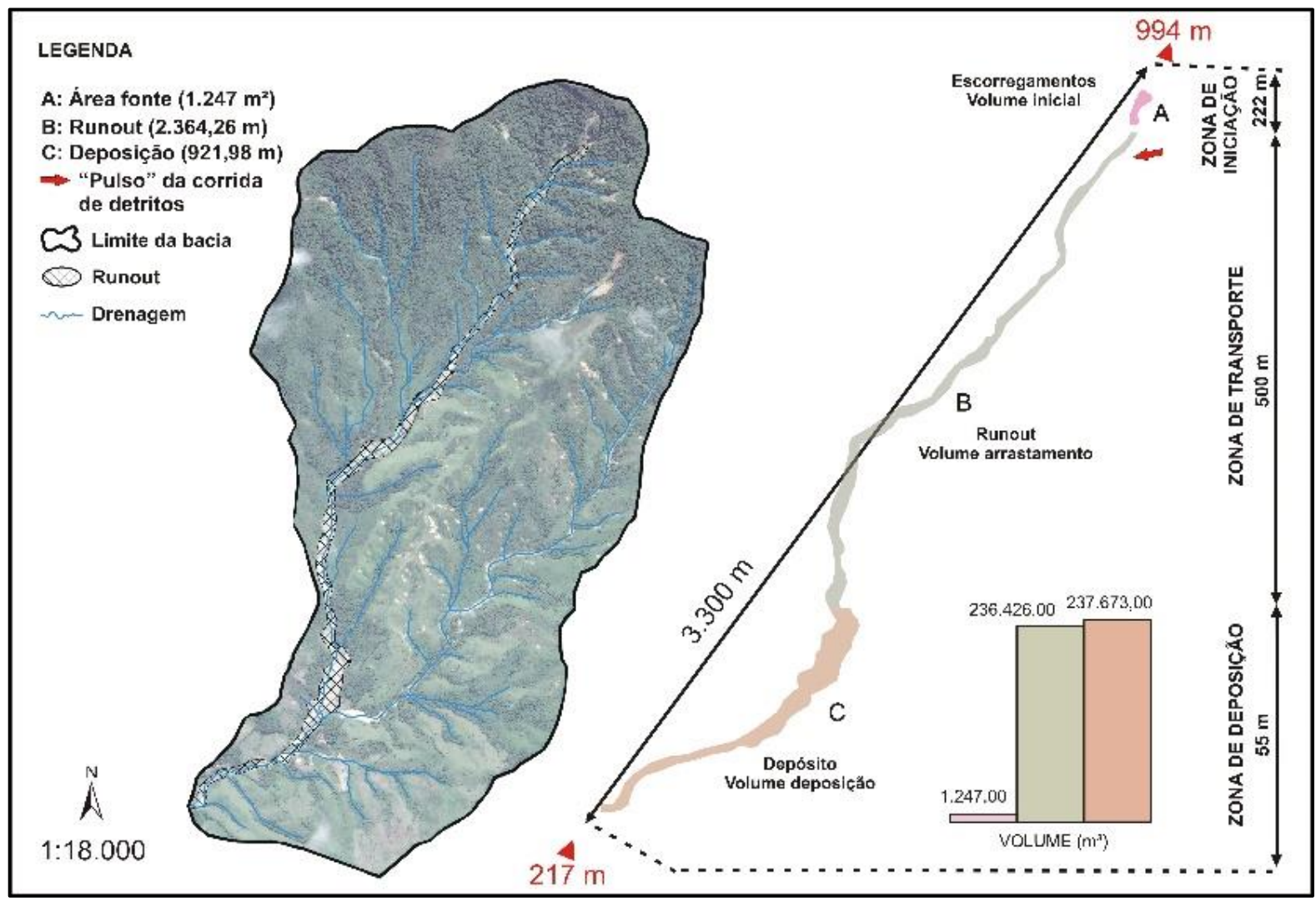

A bacia Guarda-mão I apresentou seis parâmetros com valores mais críticos: $A, \Delta P l$, $H d, D d, A 25$ e $I r$ e a bacia Tingidor apresentou quatro parâmetros com valores mais críticos, $\operatorname{Rr}, C b, \Delta A$ e $M$.

A partir dos resultados dos parâmetros nas bacias, foi possível identificar diferenças que podem ter contribuído para com a forma com que as corridas de detritos se desenvolveram, sobretudo, os $V_{t}$ produzidos. Apesar dos valores serem considerados elevados, os maiores valores em determinados parâmetros morfométricos podem ter contribuído para as especificidades do processo em cada bacia, considerando a suscetibilidade à ocorrência de corridas de detritos e das bacias terem apresentado processos semelhantes com relação à volume final e magnitude.

Os maiores valores para os parâmetros $\triangle P l$ e $A 25$ indicaram um maior gradiente da bacia Guarda-mão I, favorecendo a iniciação e transporte da corrida de detritos. O maior valor de $I r$ também indica que a bacia possui um maior potencial de geração de sedimentos. Tal conjuntura pode ter contribuído para a maior produção de sedimentos a partir do processo de arrastamento, uma vez que o fluxo possuiu um percurso contínuo e em amplo declive. Da mesma forma, os 
maiores valores para $A, H d$ e $D d$ contribuem para a maior intensidade dos processos hidrodinâmicos por favorecerem o escoamento e a ocorrência de cheias relampados na bacia.

Já com relação à bacia Tingidor, a $\Delta A$ e $C b$ podem ter contribuído para a iniciação e transporte da corrida de detritos, que neste caso, possuiu um volume inicial muito maior do que a bacia Guarda-mão I. Aqui, a produção de sedimentos por meio do processo de arrastamento foi menos expressiva do que na bacia Guarda-mão I, dada as diferenças geomorfológicas da bacia e iniciação em diferentes frentes, impedindo o fluxo de seguir um percurso contínuo até a área de deposição. Por sua vez, além de ser um indicador de rugosidade da bacia, a $R r$ também representa a variação altimétrica da bacia considerando o seu comprimento. Neste caso, o maior valor de $R r$ indica uma maior variação na bacia Tingidor, assim como potencial de produção de sedimentos. Por fim, o maior valor de $M$ indica as corridas de detritos como processo hidrogeomorfológico predominante na bacia. 


\subsection{Discussões}

A literatura destaca $A, R r, C b, \Delta A$ e $M$ como os parâmetros mais utilizados para a avaliação de áreas suscetíveis a ocorrência de corridas de detritos, em especial na América do Norte (Canadá e Estados Unidos), Europa (Alpes Italianos, Bulgária e Romênia), Ásia e Oceania (Taiwan e Nova Zelândia), com alguns estudos na América (Brasil e Porto Rico) (Tabela 5.4). Os resultados obtidos para as áreas com e sem ocorrência corridas de detritos estudadas nesta tese mostraram similaridade com os dados publicados de outras localidades (Figura 5.7).

Tabela 5.4: Parâmetros morfométricos mais utilizados para avaliação de áreas afetadas por corridas de detritos em diferentes áreas.

\begin{tabular}{|c|c|c|c|c|c|c|}
\hline Fonte & $\begin{array}{l}\text { Área } \\
\left(K m^{2}\right)\end{array}$ & $\begin{array}{l}\text { Relação de } \\
\text { relevo } \\
(\mathrm{m} / \mathrm{m})\end{array}$ & $\begin{array}{l}\text { Comprimento } \\
(\mathrm{Km})\end{array}$ & $\begin{array}{l}\text { Amplitude } \\
\text { altimétrica } \\
(\mathrm{Km})\end{array}$ & $\begin{array}{l}\text { Índice } \\
\text { de } \\
\text { Melton }\end{array}$ & Local \\
\hline $\begin{array}{r}\text { Jackson; } \\
\text { Kostaschuk; } \\
\text { Macdonald (1987) }\end{array}$ & ---- & ---- & ---- & ---- & $\begin{array}{c}0,25 \mathrm{a} \\
0,30\end{array}$ & $\begin{array}{l}\text { Alberta, } \\
\text { Canadá }\end{array}$ \\
\hline Slaymaker (1990) & 0,4 a 7 & ---- & ---- & ---- & ---- & $\begin{array}{l}\text { British } \\
\text { Columbia, } \\
\text { Canadá }\end{array}$ \\
\hline $\begin{array}{l}\text { Marchi; Pasuto; } \\
\text { Tecca (1993) }\end{array}$ & 0,20 a 14 & ---- & ---- & ---- & $\begin{array}{c}0,49 \mathrm{a} \\
1,74\end{array}$ & $\begin{array}{l}\text { Alpes } \\
\text { Italianos, Itália }\end{array}$ \\
\hline Jakob (1996) & 0,3 a 14,4 & 0,27 a 0,76 & ---- & 0,73 a 2,06 & ---- & $\begin{array}{l}\text { British } \\
\text { Columbia, } \\
\text { Canadá }\end{array}$ \\
\hline $\begin{array}{r}\text { Cenderelli and } \\
\text { Steven Kite (1998) }\end{array}$ & $\begin{array}{l}1,78 \mathrm{a} \\
17,47\end{array}$ & 0,35 a 0,49 & 1 a 4,28 & ---- & ---- & $\begin{array}{l}\text { Montanha } \\
\text { North Fork, } \\
\text { USA }\end{array}$ \\
\hline $\begin{array}{r}\text { De Scally; } \\
\text { Slaymaker; Owens } \\
\text { (2001) }\end{array}$ & $\begin{array}{c}0,05 \mathrm{a} \\
10,90\end{array}$ & ---- & ---- & 0,31 a 1,36 & $\begin{array}{c}0,38 \mathrm{a} \\
1,77\end{array}$ & $\begin{array}{l}\text { British } \\
\text { Columbia, } \\
\text { Canadá }\end{array}$ \\
\hline $\begin{array}{r}\text { Marchi; Arattano; } \\
\text { Deganutti (2002) }\end{array}$ & 4,1 & ---- & ---- & 1,15 & ---- & $\begin{array}{l}\text { Alpes } \\
\text { Italianos, Itália }\end{array}$ \\
\hline Wilford et al. (2004) & 0,2 a 4,1 & 0,3 a 0,49 & 0,28 a 4,68 & 0,6 a 1,4 & $\begin{array}{c}0,66 \mathrm{a} \\
1,21\end{array}$ & $\begin{array}{l}\text { British } \\
\text { Columbia, } \\
\text { Canadá }\end{array}$ \\
\hline $\begin{array}{r}\text { Gabet and Bookter, } \\
(2008)\end{array}$ & $\begin{array}{c}0,08 \mathrm{a} \\
0,76\end{array}$ & ---- & ---- & ---- & ---- & $\begin{array}{l}\text { Montana, } \\
\text { USA }\end{array}$ \\
\hline $\begin{array}{r}\text { Kovanen and } \\
\text { Slaymaker (2008) }\end{array}$ & $\begin{array}{c}0,29 \mathrm{a} \\
32,9\end{array}$ & 0,01 a 0,58 & & 0,58 a 1,2 & $\begin{array}{c}0,15 \mathrm{a} \\
1,07\end{array}$ & $\begin{array}{l}\text { North } \\
\text { Cascades } \\
\text { foothill, USA }\end{array}$ \\
\hline $\begin{array}{r}\text { De Scally; Owens; } \\
\text { Louis (2010) }\end{array}$ & $\begin{array}{c}0,18 \mathrm{a} \\
9,66\end{array}$ & 0,25 a 0,88 & 1,05 a 4,5 & 0,55 a 1,93 & $\begin{array}{c}0,45 \mathrm{a} \\
1,59\end{array}$ & Nova Zelândia \\
\hline $\begin{array}{l}\text { Portilla; Chevalier; } \\
\text { Hürlimann (2010) }\end{array}$ & $\begin{array}{c}0,029 \mathrm{a} \\
3,76\end{array}$ & 0,22 a 0,51 & ---- & 0,29 a 1,42 & $\begin{array}{c}0,45 \mathrm{a} \\
2,91\end{array}$ & $\begin{array}{l}\text { Montanha dos } \\
\text { Pirenéus, Itália }\end{array}$ \\
\hline $\begin{array}{r}\text { Welsh and Davies } \\
\text { (2011) }\end{array}$ & ---- & ---- & $<2,7$ & ---- & $>0,60$ & Nova Zelândia \\
\hline Chen; Yu (2011) & $\begin{array}{c}0,51 \mathrm{a} \\
8,63\end{array}$ & 0,20 a 0,44 & 1,54 a 5,75 & ---- & ---- & Taiwan \\
\hline
\end{tabular}




\begin{tabular}{|c|c|c|c|c|c|c|}
\hline $\begin{array}{r}\text { Simoni; Mammoliti; } \\
\text { Berti (2011) }\end{array}$ & $\begin{array}{c}0,28 \mathrm{a} \\
9,40\end{array}$ & --- & 0,9 a 3,9 & --- & ---- & $\begin{array}{l}\text { Tirol do Sul, } \\
\text { Itália }\end{array}$ \\
\hline $\begin{array}{r}\text { Dias; Vieira; } \\
\text { Gramani (2016) }\end{array}$ & 24 e 20 & 0,07 e 0,13 & --- & ---- & --- & $\begin{array}{l}\text { Serra do Mar, } \\
\text { Brasil }\end{array}$ \\
\hline Picanço et al. (2016) & $\begin{array}{c}1,03 \mathrm{a} \\
3,06\end{array}$ & ---- & 1,99 a 3,71 & 0,66 a 1,11 & $\begin{array}{c}0,41 \mathrm{a} \\
0,78\end{array}$ & $\begin{array}{l}\text { Serra do Mar, } \\
\text { Brasil }\end{array}$ \\
\hline $\begin{array}{r}\text { Dotseva and } \\
\text { Gerdjikov (2020) }\end{array}$ & $\begin{array}{l}1,52 \mathrm{a} \\
3,76\end{array}$ & 0,05 a 0,68 & ---- & ---- & $\begin{array}{c}0,54 \mathrm{a} \\
0,73\end{array}$ & $\begin{array}{l}\text { Montanhas } \\
\text { Stara Platina, } \\
\text { Bulgária }\end{array}$ \\
\hline $\begin{array}{r}\text { Nikolova; } \\
\text { Kamburov; Rizova } \\
\text { (2020) }\end{array}$ & $\begin{array}{c}0,015 \mathrm{a} \\
39,27\end{array}$ & 0,05 a 0,68 & 0,33 a 15,50 & 0,16 a 0,82 & $\begin{array}{c}0,13 \mathrm{a} \\
1,59\end{array}$ & $\begin{array}{l}\text { Rhodopes } \\
\text { oriental, } \\
\text { Bulgária }\end{array}$ \\
\hline Ilinca (2021) & $\begin{array}{c}0,005 \text { a } \\
1,02\end{array}$ & Média 0,56 & $<1,7$ & ---- & $>0,55$ & $\begin{array}{l}\text { Cárpatos do } \\
\text { Sul, Romênia }\end{array}$ \\
\hline Coe et al. (2021) & $\begin{array}{c}0,094 \mathrm{a} \\
0,25\end{array}$ & ---- & ---- & 0,13 a 0,25 & $\begin{array}{c}0,53 \mathrm{a} \\
0,87\end{array}$ & Porto Rico \\
\hline Dias et al. (2021) & ---- & 0,07 a 0,11 & ---- & ---- & --- & $\begin{array}{l}\text { Serra do Mar, } \\
\text { Brasil }\end{array}$ \\
\hline Esta tese & $\begin{array}{l}2,02 \mathrm{e} \\
3,74\end{array}$ & 0,23 e 0,25 & 3,3 e 3,5 & 0,75 e 0,83 & $\begin{array}{c}0,39 \mathrm{e} \\
0,58\end{array}$ & $\begin{array}{l}\text { Serra do Mar, } \\
\text { Brasil }\end{array}$ \\
\hline
\end{tabular}

Figura 5.7: Boxplot dos parâmetros da Tabela 5.4 categorizado por continente.

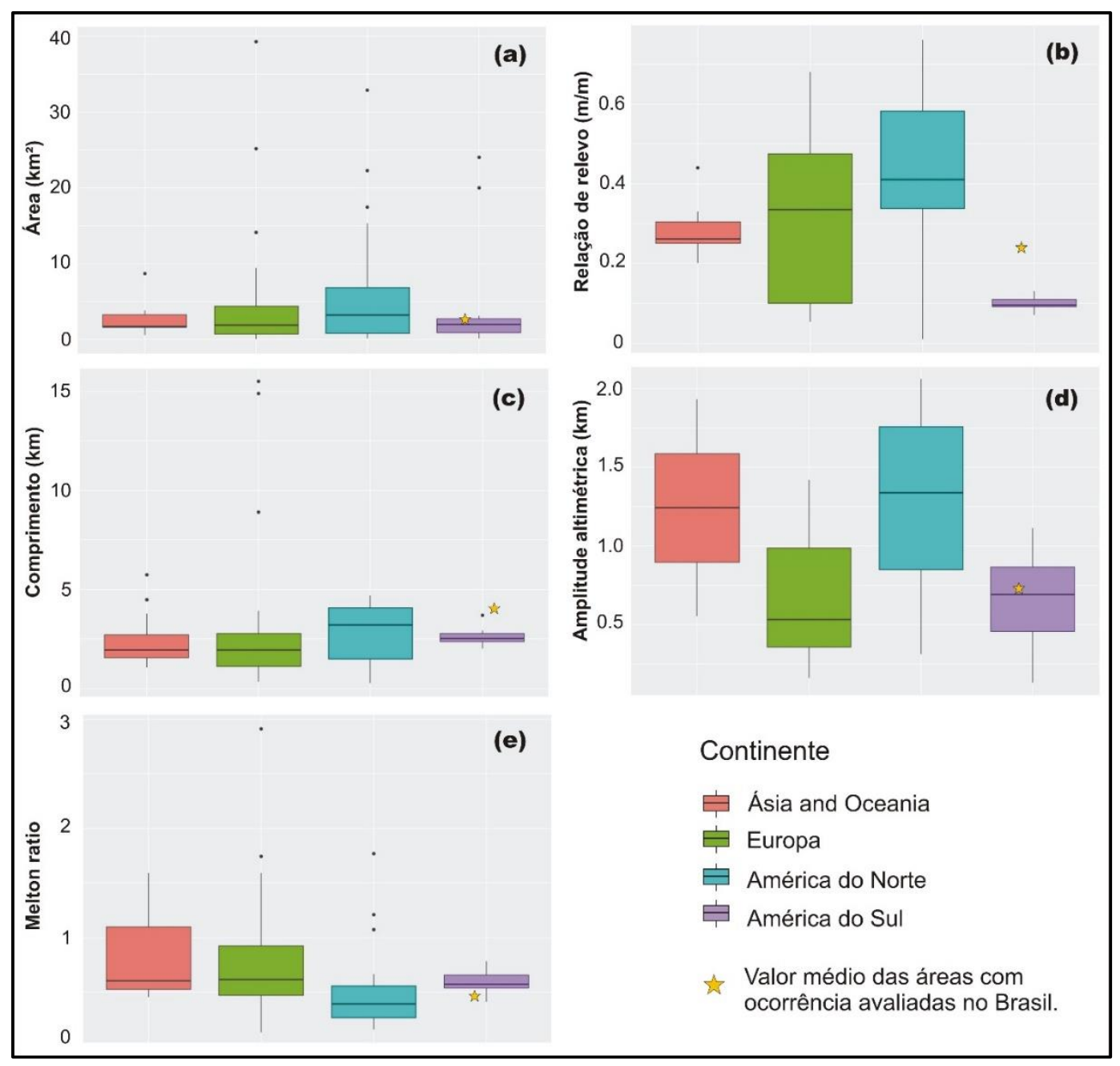


O parâmetro $A$ é indicado como um dos mais importantes na avaliação de corridas de detritos. De acordo com Slaymaker (1990), as corridas de detritos tendem a ocorrer em bacias pequenas, com até $10 \mathrm{~km}^{2}$. No entanto, os valores para ocorrência na América do Norte, Europa, América do Sul e Ásia possuem uma maior amplitude, variando entre 0,005 e 32,9 km² (Tabela 5.4). Os resultados para $A$ nas bacias com ocorrência estão dentro desta variação $(2,02$ e 3,74$)$, assim como os resultados para as bacias sem ocorrência $(2,55$ e 4,52).

Considerando as áreas afetadas por corridas na América do Sul, o valor médio das bacias Guarda-mão I e Tingidor está acima da mediana (Figura 5.7a). Diferenças relacionadas à intensidade das corridas de detritos podem estar associadas ao tamanho das bacias. Apesar de bacias pequenas serem consideradas mais suscetíveis, conforme apontado por Slaymaker (1990), a intensidade do processo pode variar dependendo do tamanho da bacia, e, como relatado por Ilinca (2021), bacias maiores estão mais sujeitas à ocorrência de enxurradas de detritos.

Destaca-se aqui a bacia Guarda-mão I, onde o processo se iniciou como corrida de detritos, mas após a deposição inicial, tornou-se uma enxurrada de detritos, seguido na planície e destruindo o centro urbano da cidade de Itaoca. Com relação à áreas afetadas em outras localidades, os valores das bacias no Brasil se mostraram semelhantes aos encontrados na Europa, nas Montanhas dos Pirineus, na Itália, com valores entre 0,029 a 8,2 km² (PORTILLA; CHEVALIER; HÜRLIMANN, 2010), e nas Montanhas Stara Platina, na Bulgária, com valores entre 1,52 e 3,76 km² (DOTSEVA; GERDJIKOV, 2020); na América do Norte, em Howe Sound, Columbia Britânica, com valores entre 0,4 e 7 km² (SLAYMAKER, 1990), e na América do Sul, na Serra do Mar, Brasil, com valores 1,03 e 3,06 (PICANÇO et al., 2016).

Considerando os resultados de diferentes áreas, $R r$ variou entre 0,01 e 0,88 (Tabela 5.4). As áreas estudadas apresentaram valores próximos, sendo 0,23 e 0,25 para Guarda-mão I e Tingidor, respectivamente (com ocorrências) e 0,23 e 0,20 para Guarda-mão II e Gurutuba, respectivamente (sem ocorrências). Em comparação às áreas afetadas considerando a localização (continente), no Brasil apresentaram média superior aos valores encontrados na América do Sul e menor em comparação à América do Norte e Ásia e Oceania, estando pouco abaixo da mediana para os dados referentes as áreas na Europa (Figura 5.7b). Nesse sentido, os valores encontrados nas bacias Guarda-mão I e Tingidor possuem maior similaridade com os encontrados em áreas afetadas na Europa.

Na Columbia Britânica, Canadá, Jakob (1996) encontrou variação entre os valores de $R r$ para bacias "weathering-limited" (limitadas pelo intemperismo), e bacias "transport-limited" (limitadas pelo transporte). Apesar de apresentarem valores médios e máximos parecidos, os 
valores mínimos para as áreas limitadas pelo intemperismo foram menores em comparação às áreas limitadas pelo transporte $(0,27$ contra 0,38 , respectivamente). Para o autor, bacias limitadas pelo transporte possuem uma maior disponibilidade de sedimentos, contribuindo para uma maior recorrência de ocorrências de corridas de detritos comparado às bacias limitadas pelo intemperismo (Figura 5.8). Nesse, as bacias Guarda-mão I e Tingidor poderiam ser consideradas limitadas pelo intemperismo, dado ao valor de $R r$ e baixa recorrência de eventos em comparação à outras localidades.

Figura 5.8: Diferença entre bacias com suprimento limitado (Sistema limitado pelo intemperismo) e ilimitado (Sistema limitado pelo transporte) de sedimentos e relação com ocorrência de corridas de detritos.

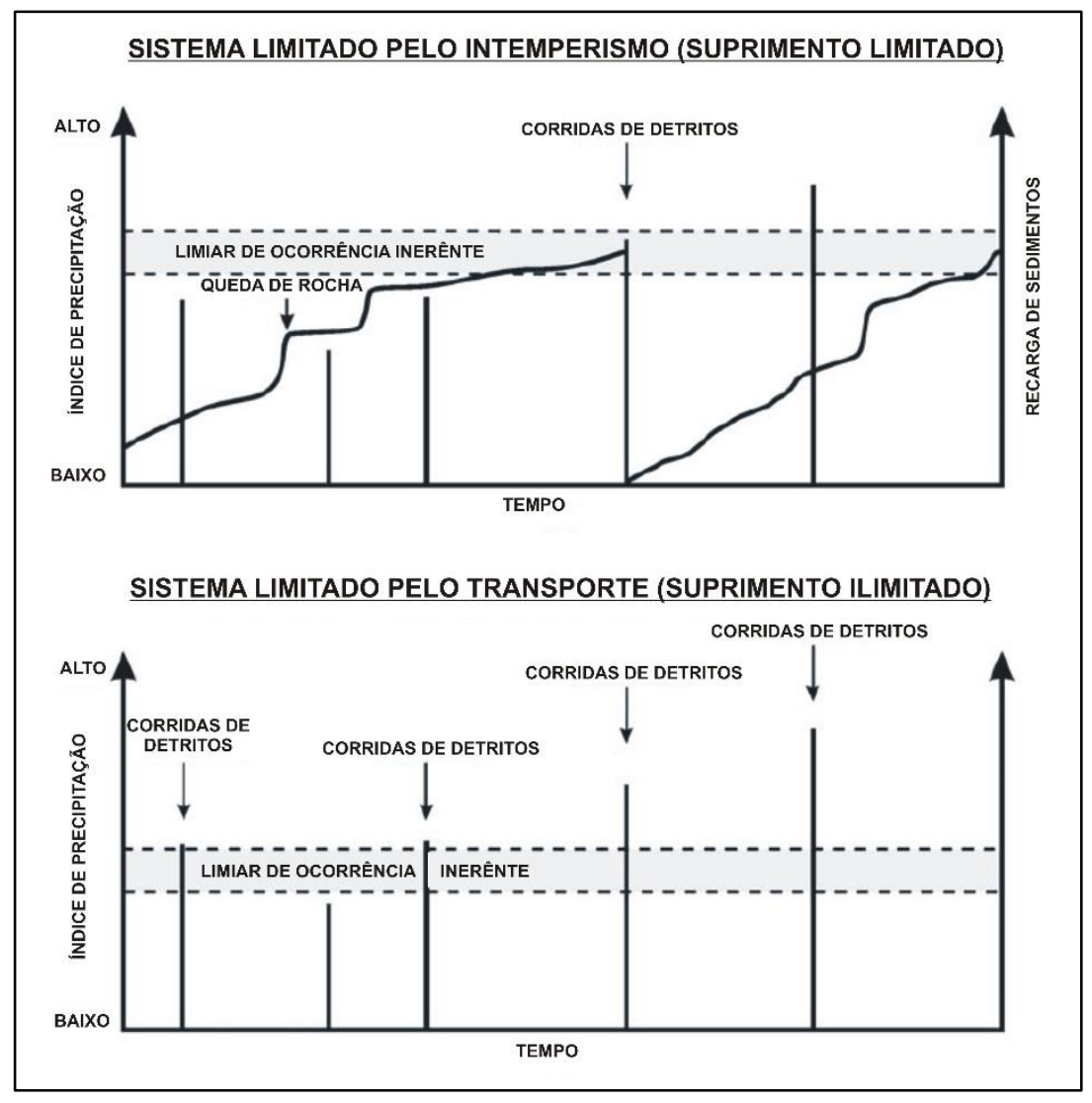

Fonte: Modificado de Jakob (1996).

O parâmetro $C b$ vem sendo utilizado recentemente para a indicação de áreas com predomínio de ocorrência de corridas de detritos. De acordo com Welsh; Davies (2011), tais áreas tendem a possuir o comprimento máximo de $2,7 \mathrm{~km}$, estando assim, as áreas afetadas no Brasil acima desse limite $(3,5$ e 3,3 km). Apenas a bacia Guarda-mão II, que não possui ocorrência, apresentou valor dentro do limiar proposto por Welsh; Davies (2011) (2,63 km). Valores acima de 2,7 km foram encontrados em diferentes áreas com ocorrência de corridas de 
detritos, onde $C b$ variou entre 0,28 e $15,50 \mathrm{~km}$ (Tabela 5.4). Cenderelli; Steven Kite (1998) encontraram valores entre 1,0 e 4,28 km na Montanha North Fork, nos Estados Unidos; na região da Columbia Britânica, no Canadá, Wilford et al. (2004) encontraram valores semelhantes, entre 0,28 e 4,68 km, assim como De Scally; Owens; Louis (2010) na Nova Zelândia, com valores entre 1,05 e 4,5 km. Já em Taiwan, Chen; Yu (2011) encontraram valores um pouco maiores, entre 1,54 e $5,75 \mathrm{~km}$.

$\mathrm{Na}$ Europa os valores apresentaram maiores variações em comparação às áreas na América do Norte. Em Tirol do Sul, Itália, Simoni; Mammoliti; Berti (2011) encontraram valores entre 0,9 e 3,9 km, próximos aos valores encontrados nas áreas com ocorrência no Brasil, enquanto Nikolova; Kamburov; Rizova (2020), na Bulgária, os valores variaram um pouco mais, entre 0,33 e 15,50 km. Na América do Sul, Picanço et al. (2016) identificaram valores entre 1,99 e 3,71 para bacias afetadas na Serra do Mar. Considerando a categorização por continente (Figura 5.7c), os valores para a Tingidor e Guarda-mão I estão acima dos encontrados para outras áreas na América do Sul, aparecendo como outliners na distribuição. No entanto, os valores estão dentro da distribuição para as áreas na América do Norte e na Europa.

A $\Delta A$ variou entre 0,13 e $2,13 \mathrm{~km}$ (Tabela 5.4) e os valores categorizados por continente apresentaram significativa variação em sua distribuição. Os valores para Ásia e Oceania foram semelhantes com a distribuição para América do Norte (predomínio de valores $>1,0 \mathrm{~km}$ ), enquanto na Europa os valores foram mais semelhantes à da América do Sul (predomínio de valores $<1,0 \mathrm{~km})$. Nesse sentido, os valores obtidos nas bacias Tingidor e Guarda-mão I (0,83 e 0,75 km, respectivamente) apresentaram maior semelhança com os resultados de áreas avaliadas na Europa, estando dentro da distribuição dos dados para América do Sul (Figura 5.7d).

Destacam-se os valores apresentados por Nikolova; Kamburov; Rizova (2020) (0,16 a $0,82 \mathrm{~km}$ ), semelhantes aos valores encontrados por Coe et al. (2021) e Picanço et al. (2016) para áreas na América do Sul (entre 0,13 e 0,25 e entre 0,66 a 1,11, respectivamente). As áreas sem ocorrência (Gurutuba e Guarda-mão II) apresentaram valores até 0,7 km, observados também em áreas com ocorrência em diferentes continentes.

De acordo com Welsh; Davies (2011), valores > 0.60 indicam bacias com predominância de corridas de detritos, enquanto <0,60 e > 0,30 indicam bacias com predomínio de enxurradas de detritos e enxurradas. Valores < 0,30 indicam bacias com predomínio de processos fluviais. Resultados em diferentes partes do mundo mostram uma variação nesses valores para áreas com ocorrência de corridas de detritos, entre 0,13 e 2,91 (Tabela 5.4). Com 
relação as bacias com ocorrência e sem ocorrência, os resultados variaram, sendo o valore mais baixo para aquelas sem ocorrência (Gurutuba, 0,33), e mais alto em uma bacia com ocorrência (Tingidor, 0,58).

As bacias Guarda-mão I e II apresentaram valores semelhantes: 0,39 e 0,38, respectivamente. Valores abaixo do limiar proposto por Welsh; Davies (2011) podem ser observados em diferentes áreas. De Scally; Slaymaker; Owens (2001) encontraram valores entre 0,38 e 1,77 para bacias afetadas na Columbia Britânica, Canadá. Já Kovanen; Slaymaker (2008) encontraram valores menores (entre 0,15 e 1,07) para áreas avaliadas em North Cascades foothill, em Washington (EUA), semelhante aqueles observados por Nikolova; Kamburov; Rizova (2020): 0,13 e 1,59.

Em comparação à outras áreas na Europa, América do Sul e na Ásia e Oceania, os valores de $M$ se mantiveram acima de 0,45, porém ainda abaixo do limiar indicado por Welsh; Davies (2011). Nas Montanhas dos Pirenéus, Itália, Portilla; Chevalier; Hürlimann (2010) encontraram valores entre 0,45 e 2,91, valores próximos aos encontrados por De Scally; Owens; Louis (2010) na Nova Zelândia (entre 0,45 a 1,59). Na Romênia, Ilinca (2021) encontrou valores > 0,55 para áreas afetadas por corridas de detritos; semelhantes aos encontrados por Dotseva; Gerdjikov (2020) na Bulgária, com valores entre 0,54 e 0,73 e por Coe et al. (2021) em Porto Rico, e por Picanço et al. (2016) na Serra do Mar, Brasil, com valores entre 0,53 e 0,87 e entre 0,41 a 0,78, respectivamente. Considerando a categorização por continente (Figura 5.7e) a média dos valores para as bacias Tingidor e Guarda-mão I próximo ao valor mínimo para as áreas na América do Sul, acima da mediana para os valores encontrados na América do Norte, e abaixo da mediana para os valores encontrados na Europa.

Os parâmetros $\Delta P l, H d, D d, A 25$ e $I r$ são menos utilizados na literatura na avaliação de bacias afetadas por corridas de detritos, no entanto, os resultados apresentaram diferenças considerando áreas com ocorrência e sem ocorrência que podem explicar a maior e menor suscetibilidade das áreas ao processo.

As bacias Tingidor e Guarda-mão I apresentaram valores maiores que as bacias Gurutuba e Guarda-mão II para $\Delta P l$ (322 e 352 metros contra 224 e 312 metros, respectivamente). Já com relação à $A 25$, apesar de próximos, os valores variaram entre as bacias com ocorrência (33,5 e 22,05 \% para as bacias Guarda-mão I e Tingidor, respectivamente) e sem ocorrência (18,51 e 33,3 \% para as bacias Guarda-mão II e Gurutuba, respectivamente). Nikolova; Kamburov; Rizova (2020) utilizou como parâmetro a porcentagem de área da bacia acima de $30^{\circ}$ e $45^{\circ}$, encontrando valores entre $1,28 \%$ e 74,14\%. Da mesma forma, Coe et al. (2021) utilizaram o valor de $30^{\circ}$, obtendo valores entre $54 \%$ e $62 \%$. Esta variabilidade entre os 
resultados pode indicar a influência de outros parâmetros morfométricos no controle das ocorrências de corridas de detritos na bacia, como, por exemplo, os maiores valores de $\Delta P l$ nas bacias com ocorrência.

Para $D d$, os resultados indicam que todas as bacias possuem uma boa capacidade de escoamento e drenagem. Já para $H d$, apenas a bacia Tingidor (com ocorrência) apresentou um valor baixo (13) em comparação às demais bacias (de 36 a 52), com a bacia Gurutuba (sem ocorrência) apresentando o maior valor.

Jakob (1996) encontrou valores de $D d$ entre 0,6 e $6,8 \mathrm{~km} / \mathrm{km}^{2}$ para bacia limitadas pelo intemperismo e entre 2,1 e $7,4 \mathrm{~km} / \mathrm{km}^{2}$ para bacias limitadas pelo transporte. Já Cenderelli; Steven Kite (1998) dividiram as bacias de acordo com as zonas referentes ao processo de corrida de detritos, e encontraram valores mais altos para a $D d$ na zona de iniciação $(5,62$ a $\left.12,40 \mathrm{~km} / \mathrm{km}^{2}\right)$, seguida pelos valores na zona de transporte $\left(2,57\right.$ a $\left.4,44 \mathrm{~km} / \mathrm{km}^{2}\right)$ e zona de deposição $(2,67$ a 4,36). Os valores mais altos na zona de iniciação indicam a necessidade de uma área bem drenada para a deflagração do processo. Em comparação, apesar de apresentar valores mais baixos em comparação aos exemplos anteriores $(1,57$ a 2,12), indicando drenagem pobre a moderada, as bacias avaliadas por Dotseva; Gerdjikov (2020) também tiveram ocorrência de corridas de detritos, o que pode indicar a influência de outros parâmetros morfométricos.

Semelhantemente ao $M$, o $\operatorname{Ir}$ avalia a rugosidade da bacia, ou seja, a produção e disponibilidade de sedimentos. De acordo com De Scally; Slaymaker; Owens (2001) altos valores de rugosidade indicam bacias mais propensas a processos intensos, como corridas de detritos. Jakob (1996) encontrou maiores valores de Ir para bacias limitadas pelo transporte em comparação às bacias limitadas pelo intemperismo (média de 5460 contra 3705, respectivamente). Os resultados mostraram que as bacias com ocorrência de corridas de detritos apresentaram valores mais altos (> 3500) em comparação às sem ocorrência (3698,01 e 5203,75 contra 3407,29 e 1563,15, respectivamente).

Com relação às correlações encontradas entre os parâmetros, a maior correlação encontrada foi positiva entre $A$ e $H d$ (0.966), indicando a tendência de aumento do valor de $H d$ em bacias com maior $A$. As bacias com menor área (Tingidor e Guarda-mão II) apresentaram o menor de valor de $H d$ (13 e 36, respectivamente), uma relação esperada, dado que áreas maiores tendem a ter uma rede de drenagem mais densa. A mesma relação foi observada entre os parâmetros $A 25$ e $A$ (0.888), $M$ e $R r(0.874)$, e $R r$ e $\Delta P l(0.807)$. Com uma tendência oposta à esperada, as bacias com maior $A$ (Gurutuba e Guarda-mão I) apresentaram maior $A 25$ (33,45 e $33,5 \%$, respectivamente). Geralmente, áreas menores, em especial bacias de zero ordem, 
tendem a possuir maior declividade em comparação às bacias maiores, sendo consideradas mais suscetíveis à ocorrência de corridas de detritos (SLAYMAKER, 1990; VANDINE, 1996). Acerca das correlações entre $M$ e $R r$ e $R r$ e $\Delta P l$, observa-se a relação entre os parâmetros que avaliam a rugosidade $(M$ e $R r)$, e a tendência de maior $\Delta P l$ juntamente à $R r$. No caso, as bacias com ocorrência de corridas (Tingidor e Guarda-mão I) se destacaram com valores mais altos para os parâmetros em questão.

Já entre as correlações negativas, destacam-se $M$ e $H d(-0.929), R r$ e $H d(-0.909), R r$ e $A(-0.904), D d$ e $C b(0.901), \Delta A$ e $D d(-0.820)$, e $A$ e $M(-0.809)$. Aqui, as bacias com e sem ocorrência se diferenciaram mais claramente. $\mathrm{O}$ maior valor de $M$ e menor valor de $H d$ foram observados na bacia Tingidor (0,58 e 13, respectivamente), enquanto o maior valor de $H d$ e menor de $M$ foram observados na bacia Gurutuba (63 e 0,33), semelhante à $R r$ e $H d(0,20$ e 63 na Gurutuba e 0,25 e 13 na Tingidor) e $\operatorname{Rr}$ e $A(0,20$ e 4,52 na Gurutuba e 0,25 e 2,02 na Tingidor). Da mesma forma, a bacia Guarda-mão II (sem ocorrência) apresentou maior valor de $D d$ dentre as bacias e menor $C b(6,81$ e 2,63), enquanto a bacia Tingidor (com ocorrência) apresentou o menor valor de $D d$ e maior $C b(4,45$ e 3,5$)$.

Mesma relação observada para $\Delta A$ e $D d$ (Guarda-mão II com 0,613 e 6,81, e Tingidor com 0,83 e 4,45). Por fim, com relação a $A$ e $M$, a bacia Gurutuba apresentou o maior valor de $A\left(4,52 \mathrm{~km}^{2}\right)$ e menor valor de $M(0,33)$, enquanto a Tingidor apresentou a relação inversa, menor valor de $A\left(2,02 \mathrm{~km}^{2}\right)$ e maior valor de $M$ entre as bacias $(0,58)$ relação observada anteriormente por Welsh; Davies (2011) para indicar áreas com maior ou menor predominância de corridas de detritos. 


\subsection{Conclusões}

- A partir da avaliação dos parâmetros morfométricos nas bacias afetadas por corrida de detritos em 2011 e 2014 e da comparação com as bacias sem ocorrência, foi possível verificar diferenças que podem ter contribuído não só para a deflagração dos processos, mas também para as particularidades de cada ocorrência. Os parâmetros isolados pouco expressam a influência na ocorrência ou não de corridas de detritos, sendo necessária a avaliação conjunta com outros parâmetros.

- Os parâmetros $\Delta P l, I r, R r, \Delta A$ e $M$ apresentaram valores mais críticos nas bacias Tingidor e Guarda-mão I. Nesse sentido, os resultados mostraram uma maior variação altimétrica e disponibilidade de sedimentos para transporte como um diferencial entre as bacias. Nestas bacias alguns parâmetros podem ter contribuído para as diferenças de magnitude.

- Na bacia Guarda-mão I, o volume inicial menor e o maior volume produzido pelo processo de arrastamento podem ter gerado valores mais críticos dos parâmetros $A, \Delta P l$, $H d, D d, A 25$ e $I r$. Os maiores valores de $\Delta P l$ e $A 25$ contribuíram para a iniciação do processo, $H d$ e $D d$ favoreceram o maior escoamento e intensidade dos processos e o valor mais crítico de $I r$ indicou a maior produção e disponibilidade de sedimentos.

- Na bacia Tingidor I, os parâmetros $R r, C b, \Delta A$ e $M$ se destacaram. A maior $\Delta A$ e $C b$ em uma $A$ menor pode ter contribuído para a intensidade e deflagração do processo por um volume maior de sedimentos. Da mesma forma, além de ser um indicador de produção de sedimentos na bacia, a $\operatorname{Rr}$ também demonstra a variação altimétrica da bacia, que a enquadra em um patamar crítico considerando tais fatores. $\mathrm{O}$ maior valor de $M$ indica o processo de corridas de detritos como o predominante na bacia, diferentemente da bacia Guarda-mão I. 
6. ÍNDICE MORFOMÉTRICO DE CLASSIFICAÇ̃̃O DE

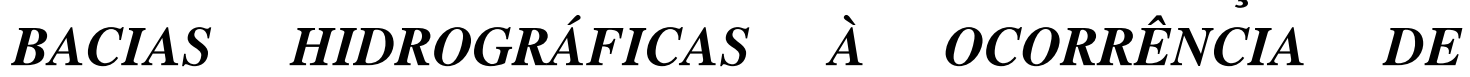
CORRIDAS DE DETRITOS: AVALIAÇÃO DE APLICABILIDADE EM AÇÕES DE PREVENÇ̃̃O E

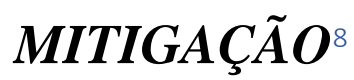

A utilização de métodos para classificação de áreas suscetíveis à processos hidrogeomorfológicos, como corridas de detritos e enxurradas de detritos, se tornou uma importante ferramenta de identificação e prevenção de áreas críticas. Sendo a bacia hidrográfica unidade de análise indicada pela Política Nacional de Proteção e Defesa Civil na forma da Lei No 12.608 de 10 de abril de 2012, a avaliação de suas características morfométricas e relação com a ocorrência de corridas de detritos tornou-se a abordagem predominante para estudo do processo e desenvolvimento de ações de prevenção, mitigação e resposta a futuras ocorrências. Dessa forma, este capítulo visa contribuir para com ações de mitigação e prevenção de ocorrências de corridas de detritos no Brasil, por meio de uma avaliação de métodos de classificação de áreas suscetíveis a partir da morfometria das bacias.

\subsection{Metodologia}

\subsection{1. Índice original proposto por Dias (2017)}

Foi utilizado aqui o índice de potencial de magnitude e suscetibilidade à ocorrência de corridas de detritos (Figura 6.1), inicialmente proposto por Dias (2017) com base na avaliação de áreas afetadas por corridas de detritos oriundas do evento de 1967 em Caraguatatuba (SP) ${ }^{9}$.

Para a sua elaboração quatro bacias afetadas por corridas de detritos com diferentes magnitudes foram avaliadas. A magnitude dos eventos em cada bacia foi estimada a partir da metodologia de classificação proposta por Jakob (2005b), considerando a área inundada pelo processo em $\mathrm{m}^{2}$ (Tabela 6.1).

Foram mapeados e hierarquizados os seguintes parâmetros morfométricos perfil longitudinal $(\Delta P l)$, hierarquia de drenagem $(H d)$, densidade de drenagem $(D d)$, área da bacia acima de $25^{\circ}(A 25)$, índice de rugosidade (Ir) e relação de relevo $(R r)$.

\footnotetext{
${ }^{8}$ Parte dos resultados contidos neste capítulo foram submetidos para avaliação no artigo "Parâmetros morfométricos e corridas de detritos: aplicação de índice de suscetibilidade em áreas afetadas na Serra do Mar paulista e paranaense".

${ }^{9}$ Capítulo 2.4.
} 
Figura 6.1: Índice de potencial de magnitude e suscetibilidade.

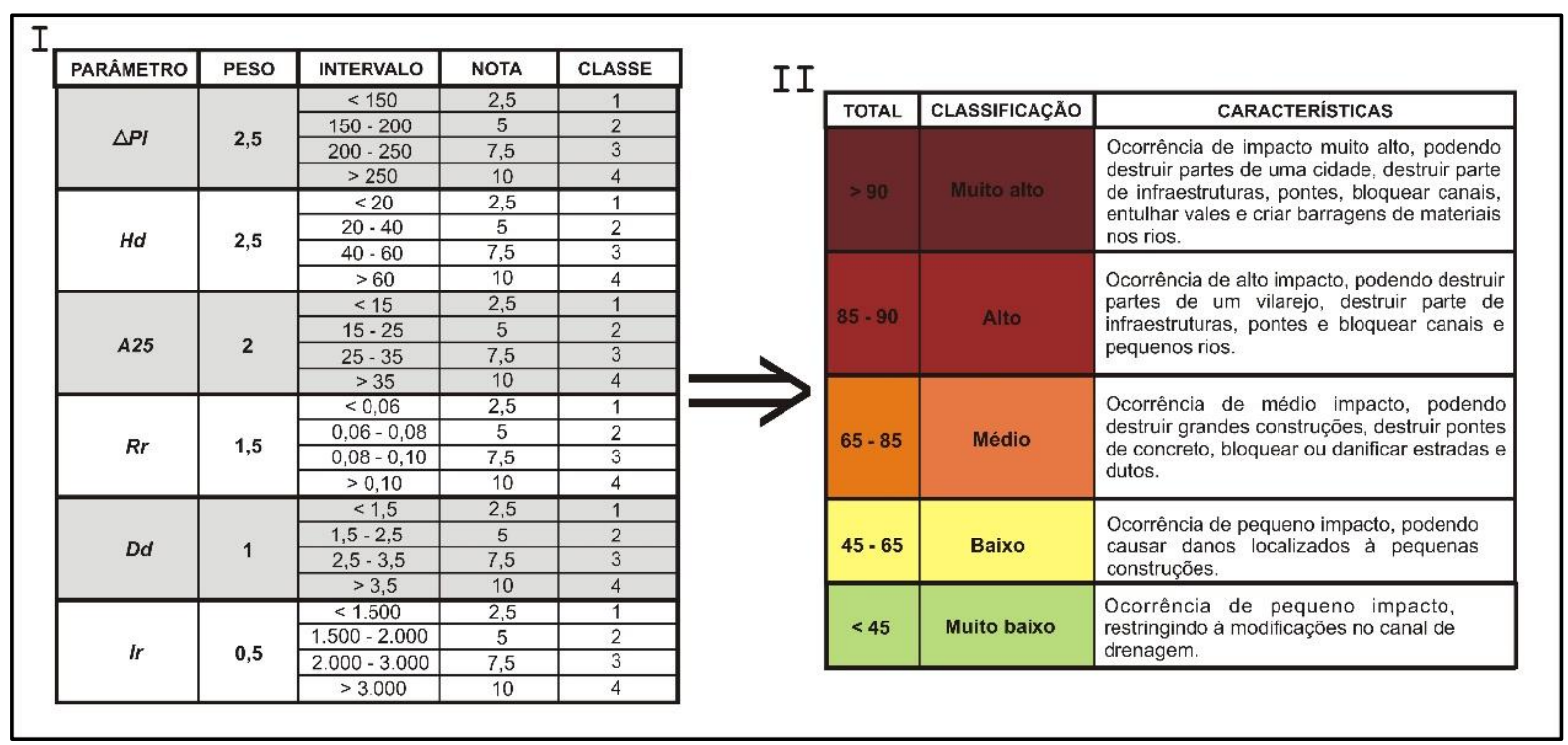

Fonte: Modificado de Dias (2017).

Tabela 6.1: Classificação de magnitude de corridas de detritos considerando apenas corridas de detritos com blocos.

\begin{tabular}{|c|l|l|l|l|}
\hline \multicolumn{5}{|c|}{ CLASSIFICAÇ̃̃̃O DE MAGNITUDE DE CORRIDAS DE DETRITOS } \\
\hline Nível & $\begin{array}{l}\text { Volume } \\
\left(\mathbf{m}^{3}\right)^{10}\end{array}$ & $\begin{array}{l}\text { Pico de Vazão } \\
\left(\mathbf{m}^{3} / \mathbf{s}\right)^{11}\end{array}$ & $\begin{array}{l}\text { Área } \\
\text { inundada } \\
\left(\mathbf{m}^{2}\right)^{12}\end{array}$ & Consequências Potenciais \\
\hline $\mathbf{1}$ & $<10^{2}$ & $<5$ & $<4 \times 10^{2}$ & Dano muito localizado em pequenas construções. \\
\hline $\mathbf{2}$ & $10^{2}-10^{3}$ & $5-30$ & $\begin{array}{l}4 \times 10^{2}-2 \times \\
10^{3}\end{array}$ & $\begin{array}{l}\text { Pode enterrar/arrastar carros, destruir pequenas } \\
\text { construções de madeira, derrubar árvores, bloquear } \\
\text { dutos descarrilar trens. }\end{array}$ \\
\hline $\mathbf{3}$ & $10^{3}-10^{4}$ & $30-200$ & $\begin{array}{l}2 \times 10^{3}-9 \times \\
10^{3}\end{array}$ & $\begin{array}{l}\text { Pode destruir grandes construções, destruir pontes de } \\
\text { concreto, bloquear ou danificar estradas e dutos. }\end{array}$ \\
\hline $\mathbf{4}$ & $10^{4}-10^{5}$ & $200-1.500$ & $\begin{array}{l}9 \times 10^{3}-4 \times \\
10^{4}\end{array}$ & $\begin{array}{l}\text { Pode destruir partes de um vilarejo, destruir parte de } \\
\text { infraestruturas, pontes e bloquear canais. }\end{array}$ \\
\hline $\mathbf{5}$ & $10^{5}-10^{6}$ & $1.500-12.000$ & $\begin{array}{l}4 \times 10^{4}-2 \times \\
10^{5}\end{array}$ & $\begin{array}{l}\text { Pode destruir partes de uma cidade, destruir florestas de } \\
\text { 2km² de área, bloquear canais e pequenos rios. }\end{array}$ \\
\hline $\mathbf{6}$ & $10^{6}-10^{7}$ & N/A & $>2 \times 10^{5}$ & $\begin{array}{l}\text { Pode partes de uma cidade, entulhar vales ou depósitos } \\
\text { de mais de 10 km² de tamanho, criar barragens de } \\
\text { materiais em rios (bloqueio). }\end{array}$ \\
\hline
\end{tabular}

Fonte: Modificado de Jakob (2005b).

\footnotetext{
${ }^{10}$ Utilizado para determinação da magnitude das corridas na bacia Tingidor e Guarda-mão I.

${ }^{11}$ Utilizado para determinação da magnitude das corridas na bacia Tingidor e Guarda-mão I.

${ }^{12}$ Utilizado para determinação da magnitude nas bacias afetadas em Caraguatatuba por Dias (2017).
} 


\subsection{2. Índice modificado (2021)}

Com base nos resultados da avaliação das bacias com e sem ocorrência recentes de corridas de detritos (Capítulo 5), o índice original foi modificado. Os parâmetros $\Delta P l, I r$ e $R r$ apresentaram uma diferença maior entre as bacias com e sem ocorrência. Dessa forma, foram modificados os intervalos e os pesos com base nos parâmetros que obtiveram valores mais críticos nas bacias com ocorrência em comparação com as sem ocorrência. Adicionalmente, os parâmetros $\triangle A, C b$ e $M$ foram incluídos no novo índice e ponderados de acordo com a sua influência na magnitude de cada bacia.

O parâmetro $A$ não foi tão determinante entre as bacias. Todas possuem tamanho inferior a $10 \mathrm{~km}^{2}$, conforme apontado por Slaymaker (1990). No entanto, observou-se uma forte correlação entre $A$ e o $H d$. Nesse sentido, optou-se por manter o parâmetro $H d$, assim como o parâmetro $D d$, apenas modificando os seus pesos com relação aos demais parâmetros. Consequentemente, o índice modificado contém agora 9 parâmetros $(\Delta P l, I r, \operatorname{Rr}, \Delta A, M, A 25$, $C b, D d$ e $H d)$.

Figura 6.2: Índice de potencial de magnitude e suscetibilidade modificado a partir dos resultados obtidos e discutidos no Capítulo 5.

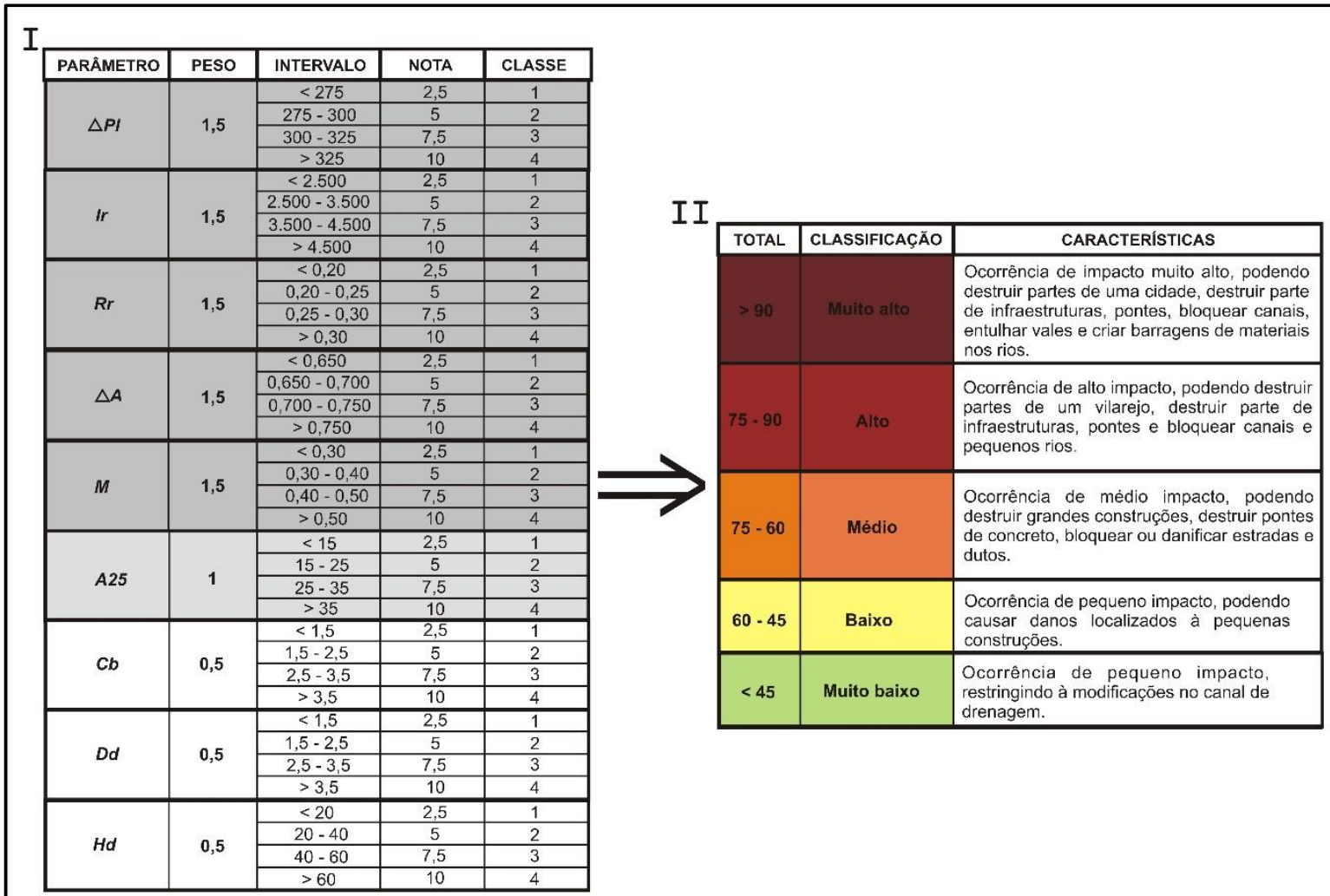




\subsection{Resultados}

\subsection{1. Índice original}

Os resultados para a aplicação do índice original proposto por Dias (2017) se mostraram inconsistentes com a avaliação das bacias com ocorrência e, principalmente na avaliação das bacias sem ocorrência de corridas de detritos (Tabela 6.2). A bacia Tingidor obteve o menor resultado de ponderação $(71,25)$, seguida pela Guarda-mão II (75). As bacias Guarda-mão I e Gurutuba obtiveram o mesmo valor $(88,75)$.

Tabela 6.2: Resultados da aplicação do Índice de potencial de magnitude e suscetibilidade proposto por Dias (2017).

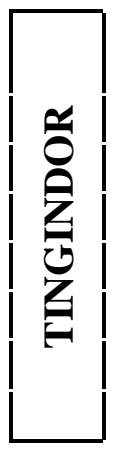

\begin{tabular}{|c|c|c|c|}
\hline PARÂMETRO & Unidade & Valor obtido & $\begin{array}{c}\text { VALOR } \\
\text { PONDERADO }\end{array}$ \\
\hline Perfil Longitudinal $(\Delta P l)$ & Gradiente Altimétrico (m) & 322 & 25 \\
\hline Hierarquia $(H d)$ & Adimensional & 13 & 6,25 \\
\hline Densidade de Drenagem $(D d)$ & $\mathrm{Km} / \mathrm{Km}^{2}$ & 4,45 & 10 \\
\hline Área $>25^{\circ}(A 25)$ & Porcentagem & 22,05 & 10 \\
\hline Índice de Rugosidade (Ir) & Adimensional & $3.698,01$ & 5 \\
\hline Relação de Relevo $(R r)$ & $\mathrm{m} / \mathrm{Km}$ & 0,25 & 15 \\
\hline \multicolumn{3}{|c|}{ RESULTADO DA PONDERAÇÃO: } & 71,25 \\
\hline
\end{tabular}

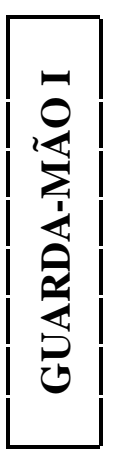

\begin{tabular}{|c|c|c|c|}
\hline PARÂMETRO & Unidade & Valor obtido & $\begin{array}{c}\text { VALOR } \\
\text { PONDERADO } \\
\end{array}$ \\
\hline Perfil Longitudinal $(\Delta P l)$ & Gradiente Altimétrico (m) & 352 & 25 \\
\hline Hierarquia $(H d)$ & Adimensional & 52 & 18,75 \\
\hline Densidade de Drenagem $(D d)$ & $\mathrm{Km} / \mathrm{Km}^{2}$ & 5,75 & 10 \\
\hline Área $>25^{\circ}(A 25)$ & Porcentagem & 33,5 & 15 \\
\hline Índice de Rugosidade (Ir) & Adimensional & $5.203,75$ & 5 \\
\hline Relação de Relevo $(R r)$ & $\mathrm{m} / \mathrm{Km}$ & 0,23 & 15 \\
\hline \multicolumn{3}{|c|}{ RESULTADO DA PONDERAÇÃO } & 88, \\
\hline
\end{tabular}

\begin{tabular}{|c|c|c|c|}
\hline PARÂMETRO & Unidade & Valor obtido & $\begin{array}{c}\text { VALOR } \\
\text { PONDERADO }\end{array}$ \\
\hline Perfil Longitudinal $(\Delta P l)$ & Gradiente Altimétrico (m) & 312 & 25 \\
\hline Hierarquia $(H d)$ & Adimensional & 36 & 12,5 \\
\hline Densidade de Drenagem $(D d)$ & $\mathrm{Km} / \mathrm{Km}^{2}$ & 6,81 & 10 \\
\hline Área $>25^{\circ}(A 25)$ & Porcentagem & 18,51 & 10 \\
\hline Índice de Rugosidade (Ir) & Adimensional & $1.563,15$ & 2,5 \\
\hline Relação de Relevo $(R r)$ & $\mathrm{m} / \mathrm{Km}$ & 0,23 & 15 \\
\hline \multicolumn{3}{|c|}{ RESULTADO DA PONDERAÇÃO: } & $7 !$ \\
\hline
\end{tabular}




\begin{tabular}{|c|c|c|c|c|}
\hline \multirow{8}{*}{ 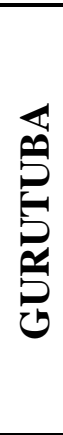 } & PARÂMETRO & Unidade & Valor obtido & $\begin{array}{c}\text { VALOR } \\
\text { PONDERADO }\end{array}$ \\
\hline & Perfil Longitudinal $(\Delta P l)$ & Gradiente Altimétrico (m) & 224 & 18,75 \\
\hline & Hierarquia $(H d)$ & Adimensional & 63 & 25 \\
\hline & Densidade de Drenagem $(D d)$ & $\mathrm{Km} / \mathrm{Km}^{2}$ & 4,86 & 10 \\
\hline & Área > $25^{\circ}(A 25)$ & Porcentagem & 33,45 & 15 \\
\hline & Índice de Rugosidade (Ir) & Adimensional & $3.407,29$ & 5 \\
\hline & Relação de Relevo $(R r)$ & $\mathrm{m} / \mathrm{Km}$ & 0,2 & 15 \\
\hline & \multicolumn{3}{|c|}{ RESULTADO DA PONDERAÇÃO: } & 88 \\
\hline
\end{tabular}

As bacias Tingidor e Guarda-mão I foram classificadas como nível médio e alto para a ocorrência de corridas de detritos, no entanto, a avaliação do evento indica que ambas as bacias tiveram corridas de detritos semelhantes considerando a magnitude, modificações na paisagem e danos. Nesse sentido, espera-se que ambas as bacias apresentem classificação semelhante. Da mesma forma, as bacias Gurutuba e Guarda-mão II apresentaram classificação maior do que a esperada, mas não houve registro de ocorrência de corridas de detritos na ocasião do evento de 2014 apesar do grande número de escorregamentos.

Observa-se que o intervalo de classificação dos parâmetros, em especial para $\Delta P l$, deixou as bacias com o mesmo valor ponderado, no caso, o valor máximo possível (25). Conforme verificado no Capítulo 5, as bacias com ocorrência apresentaram um valor maior para $\Delta P l$ em comparação às bacias sem ocorrência. $O$ que pode ter contribuído para a deflagração do processo.

O parâmetro $H d$ não se mostrou significativo entre as bacias com e sem ocorrência, no entanto, o parâmetro possui o mesmo peso que $\Delta P l$. Foi observada a relação positiva entre a $A$ e $H d$ nas bacias. Nesse sentido, a bacia Gurutuba, que apresentou maior $A\left(4,52 \mathrm{~km}^{2}\right)$ foi favorecida, apresentando também maior $H d(63)$ e, portanto, maior valor ponderado (25). Da mesma forma, o peso maior atribuído à $H d$ pode ter contribuído para a classificação menor da bacia Tingidor em relação à bacia Guarda-mão I, uma vez que ela apresentou o menor valor de $H d$ dentre as bacias avaliadas.

A $D d$ não mostrou um diferencial entre as bacias com e sem ocorrência, uma vez que todas apresentaram valores que podem ser considerados típicos de bacias bem drenadas. Por conseguinte, todas as bacias apresentaram o valor ponderado máximo para $D d$. Com a mesma dinâmica, em relação ao parâmetro A25 apresentou a mesma dinâmica, uma vez que todas as bacias estão localizadas em áreas escarpadas. Aqui, mais uma vez, a bacia Gurutuba (sem ocorrência) foi favorecida em relação à bacia Tingidor (com ocorrência), ficando com o mesmo valor ponderado da bacia Guarda-mão I (15). 
Nos resultados no Capítulo 5 verificou-se que os parâmetros $I r$ e $R r$ apresentaram diferenças significativas entre as bacias com e sem ocorrência, o que não se refletiu na classificação das bacias a partir do índice original. Conforme exposto, as bacias com ocorrência apresentaram valor acima de 3.500 para $I r$, enquanto as bacias sem ocorrência apresentaram valores abaixo de limiar. Nesse sentido, observa-se que apenas a bacia Guarda-mão II obteve valor ponderado abaixo do valor máximo $(2,5)$, enquanto as demais bacias obtiveram valor ponderado máximo para a classificação de acordo com $\operatorname{Ir}(5)$.

Referente ao parâmetro $R r$, todas as bacias foram classificadas com o maior valor ponderado (15), apesar de variar nas bacias com e sem ocorrência. Tal discrepância pode estar relacionada ao intervalo de classificação proposto pelo índice, que considera valores de $I r$ bem abaixo dos observados nas bacias avaliadas.

É importante salientar também que os parâmetros $\Delta A, M$ e $C b$, que se mostraram significativos entre as bacias com e sem ocorrência, não fazem parte do índice proposto por Dias (2017).

\subsection{2. Índice modificado}

O índice modificado contou com a inclusão dos parâmetros $\triangle A, M$ e $C b$ e reclassificação do peso e intervalo dos parâmetros $\Delta P l, I r$ e $R r$ (Tabela 6.3), com base nos resultados obtidos no Capítulo 5.

Na nova classificação, as bacias Guarda-mão e Tingidor obtiveram o maior valor $(81,25$ e 76,25), seguidas pela Gurutuba $(58,75)$ e Guarda-mão II com o menor valor $(48,75)$.

Tabela 6.3: Resultados da aplicação do Índice de potencial de magnitude e suscetibilidade modificado a partir dos resultados obtidos e discutidos no Capítulo 5.

\begin{tabular}{|c|c|c|c|c|}
\hline \multirow{11}{*}{ 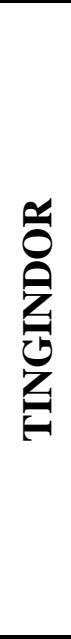 } & PARÂMETRO & Unidade & Valor obtido & $\begin{array}{c}\text { VALOR } \\
\text { PONDERADO }\end{array}$ \\
\hline & Perfil Longitudinal $(\Delta P l)$ & Gradiente Altimétrico (m) & 322 & 11,25 \\
\hline & Índice de Rugosidade (Ir) & Adimensional & $3.698,01$ & 11,25 \\
\hline & Relação de Relevo $(R r)$ & $\mathrm{m} / \mathrm{m}$ & 0,25 & 7,5 \\
\hline & Amplitude altimétrica $(\Delta A)$ & $\mathrm{Km}$ & 0,83 & 15 \\
\hline & Índice de Melton $(M)$ & Adimensional & 0,58 & 15 \\
\hline & Área > $25^{\circ}(A 25)$ & Porcentagem & 22,05 & 5 \\
\hline & Comprimento da bacia $(\mathrm{Cb})$ & $\mathrm{Km}$ & 3,50 & 5 \\
\hline & Densidade de Drenagem $(D d)$ & $\mathrm{Km} / \mathrm{Km}^{2}$ & 4,45 & 5 \\
\hline & Hierarquia $(H d)$ & Adimensional & 13 & 1,25 \\
\hline & \multicolumn{3}{|c|}{ RESULTADO DA PONDERAÇÃO: } & 76,25 \\
\hline
\end{tabular}




\begin{tabular}{|c|c|c|}
\hline Unidade & Valor obtido & $\begin{array}{c}\text { VALOR } \\
\text { PONDERADO }\end{array}$ \\
\hline Gradiente Altimétrico (m) & 352 & 15 \\
\hline Adimensional & 5203,75 & 15 \\
\hline $\mathrm{m} / \mathrm{m}$ & 0,23 & 7,5 \\
\hline $\mathrm{Km}$ & 0,753 & 15 \\
\hline Adimensional & 0,38 & 7,5 \\
\hline Porcentagem & 33,50 & 7,5 \\
\hline $\mathrm{Km}$ & 3,30 & 3,75 \\
\hline $\mathrm{Km} / \mathrm{Km}^{2}$ & 5,75 & 5 \\
\hline Adimensional & 52 & 5 \\
\hline \multicolumn{2}{|c|}{ RESULTADO DA PONDERAÇÃO: } & 81,2 \\
\hline
\end{tabular}

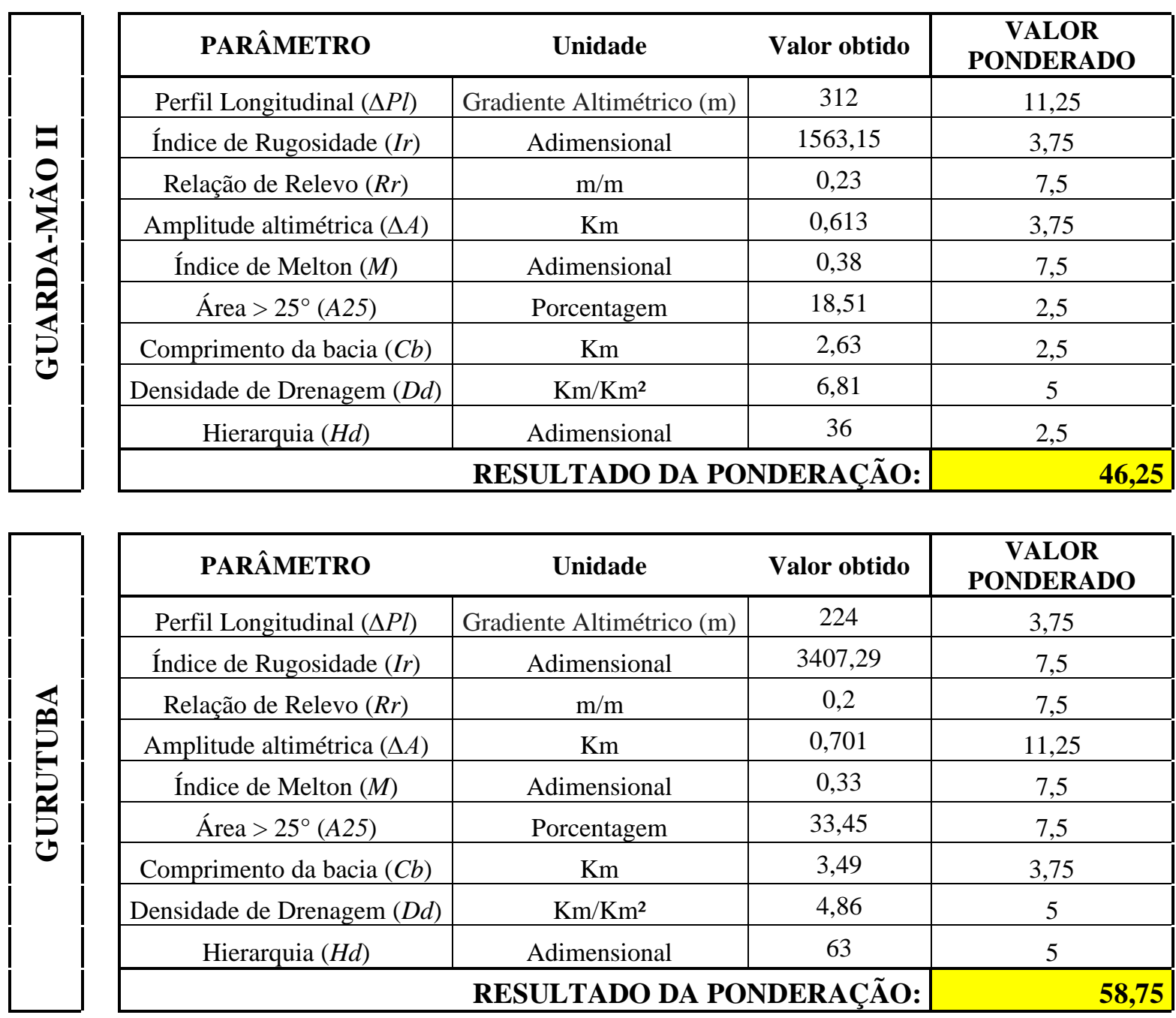

As bacias Tingidor e Guarda-mão I foram classificadas como nível alto para ocorrência de corridas de detritos, enquanto as bacias Guarda-mão II e Gurutuba foram classificadas como nível baixo. Considerando os resultados obtidos a respeito das ocorrências de corridas de detritos, a classificação das bacias em nível alto mostra-se adequada, sobretudo com relação à 
diferença no resultado da ponderação final nas bacias Tingidor e Guarda-mão I, que reflete algumas diferenças a respeito das características morfométricas das bacias e do processo de corrida de detritos. Da mesma forma, considerando as bacias sem ocorrência, o resultado da ponderação final também se mostra adequado, com a bacia Gurutuba apresentando maior valor dado à valores mais críticos em determinados parâmetros (ex. Ir e A25) em comparação à bacia Guarda-mão II, que obteve o valor ponderado mais baixo.

A modificação no intervalo de classificação e valor de ponderação dos parâmetros $\Delta P l$, $I r, \operatorname{Rr}, \Delta A$ e $M$, resultou em uma classificação mais representativa das características das bacias avaliadas, considerando o processo de corridas de detritos. Para a $\Delta P l$, na nova classificação das bacias, apenas a Guarda-mão I obteve valor máximo de ponderação para o parâmetro (15), seguida pelas bacias Tingidor e Guarda-mão II (ambas com 11,25) e a bacia Gurutuba, com o menor valor $(3,75)$.

Para o parâmetro $I r$, apenas a bacia Guarda-mão I obteve o maior valor de ponderação (15), seguida pela bacia Tingidor, que obteve o segundo maior valor (11,25). As bacias Gurutuba e Guarda-mão II obtiveram os menores valores 7,5 e 3,75, respectivamente). Já para $R r$, apesar da mudança no intervalo de classificação e alteração no peso, todas as bacias obtiveram o mesmo valor de ponderação $(7,5)$.

Os parâmetros $\Delta A$ e $M$, incluídos no novo índice, se mostraram representativos entre as bacias com e sem ocorrência. As bacias Tingidor e Guarda-mão I foram classificadas com o maior valor de ponderação para $\Delta A(15)$, enquanto as bacias Guarda-mão II e Gurutuba ficaram com valor ponderado mais baixo (3,75 e 11,25, respectivamente). Já para o $M$, a bacia Tingidor obteve o maior valor entre as bacias (15), enquanto as demais ficaram com valor ponderado inferior $(7,5)$.

O A25 teve sua importância reduzida na nova classificação, uma vez que não se mostrou um diferencial entre as bacias com e sem ocorrência. As bacias Guarda-mão I e Gurutuba obtiveram o maior valor de ponderação $(7,5)$, seguidas pela bacia Tingidor (5) e a bacia Guardamão II $(2,5)$. Da mesma forma, os parâmetros $D d$ e $H d$ passaram a ter peso menor na nova classificação, culminando com os valores mais equilibrados entre as bacias. Para $D d$ todas as bacias obtiveram o valor de ponderação máximo (5); já para $H d$ as bacias Guarda-mão I e Gurutuba ficaram com o maior valor de ponderação (5), seguidas pelas bacias Guarda-mão II $(2,5)$ e Tingidor, que obteve o menor valor $(1,25)$.

Por fim, foi incluído no novo índice o parâmetro $C b$, com peso igual aos parâmetros $D d$ e $H d(0,5)$ e intervalo de classificação variando de $<1,5(\mathrm{~km})$ a $<3,5(\mathrm{~km})$. Aqui, a bacia 
Tingidor obteve o maior valor ponderado (5), seguida pelas bacias Guarda-mão I e Gurutuba, ambas com valor ponderado de 3,75. A bacia Guarda-mão II obteve o menor valor $(2,5)$. 


\subsection{Discussões}

A aplicação dos dois índices nas áreas de estudo demonstra as diferenças referentes à sua elaboração prévia. O índice denominado "original" foi elaborado a partir da avaliação de bacias com ocorrência de corridas de detritos em Caraguatatuba, oriundas do evento de 1967 (DIAS, 2017). Por se tratar de um evento com mais de 50 anos, as evidências na paisagem não estavam mais tão aparentes. Nesse sentido, a avaliação das ocorrências como feita no Capítulo 4, estimando velocidade e vazão de pico das corridas já não era possível de forma tão acurada. Como forma de determinar a magnitude das corridas, Dias (2017) também utilizou a metodologia proposta por Jakob (2005b), no entanto, utilizando a área inundada $\left(\mathrm{m}^{2}\right)$ como critério para determinar a magnitude, variando entre 1 e 3 (Figura 6.3).

Figura 6.3: Classificação da magnitude das corridas de detritos em Caraguatatuba a partir da metodologia de Jakob (2005b).

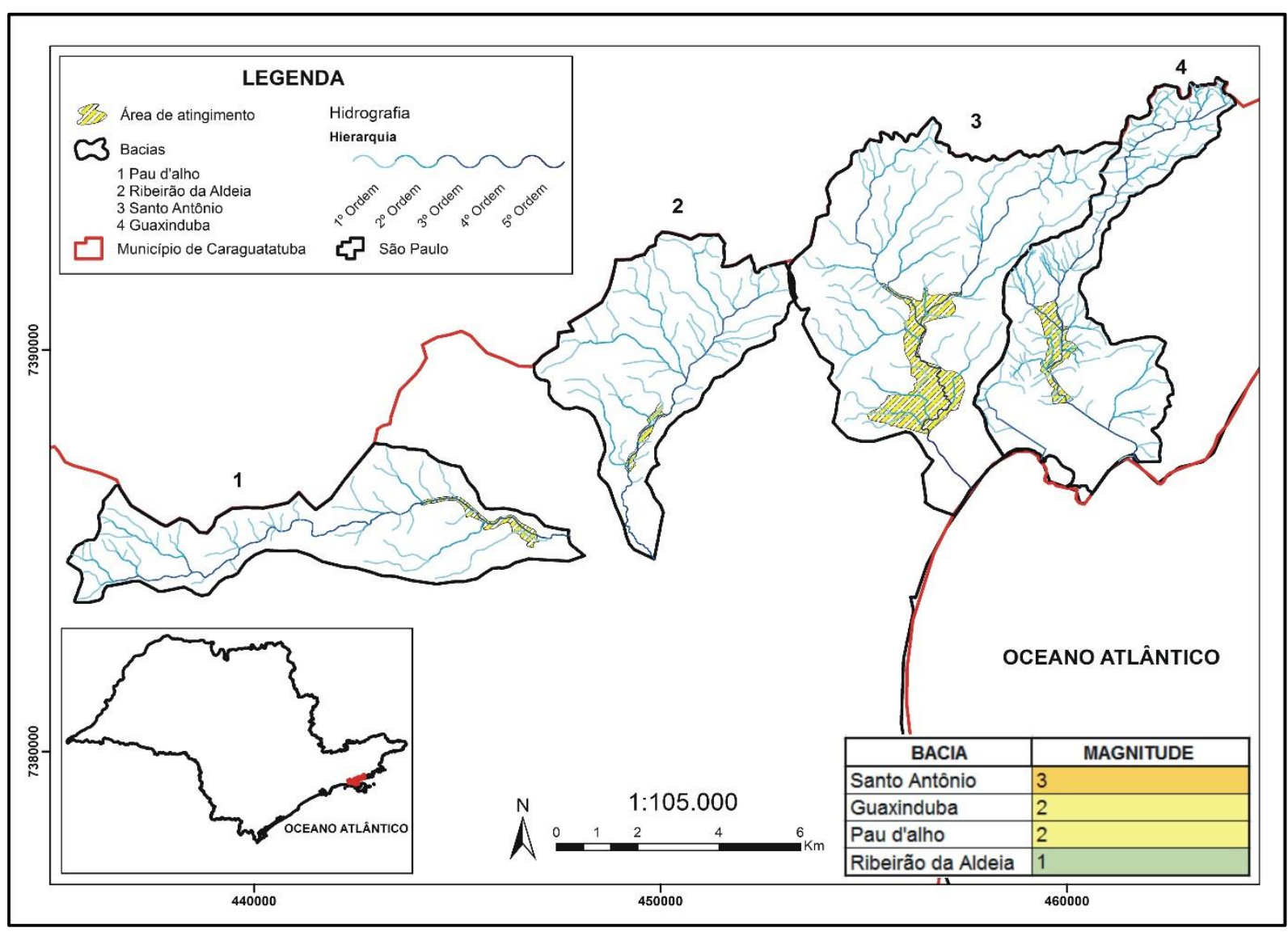

Fonte: modificado de Dias (2017).

Em adição, apenas bacias afetadas por corridas de detritos em 1967 foram avaliadas para a criação do índice original em Caraguatatuba, o que pode ter contribuído para uma padronização dos intervalos dos parâmetros selecionados, não demonstrando com clareza as 
influências de cada parâmetro no processo decorrido, algo visto na avaliação da morfometria das bacias no Capítulo 5. Conforme verificado, as bacias sem ocorrência obtiveram uma classificação incompatível, sobretudo considerando as bacias Tingidor e Gurutuba. Outro ponto importante é a influência de outras características morfométricas na diferenciação das bacias com e sem ocorrências, com destaque para os parâmetros $\Delta A$ e $M$.

As mudanças efetuadas tanto no intervalo de classificação quanto no peso dos parâmetros proporcionaram um equilíbrio, com uma classificação mais condizente com a morfometria das bacias avaliadas e a ocorrência de corridas de detritos. Os parâmetros $\Delta P l, I r$, $\operatorname{Rr}, \Delta A$ e $M$ se mostraram cruciais na diferenciação entre as bacias com e sem ocorrência. Dessa forma, o mesmo peso foi atribuído para eles $(1,5)$.

A aplicação dos parâmetros $\Delta P l$ e $\Delta A$ se mostrou mais significativa para identificar a diferenciação de aspectos morfométricos das bacias com e sem ocorrência. Bacias com ocorrência possuem um maior valor para $\Delta P l$ e $\Delta A$ em comparação às bacias sem ocorrência. Tal como pontuado por diversos autores, as corridas de detritos são um processo induzido, sobretudo pela gravidade, necessitando de características topográficas específicas para a sua deflagração, sendo a principal delas elevado gradiente altimétrico (COSTA, 1984; TAKAHASHI, 2007). Nesse sentido, para $\Delta P l$ observou-se a necessidade de estabelecimento de um intervalo de classificação com limiar mais crítico, no caso, com valor máximo > 325 metros, 75 metros a mais do que o índice original. Da mesma forma, a inclusão da $\Delta A$ se mostrou crucial na classificação das bacias, com intervalo de classificação variando entre < 0,650 e $>0,750 \mathrm{~km}$.

Da mesma forma, apesar de constarem no índice original, os parâmetros $I r$ e $R r$ possuíam intervalo de classificação e peso diferentes. A disponibilidade de sedimentos para transporte é um importante fator necessário para a deflagração de corridas de detritos, e, sobretudo, a sua magnitude final a partir do volume total mobilizado. Tal característica pode ser averiguada a partir dos parâmetros $\operatorname{Ir}$ e $R r$, sendo o segundo o mais comumente utilizado (CENDERELLI; STEVEN KITE, 1998; JAKOB, 1996; PORTILLA; CHEVALIER; HÜRLIMANN, 2010; WILFORD et al., 2004).

No índice original, os parâmetros possuíam peso e intervalo de classificação menor, influenciando negativamente na classificação das bacias com ocorrência. Conforme observado no Capítulo 5, a diferença de valores para $I r$ e $R r$ foi crucial na diferenciação entre as bacias, com as bacias com ocorrência apresentando valores mais críticos, sobretudo, o Ir. A partir da nova classificação no índice modificado, observa-se um maior equilíbrio entre as bacias, onde os valores críticos para Ir nas bacias Tingidor e Guarda-mão I podem ser destacados na 
classificação, com ambas apresentando os maiores valores de ponderação em comparação às bacias sem ocorrência.

Apesar de demonstrar diferenças entre as bacias, os valores para $R r$ não foram tão distintos quanto $I r$. Por se tratar de um parâmetro que avalia a rugosidade da bacia a partir de uma relação entre comprimento da bacia e sua amplitude altimétrica, a similaridade entre as áreas pode ter contribuído para os valores próximos.

Comparando os valores com a literatura, verifica-se que estes podem ser considerados medianos, uma vez que valores mais críticos poderiam ser observados. Nesse sentido, e considerando que valores mais críticos tendem a ser observados em áreas montanhosas no hemisfério norte, como na Columbia Britânica, com 0,75 (JAKOB, 1996) e Romênia, com 0,56 (ILINCA, 2021), e o número limitado de dados referentes ao hemisfério sul, o intervalo de classificação foi modificado de forma a representar as variações observadas nas áreas estudadas, com intervalo entre < 0,20 (mínimo) a > 0,30 (máximo).

De forma semelhante, o parâmetro $M$ avalia a rugosidade, utilizando a amplitude altimétrica e área da bacia. Diversos autores vem utilizando este parâmetro para determinar o processo hidrogeomorfológico predominante na bacia, com valores variando de $<0,30$ a $>0,60$ (ILINCA, 2021; WELSH; DAVIES, 2011). O M não estava no índice original, no entanto, a avaliação das bacias apontou para a sua influência frente a outros parâmetros, sobretudo na bacia Tingidor, que apresentou o maior valor $(0,58)$ dentre todas, indicando a predominância do processo de corridas de detritos. Os valores em torno de 0,30 são apontados pelos autores como indicadores da predominância de outros processos hidrogeomorfológicos, tais como a enxurrada de detritos, que após a deposição dos materiais na Guarda-mão I, predominou na bacia. Nesse sentido, na classificação das bacias no índice modificado, a Tingidor obteve o maior valor ponderado para o parâmetro (15), enquanto as demais bacias obtiveram o valor ponderado de 7,5, equilibrando, assim, as características morfométricas de cada bacia.

O A25 teve o seu peso modificado no novo índice, passando de peso 2 para peso1, assim como os parâmetros $D d$ e $H d$ (mudança de peso 1 e 2,5, respectivamente, para peso 0,5). Uma vez que todas as bacias se encontram em área serrana, é esperado um predomínio de ângulo acima de $25^{\circ}$. Da mesma forma, dada à característica do processo no Brasil (deflagrados a partir de aporte de matérias nas drenagens em bacias bem drenadas), diminui-se a importância dada a estes parâmetros em benefício de outros parâmetros que se mostraram mais relevantes na diferenciação entre as bacias com e sem ocorrência (ex. $\Delta P l$ e $I r$ ), o que também se aplica ao parâmetro $C b$. 


\subsection{Conclusões}

- A aplicação do índice original se mostrou menos eficiente para diferenciar as bacias com e sem ocorrência, não refletindo diretamente as características morfométricas. A modificação do índice, sobretudo com relação aos parâmetros que demonstraram maior destaque nas bacias com ocorrência, proporcionou uma classificação mais condizente com os processos ocorridos recentemente.

- Considerando o índice modificado, as bacias do Guarda-mão I e Gurutuba foram classificadas com suscetibilidade média, com impacto baixo e danos localizados à pequenas construções. Já as bacias Tingidor e Guarda-mão I foram classificadas como suscetibilidade alta, indicando um potencial alto de impacto às infraestruturas, podendo destruir partes de um vilarejo ou bloquear canais. Tais aspectos foram observados de fato nas ocorrências nas duas bacias. Na bacia Tingidor houve obstrução de canais pelos materiais transportados e destruição de moradias em alvenaria nas margens do rio. Na bacia Guarda-mão I o elevado volume de materiais transportados provocou o entulhamento do vale e soterramento e destruição de moradias em alvenaria, como agravante da enxurrada de detritos que seguiu após a deposição inicial, causando danos ao centro urbano do município.

- Para todas as bacias com média, mas sobretudo alta suscetibilidade, fica evidente a importância de um monitoramento constante a fim de evitar a reocupação da área e consequentemente reduzir ou mesmo evitar novas ocorrências catastróficas.

- Ressalta-se que o índice modificado foi aplicado e calibrado para bacias na Serra do Mar com áreas $<10 \mathrm{~km}^{2}$, tamanho indicado na literatura como mais propenso para ocorrência de corridas de detritos. Dessa forma, para aplicação em outras bacias, recomenda-se que este limiar seja respeitado. 


\section{CONSIDERAÇÕES FINAIS E RECOMENDAÇÕES}

Este capítulo tem o objetivo de resumir o trabalho e destacar as principais contribuições, relacionando-as com os objetivos e hipótese da pesquisa. Conclusões mais detalhadas de cada etapa da pesquisa estão disponíveis nos subcapítulos 4.4, 5.5 e 6.4. São discutidas também implicações para a avaliação de suscetibilidade e ideias e recomendações para trabalhos futuros a respeito do estudo de corridas de detritos no Brasil.

\subsection{Resumo das principais contribuições da tese}

Esta pesquisa contribui para a compreensão da dinâmica das corridas de detritos no Brasil, sobretudo, na avaliação detalhada de ocorrências pretéritas e sua relação com as características morfométricas das bacias.

A avaliação das ocorrências recentes de corridas de detritos em diferentes localidades da Serra do Mar (Serra da Prata/PR e Itaoca/SP) mostrou a grande relevância do processo de arrastamento no volume total produzido pelo processo e as implicações das características morfológicas e morfométricas de cada bacia para a deflagração e dinâmica do processo. Conforme observado por diversos autores na literatura, o arrastamento é o principal processo relacionado à produção de sedimentos pelas corridas de detritos, podendo aumentar o $V_{i}$ milhares de $\mathrm{m}^{3}$ no $V_{t}$. Neste sentido, um elevado $V_{i}$ seria tão determinante para a magnitude do processo quanto o volume de sedimentos mobilizados por meio do arrastamento.

As características morfométricas das áreas afetadas ressaltaram as possíveis diferenças para as dinâmicas nestas bacias. Por estarem localizadas em áreas suscetíveis à processos de movimentos de massa, as bacias estudadas apresentaram valores próximos com relação à alguns parâmetros, com destaque para o $A 25$ e a $R r$. No entanto, foi possível identificar valores críticos que, combinados, podem ter contribuído para as dinâmicas distintas entre as bacias, sobretudo no que se refere à deflagração do processo. Tal diferença foi fundamental para melhor compreender a influência das características morfométricas e sua relação com a ocorrência de corridas de detritos, em especial, pensando na classificação das áreas com base na sua morfometria.

A aplicação do índice original não se mostrou condizente com o cenário observado nas bacias, classificando uma área não afetada pelo evento recente como "alta suscetibilidade" e uma área afetada como "média suscetibilidade", apesar das áreas afetadas terem apresentado a mesma magnitude. Dessa forma, foi necessária a calibração e a inclusão de outros parâmetros. A partir da revisão dos intervalos e dos pesos, e inclusão dos novos parâmetros, foi elaborada 
uma versão revisada, na qual as bacias apresentam classificação mais próxima com as ocorrências de corridas de detritos nas mesmas.

Conforme o exposto, o objetivo principal da pesquisa, assim como os objetivos específicos foram cumpridos, com a avaliação do índice original, a sua não validação perante as características observadas, e subsequente revisão e reaplicação, obtendo, então, resultados condizentes com as características das bacias e com os processos de corridas de detritos observados. Os objetivos específicos propostos foram essenciais para alcançar o objetivo principal da pesquisa, sendo cumpridos integralmente.

A hipótese da pesquisa foi parcialmente confirmada, uma vez que o índice original não apresentou uma classificação adequada das áreas estudadas. No entanto, a partir da caracterização detalhada das ocorrências e a avaliação das características morfométricas foi possível verificar diferenças nos valores e limiares que proporcionaram a sua revisão e calibração, culminando em uma versão modificada do índice, que poderá ser utilizada em outras áreas.

\subsection{Implicações para avaliação da suscetibilidade e desafios da pesquisa}

A avaliação da suscetibilidade a movimentos de massa, em especial, corridas de detritos, deve ser um processo constante, assim como o monitoramento de áreas já afetadas. Esta pesquisa fornece informações detalhadas a respeito de duas ocorrências recentes de corridas de detritos no país, assim como de suas principais características morfométricas. Os métodos utilizados aqui podem ser reaplicados para outras áreas.

O registro e a caracterização de ocorrências de corridas de detritos são parte fundamental na avaliação não apenas da suscetibilidade, mas também na avaliação das características específicas do processo de corridas de detritos no Brasil, contribuindo não somente para o entendimento mais amplo do processo, mas também para sua comparação com outras ocorrências no mundo.

As características dos depósitos de corridas de detritos observadas em campo foram bastante semelhantes nas duas áreas. Ressalta-se que o uso de uma ficha em campo para a identificação das feições se mostrou eficiente e passível de utilização em outras áreas, podendo, assim, contribuir para o trabalho de mapeamento e determinação de suscetibilidade.

Um dos maiores desafios desta pesquisa foi a aquisição de dados base para o mapeamento das características do relevo, necessários para o mapeamento dos parâmetros morfométricos. Apesar de contar com mapeamentos topográficos nacionais, a escala foi um 
empecilho na sua utilização se tratando de áreas localizadas em diferentes estados, levando a utilização de uma base comum a todas as áreas.

Da mesma forma, a caracterização em campo ou via sensores remotos de processos ocorridos a mais de 5 anos ( 8 anos na ocasião do mapeamento na Serra da Prata) também se mostrou um desafio dada à rápida regeneração da vegetação, ocultando as evidências destes processos na paisagem, e a ausência de imagens de satélite e fotografias aéreas com curto intervalo de tempo, capazes de verificar recorrências em uma mesma área. Nesse sentido, acredita-se que o advento de novas tecnologias no século XXI, com destaque à disponibilidade de imagens de satélite e o Google Earth tendem a facilitar o trabalho nos próximos anos, sobretudo considerando futuras ocorrências.

\subsection{Recomendações para trabalhos futuros}

Oportunidade para melhorar e expandir este trabalho são apresentadas a seguir:

\section{a) Incorporação métodos de datação e investigação de ocorrências pretéritas}

Devido à regeneração rápida da vegetação e à indisponibilidade de imagens de satélite ou fotografias aéreas com curto intervalo de tempo, logo após o evento, muitas áreas já afetadas por corridas de detritos não apresentam evidências físicas passíveis de serem visualizadas e mapeadas em campo. Nesse sentido, tornam-se necessárias técnicas de datação que possam indicar a recorrência dos processos, tais como dendrocronologia e uso do GPR para identificação de depósitos pretéritos.

b) Monitoramento constante de áreas afetadas e geração de banco de dados nacional Grande parte das ocorrências de movimentos de massa no país é registrada apenas em caso de danos sociais ou econômicos. O monitoramento de áreas já identificadas como de alta suscetibilidade (devido à suas características geológicas-geomorfológicas), como, por exemplo, a Serra do Mar, deve ser feito, sobretudo após a ocorrência de eventos pluviométricos extremos, contribuindo, assim, para a geração de um banco de dados a respeito não só das ocorrências, mas também de limiares críticos de chuva, que, como observado nesta tese, pode variar de uma área para outra. A caracterização detalhada de ocorrências de corridas de detritos deve se tornar uma prática mais frequente em ambientes montanhosos e submetidos a grandes volumes pluviométricos. Informações sobre velocidade e pico de vazão, por exemplo, são mais bem calculadas a partir de evidências observadas em campo. Da mesma forma, as características dos depósitos estão mais evidentes na paisagem, sem ainda a influência da vegetação, 
podendo oferecer um panorama único do processo, que não poderia ser observado ao realizar o mesmo trabalho de mapeamento anos mais tarde, dada a regeneração intensa da vegetação em meio tropical-úmido.

\section{c) Ampliação da avaliação estatística}

Dada a proposta inicial da tese de se analisar em detalhe bacias afetadas por corridas de detritos, poucas áreas foram avaliadas, considerando uma análise estatística mais robusta. Nesse sentido, recomenda-se a avaliação das características morfométricas em mais áreas suscetíveis e afetadas por corridas de detritos, a fim de obter um maior banco de dados a respeito das características morfométricas das bacias no Brasil.

d) Aplicação do índice em mais áreas e calibração e aplicação de modelos matemáticos

O índice de suscetibilidade foi calibrado de acordo com os resultados obtidos nesta pesquisa. Dessa forma, torna-se necessária a aplicação do mesmo em outras áreas com ocorrência e suscetíveis ao processo de corridas de detritos para uma maior avaliação de sua aplicabilidade em ações preventivas. A caracterização das ocorrências de corridas de detritos nas áreas aqui estudadas disponibiliza dados necessários para a aplicação de modelos matemáticos tais como DAM3D e RAMMS. Tais modelos podem fornecer informações fundamentais sobre os processos ocorridos e suas características específicas, como, por exemplo, a respeito de mecanismos inerentes ao fluxo, proporcionando uma maior compreensão sobre o processo de corridas de detritos. 


\section{REFERÊNCIAS}

AB'SABER, Aziz Nacib. Contribuição à geomorfologia do litoral Paulista. Revista Brasileira de Geografia, [S. l.], v. 1, p. 3-48, 1955.

AB'SABER, Aziz Nacib. A Terra Paulista. Boletim Paulista de Geografia, [S. l.], v. 23, p. 3$85,1956$.

ABELE, G. Rockslide movement supported by the mobilization of groundwater-saturated valley floor sediments. ZEITSCHRIFT FUR GEOMORPHOLOGIE, [S. l.], v. 41, p. 1-20, 1997.

ÁGUAS PARANÁ, Instituto das Águas do Paraná. Sistema de Informação Hidrológica. 2018. Disponível em: http://www.sih-web.aguasparana.pr.gov.br/sihweb/gerarRelatorioTotaisMensaisPrecipitacao.do?action=carregarInterfaceInicial.

ALASKA SATELLITE FACILITY, ASF. Vertex is the Alaska Satellite Facility's data portal for remotely sensed imagery of the Earth. 2019.

ALMEIDA, Fernando Flávio Marques De. Fundamentos geológicos do relevo paulista. Geologia do Estado de São Paulo, [S. l.], v. 41, p. 179, 1964.

ALMEIDA, Fernando Flávio Marques De; CARNEIRO, Celso Dalré. Origem e Evolução da Serra do Mar. Revista Brasileira de Geociências, [S. l.], v. 28, p. 1335-150, 1998.

ALTRICHTER, G.; GRAMANI, Marcelo Fischer. No Deslizamentos e Corridas de Lama no Km 52 da Rodovia dos Imigrantes. In: XVII CONGRESSO BRASILEIRO DE MECÂNICA DOS SOLOS E ENGENHARIA GEOTÉCNICA / VII CONGRESSO LUSO-BRASILEIRO DE GEOTECNIA / VI SIMPÓSIO BRASILEIRO DE MECÂNICA DAS ROCHAS / VI SIMPÓSIO BRASILEIRO DE JOVENS GEOTÉCNICOS. GOIÂNIA, BRASIL 2014, Anais [...]. [s.l: s.n.] p. 8.

ARANGO, María Isabel; ARISTIZÁBAL, Edier; GÓMEZ, Federico. Morphometrical analysis of torrential flows-prone catchments in tropical and mountainous terrain of the Colombian Andes by machine learning techniques. Natural Hazards, [S. l.], v. 105, n. 1, p. 983-1012, 2021. DOI: 10.1007/s11069-020-04346-5. Disponível em: http://link.springer.com/10.1007/s11069-020-04346-5.

ARAUJO FILHO, H. A.; CRUZ, Paulo Teixeira Da; MASSAD, Faiçal; KANJI, Milton Assis. Debris flow as natural hazards affecting a large refinery at Cubatão, S.Paulo, Brazil (1998). In: WORLD CLEAN AIR AND ENVIRONMENT CONGRESS 1998, Anais [...]. [s.1: s.n.]

AUGUSTO FILHO, O. O estudo das corridas de massa em regiões serranas tropicais: um exemplo de aplicação no município de Ubatuba, SP. In: $7^{\circ}$ CONGRESSO BRASILEIRO DE GEOLOGIA DE ENGENHARIA 1993, Anais [...]. [s.l: s.n.] p. 63-70.

AVELAR, André S.; NETTO, Ana L. Coelho; LACERDA, Willy A.; BECKER, Leonardo B.; MENDONÇA, Marcos B. Mechanisms of the Recent Catastrophic Landslides in the Mountainous Range of Rio de Janeiro, Brazil. In: Landslide Science and Practice. Berlin, Heidelberg: Springer Berlin Heidelberg, 2013. p. 265-270. DOI: 10.1007/978-3-642-313370_34. Disponível em: http://link.springer.com/10.1007/978-3-642-31337-0_34.

BARRA ROCHA, C. H. ..; VASCONCELOS, D. ..; SOUZA, L. V. ..; SILVEIRA, F. J. ..; 
MACHADO, M. M. M.; ALMEIDA, L. L. Comparação de modelos digitais de elevação obtidos a partir de diferentes bases de dados - curvas de nível e pontos cotados IBGE, LIDAR, SRTM e ALOS. In: ANAIS DO XXVII CONGRESSO BRASILEIRO DE CARTOGRAFIA E XXVI EXPOSICARTA 6 A 9 DE NOVEMBRO DE 2017 2017, Anais [...]. [s.l: s.n.] p. $1302-1306$.

BIGARELLA, J. J.; KLEIN, R. M.; LANGE, R. B.; LOYOLA E SILVA, J.; LARACH, J. O. I.; RAUEN, M. J. A Serra do Mar e a porção oriental do estado do Paraná: um problema de segurança ambiental e nacional. Curitiba: Secretaria de Estado do Planejamento ADEA (Associação de Defesa e Educação Ambiental), 1978.

BITAR, O. Y. (Coord). et al. Cartas de suscetibilidade a movimentos gravitacionais - Nota técnica explicativa. São Paulo, SP / Brasília, DF.

BLUM, C. T. A. A Floresta Ombrófila Densa na Serra da Prata, Parque Nacional SaintHilaire/Lange, PR - Caracterização Florística, Fitossociológica e Ambiental de um Gradiente Altitudinal. 2006. Universidade Federal do Paraná, [S. l.], 2006.

BLUM, Christopher Thomas; RODERJAN, Carlos Vellozo; GALVÃO, Franklin. O Clima e sua influência na distribuição da floresta ombrófila densa na Serra da Prata, Morretes, Paraná. Floresta, [S. l.], v. 41, n. 3, 2011. DOI: 10.5380/rf.v41i3.24052. Disponível em: http://revistas.ufpr.br/floresta/article/view/24052.

BORGA, Marco; STOFFEL, Markus; MARCHI, Lorenzo; MARRA, Francesco; JAKOB, Matthias. Hydrogeomorphic response to extreme rainfall in headwater systems: Flash floods and debris flows. Journal of Hydrology, [S. l.], v. 518, p. 194-205, 2014. DOI: 10.1016/j.jhydrol.2014.05.022.

Disponível

em:

http://dx.doi.org/10.1016/j.jhydrol.2014.05.022.

BREIEN, Hedda; DE BLASIO, Fabio V.; ELVERHØI, Anders; HØEG, Kaare. Erosion and morphology of a debris flow caused by a glacial lake outburst flood, Western Norway. Landslides, [S. l.], v. 5, n. 3, p. 271-280, 2008. DOI: 10.1007/s10346-008-0118-3. Disponível em: http://link.springer.com/10.1007/s10346-008-0118-3.

BRITO, Thábata T.; OLIVEIRA-JÚNIOR, José F.; LYRA, Gustavo B.; GOIS, Givanildo; ZERI, Marcelo. Multivariate analysis applied to monthly rainfall over Rio de Janeiro state, Brazil. Meteorology and Atmospheric Physics, [S. l.], v. 129, n. 5, p. 469-478, 2017. DOI: 10.1007/s00703-016-0481-x. Disponível em: http://link.springer.com/10.1007/s00703-0160481-x.

BROLlO, M. J.; SANTORO, J.; PENTEADO, D. R.; FERNANDES DA SILVA, P. C. RIBEIRO, R. R. Itaoca (SP): Histórico de acidentes e desastres relacionados a perigos geológicos. In: $14^{\circ}$ SIMPÓSIO DE GEOLOGIA DO SUDESTE 2015, Campos do Jordão, SP. Anais [...]. Campos do Jordão, SP p. 5.

CAROU, Camila Bertaglia; VIEIRA, Bianca Carvalho; MARTINS, Tiago Damas; GRAMANI, Marcelo Fischer. Inventário dos Escorregamentos da Bacia do Rio Gurutuba, Vale do Ribeira (SP). Geography Department University of Sao Paulo, [S. l.], n. spe, p. 172, 2017. DOI: 10.11606/rdg.v0ispe.133377. Disponível

em: http://www.revistas.usp.br/rdg/article/view/133377.

CENDERELLI, D. A.; STEVEN KITE, J. Geomorphic effects of large debris flows on channel morphology at North Fork Mountain, eastern West Virginia, USA. Earth Surface Processes 
and Landforms, [S. l.], v. 23, n. 1, p. 1-19, 1998. DOI: https://doi.org/10.1002/(SICI)10969837(199801)23:1<1::AID-ESP814>3.0.CO;2-3.

CERRI, L. E. S.; AMARAL, C. P. Riscos geológicos. In: OLIVEIRA, A. M. S.; BRITO, S. N. A. De (org.). Geologia de engenharia. São Paulo, SP: ABGE - CNPQ-FAPESP, 1998. p. 301310.

CERRI, Rodrigo Irineu; REIS, Fábio Augusto Gomes Vieira; GRAMANI, Marcelo Fischer; GABELINI, Beatriz Marques; ZAINE, José Eduardo; SISTO, Felipe Pereira; GIORDANO, Lucilia Do Carmo. Análise da influência de atributos fisiográficos e morfométricos na definição da suscetibilidade de bacias hidrográficas à ocorrência de corridas de massa. Geologia USP. Série Científica, [S. l.], v. 18, n. 1, p. 35, 2018. DOI: 10.11606/issn.2316-9095.v18-133737. Disponível em: https://www.revistas.usp.br/guspsc/article/view/144347.

CHEN, Chien-Yuan; YU, Fan-Chieh. Morphometric analysis of debris flows and their source areas using GIS. Geomorphology, [S. l.], v. 129, n. 3-4, p. 387-397, 2011. DOI: 10.1016/j.geomorph.2011.03.002.

Disponível em: http://dx.doi.org/10.1016/j.geomorph.2011.03.002.

CHRISTOFOLETTI, A. Geomorfologia. 2 ${ }^{\mathrm{a}}$ edição ed. São Paulo, SP: Editora Blucher, 1980.

CIIAGRO. Dados de Temperatura Média Mensal do Municípios de São Paulo. 2018. Disponível em: http://www.ciiagro.sp.gov.br/ciiagroonline/quadros/qtmedperiodo.asp.

COE, Jeffrey A.; BESSETTE-KIRTON, Erin; BRIEN, Dianne L.; REID, Mark E. Debris-flow growth in Puerto Rico during Hurricane Maria: Preliminary results from analyses of pre- and post-event lidar data. In: SCG-XIII INTERNATIONAL SYMPOSIUM ON LANDSLIDES 2021, Cartagena, Colombia. Anais [...]. Cartagena, Colombia p. 8. Disponível em: https://www.issmge.org/uploads/publications/105/106/ISL2020-7.pdf.

COELHO-NETTO, Ana Luiza; AVELAR, André S. de Souza; LACERDA, Willy Alvarenga. Landslides and Disasters in Southeastern and Southern Brazil. In: Developments in Earth Surface Processes. [s.1: s.n.]. v. 13p. 223-243. DOI: 10.1016/S0928-2025(08)10012-8. Disponível em: https://linkinghub.elsevier.com/retrieve/pii/S0928202508100128.

COELHO-NETTO, Ana Luiza; SATO, Anderson Mululo; DE SOUZA AVELAR, André; VIANNA, Lílian Gabriela G.; ARAÚJO, Ingrid S.; FERREIRA, David L. C.; LIMA, Pedro H.; SILVA, Ana Paula A.; SILVA, Roberta P. January 2011: The Extreme Landslide Disaster in Brazil. In: Landslide Science and Practice. Berlin, Heidelberg: Springer Berlin Heidelberg, 2013. p. 377-384. DOI: 10.1007/978-3-642-31319-6_51. Disponível em: http://link.springer.com/10.1007/978-3-642-31319-6_51.

CORRÊA, C. V. S. Modelagem morfométrica para avaliação da potencialidade de bacias hidrográficas a corridas de detritos: proposta aplicada em Caraguatatuba (SP) e São Sebastião (SP). 2018. Universidade Estadual Paulista, [S. l.], 2018.

CORRÊA, C. V. S.; REIS, F. A. G. V.; AMARAL, A. M. C.; COURA, M. M.; GIORDANO, L. C.; CHAVES, C. J. Caracterização geológico-geomorfológica dos principais movimentos de massa na região sudeste do Brasil entre os anos de 1967 e 2011 como subsídio a estudos de retroanálise. In: $15^{\circ}$ CONGRESSO BRASILEIRO DE GEOLOGIA DE ENGENHARIA E AMBIENTAL 2015, Anais [...]. [s.l: s.n.] p. 10.

COSTA, J. E. Physical geomorphology of debris flows. In: COSTA, J. E.; FLEISHER, J. P. 
(org.). Developments and applications of geomorphology. New York: Springer-Verlag, 1984. p. $268-317$.

COUSSOT, P.; MEUNIER, M. Recognition, classification and mechanical description of debris flows. Earth-Science Reviews, [S. l.], v. 40, p. 209-227, 1995. DOI: 10.1016/00128252(95)00065-8.

CROZIER, M. J. Landslides: Causes, Consequences and Environment. London, UK: Croom Helm, 1986.

CRUZ, O. A serra do mar e o litoral na área de Caraguatatuba - SP - Contribuição à Geomorfologia Litorânea Tropical. 1974. Universidade de São Paulo, [S. l.], 1974.

CUI, P.; ZHOU, Gordon G. D.; ZHU, X. H.; ZHANG, J. Q. Scale amplification of natural debris flows caused by cascading landslide dam failures. Geomorphology, [S. l.], v. 182, p. 173-189, 2013. DOI: 10.1016/j.geomorph.2012.11.009. Disponível em: https://linkinghub.elsevier.com/retrieve/pii/S0169555X12005296.

DAEE, Departamento de Águas e Energia Elétrica. Banco de Dados Hidrológicos dos Municípios de São Paulo. 2018. Disponível em: http://www.hidrologia.daee.sp.gov.br/.

DE PLOEY, J.; CRUZ, O. Landslides in the Serra do Mar, Brazil. CATENA, [S. l.], v. 6, n. 2, p. 111-122, 1979. DOI: 10.1016/0341-8162(79)90001-8. Disponível em: https://linkinghub.elsevier.com/retrieve/pii/0341816279900018.

DE SCALLY, F. A. ..; OWENS, I. F. ..; LOUIS, J. .. Controls on fan depositional processes in the schist ranges of the Southern Alps, New Zealand, and implications for debris-flow hazard assessment. Geomorphology, [S. l.], v. 122, n. 1, p. 99-116, 2010. DOI: https://doi.org/10.1016/j.geomorph.2010.06.002.

DE SCALLY, Fes; SLAYMAKER, Olav; OWENS, Ian. Morphometric controls and basin response in the cascade mountains. Geografiska Annaler: Series A, Physical Geography, [S. l.], v. 83, n. 3, p. 117-130, 2001. DOI: 10.1111/j.0435-3676.2001.00148.x. Disponível em: https://www.tandfonline.com/doi/full/10.1111/j.0435-3676.2001.00148.x.

DIAS, Helen Cristina; GRAMANI, Marcelo Fischer; GROHMANN, Carlos Henrique; BATEIRA, Carlos Valdir de Meneses; VIEIRA, Bianca Carvalho. Statistical-based shallow landslide susceptibility assessment for a tropical environment: a case study in the southeastern Brazilian coast. Natural Hazards, [S. l.], 2021. a. DOI: 10.1007/s11069-021-04676-y. Disponível em: http://link.springer.com/10.1007/s11069-021-04676-y.

DIAS, V. C.; VIEIRA, B. C.; GRAMANI, M. F. Parâmetros morfológicos e morfométricos como indicadores da magnitude das corridas de detritos na Serra do Mar Paulista. Confins, [S. l.], v. 29, n. 29, p. 1-29, 2016. DOI: 10.4000/confins.11444. Disponível em: http://confins.revues.org/11444.

DIAS, Vivian Cristina. Corridas de detritos na Serra do Mar Paulista: parâmetros morfológicos e índice de potencial de magnitude e suscetibilidade. 2017. Universidade de São Paulo, São Paulo, 2017. DOI: 10.11606/D.8.2018.tde-02022018-120009. Disponível em: http://www.teses.usp.br/teses/disponiveis/8/8135/tde-02022018-120009/.

DIAS, Vivian Cristina; GRAMANI, Marcelo Fischer; DIAS, Helen Cristina; VIEIRA, Bianca Carvalho. Debris flows in a tropical environment: relation between magnitude, deposits and watershed morphometry. In: SCG-XIII INTERNATIONAL SYMPOSIUM ON 
LANDSLIDES 2021b, Cartagena, Colombia. Anais [...]. Cartagena, Colombia p. 8.

DOTSEVA, Z.; GERDJIKOV, I. Assessment of debris flows-prone watersheds in southern slopes of Stara Planina Mountain by combined raster and morphometric analysis. Journal of Mining and Geological Sciences, [S. l.], v. 63, p. 302-307, 2020.

EGG, G. C. ..; JUNIOR, J. G. ..; GLERIANI, J. M. ..; MEDEIROS, N. G. Geração de Modelos Digitais de Superfície empregando imagens do Sensor PRISM/ALOS - Estudo de caso para região da Zona da Mata de Minas Gerais. In: XVII SIMPÓSIO BRASILEIRO DE SENSORIAMENTO REMOTO 2015, João Pessoa, PB. Anais [...]. João Pessoa, PB p. 70577064.

EISBACHER, G. H. ..; CLAGUE, J. J. Destructive mass movements in high mountains: hazard and management. [s.l.] : Geological Survey of Canada, 1984.

ESTADÃO. Serra interditada. [S. l.], 2013. Disponível em: https://fotos.estadao.com.br/galerias/cidades,mulher-morre-e-24-veiculos-sao-atingidos-emdeslizamento-na-imigrantes, 8235,187801 .

FALEIROS, F. M.; MORAIS, S. M.; VICENTE, S. C. Geologia e recursos minerais da Folha Apiaí - SG.22-X-BV. São Paulo. Disponível em: http://rigeo.cprm.gov.br/xmlui/handle/doc/11366.

FARIA, D. G. M.; SANTORO, J.; TOMINAGA, L. K.; BROLLO, M. J.; SILVA, P. F.; RIBEIRO, R. R. Relatório do atendimento emergencial realizado pelo Instituto Geológico em Santa Catarina em razão do desastre ocorrido em novembro de 2008. [s.l: s.n.].

FERNANDES, Nelson F.; GUIMARÃES, Renato F.; GOMES, Roberto A. T.; VIEIRA, Bianca C.; MONTGOMERY, David R.; GREENBERG, Harvey. Topographic controls of landslides in Rio de Janeiro: field evidence and modeling. CATENA, [S. l.], v. 55, n. 2, p. 163-181, 2004. DOI: $\quad 10.1016 / \mathrm{S} 0341-8162(03) 00115-2 . \quad$ Disponível em: https://linkinghub.elsevier.com/retrieve/pii/S0341816203001152.

GABET, Emmanuel J.; BOOKTER, Andy. A morphometric analysis of gullies scoured by postfire progressively bulked debris flows in southwest Montana, USA. Geomorphology, [S. l.], v. 96, n. 3-4, p. 298-309, 2008. DOI: 10.1016/j.geomorph.2007.03.016. Disponível em: https://linkinghub.elsevier.com/retrieve/pii/S0169555X07001870.

GARCÍA-DELGADO, Helbert; MACHUCA, Silvia; MEDINA, Enif. Dynamic and geomorphic characterizations of the Mocoa debris flow (March 31, 2017, Putumayo Department, southern Colombia). Landslides, [S. l.], v. 16, n. 3, p. 597-609, 2019. DOI: 10.1007/s10346-018-01121-3. Disponível em: http://link.springer.com/10.1007/s10346-01801121-3.

GARCÍA-MARTÍNEZ, Reinaldo; LÓPEZ, José Luis. Debris flows of December 1999 in Venezuela. In: HUNGR, O. ..; JAKOB, Matthias (org.). Debris-flow Hazards and Related Phenomena. Berlin, Heidelberg: Springer Berlin Heidelberg, 2005. p. 519-538. DOI: 10.1007/3-540-27129-5_20. Disponível em: http://link.springer.com/10.1007/3-540-271295_20.

GARCIA, M. H. Sediment transport and morphodynamics. In: GARCÍA, M. H. (org.). Sedimentation engineering: processes, measurements, modeling, and practice. [s.l.] : Virginia: ASCE, 2008. p. 1132. 
GOMES, Maria Carolina Villaça. Corridas de detritos e as taxas de denudação a longotermo da Serra do Mar/SP. 2016. Universidade de São Paulo, [S. l.], 2016.

GOMES, Roberto A. T.; GUIMARÃES, Renato F.; CARVALHO, Osmar A.; FERNANDES, Nelson F.; VARGAS, Eurípedes A.; MARTINS, Éder S. Identification of the affected areas by mass movement through a physically based model of landslide hazard combined with an empirical model of debris flow. Natural Hazards, [S. l.], v. 45, n. 2, p. 197, 2008. DOI: 10.1007/s11069-007-9160-z. Disponível em: http://link.springer.com/10.1007/s11069-0079160-z.

GOMES, Roberto; GUIMARÃES, Renato; DE CARVALHO, JÚNIOR, Osmar; FERNANDES, Nelson; DO AMARAL JÚNIOR, Eurípedes. Combining Spatial Models for Shallow Landslides and Debris-Flows Prediction. Remote Sensing, [S. l.], v. 5, n. 5, p. 22192237, 2013. DOI: 10.3390/rs5052219. Disponível em: http://www.mdpi.com/2072$4292 / 5 / 5 / 2219$.

GRAMANI, M. F.; ARDUIN, D. H. Morfologia dos Depósitos de Debris Flow de Itaoca, São Paulo. In: $15^{\circ}$ CONGRESSO BRASILEIRO DE GEOLOGIA DE ENGENHARIA E AMBIENTAL 2015, Bento Gonçalves, RS. Anais [...]. Bento Gonçalves, RS p. 1-10.

GRAMANI, M. F.; GOMES, C. L. R.; OGURA, A. T.; GOMES, L. A.; SILVA, F. C.; MIRAMBOLA, F. A. Processos e cenários de risco identificados durante as ações desenvolvidas na região do Vale do Itajaí - SC em 2008. In: V CONFERÊNCIA BRASILEIRA DE ESTABILIDADE DE ENCOSTAS (COBRAE 2009) 2009, São Paulo, SP. Anais [...]. São Paulo, SP p. 11.

GRAMANI, M. F.; MARTINS, V. T. S. Debris flows occurrence by intense rains on January 13, 2014 at Itaoca city, São Paulo, Brazil: Impacts and Field observations. In: Landslides and Engineered Slopes. Experience, Theory and Practice. [s.1.] : CRC Press, 2016. v. 2p. 10111019. DOI: 10.1201/9781315375007-110. Disponível em: https://www.taylorfrancis.com/books/9781498788076/chapters/10.1201/9781315375007-110.

GRAMANI, Marcelo Fischer. A corrida de detritos (debris flow) no Ribeirão do Cágado, Serra do Mar, Município de Cubatão, SP. In: CONFERÊNCIA BRASILEIRA DE ESTABILIDADE DE ENCOSTAS (VI COBRAE) 2013, Angra dos Reis, RJ. Anais [...]. Angra dos Reis, RJ p. $1265-1272$.

GRAMANI, Marcelo Fischer. A corrida de massa no Córrego Guarda-mão, município de Itaoca (SP): Impactos e observações de campo. In: $15^{\circ}$ CONGRESSO BRASILEIRO DE GEOLOGIA DE ENGENHARIA E AMBIENTAL 2015, Anais [...]. [s.l: s.n.] p. 1-10.

GRAMANI, Marcelo Fischer. Caracterização Geológico-Geotécnica das Corridas de Detritos ("Debris Flows") no Brasil e comparação com alguns casos internacionais. 2001a. Universidade de São Paulo, [S. l.], 2001.

GRAMANI, Marcelo Fischer. Caracterização geológico-geotécnica das corridas de detritos ("Debris Flows") no Brasil e comparação com alguns casos internacionais. 2001b. Universidade de São Paulo, [S. l.], 2001.

GRAMANI, Marcelo Fischer; OLIVITO, J. P. R.; AUGUSTO FILHO, O.; MAGALHÃES, F. S. Análise da potencialidade de geração de corridas de massa nos trechos serranos do duto OSBAT. In: ANAIS DO $11^{\circ}$ CONGRESSO BRASILEIRO DE GEOLOGIA DE ENGENHARIA E AMBIENTAL 2005, Florianópolis. Anais [...]. Florianópolis: ABGE- 
Associação Brasileira de Geologia de Engenharia, 2005. p. 15.

GUIDICINI, G.; NIEBLE, C. M. Estabilidade de Taludes Naturais e de Escavação. 2. ed. São Paulo: Editora Blücher, 1984.

HADLEY, R.; SCHUMM, S. Sediment Sources and Drainage Basin Characteristics in Upper Cheyenne River Basin. Washington, DC.

HORTON, R. E. Erosional development of streams and their drainage basins; Hydrophysical approach to quantitative morphology. Bulletin of the Geological Society of America, [S. l.], v. 56, n. March, p. 275-370, 1945.

HUEBL, J. ..; FIEBIGER, G. Debris-flow mitigation measures. In: JAKOB, M. AND HUNGR, O. (org.). Debris-flow hazards and related phenomena. [s.l.] : Springer, 2005. p. 445 - 488.

HUNGR, O.; MCDOUGALL, S.; BOVIS, M. Entrainment of material by debris flows. In: JAKOB, M.; HUNGR, O. (org.). Debris-flow hazards and related phenomena. [s.l.] : Springer, 2005. p. $135-158$.

HUNGR, Oldrich; CLAGUE, John; MORGENSTERN, N. R.; VANDINE, Doug; STADEL, Darren. A review of landslide risk acceptability practices in various countries. Landslides and Engineered Slopes. Experience, Theory and Practice, [S. l.], v. 2, p. 1121-1128, 2016. DOI: 10.1201/b21520-135.

HUNGR, Oldrich; EVANS, S. G.; BOVIS, M. J.; HUTCHINSON, J. N. A review of the classification of landslides of the flow type. Environmental and Engineering Geoscience, [S l.], v. 7, n. 3, p. 221-238, 2001. DOI: 10.2113/gseegeosci.7.3.221. Disponível em: https://pubs.geoscienceworld.org/aeg/eeg/article/7/3/221/60609/A-review-of-the-

classification-of-landslides-of.

HUNGR, Oldrich; LEROUEIL, Serge; PICARELLI, Luciano. The Varnes classification of landslide types, an update. Landslides, [S. l.], v. 11, n. 2, p. 167-194, 2014. DOI: 10.1007/s10346-013-0436-y.

IBGE， INSTITUTO BRASILEIRO DE GEOGRAFIA E. ESTATÍSTICA. Avaliação Planialtimétrica de Dados ALOS/PRISM Estudo de Caso: Itaguaí - RJ. Rio de Janeiro, RJ.

IBGE, INSTITUTO BRASILEIRO DE GEOGRAFIA E. ESTATÍSTICA. Cidades. 2018. Disponível em: https://cidades.ibge.gov.br/.

IKEYA, H. A method of designation for area in danger of debris flowErosion and Sediment Transport in Pacific Rim Steeplands. IAHS Publication No. 132. Wallingford, UK.

ILINCA, Viorel. Using morphometrics to distinguish between debris flow, debris flood and flood (Southern Carpathians, Romania). CATENA, [S. l.], v. 197, p. 104982, 2021. DOI: 10.1016/j.catena.2020.104982. Disponível

https://linkinghub.elsevier.com/retrieve/pii/S0341816220305324.

INSTITUTO FLORESTAL DO ESTADO DE SÃO PAULO, IFSP. Inventário Florestal da Vegetação Nativa do Estado de São Paulo. 2009. Disponível em: https://smastr16.blob.core.windows.net/sifesp/2013/12/mapainventario.pdf.

IPT. Mapa Geomorfológico do Estado de São Paulo. São Paulo. 
IPT. Instabilidade das encostas da Serra do Mar voltadas ao parque industrial de Cubatão (SP): diagnose, soluções e ações de emergência. São Paulo.

IPT. Reconhecimento, caracterização e monitoramento de locais potencialmente sujeitos a instabilizações na Serra do Mar na área de influência dos diversos sistemas de captação e abastecimento de água de tratamento de estogo. São Paulo, SP.

ITCG, Instituto de Terras Cartografia e Geologia do Paraná. Mapeamento Geológico do Paraná, escala 1:250.000 - Folha Curitiba SG-22-X-D. [s.l: s.n.]. Disponível em: http://www.itcg.pr.gov.br/modules/faq/category.php?categoryid=9\#.

ITCG, Instituto de Terras Cartografia e Geologia do Paraná. Solos - Estado do Paraná. Escala 1:2.000.000. [s.l: http://www.itcg.pr.gov.br/arquivos/File/Produtos_DGEO/Mapas_ITCG/PDF/Mapa_Solos.pdf

ITCG, Instituto de Terras Cartografia e Geologia do Paraná. Formações Fitogeográficas Estado do Paraná. Escala 1:2.000.000. [s.l: s.n.]. Disponível em: http://www.itcg.pr.gov.br/arquivos/File/Produtos_DGEO/Mapas_ITCG/PDF/Mapa_Fitogeogr afico_A3.pdf.

IVERSON, Richard M. The physics of debris flows. Review of Geophysics, [S. l.], v. 35, n. 97, p. 245-296, 1997.

JACKSON, Lionel E.; KOSTASCHUK, R. A.; MACDONALD, G. M. Identification of debris flow hazard on alluvial fans in the Canadian Rocky Mountains. GSA Reviews in Engineering Geology, [S. l.], v. 7, n. November, p. 115-124, 1987. DOI: 10.1130/REG7-p115.

JAKOB, M.; HUNGR, O. Introduction. In: JAKOB, M. HUNGR, O. (org.). Debris-flow hazards and related phenomena. [s.1.] : Springer, 2005. p. 1-7.

JAKOB, Matthias. Morphometric and Geotechnical Controls of Debris Flow Frequency and Magnitude in Southwestern British Columbia. 1996. University of British Columbia, [S. l.], 1996. DOI: 10.14288/1.0087740.

JAKOB, Matthias. Debris-flow hazard analysis. In: JAKOB, M.; HUNGR, O. (org.). Debrisflow hazards and related phenomena. [s.1.] : Springer, 2005. a. p. $442-474$.

JAKOB, Matthias. A size classification for debris flows. Engineering Geology, [S. l.], v. 79, n. 3-4, p. 151-161, 2005. b. DOI: 10.1016/j.enggeo.2005.01.006. Disponível em: https://linkinghub.elsevier.com/retrieve/pii/S0013795205000177.

JAKOB, Matthias; OWEN, T.; SIMPSON, T. A regional real-time debris-flow warning system for the District of North Vancouver, Canada. Landslides, [S. l.], v. 9, n. 2, p. 165-178, 2012. DOI: 10.1007/s10346-011-0282-8. Disponível em: http://link.springer.com/10.1007/s10346011-0282-8.

JAPAN AEROSPACE EXPLORATION AGENCY (JAXA) AND EARTH OBSERVATION RESEARCH AND APPLICATION CENTER (EORC). ALOS Data Users Handbook. $\begin{array}{lllll}\text { Revision } & \mathrm{C} & \text { ed. } & \text { s.n.]. } & \text { DOI: }\end{array}$ https://www.eorc.jaxa.jp/ALOS/en/doc/fdata/ALOS_HB_RevC_EN.pdf. Disponível em: https://www.eorc.jaxa.jp/ALOS/en/doc/fdata/ALOS_HB_RevC_EN.pdf.

JICA, Japan International Cooperation Agency. The Study on the Disaster Prevention and 
Restoration Project in Serra do Mar, Cubatão Region, S. Paulo. [s.l: s.n.].

JOHNSON, A. M. Physical Processes in Geology. A method for interpretation of natural phenomena - intrusions in igneous rocks, fractures and folds, flow of debris and ice. San Francisco, CA: Freeman, Cooper \& Company, 1970.

JOHNSON, Peggy A.; MCCUEN, Richard H.; HROMADKA, Theodore V. Magnitude and frequency of debris flows. Journal of Hydrology, [S. l.], v. 123, n. 1-2, p. 69-82, 1991. DOI: 10.1016/0022-1694(91)90069-T. Disponível

em: https://linkinghub.elsevier.com/retrieve/pii/002216949190069T.

JONES, Fred O. Landslides of Rio de Janeiro and the Serra das Araras escarpment, BrazilUnited States Government Printing Office. Washington, DC. Disponível em: http://pubs.er.usgs.gov/publication/pp697.

KANJI, M. A.; CRUZ, P. T.; MASSAD, F.; ARAÚJO FILHO, H. A. Basic and Common Characteristics of Debris Flows. In: II PANAMERICAN SYMPOSIUM ON LANDSLIDES / II COBRAE 1997, Rio de Janeiro, RJ. Anais [...]. Rio de Janeiro, RJ p. 232-240.

KANJI, M. A.; MASSAD, F.; CRUZ, P. T. Debris Flows in Areas of Residual Soils: Occurrence and Characteristics. In: INTERNATIONAL WORKSHOP ON OCCURRENCE AND MECHANISM OF FLOWS IN NATURAL SLOPES AND EARTHFILLS, 2003, Napoles. Anais [...]. Napoles: Associacione Geotecnica Italiana, 2003. p. 1-9.

KANJI, M. A.; MASSAD, F.; GRAMANI, M. F.; CRUZ, P. T. Debris Flows (fluxos de detritos). In: GUNTER, W. M. R.; CICCOTTI, L.; RODRIGUES, A. C. (org.). Desastres Múltiplas abordagens e desafios. Rio de Janeiro, RJ: Elsevier, 2017. p. 183-210.

KANJI, Milton A. ..; GRAMANI, M. F. Metodologia para determinação da vulnerabilidade a corridas de detritos em pequenas bacias hidráulicas. In: III CONFERÊNCIA BRASILEIRA DE ESTABILIDADE DE ENCOSTAS (III COBRAE) 2001, Rio de Janeiro, RJ. Anais [...]. Rio de Janeiro, RJ

KANJI, Milton A.; CRUZ, Paulo T.; MASSAD, Faiçal. Debris flow affecting the Cubatão Oil Refinery, Brazil. Landslides, [S. l.], v. 5, n. 1, p. 71-82, 2008. DOI: 10.1007/s10346-0070110-3.

KEAN, J. W. et al. Inundation, flow dynamics, and damage in the 9 January 2018 Montecito debris-flow event, California, USA: Opportunities and challenges for post-wildfire risk assessment. Geosphere, [S. l.], v. 15, n. 4, p. 1140-1163, 2019. DOI: 10.1130/GES02048.1. Disponível em: https://pubs.geoscienceworld.org/gsa/geosphere/article/15/4/1140/571496/Inundation-flowdynamics-and-damage-in-the- 9 .

KING, J. Tsing Shan Debris Flow (Special Project Report SPR 6/96). Hong Kong.

KOBIYAMA, M.; MICHEL, G. P. Bibliografia dos trabalhos de fluxos de detritos ocorridos no Brasil no período de 1949-2014. [s.l: s.n.].

KOPPEN, W. Das Geographische System der Klimate. Handbuch der Klimatologie (The Geographical System of the Climate, Handbook of Climatology). Berlin: Gerbrüder Bornträger, 1936.

KOVANEN, Dori J.; SLAYMAKER, Olav. The morphometric and stratigraphic framework 
for estimates of debris flow incidence in the North Cascades foothills, Washington State, USA. Geomorphology, $\quad[S . \quad$ l. $], \quad$ v. $99, \quad$ n. 1-4, p. 224-245, 2008. DOI: 10.1016/j.geomorph.2007.11.003. Disponível em: https://linkinghub.elsevier.com/retrieve/pii/S0169555X07005181.

LEE, Su-Gon; WINTER, Mike G. The effects of debris flow in the Republic of Korea and some issues for successful risk reduction. Engineering Geology, [S. l.], v. 251, p. 172-189, 2019. DOI: $\quad$ 10.1016/j.enggeo.2019.01.003. https://linkinghub.elsevier.com/retrieve/pii/S0013795218319045.

Disponível

em:

LIMA, Ingrid Ferreira; FERNANDES, Nelson Ferreira; VARGAS JUNIOR, Eurípedes Do Amaral. Análise morfométrica em bacias afetadas por fluxos de detritos na Região Serrana do Rio de Janeiro. Revista Brasileira de Geomorfologia, [S. l.], v. 21, n. 2, 2020. DOI: 10.20502/rbg.v21i2.1515. Disponível

em: http://www.lsie.unb.br/rbg/index.php/rbg/article/view/1515.

MAACK, R. Breves notícias sobre a Geologia dos Estados do Paraná e Santa Catarina. Arquivos de Biologia e Tecnologia, [S. l.], v. 2, p. 66-154, 1947.

MARCHI, L.; PASUTO, A.; TECCA, P. R. Flow processes on alluvial fans in the eastern Italian Alps. Zeitschrift fur Geomorphologie, [S. l.], v. 37, n. 4, p. 447-458, 1993.

MARCHI, Lorenzo; ARATTANO, Massimo; DEGANUTTI, Andrea M. Ten years of debrisflow monitoring in the Moscardo Torrent, Italian Alps. Geomorphology, [S. l.], v. 46, p. 1-17, 2002. DOI: https://doi.org/10.1016/S0169-555X(01)00162-3.

MARRA, Francesco; NIKOLOPOULOS, Efthymios I.; CREUTIN, Jean Dominique; BORGA, Marco. Radar rainfall estimation for the identification of debris-flow occurrence thresholds. Journal of Hydrology, $[S . \quad l],$.$\quad v. 519, p. 1607-1619, 2014. DOI:$ 10.1016/j.jhydrol.2014.09.039. Disponível https://linkinghub.elsevier.com/retrieve/pii/S0022169414007215.

MARTINS, A.; FERREIRA, M. B. P.; PONTONI, D. R.; BATISTA, A. H.; PASSO, E. Descrição da compartimentação de processos de movimentos de massa na Serra da Prata em Morretes - PR. In: ANAIS DO $9^{\circ}$ SINAGEO - SIMPÓSIO NACIONAL DE GEOMORFOLOGIA 2012, Rio de Janeiro, RJ. Anais [...]. Rio de Janeiro, RJ p. 4.

MATOS, Luzia de Jesus; FERREIRA, Claudio José; BATEIRA, Carlos V. M.; CARVALHO VIEIRA, Bianca. Avaliação das Construções Danificadas por Corridas de Detritos e Inundações Bruscas no Vale do Ribeira (SP) em 2014. Revista do Departamento de Geografia, [S. l.], v. Volume Esp, p. 11, 2018. DOI: 10.11606/rdg.v0ispe.144423.

MAUNSELL GEOTECHNICAL SERVICES LTD. Detailed study of the 1 September 2001 debris flow on the natural hillside above Lei Pui street. (Geo Report $\mathbf{n}^{\circ}$ 154). Hong Kong.

MCDOUGALL, Scott; HUNGR, Oldrich. Dynamic modelling of entrainment in rapid landslides. Canadian Geotechnical Journal, [S. l.], v. 42, n. 5, p. 1437-1448, 2005. DOI: 10.1139/t05-064.

MELLO, I. S. C. Geologia e estudo metalogenético do maciço Itaóca, Vale do Ribeira, SP e PR. 1995. Universidade de São Paulo, [S. l.], 1995.

MELO, M. S.; GUIMARÃES, G. B.; RAMOS, A. F.; PRIETO, C. C. Relevo e hidrografia dos Campos Gerais. In: MELO, M. S. De; MORO, R. S.; GUIMARÃES, G. B. (org.). Patrimônio 
natural dos Campos Gerais. Ponta Grossa, PR: Editora UEPG, 2014. p. 50-59.

NERY, Tulius Dias. Dinâmica das corridas de detritos no Litoral Norte de São Paulo. 2016. Universidade de São Paulo, [S. l.], 2016.

NIKOLOVA, V.; KAMBUROV, A.; RIZOVA, R. Morphometric analysis of debris flows basins in the Eastern Rhodopes (Bulgaria) using geospatial technologies. Natural Hazards, [S. l.], v. 1-17, 2020. DOI: 10.1007/s11069-020-04301-4.

OKA-FIORI, C.; SANTOS, L. J. C.; CANALI, N. E.; FIORI, A. P.; SILVEIRA, C. T.; SILVA, J. M. F.; ROSS, J. L. S. Atlas Geomorfológico do Estado do Paraná: escala base 1:250.000, modelos reduzidos 1:500.000. Curitiba, PR: Minerais do Paraná - MINEROPAR, 2006.

PEARSON, K. On the General Theory of Skew Correlation and Non-linear Regression. London, UK: Dulau and Company, 1905.

PERrotTA, M. M. et al. Mapa Geológico do Estado de São Paulo, escala 1:750.000. São Paulo, SP.

PETRI, S.; SUGUIO, K. Características granulométrica dos materiais de escorregamentos de Caraguatatuba, São Paulo, como subsídio para o estudo da sedimentação neocenozóica do Sudeste Brasileiro. In: $25^{\circ}$ CONGRESSO BRASILEIRO DE GEOLOGIA, BOLETIM ESPECIAL 1971, São Paulo, SP. Anais [...]. São Paulo, SP p. 199 - 200.

PICANÇO, J. L.; TANAKA, H. S.; MESQUITA, M. J.; COSTA, V. V.; LUIZ, E. F. O.; LOPES, A. B. B.; AFONSO, F. K.; PIMENTA, V. Debris flow hazard zonation in Serra da Prata range, Paraná State, Brazil: Watershed morphometric constraints. In: Landslides and Engineered Slopes. Experience, Theory and Practice. [s.1.] : CRC Press, 2016. p. 16131619. DOI: 10.1201/9781315375007-189. Disponível em: https://www.taylorfrancis.com/books/9781498788076/chapters/10.1201/9781315375007-189.

PIERSON, Thomas C. Flow behavior of channelized debris flows, Mount St. Helens, Washington. In: ABRAHAMS, A. D. (org.). Hillslope Processes. 1st Editio ed. London, UK: Routledge, 1986. p. 434.

PIRULLI, M.; PASTOR, M. Numerical study on the entrainment of bed material into rapid landslides. Géotechnique, [S. l.], v. 62, n. 11, p. 959-972, 2012. DOI: 10.1680/geot.10.P.074. Disponível em: http://www.icevirtuallibrary.com/doi/10.1680/geot.10.P.074.

POLANCO, L. S. E. Correlações empíricas para fluxo de detritos. 2001. Universidade Federal do Rio de Janeiro, [S. l.], 2001.

PORTILLA, M.; CHEVALIER, G.; HÜRLIMANN, M. Description and analysis of the debris flows occurred during 2008 in the Eastern Pyrenees. Natural Hazards and Earth System Science, [S. l.], v. 10, n. 7, p. 1635-1645, 2010. DOI: 10.5194/nhess-10-1635-2010.

RICKENMANN, D. Empirical Relationships for debris flows. Natural Hazards, [S. l.], v. 19, p. $47-77,1999$.

RICKENMANN, Dieter; ZIMMERMANN, Markus. The 1987 debris flows in Switzerland: documentation and analysis. Geomorphology, [S. l.], v. 8, n. 2-3, p. 175-189, 1993. DOI: 10.1016/0169-555X(93)90036-2.

em:

https://linkinghub.elsevier.com/retrieve/pii/0169555X93900362. 
ROSS, J. L. S. A morfogênese da bacia do Ribeira do Iguape e os sistemas ambientais. GEOUSP: Espaço e Tempo (Online), [S. l.], v. 12, p. 21-46, 2002.

ROSSI, M. Mapa pedológico do Estado de São Paulo: revisado e ampliado. São Paulo. Disponível em: http://correiadasilvaadvogados.com/pdf/art_amb/art_amb2.pdf.

SAKAI, R. O. Estudo do impacto de Debris flows: caso da Bacia do Rio Santo Antônio em Caraguatatuba (Brasil). 2014. Universidade de São Paulo, [S. l.], 2014.

SAVAGE, W. ..; BAUM, R. Instability of steep slopes. In: JAKOB, M.; HUNGR, O. (org.). Debris-flow hazards and related phenomena. [s.1.] : Springer, 2005. p. $53-80$.

SELBY, M. J. Mass Wasting of Soils. In: Hillslope Materials and Processes. 2. ed. Oxford: Oxford University Press, 1993. p. 249-355.

SHAPIRO, S. S.; WILK, M. B. An Analysis of Variance Test for Normality (Complete Samples). Biometrika, $[S . \quad l],$.$\quad v. 52, n. \mathrm{N}^{\circ}$ 3/4, p. 591-611, 1965. DOI: https://doi.org/10.2307/2333709.

SHREVE, R. L. Statistical law of stream numbers. Journal of Geology, [S. l.], v. 74, p. 17 37, 1966.

SHREVE, R. L. Infinite topologically random channel networks. Journal of Geology, [S. l.], v. 75, p. $178-186,1967$.

SILVA, Wanderson Luiz; DERECZYNSKI, Claudine; CHANG, Manyu; FREITAS, Marcos; MACHADO, Bruno Justen; TRISTÃO, Leonardo; RUGGERI, Janaina. Tendências observadas em indicadores de extremos climáticos de temperatura e precipitação no estado do Paraná.

Revista Brasileira de Meteorologia, [S. l.], v. 30, n. 2, p. 181-194, 2015. DOI: 10.1590/0102778620130622.

http://www.scielo.br/scielo.php?script=sci_arttext\&pid=S0102-

$77862015000200181 \& \operatorname{lng}=$ pt\&tlng=pt.

SILVEIRA, Claudinei Taborda Da; FIORI, Alberto Pio; FERREIRA, Antonio Marcos; GÓIS, José Roberto De; MIO, Giuliano De; SILVEIRA, Ricardo Michael Pinheiro; MASSULINI, Nataniel Edgar Bassi; LEONARDI, Talita Mariana Herrig. Emprego de atributos topográficos no mapeamento da susceptibilidade a processos geoambientais na bacia do rio Jacareí, Paraná. Sociedade \& Natureza, [S. l.], v. 25, n. 3, p. 623-639, 2013. DOI: 10.1590/S198245132013000300014.

Disponível

http://www.scielo.br/scielo.php?script=sci_arttext\&pid=S1982-

45132013000300014\&lng=pt\&tlng=pt.

SILVEIRA, Ricardo Michael Pinheiro. Proposta metodológica para mapeamento geomorfológico com uso da análise digital do relevo no estado do Paraná. 2019. Universidade Federal do Paraná, [S. l.], 2019. Disponível em: https://acervodigital.ufpr.br/handle/1884/60699.

SIMONI, Alessandro; MAMMOLITI, Maria; BERTI, Matteo. Uncertainty of debris flow mobility relationships and its influence on the prediction of inundated areas. Geomorphology, [S. l.], v. 132, n. 3-4, p. 249-259, 2011. a. DOI: 10.1016/j.geomorph.2011.05.013. Disponível em: http://linkinghub.elsevier.com/retrieve/pii/S0169555X11002509.

SIMONI, Alessandro; MAMMOLITI, Maria; BERTI, Matteo. Uncertainty of debris flow mobility relationships and its influence on the prediction of inundated areas. Geomorphology, 
[S. l.], v. 132, $\quad$ n. 3-4, p. 249-259, 2011. b. DOI: https://doi.org/10.1016/j.geomorph.2011.05.013.

SLAYMAKER, Olav. Debris torrent hazard in Eastern Fraser and Coquihalla Valleys. Western Geography, [S. l.], v. 1, p. $34-48,1990$.

STERNBERG, H. O. Enchentes e movimentos coletivos do solo no Vale do Paraíba em dezembro de 1948 - Influência da exploração destrutiva das terras. Revista Brasileira de Geografia, [S. l.], v. 11, p. 223 - 261, 1949.

STOFFEL, Markus. Magnitude-frequency relationships of debris flows - A case study based on field surveys and tree-ring records. Geomorphology, [S. l.], v. 116, n. 1-2, p. 67-76, 2010. DOI: 10.1016/j.geomorph.2009.10.009. Disponível em: https://linkinghub.elsevier.com/retrieve/pii/S0169555X09004450.

STRAHLER, Arthur N. Hypsometric (area-altitude) analysis of erosional topography. Bulletin of the Geological Society of America, [S. l.], v. 63, n. 11, p. 1117-1142, 1952. DOI: 10.1130/0016-7606(1952)63[1117:HAAOET]2.0.CO;2.

STRAHLER, Arthur N. Quantitative analysis of watershed geomorphology. Transactions American Geophysical Union, $[S . \quad$ l. $], \quad$ v. $38, \quad$ p. 913-920, $1957 . \quad$ DOI: https://doi.org/10.1029/TR038i006p00913.

STRAHLER, Arthur N. Dimensional analysis applied to fluvial eroded landforms. Geological Society of America, [S. l.], v. 69, p. 279 - 300, 1958.

TAKAHASHI, T. Debris Flow. Rotterdam: Balkema, 1991.

TAKAHASHI, T. Debris Flow: mechanics, prediction and countermeasures. London, UK: Taylor \& Francis Group, 2007.

TATIZANA, C.; OGURA, A. T.; CERRI, L. E. S.; ROCHA, M. C. M. Modelamento numérico da análise de correlação entre chuvas e escorregamentos aplicado às encostas da Serra do Mar no município de Cubatão5 ${ }^{\circ}$ Congresso Brasileiro de Geologia de Engenharia, 1987.

TERASSI, P. M. B.; GALVANI, E. Identification of Homogeneous Rainfall Regions in the Eastern Watersheds of the State of Paraná, Brazil. Climate, [S. l.], v. 5, n. 3, p. 13, 2017. DOI: 10.3390/cli5030053. Disponível em: http://www.mdpi.com/2225-1154/5/3/53.

THURBER CONSULTANTS LTD. Debris Torrent and Flooding Hazards, Highway 99, Howe Sound. Victoria, BC.

TOMAZZOLI, E. R.; FLORES, J. A. A.; BAUZYS, F. Movimentos de massa ocorridos no evento de novembro de 2008, no entorno do Morro do Baú, Vale do Itajaí (SC): caracterização geológico-geomorfológica. In: V CONFERÊNCIA BRASILEIRA DE ESTABILIDADE DE ENCOSTAS (COBRAE 2009) 2009, Anais [...]. [s.l: s.n.] p. 10.

UJUETA, G.; MOJICA, J. Fotointerpretacion y observaciones del flujo de escombros de Noviembre 13 de 1985 en Armero (Tolima, Colombia). Geologia Colombiana, [S. l.], v. 1, p. 5-25, 1995.

VANDINE, D. F. Debris flows and debris torrents in the Southern Canadian Cordillera. Canadian Geotechnical Journal, [S. l.], v. 22, n. 1, p. 44-68, 1985. DOI: 10.1139/t85-006. 
Disponível em: http://www.nrcresearchpress.com/doi/10.1139/t85-006.

VANDINE, Doug. Debris flow control structures for forest enginnering. Victoria, BC.

VARNES, David J. Slope Movement Types and Processes. In: SCHUSTER, R. L.; KRIZEK, R. J. (org.). Special Report 176: Landslides: Analysis and Control. Washington, DC: Transportation and Road Research Board, National Academy of Science, 1978. p. 11-33.

VIEIRA, B. C.; GRAMANI, M. F. Serra do Mar: the most "tormented" relief in Brazil. In: VIEIRA, Bianca Carvalho; SALGADO, André Augusto Rodrigues; SANTOS, Leonardo José Cordeiro (org.). Landscapes and Landforms of Brazil. World Geomorphological Landscapes1. ed. Dordrecht: Springer Netherlands, 2015. p. 285 - 297. DOI: 10.1007/978-94017-8023-0. Disponível em: http://link.springer.com/10.1007/978-94-017-8020-9.

VIEIRA, B. C.; VIEIRA, A. C. F.; FERNANDES, N. F.; AMARAL, C. P. Estudo comparativo dos movimentos de massa ocorridos em fevereiro de 1996 nas bacias do Quitite e do Papagaio (RJ): Uma abordagem geomorfológica. In: 2ND. PAN-AMERICAN SYMPOSION ON LANDSLIDES/ 2ND. BRAZILIAN CONFERENCE ON SLOPE STABILITY. 1997, Anais [...]. [s.l: s.n.] p. 165-164.

VIEIRA, Bianca Carvalho; FERNANDES, Nelson Ferreira; AUGUSTO FILHO, Oswaldo; MARTINS, Tiago Damas; MONTGOMERY, David R. Assessing shallow landslide hazards using the TRIGRS and SHALSTAB models, Serra do Mar, Brazil. Environmental Earth Sciences, [S. l.], v. 77, n. 6, p. 260, 2018. DOI: 10.1007/s12665-018-7436-0. Disponível em: http://link.springer.com/10.1007/s12665-018-7436-0.

WELSH, Andrew; DAVIES, Tim. Identification of alluvial fans susceptible to debris-flow hazards. Landslides, [S. l.], v. 8, n. 2, p. 183-194, 2011. DOI: 10.1007/s10346-010-0238-4.

WIECZOREK, G. F.; GLADE, T. Climatic factors influencing occurrence of debris flow. In: JAKOB, M.; HUNGR, O. (org.). Debris-flow hazards and related phenomena. [s.1.] : Springer, 2005. p. $325-362$.

WILFORD, D. J.; SAKALS, M. E.; INNES, J. L.; SIDLE, R. C.; BERGERUD, W. A. Recognition of debris flow, debris flood and flood hazard through watershed morphometrics. Landslides, [S. l.], v. 1, n. 1, p. 61-66, 2004. DOI: 10.1007/s10346-003-0002-0. Disponível em: http://link.springer.com/10.1007/s10346-003-0002-0.

WORLD BANK. Lidando com perdas: Opções de proteção financeira contra desastres no Brasil. Washington DC. Disponível em: http://documents1.worldbank.org/curated/en/473501484214212075/pdf/111953-WP-

OpesdeProtecaoFinanceiradeRiscosdeDesastresnoBrasilPORTFINALWEB-PUBLICABSTRACT-SENT-PORTUGUESE.pdf.

XU, M. D.; FENG, Q. H. Roughness of debris flows. In: PROCEEDING OF THE FIRST CONFERENCE OF CHINESE RESEARCH OF DEBRIS FLOWS 1979, Anais [...]. [s.l: s.n.] p. 51-52.

ZAI, Clotilde; GRASSO, Lucélia; SILVEIRA, Claudinei Taborda Da; GUARNIERI, Doralice Palanicheski. Impactos socioambientais por movimentos de massa na comunidade de Floresta, região da Serra do Mar paranaense. Caminhos de Geografia, [S. l.], v. 18, n. 61, p. 19-32, 2017. DOI: 10.14393/RCG186102. Disponível em: http://www.seer.ufu.br/index.php/caminhosdegeografia/article/view/33245. 
ZHANG, H. Y.; SHI, Z. H.; FANG, N. F.; GUO, M. H. Linking watershed geomorphic characteristics to sediment yield: Evidence from the Loess Plateau of China. Geomorphology, [S. l.], v. 234, p. 19-27, 2015. DOI: 10.1016/j.geomorph.2015.01.014. Disponível em: https://linkinghub.elsevier.com/retrieve/pii/S0169555X15000331.

ZNAMESNSKY, D. Corridas de Detritos ou "Debris Flows": avaliação de parâmetros. 2001. Universidade de São Paulo, [S. l.], 2001.

ZUBRYCKY, S. Spatial impact trends on debris flows fans in southwestern British Columbia. 2020. University of British Columbia, [S. l.], 2020.

ZUBRYCKY, Sophia; MITCHELL, Andrew; MCDOUGALL, Scott; STROUTH, Alex; CLAGUE, John J.; MENOUNOS, Brian. Exploring new methods to analyse spatial impact distributions on debris-flow fans using data from south-western British Columbia. Earth Surface Processes and Landforms, [S. l.], n. April, p. 1-19, 2021. DOI: 10.1002/esp.5184. 